\title{
Snow in the Tropics
}


Thomas Taro Lennerfors and Peter Birch - 978-90-04-39386-8 Downloaded from Brill.com๑4/26/2023 03:03:15PM via free access 


\section{Snow in the Tropics}

A History of the Independent Reefer Operators

By

Thomas Taro Lennerfors

Peter Birch

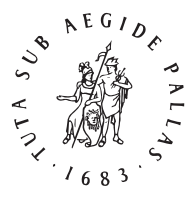

B R I L L

LEIDEN | BOSTON 
This is an open access title distributed under the terms of the prevailing CC-BY-NC

License at the time of publication, which permits any non-commercial use, distribution, and reproduction in any medium, provided no alterations are made and the original author(s) and source are credited.

This book is published with the support of the Swedish Society for Maritime History (Sjöhistoriska Samfundet) and the Sune Örtendahl Foundation. The book is Number 64 in the Forum navale series.

Cover illustration: The iconic Snow-class consisted of eight very large reefers constructed for Saléns between 1972 and 1974. They were fast and versatile and proved to be long-lived. Snow Crystal, later operated by Holy House Shipping, was the last of the Snow's to be sent to the breakers, in 2010. Antwerp, 2005. Photo: AlfvanBeem.

\section{Library of Congress Cataloging-in-Publication Data}

Names: Lennerfors, Thomas Taro, author. | Birch, Peter, 1970- author.

Title: Snow in the Tropics : a history of the independent reefer operators /

by Thomas Taro Lennerfors and Peter Birch.

Description: Leiden ; Boston : Brill, [2019] | Includes bibliographical

references and index.

Identifiers: LCCN 2018056526 (print) | LCCN 2019000099 (ebook) | ISBN 9789004393868 (ebook) | ISBN 9789004393769 (hardback : alk. paper)

Subjects: LCSH: Refrigerated transport--Tropics--History. | Shipping companies (Marine transportation)--Tropics.

Classification: LCC HE199.5.R432 (ebook) | LCC HE199.5.R432 L4 2019 (print) | DDC $387 \cdot 5 / 44-$ dc23

LC record available at https://lccn.loc.gov/2018056526

Typeface for the Latin, Greek, and Cyrillic scripts: "Brill”. See and download: brill.com/brill-typeface.

ISBN 978-90-04-39376-9 (hardback)

ISBN 978-90-04-39386-8 (e-book)

Copyright 2019 by Authors. Published by Koninklijke Brill NV, Leiden, The Netherlands. Koninklijke Brill NV incorporates the imprints Brill, Brill Hes \& De Graaf, Brill Nijhoff, Brill Rodopi, Brill Sense, Hotei Publishing, mentis Verlag, Verlag Ferdinand Schöningh and Wilhelm Fink Verlag. All rights reserved. No part of this publication may be reproduced, translated, stored in a retrieval system, or transmitted in any form or by any means, electronic, mechanical, photocopying, recording or otherwise, without prior written permission from the publisher.

Authorization to photocopy items for internal or personal use is granted by Koninklijke Brill NV provided that the appropriate fees are paid directly to The Copyright Clearance Center, 222 Rosewood Drive, Suite 910, Danvers, MA 01923, USA. Fees are subject to change.

This book is printed on acid-free paper and produced in a sustainable manner. 


\section{Contents}

Acknowledgements IX

List of Illustrations $\mathrm{X}$

List of Respondents XII

\section{PART 1}

\section{Introduction}

1 Tropics in the Snow: an Introduction 3

1 The Cold Chain 3

2 Maritime Reefer Shipping 4

3 Aim, Preliminary Research Question, and Potential Contributions 8

4 Independent Reefer Operators and Their Customers and Suppliers 10

5 Implications of the Industrial Landscape for the Study of Strategy 20

6 Three Theoretical Dimensions of Business Activity 22

7 The Structure of the Book 28

2 The Reefer Industry in a Historical Context 29

1 The Beginnings: Meat, Bananas and Fish 29

$21920 s, 1930$ s, and into the 1940 s 34

3 The 1950 and 1960 s 37

4 The 1970 s and 1980 s 40

$5 \quad$ 1990s to the Present 43

6 Summary 47

\section{PART 2}

\section{The Independent Reefer Operators}

3 Salénrederierna 51

1 A Fruitful Relationship 51

2 The Transatlantic Trade 55

3 The Route to Global Leadership 57

4 Salén Reefer Services on the Top of the World 61 
5 A Market Downturn and Some New Players on the Reefer Scene 64

6 Palletisation and Maximal Flexibility 66

7 Summary 70

4 Cool Carriers 72

1 Perfresh 76

2 Bilspedition as Owner: Ship Investments and the Golden gos that Never Came 80

3 Höegh and the Others: Broadened Market Presence with Limited Investments 86

4 Summary 94

5 J. Lauritzen 96

$1 \quad$ Mediterranean Adventures 96

2 Worldwide Growth 98

3 Rebuilding the Fleet after the Second World War 100

4 Lauritzen Peninsular Reefers 1970-1983: the Shark's Teeth 102

5 From Beautiful to Economical Ships: the Entry of the ULRCs 105

6 The Family Class and the Weak 1990s 107

7 LauritzenCool: Two Market Leaders Become One 112

8 Armada's New Reefer Venture $\quad 118$

9 Summary 120

6 Seatrade 122

1 The Management Buy-Out 125

2 Argentina and the Atlantic Fish Trade 128

3 The Newbuilding Programme 129

4 The Seatrade Pool 133

5 Dammers \& van der Heide 134

6 Integrating Dammers into Seatrade 137

7 Internationalizing the Operations 142

8 In the Turbulent Market of the New Millennium 145

9 New Partnerships: GreenSea Chartering and Joint Ventures 147

10 Newbuildings and Reefer-Containerships 149

11 Green Reefers 151

12 Summary 155 
$7 \quad$ Japanese Specialized Reefer Companies $\quad 156$

1 Japanese Fisheries 156

2 The Japanese Shipping Companies: NYK and the Others 166

3 Summary 174

8 From Blue Star Line to Star Reefers $\quad 176$

1 Entry into Specialized Reefers 179

2 Swan Reefer 184

3 Star Reefers 185

4 Summary 188

9 Laskaridis and the Hamburg Reefer Cluster 190

1 Hamburg Süd and the Hamburg Reefer Cluster 196

2 Summary 199

\section{PART 3}

\section{Container Lines and Shippers}

10 The Traditional Liner Companies and the Container Lines 203

1 Maersk 207

2 Summary 212

11 Fruit Companies and Marketing Boards 214

1 Chiquita 214

2 Dole 220

3 Del Monte 226

4 Marketing Boards 228

5 Summary 231

\section{PART 4}

Analysis and Conclusions

12 The Independent Reefer Operators from Material, Discursive, and

Subjective Perspectives 235

1 1950s: the Wild Reefers 237

2 1960s: Rationalizations and Explosive Growth 240

3 1970s: the Others 241 
4 1980s: Striving for Efficiency 243

5 1990s: We are Conventional! 245

6 200os: Decline and Consolidations 248

13 Snow in the Tropics: Conclusions 252

1 The Material Dimension $25^{2}$

2 The Discursive Dimension $\quad 25^{8}$

3 The Subjective Dimension 260

Bibliography 265

Index 270 


\section{Acknowledgements}

This project was financially supported by Sven och Dagmar Saléns Stiftelse and the Lauritzen Foundation. We are very grateful for this funding, without which it would have been impossible to complete the project.

We would also like to thank all respondents for their time and support. Meeting with you has been fascinating and truly rewarding! A special thank you to Ralph Mohlin.

Parts of the book were presented at two Work in Progress Seminars in 2013 and 2016 at the Division for Industrial Engineering and Management at Uppsala University. We are very grateful to the comments and additional perspectives that were provided.

We would also like to, once again, thank our families for their support, although they may not fully understand why we've become obsessed with reefers. 


\section{List of Illustrations}

\section{Figures}

$1 \quad$ Crown Topaz, Antwerp 2012. Photo by P. Birch 19

2 Dunedin. Painted by Frederick Tudgay 1875. Image source: Hocken Library. Public Domain 31

3 Fyffes Stockholm Exhibition 1930. Photo: Arkitektur- och designcentrum. Public Domain 35

4 Sigrid Matthiessen. Photo: Lindenborn, M./ Sjöhistoriska museet. Public Domain 54

5 Argonaut. Photo: Unknown/ Sjöhistoriska museet. Public Domain 58

6 Snow Storm, 1975. Photo: Magnussen, Friedrich / Stadtarchiv Kiel. Used in accordance with CC BY-SA 3.0 de 63

7 Malayan Victory. Photo: Östring, Bill/ Sjöhistoriska museet. Public Domain 69

8 Spring Deli. Photo: Garitzko. Public Domain 74

$9 \quad$ African Reefer, 1939. Photo: Unknown. Public Domain 99

10 Ecuadorian Reefer. Photo: Magnussen, Friedrich / Stadtarchiv Kiel. Used in accordance with: CC BY-SA 3.0 de 101

11 Ditlev Lauritzen. Photo: AlfvanBeem. Used in accordance with CCo 109

12 Maestro Reefers operate Jumbo-class vessels that had proven themselves with Lauritzen. Ice Rose, on time charter to Alaska Reefer Management, arriving in ballast in Dutch Harbour, Aleutian Islands 2012 to load frozen fish for East coast Canada and Europe 120

13 Arctic. Photo: Seatrade 124

14 Nautic. Photo: Seatrade 131

15 Majestic. Photo: Seatrade 132

16 Seatrade Orange. Photo: Seatrade Groningen. Used in accordance with Attribution-Share Alike 4.o International 150

17 Nagata Reefer. Photo: AlfvanBeem. Used in accordance with CCo 158

18 Ivory Dawn. Photo: AlfvanBeem. Used in accordance with CCo 172

19 Uruguay Star. Photo: Brown, W.H./ Sjöhistoriska museet. Public Domain 179

20 Star Endeavour. Photo: AlfvanBeem. Used in accordance with CCo 187

21 Holmfoss. Photo: Joost J Bakker. Used in accordance with CC2.o Generic 195

22 Kirsten Maersk. Photo: Maersk Line. Used in accordance with CC BY-SA 2.0211

23 Chiquita Deutschland. Photo: Tvabutzku1234. Used in accordance with CCo 219

24 Dole Honduras. Photo: Port of San Diego (Dale Frost). Used in accordance with CC2.o 223 


\section{Tables}

$1 \quad$ Salén's owned reefer fleet in $1968 \quad 61$

$2 \quad$ Newbuildings to Cool Carriers 1988-1992 82

3 Revenues, operating profit, book value of vessels and investment in vessels for Höegh's share of Cool Carriers 1994-200o 88

$4 \quad$ Unicool's owned fleet as of 31 December $1997 \quad 89$

5 Höegh's exit from the reefer segment 94

$6 \quad$ LPR's fleet in $1975 \quad 104$

7 The Jumbo vessels 106

8 LauritzenCool's fleet in 2003 (excluding ReeferShip) 115

9 Turnover of Lauritzen Reefers 118

10 Companies that are or have been pool members 134

11 Fleet in the Pool and/or Managed by Seatrade in $1991 \quad 139$

12 Seatrade Fleet List $2016 \quad 152$

13 World's largest container ship fleets (TEU) 205

14 Reefer capacity of the container lines 206

15 Fleet List for Dole Ocean Cargo in $2016 \quad 224$

\section{Graphs}

$1 \quad$ Indicative reefer spot rates mid 1990s $\quad 12$

2 Us banana imports 1961-2013 12

3 Russian banana imports 1994-2013 13

$4 \quad$ Reefer speeds 39

5 Total international reefer trade 41

6 Kiwi fruit exports from New Zealand 41

$7 \quad$ Grape exports from Chile $\quad 42$

8 Specialised reefer fleet capacity 45

$9 \quad$ Reefer cargo by volume (1993) 46

10 Reefer container capacity 46

$11 \quad 12$ months timecharter rates $\quad 48$

12 Salén reefer services turnover from 1968 to 1980 in MSEK 70

13 Cool carriers' organization 75

$14 \quad$ NYKs controlled reefer fleet 169 


\section{List of Respondents}

The following list includes the people who have contributed their time and knowledge to this book. With just a few exceptions they have been interviewed in person. The list of companies is not exhaustive and we also apologise if we've left someone out.

\begin{tabular}{|c|c|}
\hline Andersson, Mats & $\mathrm{B} \& \mathrm{~N}$ \\
\hline Ankarcrona, Henrik & Salén \\
\hline Aoki, Mr & NYK \\
\hline Arnhög, Mats & Caesar Reefers \\
\hline Åström, Bengt & Salén, Holy House \\
\hline Bergkvist, Göran & Götaverken, Bilspedition \\
\hline Börjesson Ruhne, Anna & Holy House \\
\hline Buitenwerf, Yntze & Seatrade \\
\hline Charlton, Nic B & P\&O, Lauritzen, Armada, Maestro \\
\hline Cheung, Alfred & OOCL \\
\hline Dahlberg, Carl-Otto & SOL \\
\hline Dunlop, Richard & Blue Star Line, Ocean Reefer \\
\hline Ebersson, Mathias & Cool Carriers \\
\hline Ellefsen, Mads & Seatrade \\
\hline Figenschou, Aage & Swan Reefer \\
\hline Fröjd, Ambjörn & Stena \\
\hline Gersling, Boris & Lauritzen, Cool Carriers \\
\hline Ghildiyal, Mukul & Cool Carriers \\
\hline Hägerstrand, Mikael & Cool Carriers \\
\hline Hammarberg, Göran & Johnson, Salén \\
\hline Hansen, Carsten & Lauritzen, Armada, Maestro \\
\hline Harr, Espen & Klaveness, Orion \\
\hline Hellberg, Svante & Salén, Cool Carriers \\
\hline Ihre, Rolf & Cool Carriers \\
\hline Ikeda, Mr & Nissui, East-West \\
\hline Jansen, Mark & Dammers, Seatrade \\
\hline Jansson, Mats & Salén, Cool Carriers \\
\hline Jonsson, Åke & Cool Carriers \\
\hline Kimura, Mr & Fresh Carriers \\
\hline
\end{tabular}


Ladegourdie, Malcolm

Larkin, Chris

Larsson, Lars Gunnar

Laurin, Hans

Lindberg Skov, Birger

Lindhardt, Henrik

Lindström, Bo

Lund, Mikael

Lundberg, Martin

Lyth, Peter

Marcussen, Peter

Mohlin, Ralph

Moors, Toby

Mossberg, Lars

Norén, Gösta

Ohno, Sadaya

Owesson, Per Olof

Patriksson, Folke

Pettersson, Tommy

Pinkham, John

Pladys, Peter

Ross, Kenneth

Rothschild, Peter

Rowland, John

Ruhne, Mats

Rutberg, Lars

Salén, Christer

Salén, Sven H.

Selling, Glenn

Shoji, Mr

Sjöstrand, Fredrik

Sjöström, Alison

Suzuki, Mr

Takeshige, $\mathrm{Mr}$

Tamiya, Mitch

Thomassen, Alv
Lauritzen, Cool Carriers

Africa Express Line

Cool Carriers, Seatrade

Salén

Lauritzen

Maersk

Salén

Lauritzen, Fresh Carriers

Bilspedition

Salén

Lauritzen, Armada, Maestro

Salén, Cool Carriers

Blue Star Line, Eastwind, Cool Carriers

Zenit

Cool Carriers, Seatrade

Toei Shipping

Salén, Cool Carriers

B\&N Nordsjöfrakt

Salén

Chiquita, Holy House, Diamond

Cool Carriers

Star Reefers

Salén, Cool Carriers

P\&O, Lauritzen, Cool Carriers

Salén, Cool Carriers, Holy House

NYK, Cool Carriers

Salén

Salén

Eastwind, Cool Carriers

KY

Cool Carriers

Cool Carriers

Fresh Carriers

Fresh Carriers

NYK

Klaveness, Orion 
van Overklift, Marnix

von Reiche, Joachim

Westling, Per

Wildöer, Walter

Wyatt, Tony

Zarkani, Shereen

Zielke, Wolfgang
Seatrade

Hamburg Süd, International reefers, ART

Stena

Seatrade

Ocean Reefer

Maersk

Hamburg Süd, International reefers, ART 
PART 1

\section{Introduction}


Thomas Taro Lennerfors and Peter Birch - 978-90-04-39386-8 Downloaded from Brill.com๑4/26/2023 03:03:15PM via free access 


\section{Tropics in the Snow: an Introduction}

The supermarket presents us with a cornucopia of fruit, fish, and meat from near and far. Usually we haven't thought too much about how it all got there and the fact that we can enjoy fruit from the tropics all year round is something that we usually take for granted. But we are constantly reminded of the perishability of these refrigerated and frozen foods. Bananas, for example, are easily bruised and we know that they will spoil in a matter of days if we don't hurry up and eat them. Although other fruits, such as apples or oranges, might be a bit more resilient, it's still only a matter of time. And it takes just one rotten apple to spoil the barrel as the saying goes. We know that we have to rush fish, meat, and dairy products into our fridge or freezer, particularly on a hot day. The threat of putrification is constantly there.

Considering this everyday, practical knowledge we have about the perishability and fragility of refrigerated and frozen products, it is remarkable that they have survived the journey to our supermarkets from far away production areas. Not the least because a lot of fruit is grown in tropical backwaters or at least needs to cross the equator in their journey from the Southern Hemisphere to the North. "Six foot, seven foot, eight foot bunch!" is a memorable line from the Jamaican working song Banana Boat Song (Day-O) made famous by Harry Belafonte. Bananas have often been harvested, loaded and transported under the heat of the sun and stowed onto ships in small ports lacking infrastructure. The ships themselves have to sail across vast oceans through hell and high water. It's therefore not surprising that in the past bananas and other perishables often arrived in port rotten. Since the first steps in the second half of the 19th century, the cold chain, in other words the long chain of events from plantation, pasture, or fishing ground, to the retail outlet, has developed and become more reliable and resilient. But still, the core of the cold chain is still the same - highly sensitive and perishable products, still requiring high quality handling. The aim of this book is to throw light on a particular link in this cold chain, but let's start by taking a broader perspective.

Bananas and other fruit that we discuss in this book typically originate from farms or plantations in South or Central America, South Africa, or New 
Zealand. Sometimes they are carried in a refrigerated state, or sometimes in a non-refrigerated state by means of trucks, or possibly trains to a port terminal. There, they are reloaded onto ships, with the capacity to carry refrigerated and frozen cargo, which transport the produce to the consumption areas. This reloading is done by stevedores. Often, the produce needs to be stored for a shorter or longer time in the terminals. This can be done in conventional, nonrefrigerated storage, or in refrigerated storage, so-called cold stores. The maritime link, when bananas travel from Central America to Europe or the Us, or from the Philippines to Japan, or when fruit is carried from South America or South Africa to Europe, or when frozen meat is carried from for example New Zealand and Australia to Europe, Asia, and the Middle East, is the central focus in this book. When reaching the consumption markets, the cargo is discharged and then reloaded by stevedores onto trains and trucks which carry the cargo to wholesalers and then to the supermarket. The final destination is usually your fridge or freezer, tropics in the snow if you will. The details of the cold chain described above may vary somewhat but the model more or less applies to all cargo types. For fish and meat, the whole chain needs to be cold, while for some fruits, this need not be the case. Fish is sometimes brought from the fishing grounds to a port terminal where it is reloaded onto ships which take them to the consumption markets, but sometimes it is reloaded on the very fishing grounds themselves. The latter is called transshipment and is a delicate procedure where two ships need to be close to each other, often in difficult weather conditions.

The historical development of the cold chain that has led us to be able to experience the cornucopia will be touched upon incidentally in the book, but as stated, the main aim is to explore the maritime link - maritime reefer shipping - and more particularly one specific actor in the maritime link.

\section{Maritime Reefer Shipping}

The maritime link, which is often the longest link in the whole cold chain, relies on ships that are equipped to carry refrigerated cargo. It also relies on companies or people who own those ships, and companies that actually run the shipping operation, making sure that the right ship is at the right place at the right time. For the moment, we will focus on the companies running the operation of the ships, to introduce three different actors. We will first describe the actors briefly, and then turn to the ships. 


\section{The Actors}

Maritime reefer shipping can be catered for by the liner industry, which consists of shipping companies mainly dedicated to non-refrigerated cargo but which have the capacity to carry refrigerated cargo on their ships. They sail with scheduled departures. Examples of liner companies, which appear in this book, are Blue Star Line and Maersk. A second actor which can cater for maritime reefer shipping is the shippers, in other words, the exporters and importers. They might own or charter a fleet of specialized reefer ships that are primarily dedicated to carry their own refrigerated or frozen products. Examples of such actors are the fruit producers Chiquita and Dole. A third actor is the independent reefer operator. They are not in-house logistics departments owned by shippers but rather third-party, independent companies, who do not carry their own cargo. In this way, they are similar to the liner companies, but with a focus on refrigerated cargo and their operations are only sometimes based on scheduled lines. They are free to say yes or no to any business offered by shippers and are never primarily dedicated to carrying the cargo of one shipper only. A crucial aspect is that the independent reefer operator actively competes for reefer cargo amongst a number of customers. Examples of important independent reefer operators are Salén's reefer division and, after its bankruptcy, the reconstructed Cool Carriers, which were market leaders from the 1950s until the 1990s, Lauritzen, which was the first independent reefer operator, and Seatrade, which is the market leader today. The latter two types of actors are specialized, meaning that they are primarily dedicated to carrying refrigerated cargo, their own or that of others. What unites the two latter actors is that they operate reefers. But what is a reefer?

\subsection{The Reefer}

As has been described, refrigerated and frozen products can be carried either on vessels that are mainly carrying general cargo, but with refrigerated cargo capacity, or ships specialized for carrying refrigerated or frozen cargo. In this book, we call the latter category reefers. But many readers have probably heard the problematic word reefer in various contexts and used in different ways. This word has created significant conceptual confusion, so in the following section we'll try to both problematize and tidy things up.

To start with, the word reefer is just an abbreviated way of saying refrigerator and it has been used over the years to refer to all sorts of refrigerated units from train cars to household refrigerators. However, in a maritime shipping context, it traditionally refers to a cargo ship with the capacity of carrying refrigerated cargo. 
Many of the early ships were multi-purpose, being able to carry general cargo, passengers, and some of their holds were insulated and could be refrigerated. These vessels are occasionally referred to as reefers, or part-reefers. However, in this book, we do not define these general cargo ships with some refrigerated capacity as reefers.

A term that sometimes crops up is the "freezer" which is a vessel capable of freezing, but not cooling, its entire cargo. These, usually smaller vessels, have been widely used to support the fishing industry, carrying the produce from sea to shore. These "freezers" are sometimes called reefers, and sometimes not. The earliest specialized reefers, back in the nineteenth century, were all freezers, yet they are usually referred to as reefers. The main point was that reefers could both cool and freeze their cargo, while freezers could only freeze their cargo. Some freezers were later rebuilt with more temperature control, which effectively enabled them to carry non-frozen cargo such as fruit, which turned them into reefers. In this book, we include freezers as a subset of reefers, but we still use the word freezers as a way to indicate this particular type of ship.

There were several material features that emerged during the twentieth century, besides refrigeration, which can be said to be typical of reefers. One of them was speed. Reefers were usually faster than regular cargo ships and the need to rush perishables to the market is understandable. Another feature relates to port access. Many small ports are not accessible to larger vessels, but it so happens that the refrigerated trades are particularly reliant on these. They can be tropical ports, small and undeveloped, but a tremendous source for bananas and other fruit. Reefers have also called on small fishing ports in the far north and on the southern tip of South America, as well as the Falklands. This effectively limits the size of reefers but also makes a shallow draft advantageous. A third feature is the priority placed upon the ship's own ability to handle cargo. Loading and unloading cargo breaks the cold chain, so reducing the time that perishable cargo spends between the port's cold storage facility and the reefer ship is important. Reefers are therefore well-equipped with their own derricks, and later on cranes, since infrastructure has usually been lacking in the small ports they call upon. It's also the case that major ports may experience delays that may be circumvented because of the reefer's own capacity in this regard. So to sum up, speed, smallish with a shallow draft, and wellequipped with derricks or cranes are features that are usually associated with reefers.

Until the early 1970s the reefer cargo was stowed and stacked in "breakbulk". This could be in nets, sacks, boxes, barrels etc. Banana stems were just stacked in the early days. However, since the 1970 s maritime reefer shipping increasingly moved towards the carriage of palletised cargo. These reefers were 
frequently termed pallet-friendly reefers or simply modern reefers in contrast to the old breakbulk reefers. Refrigerated containers began to make serious inroads into the refrigerated shipping market in the 1990s, and these containers are also referred to as reefers, but in this book we identify them as reefer containers. During these years it is common to read the phrase conventional reefer to mean a ship with refrigerated holds as distinct from a container ship carrying refrigerated containers. Occasionally, the reefer was also referred to as a bulk reefer. For many years a distinction was maintained between conventional reefers and the container ships (partly equipped to carry reefer containers) operated by the container lines. Reefers it was held, were not, by tradition more so than by any logical definition, container ships. This distinction became increasingly difficult to maintain, since the so-called conventional reefers were, with each successive newbuilding, equipped to carry increasing numbers of refrigerated containers. These vessels may be termed hybrid ships (refrigerated holds plus refrigerated containers) but at the time they were just considered reefers with high container capacity, sometimes they were, once again, labelled modern reefers.

Specialized container ships designed to primarily, or only, carry refrigerated containers began to appear in the years around 2000 and they were frequently termed reefer-container ships, but with time increasingly just reefers or reefer ships. Since we term any ship which is primarily dedicated to carrying refrigerated cargo a reefer, we also call these ships reefers. The latter term clarifies that it is the ship and not the reefer containers carried onboard that counts. In recent years the operators who controlled conventional reefers, have begun to use the term specialized reefers. So what at the present distinguishes the specialized reefer is not whether the cargo is stowed in containers or in a hold, but rather that the ship is primarily designed to carry refrigerated cargo directly and without delay to its destination. Interestingly, since the appearance of containerization, palletised reefers are sometimes called breakbulk reefers ${ }^{1}$.

So what is a reefer? As we've seen, exactly what is meant by the word, and how it has been used, has changed over time. After this conceptual exercise, we conclude that the best definition of a reefer ship is perhaps the simplest one: A ship specialised for transporting refrigerated cargo. We are back to where we started, but hopefully with a more nuanced understanding of this very central concept.

1 "Carriers put money on hybrid ship designs", Shanghai Shipping Exchange, 19 November 2012, $<$ http://en.sse.net.cn/info/detailen.jsp?id=310233>. 
After this brief introduction to the artefacts and actors involved in both the cold chain and maritime reefer shipping, it is possible to position this study. In this book, we focus on studying the independent reefer operators. Similar to independent tanker companies (not owned by either exporting oil companies nor importing companies), bulker companies, and liner companies, these independent reefer operators are unambiguously a part of the third-party commercial shipping industry for which shipping is not only a support function but the main business area. For this reason they should be as important to study as other third-party shipping companies, although the current scarcity of studies might be due to the discourse of decline and the fact that they employ less capital than for example tankers and bulkers. Since it is their core business, the study of the independent reefer operators is a direct way of studying maritime reefer shipping and, in a more indirect way, the cold chain.

Given its position as an intermediary between shippers and ship-owners, the independent reefer operators have a challenging position, having to please both these stakeholders as well as being profitable themselves. As Wijnolst and Waals ${ }^{2}$ indicate, there is a great discrepancy between ownership and operation in the reefer industry. Most of the independent operators' tonnage is owned by others, which means that the operators have a great market presence despite having a low degree of ownership - this precarious position is interesting to study from the perspective of business strategy. How do the independent reefer operators manage to stay in business and be profitable over time?

One should also note that there is a methodological reason behind studying the independent reefer operators - a question of access. Given previous studies, one of the authors had already discussed the reefer industry with representatives of Salén, Cool Carriers and Holy House. This preliminary study made it possible to get access to more respondents through the contacts that were made. Given that the study started with one independent reefer operator it was possible to get access to all reefer operators, but it was more difficult to get access to ship-owners, and even more difficult to get access to shippers. Also, the independent reefer operators are limited in numbers which also makes it possible to study them in a comprehensive way. The same cannot be said about shippers and ship-owners. For these reasons, we hold that the independent reefer operators are a suitable looking glass not only for reaching a deep understanding of this type of actor, but also to shed some light on the

2 Wijnolst, N. and Waals, F. 1999. Shipping Industry Structure, Delft: Delft University Press. Chapter 7, pp. 138-160. 
broader functioning of the cool trades, which could be explored in future research.

One can approach these operators both collectively and individually. Approaching them collectively means that one sees them as a set of companies which share some main characteristics, and are different than other sets of companies, such as liner companies. This approach would study how and why they emerged as an alternative to the liner companies, what led to their dominance in the carriage of refrigerated and frozen cargo, and their subsequent decline. Approaching them individually means that we can also recognize their particularity which is due to their different origins, resource bases, and strategies. Given the empirical material that we present in this book, the differences between the different companies are obvious and to neglect these differences would not give an accurate perspective of the development the independent reefer operators. An immersion in the empirical material has led us to focus on the strategies the various actors adopted, and how they tried to compete with each other and with the liner companies. We take a particular theoretical perspective when studying the independent reefer operators, which we will explain later in this introduction. But already here we can say that rather than conceiving the maritime link as just a logistical operation moving goods from A to B, we will study not only this material reality, but also the way the independent reefer operators make sense of themselves and the industry, and the psychological drivers for their business decisions.

Our research question in its simplest form is: How have the independent reefer operators developed, individually and collectively, since their beginning until today?

This book aims to contribute to business studies and maritime history by providing a historical analysis of the independent reefer operators. Such comprehensive studies have not been done before and given that the maritime transport of refrigerated products has been a well-defined niche in the shipping industry, it is important to describe it and shed light on its historical development. Furthermore, the book contributes by understanding and problematizing the workings of the industry by means of our three-dimensional theoretical framework - its material base with ships and cargoes, how actors within and outside the industry make sense of it by means of discourses/talk/language, and the psychology of the actors involved. This theoretical approach fits into current calls for more theoretical studies within the field of business history ${ }^{3}$. We believe that a deeper understanding of the independent

3 See for example de Jong, A., Higgins, D.M. and van Driel, H. 2015. Towards a new business history? Business History, 57: 5-29. 
reefer operators can also lead to insights into the driving forces of the shipping industry.

\section{4 Independent Reefer Operators and Their Customers and Suppliers}

Having specified the aims of our study, we will now give an overview of the actors involved in the maritime link and the various strategic choices they are confronted with. Many of the dynamics emerge through interactions between the independent operators and other actors, and it is therefore of importance to understand the context in which the independent reefer operators find themselves.

\subsection{The Shippers}

The independent reefer operators are embedded in a transport system, where shippers - in other words, those who want to transport cargo to the buyer, or those who want to transport cargo from the supplier - decide how to ship their goods, whether on their own ships, by means of short term contracts with shipping companies, or in some cases even outsourcing the whole shipping activity to shipping companies. While these actors are very important in the reefer industry, they are not covered as thoroughly, since our main purpose is to study the independent reefer operators - in other words, those actors who cater for the transport services of the shippers. These actors are often more or less independent from the shippers, in the sense that they are not owned by the shippers nor fully restrained by the desires and agendas of shippers. It should here be noted that if all shippers decided to organize their transport based on their own ships, there would no need for independent reefer operators. However, in the industry's history we have seen that in some phases shippers have wanted to own their fleets, in some phases they charter ships, and in some cases, they decide to collaborate with an independent reefer operator or a liner company to ensure a cost-effective and secure transport system. And of course, combinations of these different choices.

It is generally the demands of the shippers and the buyers which decide how much maritime shipping capacity is needed in the industry. The major categories of refrigerated goods to be transported across the ocean have been quite stable during the era of the independent reefer operators which tentatively started in the 1930s. As will be explained in chapter 2, the reefer industry as a whole started with meat and was followed by bananas, other fruit, and fish. These different cargo categories have their own inherent dynamics. Bananas have been the absolutely most important reefer transport commodity during 
the era of the independent reefer operators, occupying approximately $40 \%$ of transported volumes ${ }^{4}$. Apart from volumes, for the shipper to understand how much tonnage is needed, there is also a need to know the distances the produce is transported. For example, a round-trip that last twice as many days with the same amount of cargo will require twice as much tonnage. We can illustrate this perhaps easiest by considering the following example. A large trade takes place with bananas from the Philippines to Japan since the 196os. Failed harvests in Philippines, due to bad weather for example, means that Japan might source its bananas that year from Ecuador. The result is that the shipper needs more shipping capacity during that year.

Bananas are produced throughout the year but most other fruits, for example apples, grapes, citrus and kiwifruit, are seasonal. When such fruit ripens in the Southern Hemisphere, it needs to be transported to the major consumption markets in the Northern Hemisphere. These seasonal volumes are usually fixed by short-term time-charters and any excess is picked up by the spot trade. For the shippers, the spot trade acts as a kind of reserve shipping capacity. Shippers are reluctant to contract their entire anticipated requirements since inclement weather, for example, can destroy the harvest. A bumper crop on the other hand, means that there will be a shortage of shipping which will in turn lead to high spot rates. Graph 1 shows the average spot rates in the mid 1990 f for the purpose of showing the significant variation of rates throughout the year with high demand, and thus high rates, in March and April. This seasonal variation is what allowed some operators of old tonnage to sail in the peak months and then have their vessels in lay-up during the off-season. It can be estimated that the transport demand in the high season can be between $5^{0-}$ $80 \%$ higher than in the low season ${ }^{5}$.

So, the demand for ships is determined by the volumes as well as the distance between production sites and consumption markets. The demand for imported refrigerated goods is related to consumer purchasing ability which is in turn influenced by both the availability of supply (i.e. pricing) and the effects of economic recessions and periods of prosperity. Demand can also be stimulated or otherwise by social factors: health consciousness, fashion and marketing initiatives.

Major reefer fruit trades include the banana trades from South and Central America to the USA (see Graph 2) and to Europe in particular. Bananas from the Philippines are important as are New Zealand's apple and kiwi exports. Grapes from Chile and South Africa, citrus from for example Morocco, Israel

4 "Kylsjöfart". Svensk Sjöfarts Tidning 1993/50, pp. 72-74.

5 "Kylsjöfart". Svensk Sjöfarts Tidning 1993/50, pp. 72-74. 


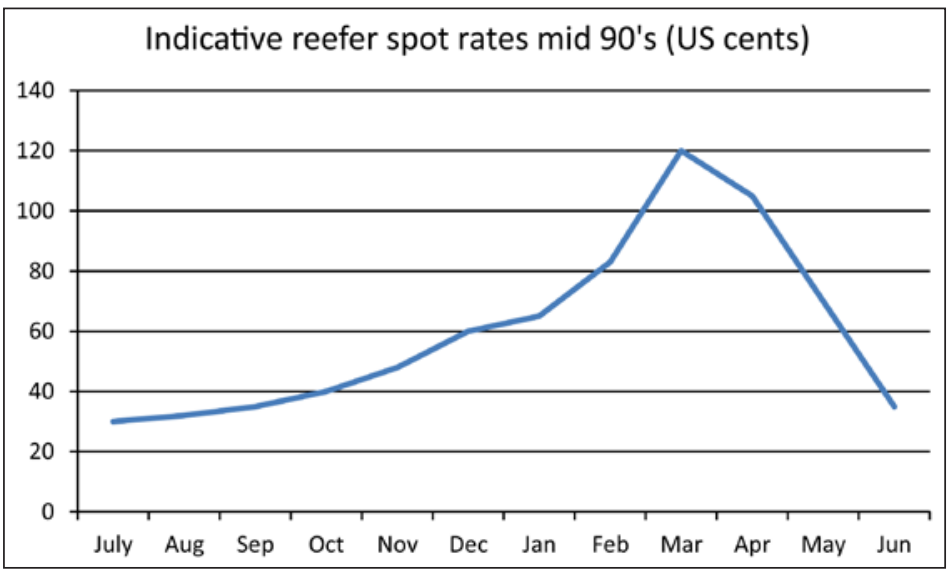

GRAPH 1 Indicative reefer spot rates mid 1990 (Us cents)

Note: Lauritzen Cool in Perspective, 2003.

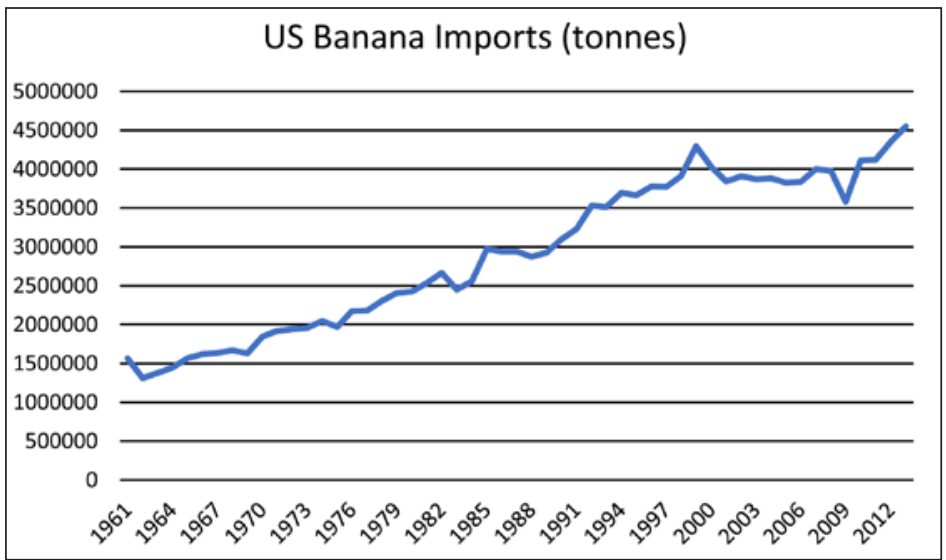

GRAPH 2 US banana imports 1961-2013. Transporting bananas to the USA is a major business for maritime reefer operators, only the banana trade to the European Union is larger.

Note: (c) FAO, Food and Agriculture Organization of the United Nations <http://www.fao.org/faostat/en/\#data/TM>

and other places and our list of important trades could include pineapples, melons and tomatoes and so on. And in most cases the destination has historically been the us, Europe or Japan. These major consumption centres are also important destinations for fish and squid which can come from places such as the South Atlantic. The meat trades from Argentina and Australia to originally 


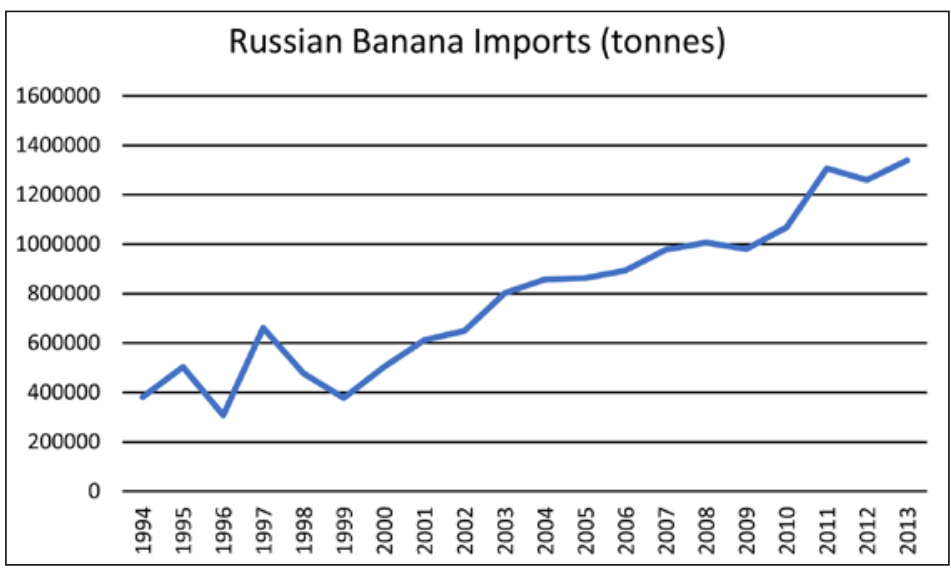

GRAPH 3 Russian banana imports (tonnes) 1994-2013. Russia's banana imports have increased significantly since the late 1990 . Note: (c) FAO, Food and Agriculture Organization of the United Nations <http://www.fao.org/faostat/en/\#data/TP>.

Europe and later the USA are large and these trades were early to be containerized. The demands of the consumption markets have changed during the studied period. For example, after the collapse of the Soviet Union more fruit, fish and meat were imported into Russia and other Eastern European countries. Russia has become a large banana importer in recent years (see Graph 3), particularly from Ecuador.

Also, the development of China the last two decades has had an impact on the market. Furthermore, one can see the growing importance of supermarket chains, with the likes of Walmart and Tesco having significant buying power. Moreover, there have been significant regulatory changes, first in terms of the deregulation of import and export markets, hand in hand with the penetration of economic liberalism throughout the world. Import and export boards have been replaced by a more free-market structure. This has altered the environment in which independent reefer operators act.

The strategic choices of shippers depend on what kind of shipper they are. Some shippers in the meat trade have during some periods had an entire integrated value chain, owning everything from cattle, abattoirs, cold stores, ships, and retail outlets. Banana majors have the possibility to either own their ships, charter ships from an independent ship-owner or let an independent operator do the job. Often they choose a combination. As we will describe in the following, the shipper might consider that transport is or is not a core business worth to invest money in. A main question for the shipper is whether the money 
employed when buying and owning ships is adequately invested. Maybe one should rather aim at improving plantations and acquiring more fertile land? But how can one ensure that the independent reefer operators will do their job? Sometimes strategic partnerships are formed between shipper and operator. When it comes to shippers of other fruit, due to their seasonality, it is less likely that the shippers will buy their own tonnage. Rather, as has been described, they employ ships on time-charters and on the spot market. A strategic decision here becomes how much tonnage should be time-chartered, what tonnage, and from whom. The shipper of course wants to see the cargo arrive in good condition without delays. Failure to do so will lead to various kinds of discussions and settlement between the shipper and the ship-owner and/or operator.

The shippers pay the operators or ship-owners on the basis of the transport capacity of the ship and also the potential of other alternatives. The transport capacity includes the carrying capacity of the ship, the speed (since a faster ship can transport more volumes in a give time period), the bunker consumption (a highly fuel consuming ship leads to more costs), the cargo handling equipment (since it affects the time in port), and other extras. The sine qua non is of course that the ship should be able to carry the produce of the shipper. Freezers might not be able to carry bananas, and so on. An extra bonus can be paid for going to far-off or more inaccessible areas.

The shippers also pay the operators and ship-owners on the basis of available alternatives, such as carrying the cargo on competitors' ships, and on liner vessels or container lines. Sometimes a lower rate can be perfectly fine for a ship-owner that owns old, depreciated ships. And sometimes the shipper, given the alternatives of a cost-competitive liner service, cannot or will not pay a significantly higher rate for transporting cargo in a reefer. A premium over the low-cost alternative by a certain percentage might be acceptable.

Since shippers do not own all the means to take care of their maritime shipping needs, there is a reefer shipping industry, which consists of a few major kinds of players.

\subsection{The Ship-Owners}

Ship-owners invest in a ship using equity, loans and/or other forms of financing. The investment can either be done on speculation (without a clear customer in mind) or based on a customer's particular requirement. To secure a long time-charter is often a requirement from the ship-owner in order to build a new ship. Therefore, the banana companies with their stable and non-seasonal trade are excellent business partners for a ship-owner who wants to construct new vessels. 
After the ship is owned it is either chartered to a shipper or time-chartered to or allowed to be used in a profit sharing scheme by an independent reefer operator. A ship-owner can have various motives for owning ships. Ships can be used as a way to generate profits through their everyday operation, and then it is important that the income exceeds operational and capital expenditure. They can also be primarily aimed at the increase of ship value, for example that the ship is bought before the market goes up and sold when the market has risen. A ship can also be used as an investment which allows the main owner or related co-owners to reduce their tax burden. A merchant ship is a major investment and yearly depreciations can dramatically cut the tax burden of other businesses.

Sometimes the ship-owners are highly knowledgeable about shipping, but sometimes they see the ships as pure financial investments and rely to a greater extent on the judgment of the independent reefer operator or shipper. What are then the strategic options available to a ship-owner? It is to decide if one should own ships, if more ships should be bought, or if ships should be sold. Strategic choices can also concern how the ships should be maintained - how much money should be spent on maintenance and what crews are suitable? Here there are questions of short-term or long-term cost, quality, and longevity of the ship that are central. Given the different motivations of the ship-owners, it could be the case that a ship-owner buying ships for speculative ends might be less interested in excellent maintenance for the longevity of the ship, but it is not certain. The maintenance could be done in-house or by independent ship management companies, thus allowing the ship-owner to strike the balance between in-house full control and dedication (but also being tied up with costs) and outsourced operations, where there is often access to more competence, but where the ship-owner is one amongst many.

The ship-owner must also choose where to flag the ship. Depending on which flag state a ship-owner chooses, the ship can be employed in different trades and are subject to different regulations when it comes to manning, technical controls, etc. Most ship-owners have during the century which is the focus of this book moved away from national flags to flags of convenience, meaning flag states where the demands on crewing and technical maintenance is lower, and states where the tax regime is beneficial ${ }^{6}$. Flag states regulate various aspects connected to running ships and sometimes there are also

6 Carlisle, R. 1981. Sovereignty for Sale: The Origins and Evolution of the Panamanian and Liberian Flags of Convenience, Maryland: Annapolis. De Sombre, E.R. 2006. Flagging Standards: Globalization and Environmental, Safety, and Labor Regulations at Sea, Massachusetts \& London: Cambridge. 
international consequences. For example, reefers flagged to certain states could not be employed in the squid trade during the Falkland Islands conflict. Many ship-owners in the 1930s transferred their vessels to the flags of countries that it was assumed would be untouched by the upcoming war. Avoiding wartime confiscation was one of the reasons for the emergence of flags of convenience, another reason was to bypass the prohibition of alcohol in the USA after 1922. Moving on from flagging, it is worth noting in this context that political actions, such as trade embargoes, impact on shipping. For example, Russia has reduced its imports of frozen poultry from the USA during times of poor political relations. This has immediately affected the market and for carriers of frozen cargo it's been anything but good news. Trade embargoes of particular products or against particular countries impact on shipping. Vessels that have called on Israeli ports have sometimes not been welcome in certain places.

When it comes to commercial operation, the ship-owner can commercially employ the ship in-house. But as we have mentioned, there are other options. A time-charter agreement with a shipper or an independent reefer operator is a common choice. The shipper or operator thus agrees to pay the ship-owner a rent to be allowed to use the ship in their operations. There can be timecharter agreements ranging from weeks to years. The profitability of the ship-owners' business becomes quite predictable, since the ship-owner more or less knows the income and the cost of owning the ship. Several risks remain, for example, technical breakdown or the risk that time-charter agreements will not be prolonged, or that they will be cancelled. If time-charter business is the main business of the ship-owner, there is often no need for a large commercial function. However, the time-charter rate is a negotiated price which is often a win-win situation for several parties, meaning that the ship-owner could potentially reap even more profits if she decides to operate the ship herself. For example, a time-charter rate might be based on the shipper's assumption that the ship will sail with no cargo back across the Atlantic. But if the ship-owner knows that there is indeed a profitable return cargo that will not delay the ship significantly, the ship-owner might see even more potential for profit. Then, she could decide to operate the ship herself. One option is to operate the ship on the spot market. When a cargo is available, the ship-owner has a potential to transport it by offering the best price and conditions. However, some shipping markets have a more developed spot market than others (for example crude oil transport). It is widely considered that the reefer market is not and has never been one of them. This could lead to significant risk for the ship-owner that the ship will be unemployed, generating cost but not income.

Another possibility is to have contracts of affreightment, which means that the ship-owner binds herself to doing a number of voyages for a shipper during 
a specified time period. During the time when the ships are not employed by the shipper, the ship-owner has the opportunity to use the ships in whatever way she deems fit. This is, in a sense, a middle ground between the time-charter and the spot market. The ship-owner can also offer the ship to an independent reefer operator. The operator often has a large number of ships and the ship-owner gets a share in the profits from all the ships. This share corresponds to the size, speed, age, etc. of the ship. For the ship-owner, the independent reefer operator works according to best effort, and can therefore render larger profits than a time-charter agreement. Also, since the market risk is shared with other ships, there is often a minimal earning that is higher than the worst calamity on the spot market. So, for the ship-owner, the decision whether to employ the ship on time-charters, contracts of affreightment, the spot market, or with an independent reefer operator is dependent on several factors. Timecharter requires less work and leads to a stable income during a time period. Contracts of affreightment leads to stable income for some consecutive journeys and the possibility of extra profits from the time in-between. However, it requires more work and pesonnel in order to find the cargo to transport. The spot market requires even more management and expertise but has the potential to reap even higher profits, if the spot market in the particular shipping industry is healthy.

\subsection{The Independent Reefer Operators}

The central actor for this study is the independent reefer operator. The operator is an intermediary, or middle-man, between shippers and ship-owners, using the ship-owners to secure ships and marketing these ships to the shippers, alternatively securing a contract with a shipper and securing ships with a shipowner. In a sense, the operator takes on market risk and gets the chance to reap profits. We have seen that ship-owners can also market ships to customers, but a main importance is that an operator markets the tonnage of various shipowners. The operator itself can also be a ship-owner, but only if it markets other tonnage as well, do we classify it as an operator. Wijnolst and Waals give a comprehensive description of the reefer industry until $1995^{7}$. Apart from surveying the state of the art of the reefer market, they pay explicit attention to the ownership structure of the industry, noting that the biggest owner in 1995, Seatrade was owning a mere $3.5 \%$ of the world reefer fleet. The authors also pointed out how reefer ships are arranged in different pools that have a larger market share than is visible in the ownership numbers. According to Wijnolst

7 Wijnolst and Waals 1999, pp. 138-16o. 
and Waals the more detailed analysis of such operators is left undone, which is a reason why we attempt such an analysis in this book.

There are mainly two ways for the operator to secure a ship. The operator can either timecharter ships from a ship-owner, or they can convince the shipowner to let the operator employ the vessel to take a share of the income of the operator (without any promises of a rate). It is of course assumed that the income is greater than if the ship-owner would have employed the vessel by herself or charter it to a shipper. If the ship is timechartered the operator pays a monthly rate to the ship-owner, which makes it possible to earn but also lose money if the differential between the market level and the timecharter rate is significant. Also, the independent operator can own ships. The line between a ship-owner and an operator is not fixed. We will see periods in time, where ship-owners become operators and vice-versa. Sometimes we will describe how much external tonnage an operator controls to get a glimpse into to what extent they are a traditional ship-owner and to what extent they are an independent operator.

The operators have the shippers as customers and sign short-term or longterm contracts of affreightment or time-charter contracts with the shippers. Some specific ships might be fixed, or employed, with a shipper. Other ships can be arranged in a so-called pool. In this pool, all constituent ships share the revenues from the pool. The ships share the revenues not equally but depending on the ships' capacity, speed, consumption, age, cargo handling equipment, and other potentially relevant factors. When many ship-owners collaborate, issues of fairness will constantly crop up, and it is important that ship-owners perceive there to be fairness. An operator can have different pools, similar to a market segmentation. For example, small ships suitable for fish trades can be in one pool, while larger ships suitable for fruit transport might be in another pool.

Independent reefer operators usually control more ships than ship-owners do and this is why they are able to secure higher proftablity. They can optimize transport patterns. For example, in the periods in which a ship is not needed by a shipper, the operator can employ the ship in other trades needed by other customers. The operator also has constant contact with several market channels and in general has more insight into the market than do single ship-owners. Also, since at least theoretically, any ship in the pool can take a particular cargo, the independent operator will always have ships closer to the customer due to their market scope.

An illustration of how to increase the utilization of vessels follows. An operator has been given the contract to take squid from the Falkland Islands to Japan. Finding suitable backhaul cargo on the return leg to the Falklands may 


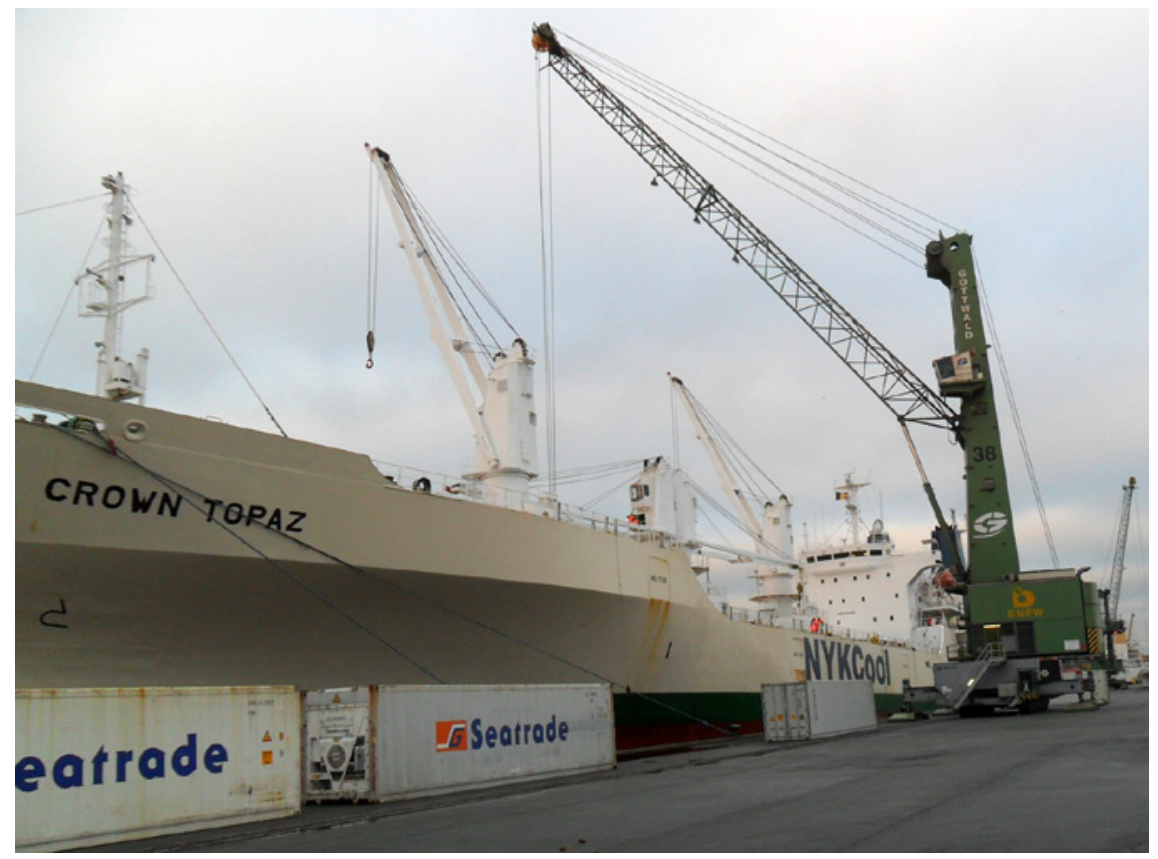

FIGURE 1 Finding backhaul cargo and repositioning empty reefer containers are two problems facing operators. Pictured is an NYKCool reefer loading its competitor's empty containers as backhaul cargo to the Caribbean. Antwerp, 2014 PHOTO: P. BIRCH (AUTHOR)

be impossible, although some reefers with large fuel tanks have transported bunkers there. But, perhaps second-hand Japanese cars can be carried to Buenos Aires or maybe to Valparaiso. The reefer operator could offer a low rate for this transport, as the alternative would be to sail empty.

The role of the independent operator is often quite precarious. There is the constant risk of ship-owners thinking that they can do better themselves, or with another operator. Much of the success of the independent reefer operators is built on that the ship-owners believe that they are maximising their revenue. The independent reefer operators therefore need to keep the shipowners loyal, both by actual revenue, and by expectations of large revenues in the future.

An operator is often a big actor that has direct relations to major customers. Sometimes operators want to integrate across the value chain and offer doorto-door services. In other words, that the produce is picked up with trucks, transported by ship and then with train and truck again until reaching the final destination with all transports arranged by the reefer operator. With such 
strategic decisions, the operator can solve the customer's problems, but it also requires the necessary personnel and administrative skills to handle the relations to various actors in the supply chain. When venturing into land transport, new competences are needed, which the company might or might not have.

We have also mentioned the development of transport of reefer cargo with large container lines. These companies, such as Maersk and MSC, can also be conceived of as operators who offer transport services to shippers. The distinction between the container lines and specialized reefer operators is that reefer operators are usually shipping the cargo faster and more directly in purposebuilt ships, while container lines carry different kinds of containerized cargo in a logistical network. A frequent discourse in the reefer business is that independent reefer operators offer a taxi service, while container lines provide a bus service. We can therefore see that operators need to make strategic decisions when it comes to what service they are offering, in terms of price, time to market, quality, etc.

\subsection{Brokers}

Another kind of company is the broker, which connects different actors in the industry. Brokers can help operators to find shippers and help shippers to find ship-owners or even operators (although they are quite well-known). There are also sales and purchase brokers, helping ship-owners to find good appropriate ships to buy, and newbuilding brokers, who are middle-men between shipyards and ship-owners.

We have now described some main actors in the specialized reefer industry, but it must be emphasised that the same company can belong to different categories. It is possible that an operator is also a ship-owner, or vice versa, and that a shipper primarily operates its ships on the international competitive market (outside the transport needs of the shipper itself). Furthermore, another consequence of this situation is that the independent reefer operators are indeed dependent, in the sense that they are always part of an industrial network. When we study their strategies, we are well aware that their freedom to act and formulate strategies is very dependent on the network they are part of. Even though we study the independent reefer operators, it is likely that sometimes their strategies have been highly influenced by other actors, for example their customers. Actors have historically played different roles and had shifting power relations. Therefore, in our study, incidentally, we problematize the 
locus of strategy - the power to act and influence a company's own development as well as the direction of the industry.

Corporate actors are often seen as the main locus of strategy, but it is important to note that they cannot make decisions. People make decisions, for example as individuals, or as groups and networks of various kinds. In the study, we will shift our view between various actors and their strategic choices, in order to problematize the locus of agency that is sometimes assumed to be the top management in organizations. In our study, we will show that it is sometimes the customers, sometimes a community of employees, sometimes the owners, and indeed sometimes the top management who shape strategy. We will therefore argue that there is an intricate web of actors and decisions that together has shaped the development of the independent reefer operators.

Although we are interested in being close to the empirical material in this book, we are aware that much has been written about strategy, also in the shipping industry, and it is helpful to survey the various strategic options that actors can choose. Researchers Niemié and Germain ${ }^{8}$ describe earlier research on shipping strategy stating that shipping companies can engage in differentiation - meaning that they do things differently from the competition, thereby creating a value proposition that is attractive to the customers. Rather than just moving goods from A to B, shipping companies can add terminal operation, warehousing, increased geographic coverage, added frequence or directness of sailings, and so on. By doing this the shipping company can charge a price over the market price. Some smaller players might adopt the strategy of concentration, or in the Michael Porter's words focus, where they focus on a specific geographic segment, or other kind of niche of a shipping market. Defining what constitutes a niche is of course debatable. Something is always a niche in relation to something else, and there can be niches within niches. For example, reefer shipping can be considered a niche within the broader shipping industry. Focusing on time-chartering vessels to major banana companies would then be a niche within the niche. Shipping companies can also adopt a strategy of cost leadership - being the cheapest company to offer the service. This could be achieved by having an older fleet, for example, with ships that are already amortized.

Niemié and Germain connect the shipping literature to Igor Ansoff's strategy of diversification, which means that a shipping company manages risk by not putting all eggs in one basket. The company can invest in other maritime sectors than the one they are operating in, or in non-maritime sectors, such as

8 Niemié, O. and Germain, O. 2014. Strategies in Shipping Industry. A Review of "Strategic Management" Papers in Academic Journals, Working paper, ESG/UQAM. 
real estate or finance. However, strategic choices do not always fit neatly into these frameworks. Companies can choose to collaborate with customers, suppliers, or even competitors, in order to increase the competitiveness of the company. Similar literature sees networks and business relationships as a crucial aspect for strategy 9 .

Niemié and Germain's study concludes that much of the strategic literature on shipping is outdated theoretically. It remains quite rationalistic, in that companies are assumed to formulate their policies after having done a rational assessment of the situation. It also excludes novel theoretical discussions in the broader field of strategy, for example sense-making perspectives, which highlights how strategies are formulated with reference to many more aspects than the so-called (material) reality, for example stories, myths, collective (mis-)perceptions. In this study we use a theoretical framework that hopefully goes beyond the often-used theories of Porter and Ansoff, and thereby throws additional light on what shipping companies are doing and why. It is to this framework we now turn.

\section{Three Theoretical Dimensions of Business Activity}

We present three dimensions that are important for the study of businesses or industries: the material, the discursive, and the subjective. This is a framework that was developed by the philosopher Alain Badiou and utilized in business studies to study the shipping companies Stena Bulk and Concordia Maritime ${ }^{10}$. In that study, it was argued that the promotion of a particular concept of "quality" was carried out both through discourses (such as "oil should always travel first class") and symbolism, such as the visual representation of ships. This had an impact on how quality was framed within the oil shipping industry. Although this can be dismissed as just irrelevant "talk" and "images", it had a real impact on material dimensions, such as scrapping rates.

9 Håkansson, H. and Snehota, I. 1989. No business is an island: The network concept of business strategy. Scandinavian Journal of Management, 5: 187-200. Håkansson, H. \& Snehota, I (eds.). 1995. Developing relationships in business networks. London: Routledge.

10 Lennerfors, T.T. 2013. Att skapa en värld - Stena Bulk, Concordia Maritime och marknadsföringens betydelse i tanksjöfarten 1982-2012, Gothenburg: Breakwater Publishing in collaboration with BAs. Other studies that use a discursive approach are Forsberg, P. 2001. Berättelser och omdömen i en redares vardag, Göteborg: BAS. Guy, E. 2013. Representations and policy change: evidence from the Canadian-flag shipping industry. Environment and Planning A, 45: 1184-1198. 
Our reason for dividing reality into these three particular dimensions is because we hold that they provide a novel and productive reading of the independent reefer operators. The main distinction from established analytical frameworks is that the utilized framework highlights the role of discourses, language, sensemaking, as well as the psychological drivers behind the development of this industry.

The subjective dimension was later updated based on more recent work by Badiou to encompass Plato's concepts of eros, thymos, logos, which will be explained below ${ }^{11}$. The present book connects these two triads and develops them further and is therefore part of the explorative project of utilizing philosophy to understand an industry.

Many industrial studies have focused on either the material dimensions, for example the size of markets, or availability of capital. Other studies have spotlighted the individual traits of a particular entrepreneur. Business studies have also followed the discursive turn in social sciences to understand underlying structures of sense-making in organizations. However, this study encompasses all of these perspectives. The advantages of combining these dimensions is that we can see how these dimensions interact with each other. This gives, we believe, a richer and also a more accurate and nuanced presentation of an industry. However, the increased complexity makes it an approach that lends itself more to understanding rather than the clear-cut conclusions that can follow from the application of simplified models.

\subsection{The Material}

The first is the material, physical, dimension. Here we claim, unsurprisingly, that it is of importance to understand the cargoes, the ships, cargo handling techniques, the geographies of export and import markets, and the people involved in the industry. Related to mainstream business strategy literature, the most direct connection is to the concept of resources. For example, the Resource Dependency Theory states that an organisation is an open system that interacts with its environment and is dependent upon resources in that environment ${ }^{12}$. To understand a reefer company, one must understand the company's access to financial resources, ships, and knowledgeable people. The

11 Badiou, A. 2005. Being and Event, New York: Continuum. Badiou, A. 2009a. Logics of Worlds, London: Continuum. Badiou, A. 20ogb. Theory of the Subject, London: Continuum. Lennerfors, T.T. 2015. Eros, thymos, logos: A study of the spirit of entrepreneurship and innovation at Stena, Gothenburg: BAS. dence perspective, New York: Harper \& Row. Pfeffer, J. 1976. Beyond management and the worker: The institutional function of management. Academy of Management Review, 1: 
Resource Based View (RBV) describes that companies can achieve sustained profitability, by having resources that are valuable, rare, inimitable and nonsubstitutable (VRIN) ${ }^{13}$. Recent RBV studies investigate how resources are combined with other resources to create profitability ${ }^{14}$. RBV has recently started to discuss non-firm resources and how they contribute to a firm's success ${ }^{15}$. Resources are connected and there is interaction between them. The Resource Interaction view ${ }^{16}$ describes how companies have long-standing relationships to other companies. In this theory, one cannot say that a resource in itself is valuable, rare, inimitable and nonsubstitutable, but one must consider the interaction between resources in industrial networks ${ }^{17}$. This view is particularly interesting in the reefer industry which abounds with alliances, clusters, and long-term customer relationships.

To focus on the material dimension means not just to see the material reality as separate artifacts, but rather to conceive of the world as a network of interconnected people and artifacts. These networks can form stable patterns, for example a transport system consisting of trucking bananas to the port, repacking them in pallets, loading them by crane, transporting them across the ocean, and discharging them at the destination.

What we exclude when we single out the material dimensions is the sensemaking, the discourses around this material phenomenon, and the thoughts, desires, and affects concerning this material reality. However, discourses as well as the subjective dimension influence material reality. For example, a

36-46. Hillman, A.J., Withers, M.C. and Collins, B.J. 2009. Resource Dependence Theory: A Review, Journal of Management, 35: 1404-1427.

13 Penrose, E. 1959. The theory of the growth of the firm, New York: John Wiley \& Sons. Barney, J. 1986. Strategic factor markets: Expectations, luck and business strategy. Management science, 32: 1231-1241. Barney, J. 1991. Firm resources and sustained competitive advantage, Journal of management, 17: 99-120.

Kalling, T. 1999. Gaining competitive advantage through information technology - A resource-based approach to the creation and employment of strategic IT resources. Lund: Institutet för ekonomisk forskning, Lunds universitet. Priem, R. \& Butler, J. 2001. Is the resource-based "view" a useful perspective for strategic management research? Academy of management review, 26: 22-40. Kraaijenbrink, J., Spender, J-C. \& Groen, A. 2010. A resource-based view: A review of and assessment of its critiques. Journal of management it, 36: 349-372, Jansson, C. 2012. Företag med framgång: hur resurser kan skapa varaktiga konkurrensfördelar, Göteborg: BAS.

Lavie, D. 2006. The competitive advantage of interconnected firms: an extension of the resource-based view. Academy of Management Review, 31: 638-58.

Håkansson, H. \& Waluszewski, A. 2002. Managing technological development - IKEA, the environment and technology, London: Routledge. Baraldi, E., Gressetvold, E., and Harrison, D. 2012. Resource interaction in inter-organizational networks: Foundations, comparison, and a research agenda, Journal of Business Research 65: 266-276. 
discourse about the importance of high quality, will lead to a focus on changes in the material dimension, for example, the design of cargo holds, cargo gear and hull shape.

People's actions and the result of them are also part of the material dimension. This can concern the habits of loading bananas onto a ship, but also the everyday, habitual work of fixing cargoes in commercial operations. Once again, the focus is on the material and not on the discourses and the subjective attitude of the participants in the practices. This focus on the networks of artifacts and people connects to a few recent streams of thought in business studies. One is actor-network theory, which similarly to our material dimension, does not distinguish between artifacts and people. Both kinds of matter are connected in networked relationships, which directs the development of both actors and networks. Also, it connects to strategy as practice ${ }^{18}$, which to some extent reduces the subjective dimension in strategic work - in other words, rather than claiming that strategies are formed by means of rational, cognitive processes, they claim that material practices (as well as discourses) can significantly influence what strategic actions are taken.

In our description of the various reefer companies we will describe how they have evolved in the material dimensions: what ships they have bought or sold, innovations in ship design or cargo handling, recruitment of people, where the companies are physically located, the logistical systems of which they are part, and so on.

\subsection{The Discursive}

A second dimension is the discursive, which means how we describe, discuss, make sense of, and represent reality. People in a company can for example discursively make sense of the company as an "intuitive" or fast one, alternatively as a company where decision-making processes take a long time. This is certainly related to the material dimension, that a company is really fast or slow, but sometimes the discourses do not correspond to the material reality. Perhaps they once did. Sometimes they also contribute to changing the material. We maintain that it is important to highlight the discursive dimension, and its inclusion into the framework is a reason for why the framework is productive. While other approaches might focus on the real, economic forces in an industry, we hold that language, discourses, sense-making are equally important for the development of an industry. The approach that we have

18 Jarzabkowski, P. 2004. Strategy as Practice: Recursiveness, Adaptation, and Practices-inUse, Organization Studies, 25: 529-560. Whittington, R. 2006. Completing the Practice Turn in Organization Studies, Organization Studies, 27: 613-634. 
outlined here is similar to approaches in organization studies which have been prevalent since the 1980s, positing that constructed perspectives are crucial for understanding organizations ${ }^{19}$. Very broadly conceived, such studies state that the way we make sense of a situation is very important in how we decide to act upon the situation.

For example, industry reports about the reefer industry are fundamentally discursive. The material reality of fleet sizes, capacity, market rates, and so on are framed by discursive processes of inclusion and exclusion. For example, the segment of smaller reefer ships is frequently excluded from market data. A study which is solely based on market data thus becomes limited due to the discursively constructed nature of the so-called objective material reality. Speed is sometimes measured at "banana draught". In other words, much of the attributes of the material artifacts are created and presented discursively. Sometimes these discourses are produced by habit, being repeated and imitated. Sometimes a new subjective force makes itself visible in the discourses.

The discursive dimension throws light on market expectations, the perceptions of industry insiders, the small-talk at business conferences; all of these have real life business implications. Therefore, when we study the reefer companies from a discursive dimension, we focus on how the persons involved describe their companies, how the company is represented in archival material of various kinds. We also study how the companies make sense of their cargoes, ships, and also other actors, such as competitors. For example, we have already argued that the way we understand the word "reefer" has been an important factor in shaping actions of reefer companies. The same goes with the word "container" as we will show.

\subsection{The Subjective}

The third dimension is the subjective. In general, this zooms in on the human actors that are part of the industry, understanding their perceptions, their views, and their psychological relation to the material and discursive dimensions of the industry. Here, we locate the human actors' agency to initiate material and discursive action. This is the dimension which captures the intentional strategies of actors. We have mentioned above that actions are influenced by discursive and material realities. In a sense, the subjective dimension points to the residual - to the share of human action that is not determined.

19 Boje, D. 1991. The storytelling organization: A study of story performance in an officesupply firm, Administrative science quarterly, 3: 106-126. Czarniawska, B. 1998. A Narrative Approach to Organization Studies, London: Sage. Kristensson Uggla, B. 2002. Slaget om verkligheten. Filosofi, Omvärldsanalys, Tolkning, Stockholm: Symposion. 
Also, it points to the desires and drives, fantasies and imaginations, of the involved actors.

This subjective dimension encompasses the lived experience of friendships, ethnic loyalties, patriotism, or for that matter, dislike which shape business decisions. There have been cases, for example, where ship-owners have firm opinions about who they will do business with. Rather than selling to the highest bidder, social considerations may outweigh rational, economic motivations. These considerations have been largely ignored by the business relationship literature ${ }^{20}$. The subjects' desire for prestige can result in the seeking of contracts with major fruit companies. The pursuit of prestige can lead to a desire to keep ships well-painted - aesthetic considerations.

Moroever, perceptions of reality are part of the subjective dimension. The later years of the reefer industry have been marked by a decline which is as much perceived as it is actual. Perceived decline influences which actions are seen as viable. Similarly, the perceived boom in earlier years led to an investment in reefer ships that flooded the market.

However, most of the strategic literature seems to assume that strategies are formulated rationally, as a means to reach a certain desired end - for example to earn money, to grow the business, or to expand market share. By highlighting the subjective dimension, which for us can consist of much more than a rational, instrumental means-end calculus, we open up for a more nuanced way of understanding the psychologies in the industry.

We further choose to divide this dimension further into three interrelated constituents: eros, thymos, and logos. Eros means a search for instantaneous gratification, the primordial drives, the urges. Thymos covers the posture of pride, desire for recognition. Logos means the rational and structured application of means to reach a certain end. Plato ${ }^{21}$, which has inspired the use of these three concepts, describes their interrelation as that between a charioteer and its two horses. One horse, eros, is constantly seeking to satisfy its desires and appetites, pulling in different directions and subjecting the chariot to uncontrolled, but forceful movements. The other horse, thymos, is stout-hearted, proud, and courageous. It holds its head high and has the confidence to go on. Logos is the charioteer who as far as possible tries to control the two horses. Logos thinks of itself as the locus of strategy, controlling the movement of the chariot, but much of the movement is decided by the interplay between eros and thymos. 
We hold that in order to understand an industry, it is important to also include this subjective dimension. When we describe the actors from a subjective dimension, we will try to get a glimpse of what really motivates them, going beyond the discursive and the material. For example, when it is obvious that an actor is rationally seeking to increase the company's wealth, this would correspond to the dimension of logos. When a company engages in business because of the status and pride it gives the actor, we might be dealing with thymos. And when a company is immersed in the market, making deals for the deals themselves, it might correspond to eros.

Our primary research question is thus developed as: How have the independent reefer operators, individually and collectively, developed in their material, discursive and subjective dimensions since their beginning until today?

\section{7 \\ The Structure of the Book}

In this introduction, we have already indicated several of the factors influencing strategies in the reefer industry, for example seasonality, containerization, and so on. In chapter 2 will set the stage for the corporate narratives that follow. A historical narrative of the macro level factors is presented, thereby describing the environment in which the reefer shipping companies operate. In part two, we will present a number of corporate narratives of the independent reefer operators, describing the history from the perspective of each company. In part three, we describe some important customers and competitors, in order to see the independent reefer operators from another perspective. In part four, we conclude the book by doing an analysis of the strategies of the independent reefer operators, based on our theoretical framework. 


\section{The Reefer Industry in a Historical Context}

This book follows the independent reefer operators from their birth until the present day. The following macro level description serves as a background and general context to the corporate narratives that we will present in the rest of the book. The independent reefer operators are part of the maritime link in the cold chain, which in turn is connected to the development of agriculture, international trade, technological and political developments. To fully describe this would be beyond the scope of this book. Instead, we sketch some basic contours which are relevant to the understanding of the development of the independent reefer operators.

Also, the discursive construction of the reefer, which we explained in the introduction, complicates the limited historical data that is available. For example, reefer tonnage is sometimes included with refrigerated liner capacity, and sometimes not. Smaller reefer vessels are frequently excluded from data sets and processes of inclusion and exclusion vary and are usually not explicit. Therefore, the description below is not aimed at giving a quantitative overview of the development of the industry, even though some data is used for illustrative purposes.

\section{The Beginnings: Meat, Bananas and Fish}

The refrigerated shipping market was born in the late nineteenth century, initially with the meat trade. This development, as well as the banana and fish trades that followed, will be descibed below. The timing of the birth of the refrigerated trades fits well into the development of the shipping industry and the emerging systems of international trade. From 1842 to 1887 , the sea trade of general cargo grew by $4.2 \%$ per year. The advent of steamships made long-haul trades viable for a greater range of cargo than before. Previous trades with luxuries like spices, silk and sugar could now be supplemented with less valuable cargoes. One outcome of this was that colonial possessions that didn't produce these luxuries could now generate more value since shipping costs were reduced and the cargo spent less time at sea. Without the transformation of the shipping industry from sail to steam, from wooden to iron hulls, using screw propellers, and a deep-sea communications network these international trades 
could not have emerged. At the same time, the prospects of international trade fuelled such shipping innovations.

Towards the late 1800 s there was a constant pressure to make the long-haul trade more effective with more efficient engines (reducing the fuel consumption by $75 \%$ per ton mile from 1855 to $1915^{1}$ ), and to increase the speed of shipments further. The passenger traffic and mail contributed to the commercial pressures to increase the speed of shipping ${ }^{2}$. This increased pressure for speed was also a prerequisite for carrying sensitive reefer cargoes.

The reefer trades are thus a natural part of the more general trends of industrialization, the development of long-haul international trade, and the largescale technological transformation of the shipping industry. Given the sensitive nature of the reefer cargo, the emergence of such international reefer trades was also dependent on the development of refrigeration technology, although early attempts involved the use of natural ice.

\subsection{Meat}

The early refrigerated shipping market was mainly concerned with transporting frozen meat to the growing and increasingly affluent British population. While local British supply was scarce, meat was abundant in the British Dominions of Australia and New Zealand, and also in Argentina and elsewhere in the Americas ${ }^{3}$. Early, canned meat was imported and also chilled meat from North America using natural ice ${ }^{4}$. But canned meat wasn't able to satisfy the market and the North American exports declined in the late 19th century. To be able to secure long-distance imports, there was a need for refrigerated vessels, or rather, freezers. Meat, compared to other refrigerated cargo that would appear later, was, in retrospect, a quite simple cargo to transport. It basically needed to be kept below freezing point.

Experiments with emerging refrigeration technologies were proceeding and the market opportunity prompted their refinement. The first freezing works were built in Sydney in $1861^{5}$ and soon the technology was applied to shipping. Initial Australian attempts to ship meat failed but were soon followed by

1 Stopford, M. 2009. Maritime Economics, New York: Routledge, p. 26.

2 Stopford 2009, p. 23.

3 The early history of British meat imports is described in Oddy, D.J. 2007. The Growth of Britain's Refrigerated Meat Trade 1880-1939, The Mariner's Mirror, 93: 269-280.

4 Perren, R. 2006. Taste, Trade and Technology: The Development of the International Meat Industry since 1840, Aldershot: Ashgate, p. 47-49.

5 The history of early Australian meat exports is based on Pearson, M. and Lennon, J. Pastoral Australia: Fortunes, Failures and Hard Yakka: a Historical Overview 1788-1967, Collingwood: CsIro Publishing, pp. 68-70. 


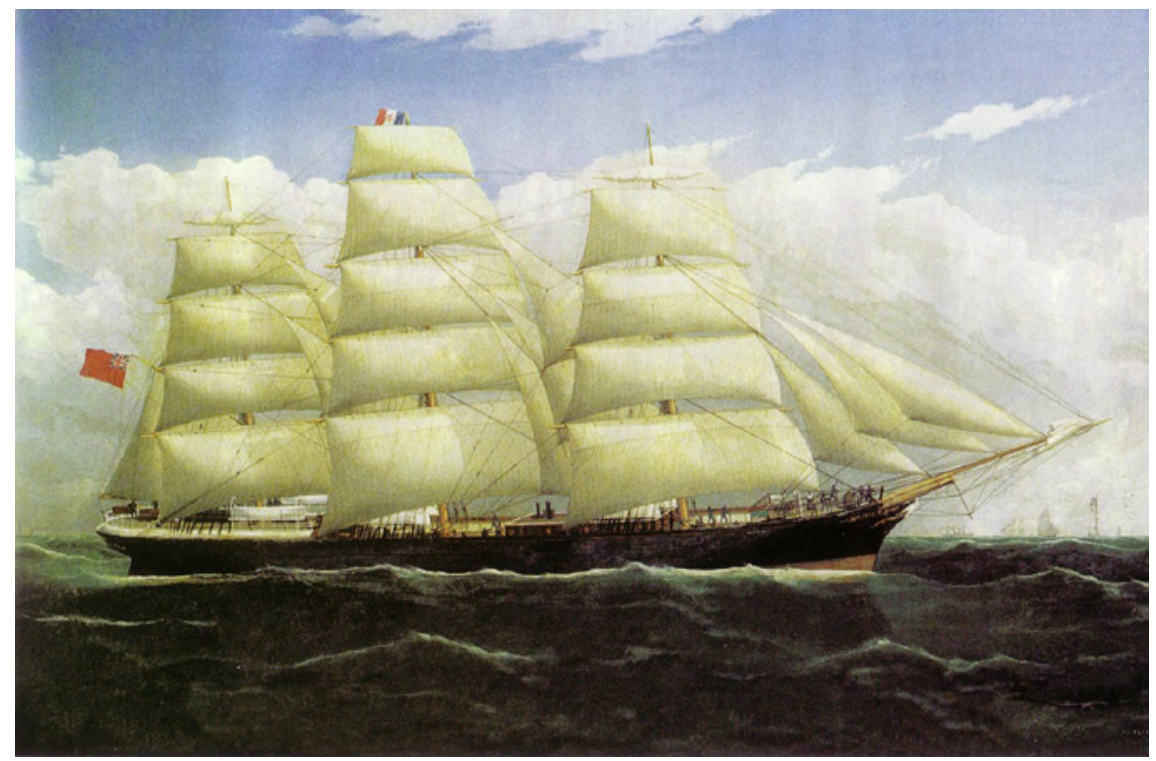

FIGURE 2 The Dunedin's successful voyage in 1882 established the viability of modern refrigerated shipping. Pictured in Shaw, Savill and Albion Line colours, and prior to the fitting of its refrigeration machinery. The ship was lost near Cape Horn in 1890. Painted by Frederick Tudgay in 1875 IMAGE SOURCE: HOCKEN LIBRARY

a limited French success with the Frigorifique in $1877^{6}$ and more so with the Paraguay in 1878. The voyage of the clipper sailing ship Dunedin, which was retrofitted with coal-powered compression refrigeration, from New Zealand to the UK in 1882 was a successful venture, inspiring others to equip vessels with refrigeration.

Thirty years later, in 1912, there were 251 vessels with a total of $44 \mathrm{~m}$ cbf of refrigerated cargo space employed in the meat trades 7 . A common size of a reefer hold was about 180 ooo cbf, although some vessels had about $530000 \mathrm{cbf}$ of refrigerated capacity ${ }^{8}$. Many of the vessels were not specialized reefer ships, but cargo liners with a "half and half" configuration, half frozen and half general cargo, and others merely had some minimal refrigerated locker space. The

6 The cargo was chilled to o degrees and a significant part of the cargo was spoiled. Wijnolst and Wergeland 2009, p. 287.

7 Critchell, J. \& Raymond, J. 1912. A history of the frozen meat trade, an account of the development and present day methods of preparation, transportation, and marketing of frozen and chilled meats, $2^{\text {nd }}$ ed London: Constable \& Company.

8 Dellacasa, A. 1987. Refrigerated transport by sea, Rev. Int. Froid, 10: 349-352. The early period is described on pages $349-35^{\circ}$. 
infrastructure of modern cold storage plants on land was also expanding. A company that eventually managed to make the most of this early refrigerated market is the meat and shipping empire built by the Vesteys, including Blue Star Line (see chapter 8).

\subsection{Bananas}

Long before reefers came into the picture, large volumes of bananas were shipped to the United States. The first recorded banana shipment to New York was by schooner from Cuba in 1804. Irregular, small-scale shipments commenced $^{9}$. They were constantly at the mercy of favourable winds, and spoilage was a major problem. On the other side of the Atlantic, some regular cargo vessels had sporadically carried bananas from the Canary Islands to Europe.

It was the establishment of large-scale plantations in Central America, producing enormous volumes at low economic (albeit not social and environmental) cost, in conjunction with railroads, that created a major market for bananas in the United States in the late 180os. More than 12 million bunches of bananas passed through U.S. ports in 1892 and bananas were considered a "staple article" and they featured in recipe books ${ }^{10}$.

These large-scale plantations were developed by the forerunners of the companies that became United Fruit (now Chiquita) and Standard Fruit (Dole). Close relationships were built up between the companies and political interests in these countries that resulted in major land concessions to the fruit companies. This was a capital-intensive business which resulted in just a few vertically-integrated companies dominating the market. Capital and power in the banana industry tend to concentrate, as Soluri puts it, "in between farms and kitchens". Indeed, legendary "banana men" like Lorenzo Dow Baker, Minor Keith, the Vaccaro brothers, and Samuel Zemurray, all began their carreers as shippers, railroad builders, and wholesalers, not planters ${ }^{11}$.

By the late nineteenth century there was a well-developed infrastructure supplying the United States with bananas. The bananas were brought to market by rail, then steamboat, and then rail again in the United States. The transformation from sail to steam in the shipping industry increased the speed and reliability of the shipments. Spoilage was reduced by improving the cargo's ventilation, vents were added and fans to remove the ethylene gas that bananas produce, expediting the ripening process. These ventilated fruit carriers were a modest improvement over the ordinary cargo vessel. Using the reefer

\footnotetext{
9 Soluri, J. 2005. Banana Cultures, Austin: University of Texas Press, p. 36.

$10 \quad$ Soluri 2005, p. 36-37.

$11 \quad$ Soluri 2005, p. 226.
} 
vessels developed for the meat trade were not an option since bananas are subject to chilling damage and the first reefers could not manage the optimal 12-13 degrees ${ }^{12}$.

The competition between the banana companies was intense and one area of competition was the market's perception of whose bananas were the best. Fruit buyers preferred blemish-free fruit and bunches with as many bananas as possible. To achieve this quality fruit required a high amount of investment in the most uptodate logistics (and later also chemical treatments). For the major banana companies, it was a strategic advantage to develop and invest in refrigerated banana transport.

While the banana majors focused on satisfying the demands of the us market, they also realized that if the quality of maritime transport would improve, the lucrative potential of the overseas, European, market was within reach. British companies were already showing an interest in the transatlantic banana trade and this threatened the existing set-up with United Fruit being dominant and with Standard and Cuyamel as the secondary players.

In the race with bananas across the Atlantic, a British company emerged as the first-mover. The first ship to carry bananas in a reefer hold was the Imperial Direct West India Line's passenger liner Port Morant that shipped bananas along with mail and passengers from Jamaica to Bristol in 1901, about twenty years after the arrival of the frozen meat cargo in London. The cargo arrived in good condition and a regular banana trade with bananas to Europe was inaugurated. To compete with the European shipping lines, in 1903, United Fruit shipped bananas across the Atlantic with the 25 -year old Venus, a river freighter that was retrofitted with primitive refrigeration equipment consisting of ice blocks, animal hair, air ducts and fans ${ }^{13}$. A relationship with Elders \& Fyffes was formed to develop the transatlantic banana trades. Cuyamel (later joining with United Fruit), Standard Fruit (later Dole) and French fruit interests also acquired reefers for long-distance trades. It is estimated that United Fruit controlled as much as $77 \%$ of the world trade in bananas at this time ${ }^{14}$.

The development of suitable reefer transportation in the early 19oos enabled large-scale exports to Europe and the gradual emergence of a global banana market. Public awareness of the health benefits of eating fruit were a

12 Tolerton, N. 2008. Reefer Ships: The Ocean Princesses, Christchurch, NZ: Willsonscott Publishing.

13 Cohen, R. 2012. The Fish that Ate the Whale: The Life and Times of America's Banana King, New York: Random House.

14 Taylor, T. 2003. Evolution of the banana multinationals, in Josling, T.E. and Taylor, T.G. Banana Wars: The Anatomy of a Trade Dispute, California: Institute for International Studies Stanford University, pp. 67-96. 
factor that stimulated demand. The banana also benefited from widespread concerns about germs; the banana, with its peel, was considered a hygienic choice. In time, they became the most important commodity carried by reefers but it remained a luxury commodity in many parts of the world until after the Second World War and in other places not until much later.

\subsection{Fish}

While fishing vessels often return from fishing grounds when the cargo holds are full, another common practice is to offload the cargo to transport vessels that carry the fish to shore. Traders have often sought out fishermen offshore to buy their cargo at a price beneficial to both parties and quickly get it to the markets. With growing populations and more effective means of fishing, particularly the advent of efficient trawling in the beginning of the 190os, fish stocks in rivers and near the coast have gradually been reduced, and fishing has moved farther offshore. Refrigeration technologies are a prerequisite for these long-distance fish trades in the same way as they are to the banana and meat trades described above ${ }^{15}$.

Mechanical freezing of fish kicked off in the late 1800 s at onshore refrigeration sites. The fish was placed on metal plates in contact with a pipe grid where a refrigerant was circulated. Before that, fish was kept cold using natural ice. An early record suggests that in 1797, natural ice was used to preserve fish on imports to the UK. In 1911, the Danish Ottesen patented the process of freezing fish in brine, and gradually ships were equipped with the Ottesen installation and other freezing equipment. The Japanese government subsidized the introduction of these refrigeration technologies at the beginning of the 2oth century ${ }^{16}$.

The experimentation with banana shipments across the Atlantic was interrupted by the First World War. Most of the commercial fleets were tied up in war activities, and during the War, navies as well as merchant fleets were decimated. After the War, trade caught up which caused a demand for shipping. Frozen meat, and rapidly increasing quantities of chilled meat, was transported from

\footnotetext{
15 Dellacasa 1987. Some notes about fish transports are found on pp. 349-350.

16 Nissui. 2012. A History of Hundred Years of Nippon Suisan Kaisha, Ltd., p. 26. Available at: $<$ http://www.nissui.co.jp/english/corporate/10oyearsbook/pdf/10oyearsbook.pdf>.
} 


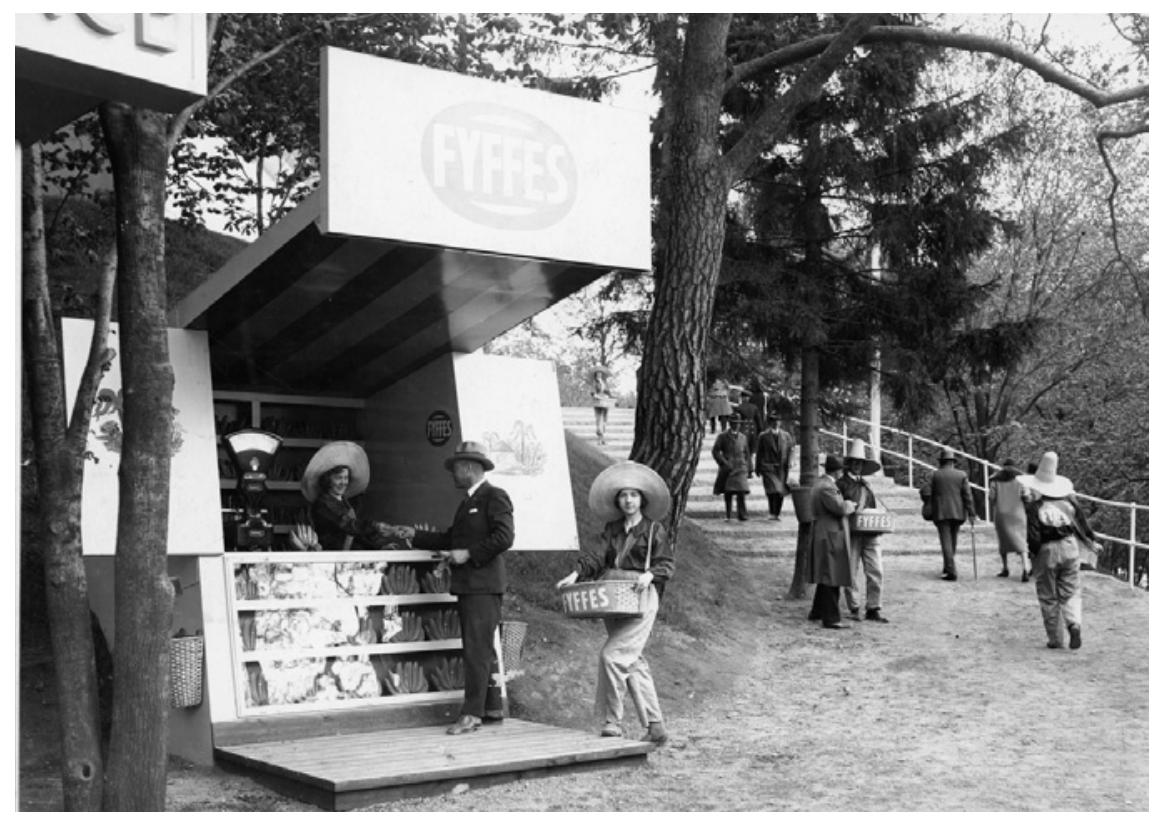

FIGURE 3 Reefer shipping opened up new markets for tropical fruit. Banana marketing by Fyffes at the Stockholm Exhibition in 1930 PHOTO: ARKITEKTUR- OCH DESIGNCENTRUM

the Southern Hemisphere, complemented with dairy products ${ }^{17}$. Moreover, apples and pears, particularly from New Zealand, were carried ${ }^{18}$.

The transatlantic banana trade also grew. New fruit and banana trades were initiated by colonial powers, for example bananas from Italian Somaliland to Italy. The song "Yes! We Have No Bananas" released in 1922 was a major hit. Banana marketing efforts were initiated by the fruit companies in order to teach Europeans to eat bananas and to penetrate the us market even further. By 1929, exports from the banana producing areas of tropical America reached a world-record of 29 million bunches, up dramatically from the 8.4 million of $1912^{19}$.

The banana business became more capital intensive due to the cost of managing the problems caused by two diseases. One of them, Panama Disease, was managed by flooding land areas that were affected while the other, Sigatoka,

17 For a view of Australian exports of meat and dairy products to Britain, see Burley, K. British Shipping and Australia 1920-1939, Massachusetts: Cambridge University Press.

18 Wijnholst \& Wergeland 2009, p. 288.

19 History of the Banana: 1800 to present, Available at: <http://cwh.ucsc.edu/bananas/Site/ Modern\%2oHistory\%2oof\%2othe\%2oBanana.html>. 
was managed by chemical treatment. The increased capitalization created barriers to new entrants in the banana market and favoured the development of the banana majors.

In the 1920s Japanese fishing companies introduced refrigeration onboard vessels and they also built cold stores on shore. The greatest cost for fish was the transport cost and the cost of crushed ice for refrigeration and innovation could be the way out of this situation ${ }^{20}$. In-house on shore ice making facilities were a way for Nissui to lower their costs, rather than relying on a third-party provider. Some fishing companies thus were quite vertically integrated. However, on shore refrigeration equipment helped little when it came to distant water fishing. On-board freezing equipment was necessary. In 1930, new rapid freezing equipment was installed on a handful of Japanese trawlers ${ }^{21}$. As before, the trawlers sometimes went back ashore after filling their cargo holds, but sometimes they transshipped the cargo to a transport vessel, a reefer, which took the fish ashore.

The British refrigerated fleet was the largest in the interwar years, estimated three-quarters of the world fleet in terms of cargo volume in 1923 and twothirds in $1939^{22}$. Reefer tonnage, as with all shipping, was catastrophically affected by the Second World War. The merchant fleet was therefore supplemented by the construction of swiftly constructed "Empire" vessels. These vessels were of many types and included refrigerated cargo liners. The Empire Clarendon and the Empire Abercorn, for example, had refrigerated capacities of over 360 ooo cbf and a service speed of 14.5 knots. They later sailed for Blue Star Line and the New Zealand Shipping Company, which also constructed the important Haparangi class in the late 1940s, consisting of eight large cargo ships with a high capacity for refrigerated and frozen goods.

Refrigerated and frozen cargo during these years continued to be carried in various types of ships. Many were general cargo vessels with a refrigerated capacity that could be as little as refrigerated lockers. These were liner trades and were usually regulated by the shipping conferences. There were also dedicated reefers, particularly for the banana trade, but even these frequently carried passengers. Ventilated fruit carriers and general cargo vessels continued to carry fruit, particularly for shorter distances, for example from the Caribbean to USA and in the Mediterranean and Baltic Seas. Lauritzen and Saléns started to operate in these regional trades but had the ambition to service the transatlantic reefer trades.

\footnotetext{
$20 \quad$ Nissui 2012, p. 63.

21 Nissui 2012, p. 77.

22 Wijnolst and Wergeland 2009, p. 288.
} 
The post-war refrigerated shipping market was constrained in a number of ways and its growth was initially modest. Many important markets for perishables were in ruins, particularly in Europe and East Asia. Following the General Agreement on Tariffs and Trades, the signatory countries lowered tariffs which contributed to the growth of world trade. This combined with postwar reconstruction contributed to the start of a period of economic prosperity in the 195 os for most industrial countries, which increased the trade of various goods (oil, ore, grain, etc). This affected the shipping industry positively, also increasing the demand for refrigerated tonnage. It wasn't long before bananas and other imported fruit were a part ordinary people's lives in prosperous regions. The demand side was slowly recovering. In 1961, the world reefer trade was about 18 million tons, while at the end of the same decade it had increased to around 25 million (see Graph 5).

But during the 1950s and 196os, the shipping industry also underwent a transformation from the structure of cargo liners, passenger liners and tramp ships that had existed since the early 19oos. In this period, the cargo liner companies were undergoing a revolution as the modern intermodal container began to make serious headway ${ }^{23}$. In 1969, the first purposebuilt reefer container ships were introduced by OCL and $\mathrm{ACT}^{24}$. This posed significant demands on new terminals and new cargo handling equipment and skills related to general cargo. For the reefer cargoes, the challenges were even bigger. Early refrigerated containerization was based upon the idea that the ship had central refrigerated units and the cold air was ducted to what are usually referred to as porthole containers. However, early refrigerated containerization was not a success and this created great opportunities for independent reefer operators. This coincided with increased consumer expectations for off-season produce, for example, apples in the supermarket year-round. Also, the partly refrigerated passenger liners were a dying breed and the passenger traffic they had carried had dwindled as the jet-era of mass tourism had begun.

The general trend was that the general cargo was containerized, the passenger traffic and mail gradually shifted to airlines, and that a number of specialized shipping segments were emerging ${ }^{25}$. Specialized bulk shipping vessels

23 For more background on containers see Levinson, M. 2006. The Box: How the shipping container made the world smaller and the world economy bigger, Princeton: Princeton University Press, and, Donovan, A. and Bonney, J. 2006. The box that changed the world, Ubm Global trade. See also Klose, A. 2015. The Container Principle, Massachussetts: MIT Press.

24 Wijnolst and Wergeland 2009, p. 288.

25 Stopford 2009, p. 36. 
such as oil tankers had existed but developed significantly during this period - their size grew exponentially, given that the transport cost per unit decreases with increasing ship size. A similar but not as pronounced tendency can, as we will see, be witnessed in the case of reefers.

Perhaps the timing of this transformation of the shipping industry was not unexpected. Tonnage losses, as previously mentioned, had been enormous during the Second World War, and the fleet that survived was soon obsolete. This presented opportunities, however, to renew the transport system within all shipping segments. Technological advances had been strong within fields such as refrigeration and automation, and such advances trickled down into the maritime reefer industry. The 1950s and 196os therefore turned out to be a period of innovation and it enabled the subsequent boom in perishables transport in the decades that followed. Improved refrigeration reduced spoilage. Automation and more reliable machinery reduced maintenance and crewing requirements. Some vessels had unmanned engine rooms. The refrigeration systems were also improved and the development of electronics made systems of automatic temperature control possible. Modern vessels could manage a wide range of temperatures, handling many types of cargo with different atmospheres in its separate gas-tight compartments. Improved cargo handling and faster vessels reduced turnaround times drastically. Speed was a major factor due to the precarious nature of the cargo. While the speed of reefer vessels before the Second World War were often around 15-16 knots, this increased and for example Lauritzen's Italian Reefer class boasted a speed of 22 knots in 1968 (see Graph 4).

Apart from the general developments in world trade and the shipping industries, the reefer industry was impacted by developments in their respective cargo categories. Regarding bananas, the Panama Disease all but wiped out the Gros Michel banana in the 1950s, and this led producers to develop a diseaseresistant variety, the Cavendish ${ }^{26}$. However, the Cavendish was more fragile and easily bruised during handling. To solve this problem, the banana companies started to pack them in boxes prior to shipment. The increased operating cost associated with boxing and disease control contributed to economic problems for both United Fruit and Dole. Both companies subsequently reduced their own fleets in order to free up capital. Their shipping needs were increasingly supplied by independent reefer operators like Saléns and Lauritzen.

26 The Cavendish is the main variety internationally traded today. Plantains used as food in India and many parts of Africa actually constitute the largest volume of bananas that are grown. The Cavendish banana is presently being ravaged by a different strain of Panama disease in many parts of the world. A replacement is being sought and efforts are also being made to genetically engineer a resistant variety. 


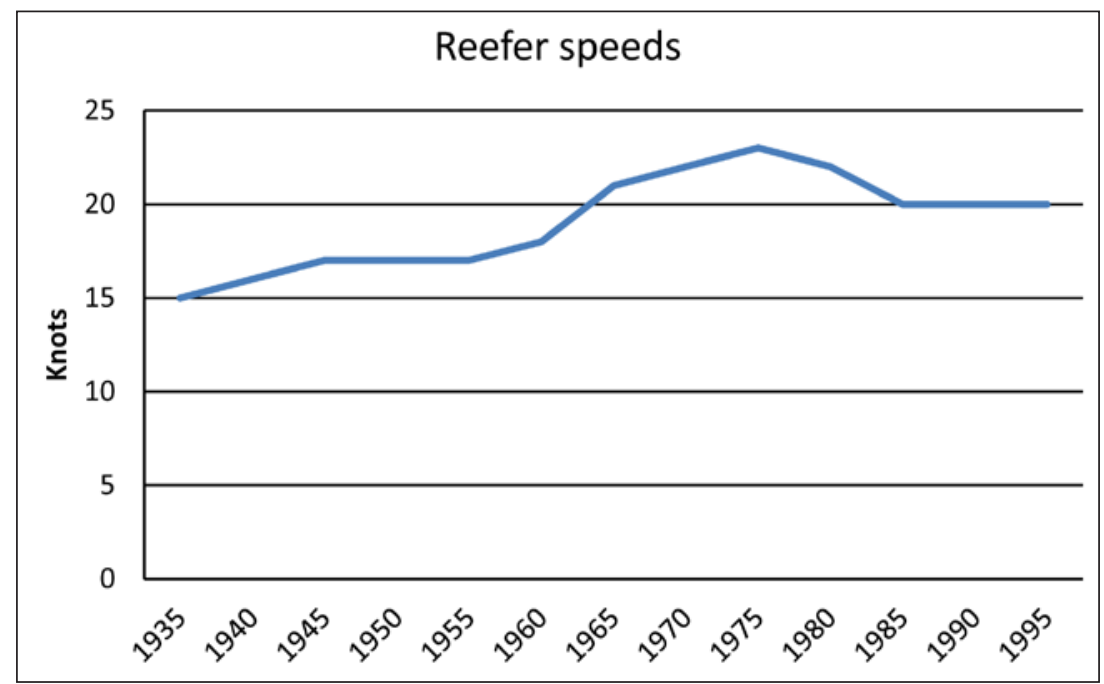

GRAPH 4 Reefer speeds. The graph gives the typical rated speed for newly constructed large reefers. The lower speeds after the late 1970 s is due to the prioritisation of fuel efficiency following the oil crises.

Note: Created on the base of indicative speeds of large reefer newbuildings from 1935 to 1995 from Tolerton 2008.

Regarding fish, fishing fleets continued to search further afield and increased the necessity of transshipment. A new development within the fishing industry was the growth of the international fish trade and this provided a new business where fish was transported from port to port. For example, Gustaf Erikson's 1957 newbuilding Fiskö went directly from the shipyard to load fish in Reykjavik, Iceland ${ }^{27}$.

Similar to the unitization of the liner companies, unitization was also discussed within the reefer trades. The cargo on reefer vessels were of varying kinds, sizes and shapes, and given the inefficiency of handling such cargo, the reefer industry started to consider the unitization of cargo. Although some experiments had been made with container technology, the major breakthrough was palletisation. Palletisation began in earnest and Saléns started an integrated pallet service for Sunkist in 1969 .

27 Malmberg, T. and Hag, E. 2013. Kalla Systrar från Åland på världens alla hav, Mariehamn: Stiftelsen Hilda och Gustaf Eriksons samt Gustaf Adolf Eriksons Understödsfond, p. 9091. 
The 1970s promised to be a golden era for the independent reefer operators. The liner industry was struggling with refrigeration, while the demand for perishables was increasing year by year. New, modern ships, like Salén's Snow class and Blue Star Line's A-class, were ordered, and new entrants were eyeing the reefer segment. The liner conferences' importance diminished during these decades $^{28}$. This presented more cargo opportunities for the independent reefer operators.

However, the oil crises of the 1970s drastically raised operating costs, and combined with oversupply of tonnage, translated into weak profitability. Given the increased cost of bunker fuel the operational speed of newbuilt reefers stagnated. While the focus had been on pushing up the speed for each successive generation of reefer vessels in the 1950s and 196os, the oil crises of the 1970 stopped this development. This is not to say that reefers were slow ships - a typical reefer speed stabilized at 20 knots. However, the rise of oil prices led to more concern with bunker consumption than in previous periods (see Graph 4).

Due to the oil crises, there was an abrupt end of the boom in the shipping market that had been ongoing since the 1950s. This cascaded into the shipbuilding market which was of central concern to the governments of shipbuilding nations ${ }^{29}$. European governments subsidised national shipbuilding in the 1970 s and 1980s to remain competitive and avoid the unemployment that would result if the shipyards were closed. Many shipping companies, including the reefer segment, seized the opportunity to build vessels, but in general the verdict is that this resulted in an oversupply of tonnage in all ship categories. State subsidised shipbuilding was threatened by the Gibbons Bill in the Us, which would have prohibited subsidized vessels from entering ports in the Us $^{30}$. Subsequently, shipbuilding became more competitive and most reefers in later decades were built in East Asia.

Still, the demand for transport of refrigerated products grew. Graph 5 shows the development of the international trade in refrigerated products. In the 1970 s and 1980s, the trade of refrigerated products increased. In 1970 it was around 25 million tonnes while in 1990 it had risen to almost 50 million tonnes.

\footnotetext{
28 Stopford 2009, Chapter 13.

29 Todd, D. 1991. Industrial Dislocation: The Case of Global Shipbuilding, London and New York: Routledge.

30 Waters, R.C. 1993. Federal Regulations and the Competitiveness of U.S. Liner Ship Operators, Transportation Journal, 33: 53-58.
} 


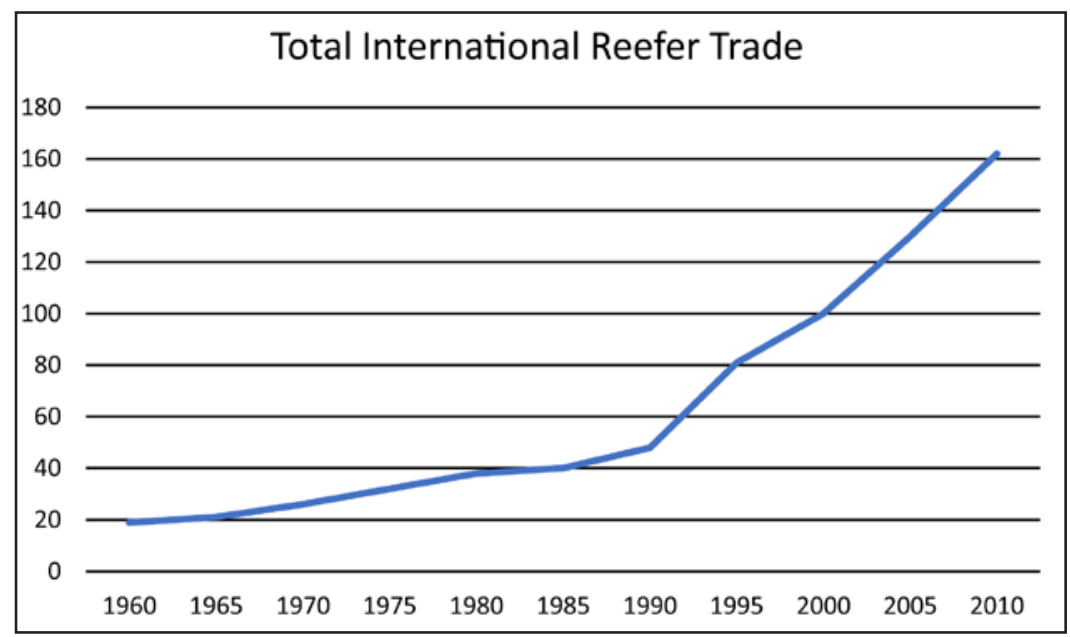

GRAPH 5 Total international reefer trade (not just seaborne)

Note: Modified from: Arduino, G. and Parola, F. 2010. Cold Chain in the Shipping Industry: Bulk versus Container in the Banana Trade, 12th World Conference on Transport Research, July 11-15, 2010 - Lisbon, Portugal. Figures are in turn drawn from Nomadic ASA and Drewry with authors' elaboration.

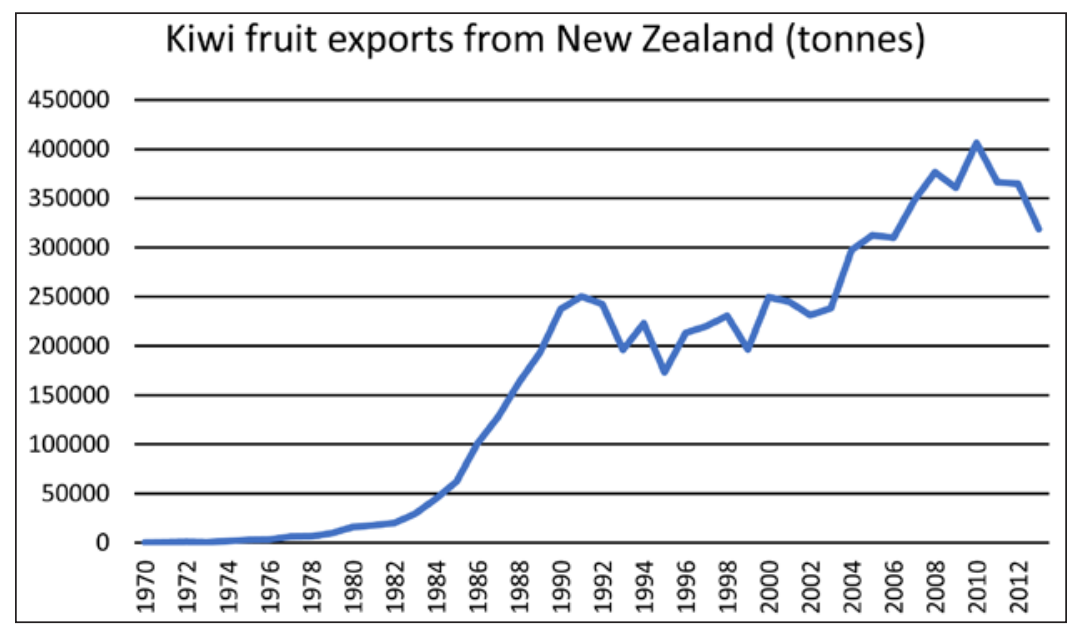

GRAPH 6 Kiwi fruit exports from New Zealand (tonnes)

Note: (c) FAO, Food and Agriculture Organization of the United Nations, <http://www.fao.org/faostat/en/\#data/TP>. 


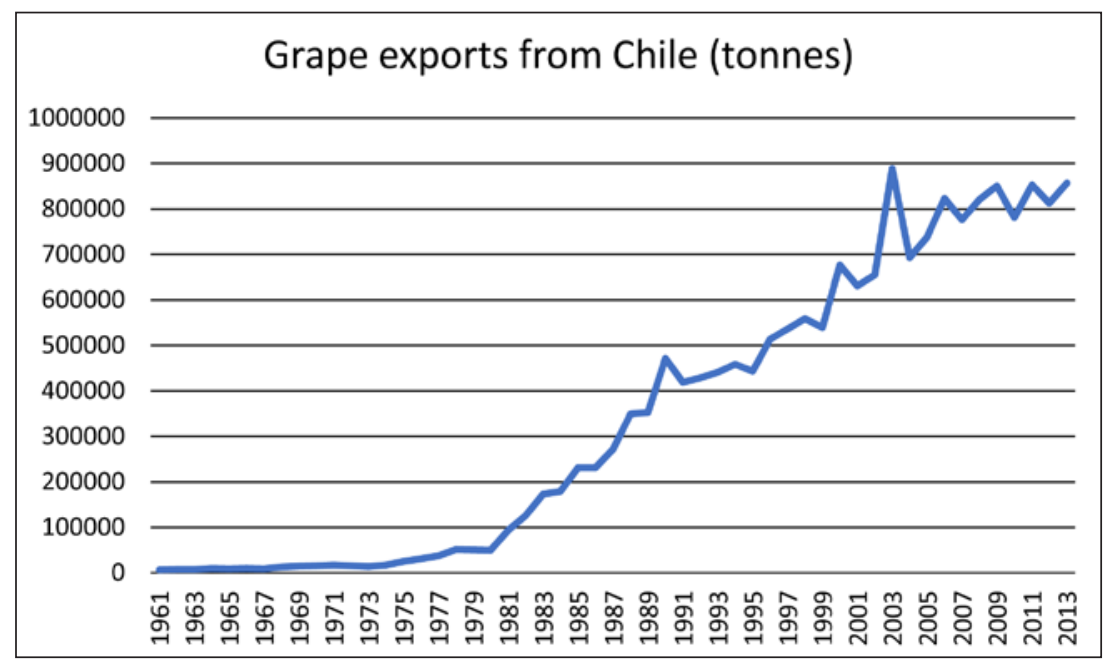

GRAPH 7 Grape exports from Chile (tonnes)

Note: (c) FAO, Food and Agriculture Organization of the United Nations, <http://www.fao.org/faostat/en/\#data/TP>.

Exported volumes of grapes from Chile and kiwifruit from New Zealand grew rapidly during the 1980 os (see Graphs $6-7$ ). The ship supply increased accordingly. From a capacity of $250 \mathrm{~m} \mathrm{cbf}$ in 1980 it increased to about $325 \mathrm{~m}$ in 1990 (see Graph 8).

The palletisation process which gained traction in the 196os, continued into the 1970 s and 1980s. As a result, new pallet-friendly reefers were built with optimised deck configurations. The idea was to maximise the number of pallets that a ship could carry. The height of each deck was designed to cater for fully stacked pallets and the ships were also built "squarer" to avoid unutilized cargo space in the holds. This was also done in order to increase speedy deliveries even though the ships were not sailing faster. The old breakbulk reefers continued to see service for many years as backup tonnage and for service in the fish trades. Palletisation also brought with it a change in cargo handling equipment. From derricks having been the major cargo handling equipment on reefer vessels, newer vessels increasingly came with cranes which could load multi-pallet cargo holders. 


\section{Palletisation and Pallet Heights}

The first reefers built for palletised goods were designed for pallets loaded to a height of approximately 1.9 metres, for example Salén's Snow vessels. This equated to the height of seven boxes of fruit and also allowed for a small amount of airspace above the boxes, for the proper circulation of cold air. During the 1970s, however, the Confederation of Importers and Marketing Organisations in Europe of Fresh Fruits and Vegetables (сімо) lobbied for this height to be increased. More goods per pallet would equate to reduced transportation and handling costs. The major fruit companies resisted this initially. On the one hand, the cartons that contained the fruit needed to be robust enough to handle the additional weight but, more significantly, the higher pallets wouldn't fit into the existing cargo holds. However, the oil crises made the existing fleets expensive to sail and thus there was an interest in obtaining new bunker-efficient vessels that could then also meet the new agreed up standard pallet height of approximately $2.1 \mathrm{~m}$ ( 8 boxes high). The new vessels were therefore built with a deck height of $2.2 \mathrm{~m}$, once again allowing sufficient airspace above the cargo to allow the cold air to circulate. Older vessels were usually sold and considered obsolete by the major operators, at least for some of the fruit trades that attracted better freight rates. In some cases, for example the Snow vessels, they were converted by lowering the gratings on which the pallets rested and installing thinner insulation in the ceiling. While palletisation was ongoing, less modern vessels were still used by operators as a reserve fleet, which was laid up except for in high markets, or as ships that could serve fishing fleets.

During the 1990s and 2000s, the world underwent a process of privatization and liberalization of markets. Many fruit exporting countries had national export boards which acquired transport capacity. Often the exported quantities were high because of the association of many independent growers, leading to the potential to fill up an entire specialized reefer. However, many of these export boards have been dissolved, leading to more fragmented quantities which could be carried by liner vessels. On the demand side, there has been a growing number of large players, such as supermarket chains. Walmart is a good example. With considerable market control, major supermarket chains have a complex supply chain and meticulously control the supply of goods. It has 
been argued that such players prefer the continuous delivery of fruit, meat and fish rather than large but less-frequent bulk-deliveries supplied by specialized reefers.

The collapse of the Soviet Union and related political change opened up new markets for reefer operators. There was a demand for imported fruit in the post-Soviet and Eastern European countries, a demand that was previously inadequately supplied. The opening up of these markets also led to the entry of new players and ships on the market. Eastern Europe has grown in importance while Western Europe has declined in the first decade of the $200 \mathrm{~s}^{31}$.

On the demand side, the period after 1990 witnessed a veritable boom in the trade of refrigerated products. From the traded volume of $50 \mathrm{~m}$ tonnes in 1990, in 2010 the traded volume amounted to almost 170m tonnes (see Graph 8). Interestingly, this market boom coincided with a decline of specialized reefer tonnage. From the peak of about $380 \mathrm{~m}$ cbf of specialized reefer tonnage in 1994, the capacity has declined to about $230 \mathrm{~m}$ cbf in 2013, a bit lower than it was in 1980 (see Graph 8). The number of newbuildings since the 199os has decreased to the point that at the end of 2016 there were about 16 newbuildings in the orderbooks ranging between 120000 and $650000 \mathrm{cbf}^{32}$. Scrapping on the other hand has been on the increase, particularly since 2008 resulting in a dwindling world reefer fleet (see Graph 8).

At the high point for the independent reefer operators, in 1993, about $35 \mathrm{~m}$ tonnes of cargo was transported by ship ${ }^{33}$. Graph 9 shows the relative importance of the commodities carried by reefers. Bananas have occupied an exceptional position in the transport of refrigerated cargo.

A third of the maritime reefer cargo was carried in containers ${ }^{34}$, where the dominant cargo was meat ( $40 \%)$ followed by bananas $(20 \%)$, dairy $(13 \%)$ and other goods ${ }^{35}$. In 1998, $45 \mathrm{~m}$ tonnes was transported by ship ${ }^{36} .40 \%$ of this was bananas, something which has varied little since the 1980s. In 1997, when the capacity of the container lines overtook that of specialized reefers, the container lines still only conveyed $42 \%$ of the cargo. ${ }^{37}$ In 1980 , full reefers of more than 100 ooo cbf provided $65 \%$ of global capacity, but in 1997 this had fallen to

$31 \quad$ Damas, P. Reefer Market Overview, Drewry, Conference presentation, Long Beach 5 March 2013. "Healthy Orderbook for Reefers". The Maritime Executive 29 January 2017. <http://maritime-executive.com/editorials/healthy-orderbook-for-reefers>. "Kylsjöfart", Svensk Sjöfarts Tidning 1993/50, p. 72. "Kylsjöfart", Svensk Sjöfarts Tidning 1993/50, p. 72. "Kylsjöfart”, Svensk Sjöfarts Tidning 1993/50, p. 72. "Kylsjöfart", Svensk Sjöfarts Tidning 2000/50, p. 55 . Branch, A. 1998. Maritime Economics: Management and Marketing, New York: Routledge, p. 101. 


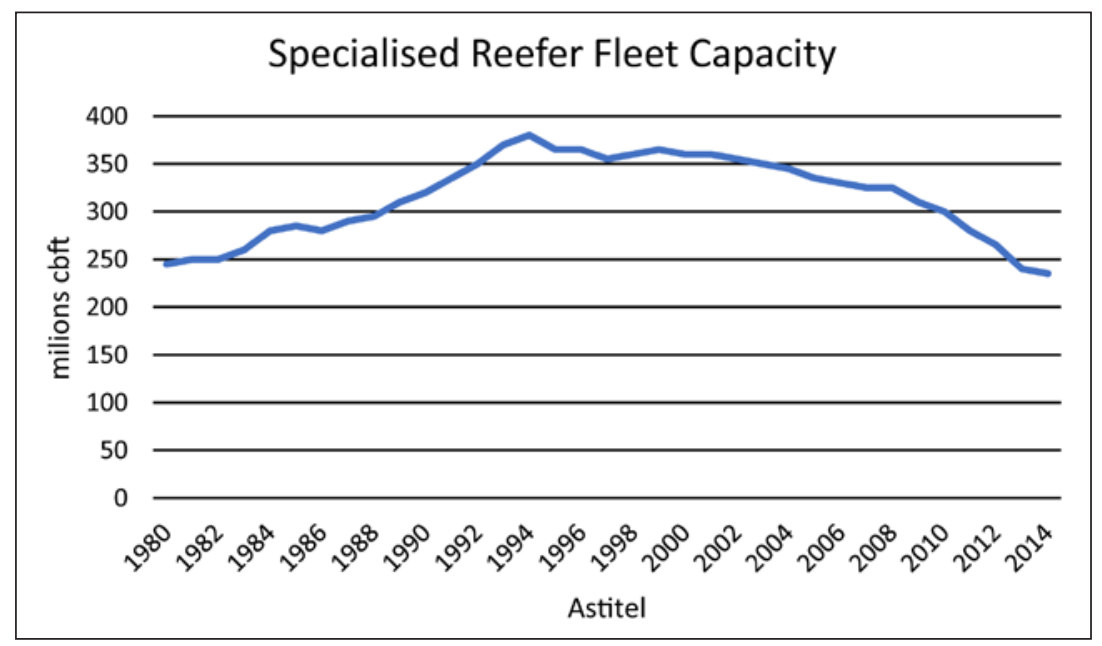

GRAPH 8 Specialised reefer fleet capacity

Note: Data supplied by Seatrade.

$47.2 \%$ under deck and 2.8 over deck. ${ }^{38}$ In 2019 , the share of the container lines is expected to reach $83 \%{ }^{39}$

Refrigerated containers began to make serious inroads into the refrigerated shipping market in the 199os. Integrated containers became the preferred technological choice because of their flexibility; they only required a suitable power source ${ }^{40}$. The growth of the refrigerated container business from the South to the North is also partly a result of the container lines desire to find backhaul cargo for their business. In other words, what was the main business for reefers, was interesting backhaul cargo for the container lines. The container lines were therefore willing to accept fruit in refrigerated containers at low rates in the same way that reefer operators were willing to frequently transport cargo at low rates on their backhaul routes.

As can be seen from Graph 10, from the early 1990s, reefer container capacity on ships has increased rapidly. It is now worth remembering that we are essentially dealing with a re-entry of liner operators into the reefer cargo, which was enabled by the technological development of the reefer container. Reefer containers gradually became more reliable, could control the temperature more accurately, and also developed systems for controlled atmosphere

\footnotetext{
$38 \quad$ Branch 1998, chapter 4.

39 "A Perspective on Refrigerated Container Trade Growth". GEP Mind. <https://www.gep. $\mathrm{com} / \mathrm{mind} / \mathrm{blog} /$ perspective-refrigerated-container-trade-growth>.

40 See also Wijnolst and Wergeland 2009, pp. 287-290.
} 


\section{Reefer Cargo by volume 1993}

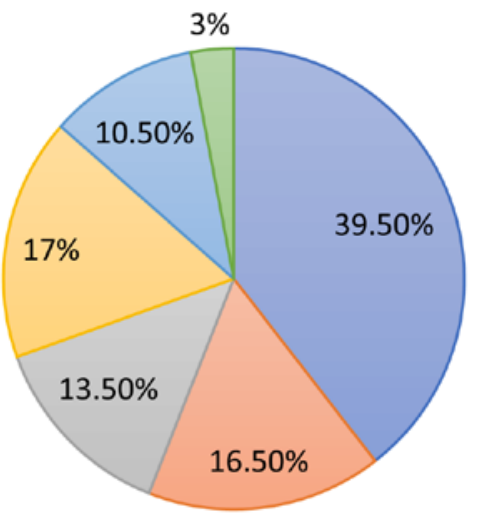

Bananas $\square$ Citrus $\square$ Other fruit $\square$ Meat $\square$ Fish $\square$ Other

GRAPH 9 Reefer cargo by volume (1993)

Note: "Kylsjöfart", Svensk Sjöfarts Tidning 1993/50, p. 72.

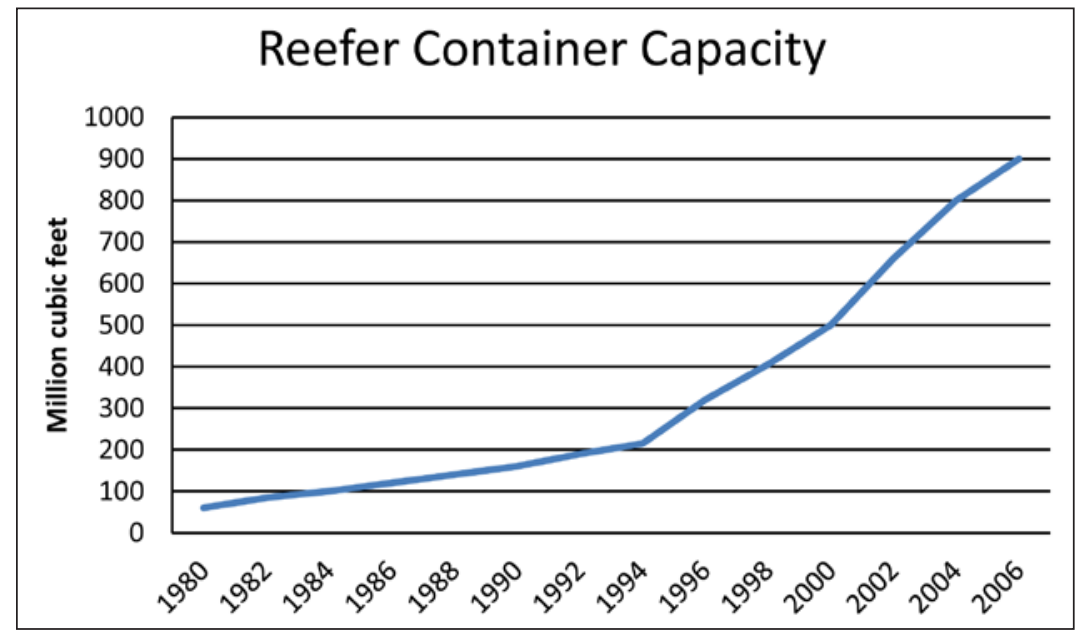

GRAPH 10 Reefer container capacity

Note: Note that this graph shows capacity, not what was actually used. Arduino and Parola 2010. Figures are in turn drawn from Drewry and Containerisation International. 
necessary to transport fruit. Due to the increased containerization, cranes on specialized reefer vessels are designed to carry heavier loads. A recent paper by Thanapolou ${ }^{41}$ discusses the specialized reefer market and shows that the bulk reefer market has reached the declining end of the product life cycle. Another recent paper by Arduino concurs with Thanapoulou's analysis and explains that the costs of transporting a pallet in a reefer container, vs. a pallet in a specialized reefer vessel is a major reason for this shift ${ }^{42}$.

This re-entry of container lines into the reefer segment led to increased competitiveness and also a need for specialized reefer operators to take strategic action. While the strategies of the various operators will be covered in the main bulk of the text, we can here say that regarding ships, more ships moved into the hybrid type, where the under-deck palletised cargo was complemented with reefer containers on the weather deck. Some operators have built reefer container vessels, which are small container vessels where the entire cargo can be refrigerated. There has also been development towards side-loading vessels, which are palletised reefers without hatches, making them insensitive to the weather. Furthermore, in the 2010s, the development of a reefer ro-ro ship was discussed, where pallets could be carried on cassettes, similarly to how forest companies transport their outgoing cargo.

Summary

The independent reefer operators and the reefer industry in general have been affected by various economic and political events over the decades. Partly as a result of these global trends, the reefer market has had its ups and downs over the years and one representation of this is to look at the development of market rates. Graph 11 charts 12-month nominal timecharter rates. One observation that we can make is that if we allowed for inflation then it should be apparent that rates have decreased in real terms. The good years and the bad years have had various effects and different actors have followed different strategies as we shall see in the chapters below. However, it is also important to note that these market rates are also influenced by the individual actors, their willingness or unwillingness to invest in tonnage, increase operational efficiency, negotiate rates with shippers, and so on. This is one reason why one cannot

41 Thanapolou, H. 2011. Bulk reefer market economics in a product life cycle perspective, Maritime Policy \& Management, 39: 281-296.

42 Arduino, G., Murillo, D.C and Parola, F. 2013. Refrigerated container versus bulk: evidence from the banana cold chain, Maritime Policy \& Management, 42: 1-18. p. 2. 


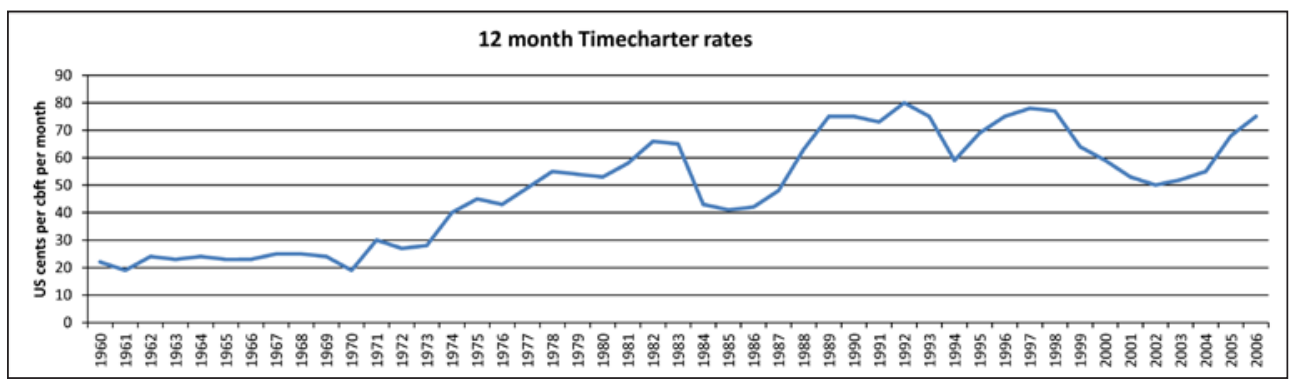

GRAPH 1112 months timecharter rates

Note: The graph is created on the base of data from "Kylsjöfart", Svensk Sjöfarts Tidning 1993/50, p. 74. Cool Facts 1989, p. 6, Cool Facts 97-98, p. 4 (data supplied by A/S Klaveness Chartering, Oslo), Cool Facts 1999-200o p. 6 and Star Reefers Annual Reports. The data in the graph is derived from multiple sources which in turn derive their figures by different methods, it should be regarded as indicative rather than precise.

neglect taking an individual perspective of the independent reefer operators, apart from seeing them as a collective phenomenon.

Returning to the graph, the stability in the 1960 s can be explained by the continued regulation of shipping conferences. The rise in rates during the 1970 s was a result of several factors, a modest rise in refrigerated trade is one of them. An important factor is the scrapping of liner tonnage with reefer capacity. This created a "gap" which the reefer industry successfully made the most of and many new vessels were built. The effect of the global recession following the oil crises impacted heavily on the reefer industy in the mid 1980s and this contributed to a decline in market rates. Some excellent years in the late 1980 s fuelled ambitious newbuilding programmes which in conjunction with the competition from the container lines created an overcapacity which contributed to a decline in the late 199os. This led to a gradual scrapping of the specialized reefer fleet and a sharp decline in reefer newbuildings, which has continued until the present day. 
PART 2

The Independent Reefer Operators 
In this part we describe the protagonists of our study - the independent reefer operators. Some of them began their operations as independents while others diversified from being a liner company or a shipper. 


\section{Salénrederierna}

Sven Salén ${ }^{1}$ was born in the Swedish city of Borås in 1890 . He finished his studies at the business school in nearby Gothenburg in 1910. Salén continued to study languages and international business and landed his first job at Göteborgs Handelsbank. However, only a few years later in 1915, Sven Salén bought his first ship. Apart from his interest in shipping, he was a professional sailor, who would later in his life compete in two Olympic Games. He was also interested in music and one of his best friends was the Swedish troubadour Evert Taube. In 1916, Salén bought another two ships, which carried pulp to Spain and wine on the return voyage, cargoes that quite accurately coincided with the comparative advantage of each of the two countries. Still, the records tell us that Sven Salén, at the end of the First World War was back at the starting point, with no ships and not a lot of money. In the early 1920s Sven Salén got back into business, freighting paving stone from Bohuslän to Gothenburg.

\section{A Fruitful Relationship}

Because of Sven Salén's interests in sailing, he met the slightly older Norwegian Carl Matthiesen at the sailing club Göteborgs Kungliga Segelsällskap. Not only did they share this interest, they also shared an entrepreneurial streak. Unlike Sven's father who was a public official, Carl's father, Christian Matthiesen, had started a lumber business in the last decade of the 1800 s. The story goes that on a train ride from London to Newcastle, Christian met with the British banana importer A. Roger Ackerley. Inspired by this meeting, Christian got an idea, and soon he produced wooden boxes for the British company Elders \& Fyffes, partly owned by the banana giant United Fruit, in exchange for the sole rights to import bananas to Norway. The commercial activities started in 1905, when 3

1 The early parts of Sven Salén's career and Banan-Kompaniet are described in Sjöberg, S. 2007. Saléns: till rors i tre generationer, Stockholm: Salénia, Lindström, A. and Malmberg, G. 2015. Svensk Sjöfartshistoria i storm och stiltje, Göteborg: Breakwater Publishing, pp. 124-132. The history of Banan-Kompaniet and BAMA (the company founded by Carl Matthiessen) is mostly documented in company materials, for example AB Banan-Kompaniet 1909-1999, available at <http://classic-web.archive.org/web/20080605050627/> <http://www.banan-kompaniet. se/goar.htm > and the corporate website of BAмA, see for example <http://www.bama.no/ om-bama/bamas-historie/1905/>. 
tons of bananas arrived in Norway. Christian would soon get the nickname Banan-Matthiessen.

Christian's banana business grew rapidly. In order to expand it further, Christian's son Carl, at the age of 23, was sent to Gothenburg, $300 \mathrm{~km}$ south of Oslo to explore if the Swedes would have a taste for bananas. In 1909, Carl established The Banana Company AB, which soon changed name to the betterknown AB Banan-Kompaniet. At that point in time the banana was almost unknown in Sweden, as unknown as it had been in Norway just a few years earlier. The first banana cargo arrived at Gothenburg in 1909 all black and frozen, and only a small amount of the sorry shipment could be sold. The bananas which arrived in a good state were well appreciated, but most bananas that arrived at Swedish ports were too ripe, frozen, or damaged in other ways. Since the Swedish market was interested in bananas, Banan-Kompaniet built up a logistical operation with their own quays to ensure fast distribution, since there were no cooling houses at the time. But the core problem remained - the bananas that arrived at the quay were already damaged.

Carl was therefore looking to improve maritime banana transport. Sven Salén was a suitable candidate. Carl Matthiessen's knowledge of and connections to the banana industry complemented Sven Salén's knowledge of shipping. Together they decided to develop the import of bananas to Sweden and Scandinavia, taking on more control of the maritime transport than previously. Sven chartered in the ship Caledonia in 1922 to transport bananas from Rotterdam to Malmö and Stockholm². Sven and Carl established a line Rotterdam-Ghent-Antwerp-Stockholm, serviced by three ships, as well as Rotterdam-Gothenburg-Oslo, serviced by two ships, what we today would call a feeder service. To Rotterdam, the bananas were delivered with United Fruit's banana carriers.

\section{Brokers: From Klaveness to Orion}

Torvald Klaveness established his company in 1946. His family had a background in shipping and his wife's father was the head of Banan-Matthiesen, who in turn was connected to Sven Salén. He started brokering reefer ships and also bought the reefer Balao, built at the Drammen shipyard $^{a}$. In the early 1960 , he focused on brokerage rather than ship-owning, in order to not be exposed to the vagaries of the shipping markets.

2 Salénnytt, 1968/1. Salénnytt is the corporate magazine of Saléninvest, aimed primarily at employees but also open to any person interested. It was published from 1968 to the bankruptcy in 1984 . 
Klaveness had employed our respondent Alv Thomassen as its sole reefer broker already in the 196os, but the business grew to the point that by the mid-199os, there were seven. Thomassen recalls that in the early days the focus lay on finding tonnage for a particular cargo and that this later changed to the reverse, that is to say, find cargo for a particular ship. Klaveness was an international operation that worked with both Lauritzen and Salén, despite their rivalry, and also the banana companies.

During the late 199os the upper management of Klaveness decided to sell its reefer brokerage arm to RS Platou. The brokers were unhappy with this decision and instead decided to start their own operation to be known as Orion. They approached Jan Olaf Tonnevold, a former investor in the reefer segment to be a part-owner.

To kick off the venture, Orion received five or six vessels to exclusively manage from Tonnevold. In the early 200os, business was good, but the profit went down in 2006 and 2007. Because of the decline and consolidation of the independent reefer operators, many brokers started to leave the reefer segment. Orion experienced that the spot market, which was particularly important to the brokers, had shrunk. Seatrade and Green Reefers also started to use in-house brokers. Furthermore, Trade Winds reported that "Reefer brokers have been forced to stand aside as exporters and ship owners tie up tonnage themselves"b. Therefore, the three brokers Espen Harr, Peter Oyen, and Morten Saetre wound up Orion but continued to do business separately. Orion's demise meant that there were few reefer brokers left in the market, Ocean Reefer Services in the U K was one.

Notes: a Borgen, P.O. \& Heieren, R. 2011, Made in Drammen: industrihistorie fra en østlandsby med hovedvekt på perioden 1870-1970, Drammen : Drammen Rotary, p. 123. Available at: <https:/www.drammen.kommune.no/Books/made\%2oin\%2odrammen/files/ assets/basic-html/index.html\#page1>; b "'Madness' reigns in the reefer zone". Trade Winds 29 January 2010.

Soon after the business was established, Sven Salén started to invest in tonnage for the new lines, since there was a lack of suitable tonnage that could be chartered in. The first ship was the steamer Chr. Matthiessen bought in 1923 which was rebuilt for transporting bananas, and she was followed by three more ships bought in 1926-1929: Jamaica, Sigrid Matthiessen, and Sverre Nergaard ${ }^{3}$. Moreover, they were upgraded to ventilated fruit carriers and heating equipment and insulation were installed to prevent the cargo from chilling injury in the

3 They all had an operating speed of 10-12 knots, were of about 1300-1500 dwt. 


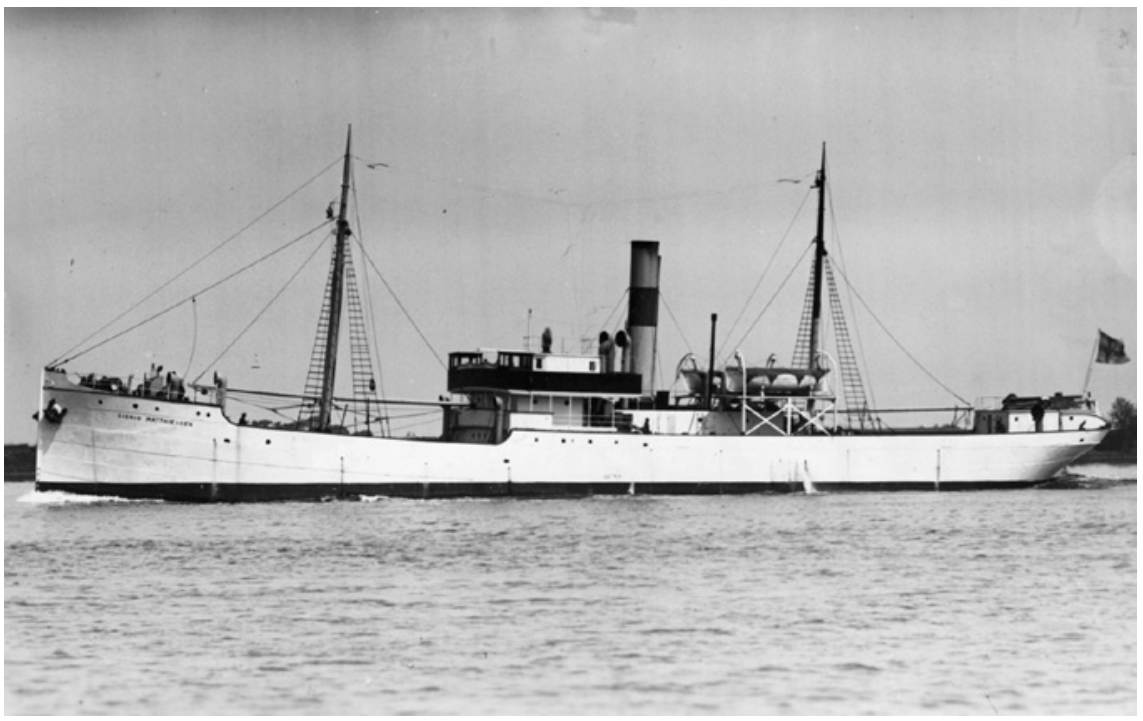

FIGURE 4 Sven Salén started transporting bananas from Rotterdam and Bremerhaven to Scandinavia with small ventilated fruit carriers like the Sigrid Matthiessen PHOTO: LINDENBORN, M./ SJÖHISTORISKA MUSEET

winter months. The relatively short distances and the cool climate made the operation viable but lacking refrigeration the spoilage was nevertheless considerable. Bremerhaven was soon added as a port where Salén picked up bananas.

Coinciding with this development of logistical operations, the Swedish banana consumption grew rapidly from 465 tons in 1920 to 10417 tons in 1930. This was of course not only due to Salén's shipping operation. Banan-Kompaniet promoted the banana through advertisements of various kinds, and they developed their land facilities: in 1928, Banan-Kompaniet built a terminal at Stockholms Frihamn, comprising their new headquarters, new cold storage facilities, repacking space, and exclusive rails to carry the cargo to the hinterland.

Given Banan-Kompaniet's position as the sole importer of bananas and the success of their product, it was time to invest. In 1931, the first newbuilding was delivered to the company - a ventilated fruit carrier called $R H$ Sanders, that was rebuilt in 1932 with a refrigeration plant. During the 1930s, an important financial connection was established with Jacob Wallenberg and the Enskilda Bank, which became Salén's main lender for the procurement of new vessels. The RH Sanders was not used on Salén's lines but chartered to an Italian shipping company for transport of bananas from Somaliland to Genoa. During a voyage, she was struck by fire and scrapped after only two years in operation. 
During the 1930s, Salén continued building the fleet with 20-30-year-old, second-hand ships, for example Lillie Matthiessen, Sandhamn, Carl Matthiessen, Banana, and others.

The fruitful encounter between Carl Matthiessen and Sven Salén had kickstarted a new venture which replaced the third-party operators' lines with new lines with dedicated fruit carriers. They were struggling with technological issues and a lack of know-how regarding how to best carry bananas from the Continent.

Sven Salén, now confident in his shipping competence to transport bananas short sea, decided to extend his operations and start his own banana imports from Central America. He ordered the reefer Sandhamn ${ }^{4}$ at Öresundsvarvet, Landskrona, but unfortunately the building process coincided with the inception of World War II. Banana imports were discontinued and the ship was laid up upon delivery in 1941.

The banana trade was reestablished in 1945, when a cargo of 2000 tons of bananas was imported from the Canary Islands for resale to the Soviet Union. At this point, Sven had become the sole owner of Banan-Kompaniet, while Carl stayed on as the managing director. To fulfil the objective of importing bananas across the Atlantic, Carl Matthiesen went to the us to negotiate with United Fruit, the largest banana company in the world, while Sven Salén chartered in tonnage for the trades across the Atlantic. At this time Carl and Sven had a good reputation at United Fruit - Carl being not only the son of BananMathiessen but also the one who developed the Swedish market, and Sven as a competent ship-owner. Since the encounter between Carl and Sven, more than 20 years had passed. It's also likely that with anticipated but uncertain postwar growth, United Fruit saw the benefits of augmenting its capacity with third-party tonnage. Wartime tonnage losses and the high capital cost of owning all its vessels are also relevant factors. In any case, United Fruit was willing to let Salén transport some of its transatlantic quantities.

Salén's own ship, the now four-year-old Sandhamn, was put to work carrying bananas. In 1946, she arrived in Gothenburg from Puerto Armuelles in Panama. But at the arrival, disappointed stevedores saw that the cargo was already turning, in other words, maturing. The reason, according to the captain, was that Sandhamn had just carried apples from Australia and that the fruit had

4 It had a capacity of $183000 \mathrm{cbf}$. 
emitted ethylene gas, causing the bananas to ripen. All efforts to ventilate were in vain since the gas had made its way into the insulation in the cargo holds. To save something of the valuable cargo, urgent measures were needed. The cargo was transported to Stockholm, and the edible bananas were packed in boxes and sold, while the others were thrown on a barge and disposed of. When Sven Salén saw the cargo, his facial expression was allegedly unchanged. From Carl Matthiessen he had learned how to look stoic in the face of rotten bananas. This is just an anecdote, but points to a more general assessment of Sandhamn - that it was not a total success from a technical perspective ${ }^{5}$.

Salén and Mathiessen had developed a functioning transport system in Northern Europe and took the first steps to develop a Transatlantic trade in the 1940s. The technological competence of Salén was fair, but nothing compared to that of United Fruit. But with this partnership with United Fruit, Salén was well-positioned for the decades of growth to come.

\section{Atlanttrafik}

Atlanttrafik was another Swedish specialized reefer company that was set up and owned by shipping liner interests: Broströms and Trelleborgsa. Both owners had planned to enter the segment and decided to collaborate. Six reefers were delivered from 1946 starting with the Blue Ocean, followed by two more in 1953. During the 1960s, the Sea class, comprising five larger sister ships to Salén's Hispaniola were delivered ${ }^{b}$. At the time Atlanttrafik started a line carrying meat from Australia to the us East Coast and general cargo back. Another four, significantly larger, vessels were added in the 196os to service this line. They were operational until 1974, when Atlanttrafik bought three partly containerized cargo vessels with reefer container capacity.

Note: a "En svunnen epok: Kylfartygsflotta under svensk flagg". Svensk Sjöfarts Tidning 1987/47, p. 14-19 and "Den svenskflaggade kylfartygsepoken". 1987/49, p. 17-21; b The Blue Ocean had a capacity of over 200000 cbf and did 17.5 knots at banana draught, while the Sea class had a cargo space of $270000 \mathrm{cbf}$ and a speed of 18 knots.

5 The four cargo holds were of very different sizes and the refrigeration system struggled to cope with the largest one in particular. The air circulation was horizontal and at about fifty times per hour was less than optimal and the open brine refrigeration system caused excessive corrosion. 


\section{The Route to Global Leadership}

In the 1950 s and $1960 s^{6}$, global trade developed in all cargo categories, and refrigerated and frozen products followed the general development. Salén was well positioned in the market with a burgeoning business relationship with United Fruit and contracts regarding other types of cargo.

As presented in the previous parts, Salén had already embarked on limited in-house technological developments that led to the newbuildings $R H$ Sanders and Sandhamn. However, the relationship to United Fruit would dramatically accelerate Salén's technological competence. The close relationship between United Fruit and Saléns and the mutual trust that had been established led to the latter gaining access to the drawings of United Fruit's reefers in the late forties. Saléns could also study and inspect the ships as much as they liked. This knowledge-transfer enabled Saléns to catch up in technology and its next newbuildings reflected this.

These were the Arawak class consisting of five ships built in 1952-1956 at three Swedish shipyards? They were designed for banana transports from Guatemala, Honduras, and Colombia to Rotterdam, Bremerhaven, and occasionally Gothenburg. A round trip took five weeks and the backhaul was generally in ballast. These ships were slightly larger and faster than the Sandhamn. They featured a patented air circulation system developed at United Fruits and the cargo holds were designed more uniformly to make refrigeration as well as loading easier ${ }^{8}$. The vessels could also satisfactorily handle frozen cargo, unlike Sandhamn.

6 This part is based on Sjöberg 2007, and articles in Salénnytt (for example in Salénnytt 1968/2, Salénnytt 1968/4, and Salénnytt 1974/1, p. 2). and Svensk Sjöfarts Tidning (for example information about Swedish reefers from Svensk Sjöfarts Tidning 1987/47, pp. 16-19, and Svensk Sjöfarts Tidning 1987/49, pp. 17-21). Technical information, as well as insights into the crucial technology transfer from United Fruit, are based on the document Saléns 80.08.10 by Carl-Olof Anderson. Some points have been picked up from a short document written by Tony Breach (former Port Captain in Port Hueneme) as well as in conversation with Ralph Mohlin and Åke Jonsson at Cool Carriers.

7 Three ships were built at Eriksberg, one at Götaverken, and one at Ekensberg.

8 The Arawak class measured $240-255000 \mathrm{cbf}$ and travelled at a speed of 18 knots on banana draught. The air circulation system was the so-called Robson system developed by the United Fruits refrigeration expert of the same name and patented in 1931. The air was circulated through the cargo vertically from bottom to top, rather than horizontally. Evenly distributed cooling in a cargo space, important for temperature sensitive cargo, is achieved by generating a slight excess of cold air pressure in the floor space. The number of air circulations per hour was also improved. The refrigeration system was closed and thus less prone to corrosion. The cargo holds were of a more uniform size making refrigeration as well as loading easier. 


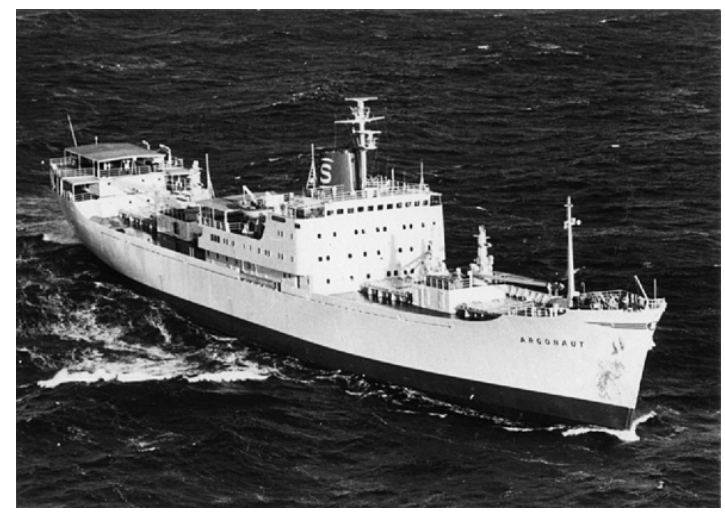

FIGURE 5

Salén expanded its fleet and incorporated new innovations with each series of newbuildings. The Argonaut, one of the A-series, was built at Eriksbergs Mekaniska Verkstad, Gothenburg 1964. Rated at 19 knots, it was 149 metres long PHOTO: UNKNOWN/ SJÖHISTORISKA MUSEET

Given the competence that Salén had come to acquire within the field of refrigerated transport, it embarked on a strategy to continuously renew its tonnage and incorporate improvements as a way to stay ahead of the competition. The tonnage renewal was primarily aimed to increase efficiency and cater to the growing transport and quality demands of United Fruit. The A-series, Bseries, and San-series all mirrored these objectives. In 1962, the fleet comprised about 35 ships, but by the end of the 196os it would be over 100 .

The six ships in the A-series, starting off with the Atlantide in 1960, were proudly described as the largest banana carriers at the time. An innovation of the last three ships in the series, was that cranes at each hatch replaced the derricks that had always been there in the past. Yet another innovation was an automated refrigeration system which reduced the need for crew for monitoring. This system proved itself to the extent that several of the earlier vessels were retrofitted. Developments on the refrigeration side were the result of collaboration with the Swedish refrigeration company Stal. Salén thus successfully tapped into Swedish industrial know-how, similar to Lauritzen's relationship with Atlas. The close working relationship between Saléns (and its successor Cool Carriers) and Stal continued all the way into the nineties. Simultaneously, the B-class was built for Salén in France ${ }^{9}$ - the first reefers built by Salén outside Sweden. The names of the ships, the Bolero, Barcarolle, and Ballade, were inspired by music, a strong passion for Sven Salén.

In 1967, a series of four "San" ships were built, San Blas, San Bruno, San Benito and Tasmanic at Eriksberg shipyard, that at $408000 \mathrm{cbf}$ were slightly larger than the A's. Apart from new developments in refrigeration technology ${ }^{10}$, these

$9 \quad$ They were built in 1961-1962 at the Chantier Naval de la Ciotat.

10 The compressors in the refrigeration system had been of the reciprocating (or piston) type in previous vessels but the availability of reliable screw compressors led to them 
were the first ships that were not adapted for carrying bunches of bananas, since the banana companies had started packing bananas in boxes. As a side note, because of this, the banana branding was carried out in the production areas, which led to United Brands establishing a common brand for all markets from 1967: Chiquita. Furthermore, the San ships were improved regarding hull design. They had a bulb which improved their resilience to storms and large waves. This became obvious on the first trip of San Benito, which left Gothenburg for Wallhamn, loaded 140 cars, and sailed for Halifax. The trip to Halifax was unproblematic, but when the ship was heading from Halifax to Guayaquil in Ecuador, a severe storm broke out. The captain reported that the ship handled it better than the A-class vessels. Still, the speed of the ship through the storm was no higher the 5-7 knots. It reached Guayaquil 21 February, slightly less than a month after leaving Gothenburg, and loaded about 200000 cartons of bananas.

This fleet expansion was coupled with market development. Positioned with modern reefers for United Fruit's traffic, Salén also had the production means to serve a wider customer base. Not all of Salén's fleet was constantly tied up by United Fruit's cargo flows, which led to diversification and business development in the 1950s and 1960s. In the 1950s, Salén began transporting bananas from West Africa to the Soviet Union, and it was also during this decade when the transport of apples and pears from South America, and also from China, became significant. The 196os meant a focus and penetration of the reefer traffic to the Far East, with fish, meat, and fruit. The first cargo to Japan was a shipment of squid and red snapper from the Canary Islands in 1961 with the ship Hispaniola. Salén became a key partner to Japanese fishing companies who fished in the Atlantic. Since Salén's ships could carry the produce back to Japan, the utilization of the trawlers could be maximized. At this point in time, Japanese fishing companies still had limited transport capacity. This also led to the Japanese getting a taste of Salén's sleek, white, seemingly profitable reefers. Morover, Japan had sourced their bananas from Taiwan, but in the early 1960 s it gradually opened up for banana imports from Ecuador, and in 1963 the import obstacles were removed. Salén was well-positioned and became a main transport provider for bananas to Japan from Ecuador. A particularly exotic cargo from Salén's perspective was the shipments of whale meat from the Japanese whaling vessels near the Antarctic to Japan, and there are even reports about a cargo of exotic animals - a kind of Noah's ark.

being introduced on the San's. The moving parts in screw compressors only rotate and this generally leads to easier maintenance. 
Transatlantic, a large Swedish shipping company, and Salén had for a long time collaborated in the reefer trades and in the early 196os they decided to build ships together to use them on the common trades. Some ships were from the A-series. In 1968, there were six ships in the jointly owned company Transal, and it was reported in Salénnytt that about $25-30 \%$ of all the fruit from Australia to Europe was transported with the company's tonnage ${ }^{11}$. A new company was set up in Australia to handle relationships to Australian growers and explore new market opportunities.

In the mid-196os a new collaboration was started with Sunkist, an exporter of citrus. In 1964, 200000 boxes of citrus were transported for Sunkist, a volume which grew from year to year. A main trade was to European continental ports via St John in New Brunswick, Canada. The business opportunity for Salén arose since the liner conferences could not guarantee delivery to the consumer markets on Mondays, which led to opportunities for reefers, which could offer a flexible service that suited the market and was more customerfriendly than the incumbent liner companies.

Towards the end of the 196os, the core of the reefer division was transport of bananas from Central America to the European continent. Other main trades were fish transports from the Atlantic to Japan, meat, fish and fruit from China to Mediterranean and Baltic ports, and meat and fruit from Australia to $\mathrm{Eu}-$ rope.

During the 1950s and 1960s, the reefer division expanded rapidly, but Salén also grew in other business areas. In the 1950s, the company invested in oil tankers, which was a new and very profitable business area throughout the $1950 s$ and 1960s. In the 1960s, investments were made in the dry cargo segment. This forceful expansion is partly attributable to the entry of a new CEO, Sture Ödner, when Sven Salén passed away. Sven Salén's sons Sven and Christer Salén took over as overseeing owners, but Sture Ödner was a strong CEO with ambitious plans to expand. The company also didn't want to be entirely dependent on the reefer segment. 
The reefer division had expanded to the point that it was operating around 70 ships in $1968^{12}$. Salén owned part of the fleet themselves, but many ships were held by other owners and operated by Salén.

TABLE 1 Salén's owned reefer fleet in 1968

Antigua

Antilope

Arawak

Argonaut

Ariel

Atitlan

Atlantide

Ballade

Barcarolle

Bolero

Carib

Cayman

Hispaniola

San Benito

San Blas

San Bruno

An employment ad tells us about the competences needed at the expanding reefer division in 1968 . We see that the division was highly international and that trips abroad were common practice. Language requirements were therefore of utmost importance. Salén was further looking for people with good schooling, preferably an academic background. It was furthermore stated that the business of the division was highly dependent on thorough and precise calculations. As a final note, it was written that the industry was undergoing a

12 The rest of the narrative about Salén is based on contemporary articles from Salénnytt and Svensk Sjöfarts Tidning as well as interviews with key personnel who were employed during the period. Some access has been granted to archival material, for example marketing materials and public information about Salén Reefer Services. 
shift from conventional handling of cargo to a modern way of handling, and therefore a person with cargo handling know-how was sought ${ }^{13}$.

Due to the variety of transport requirements, seasonality, and the constant will to increase utilization of the ships, scheduling was a core function in the reefer division. Described as a "superhuman" task, computerized support was sought for the scheduling ${ }^{14}$. In the early 1970s, a computer was installed and it generated suggestions about what ships to employ where. According to the scheduling staff, about $80 \%$ of the computer's suggestions were useful. These archival traces show how Salén discursively positioned itself as an advanced operator with skilled personnel with advanced technological support systems.

But materially, there were also developments. The end of the 1960 and early 1970 sere marked by developments in two customer relationships. On 1 July 1969, Salén took over the chartering activities of United Fruit and the new company was called Salén Reefer Services. Its CE O was Claes-Henrik Zethelius. This led to a strengthening of the competence and know-how in Stockholm. From the start SRS employed 125 reefers, which was a much larger operation than the reefer division was used to. The company reorganized into two parts: contracts and tramp. The contract division was related to United Fruit. But the tramping division was also gradually moving towards more long-term contracts.

The relationship with Sunkist also intensified. A new contract was signed in 1969 between Sunkist and Salén for transports from Long Beach to Japan and Hong Kong. Salén, despite its higher price, managed to outcompete the liner conferences with which Sunkist had shipped most of its produce before. From the sources, the discursive positioning as a competitive, modern, new entrant in contrast to the traditional liner conferences is clear. From January 1970, the contract comprised 40 shiploads per year. The first shipload was taken with the Bolero. Sunkist preferred way of cargo handling, namely pallets, and their wish to also export their produce on pallets placed demands on Salén. Salén's ships could be loaded with pallets, but the ships were adapted to breakbulk cargo and the entire cargo holds could not be well-utilized if loaded with pallets. Salén and Sunkist therefore started a joint project to develop the maritime transport of palletised fruit, which would result in new classes of ships. In mid1971, a new service was inaugurated from Long Beach to Europe with palletised citrus, something which caused great interest within the industry. By the end of 1971, a new contract ensured year-round transport of citrus, although the quantities were smaller during November-February. In 1977, 100 million boxes from Sunkist had been delivered by Salén's ships.

13 "Salérederierna söker personal till Kyltrafikavdelningen". Salénnytt 1968/1.

14 "VD har ordet". Salénnytt 1968/1, p. 2. 


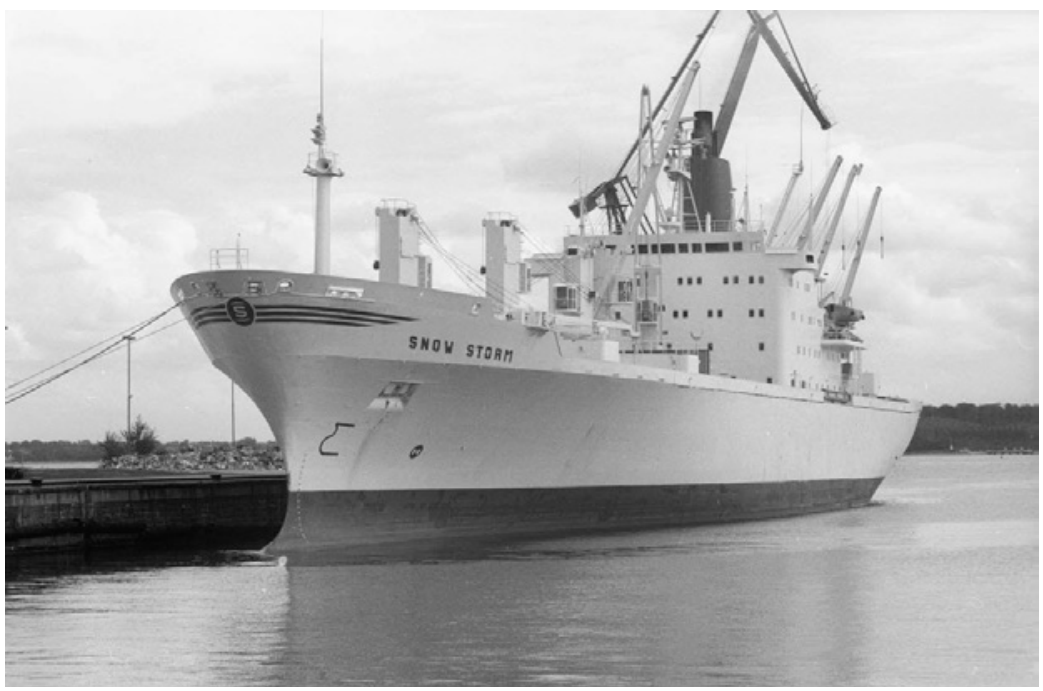

FIGURE 6 Salén's constructed eight Snow-class vessels in the early 1970s. Exceedingly large, fast and versatile, they are also fondly remembered as beautiful ships. Scheerhafen, 1975 PHOTO: MAGNUSSEN, FRIEDRICH / STADTARCHIV KIEL

At the intersection of these two relationships, a new series of ships was built. Together with United Fruit, Salén ordered eight Snow ships at the French shipyard where the B-class had been built. But, United Fruit's plantations were ravaged by hurricane Fifi, and United Fruit pulled out of the deal. Salén had to take all the eight ships, but fortunately the Franc was devaluated, which led to Salén getting the additional four ships for much less than expected. The Snow vessels were indeed state-of-the-art as their longevity proved ${ }^{15}$. Marine enthusiasts warmly reminisce about the beauty of these vessels. They were also very large at a little over 610 ooo cbf. They were fast, boasting a speed of 23 knots, and were frequently called kyljagare, refrigerated destroyers. These vessels had five hatches and 22 decks of which 18 were isolated from each other resulting in the ability to manage a wide range of cargo with differing requirements in refrigeration. The advent of palletisation was coupled with the introduction of forklifts on reefers and their weight had the effect of breaking the gratings that were carefully designed to regulate the airflow. With this in mind the gratings were strengthened. Compared to previous vessels, the Snow's had more advanced automation in regards to refrigeration; computerisation also was seri-

15 In later years these vessels were modified to rationalise their pallet-intake when they were owned and operated by Holy House Shipping. 
ously considered, but ultimately not implemented. The Snow vessels may have been state-of-the-art for their time but they also represented a first attempt at catering for the palletised trades, in other words the Sunkist trades. In a sense, the Snow ships are a solution to the requirements of palletisation, but without compromising the possibility to take more conventional cargo.

Snow Flake's maiden voyage was to Cape Town where she was loaded with the biggest cargo of apples, pears, and grapes that had ever been loaded on a Salén vessel in South Africa. Two weeks later part of the cargo was discharged in Hamburg, and some days later in Southhampton ${ }^{16}$. Snow Flower and Snow Land sailed for Long Beach to load palletised citrus. These state-of-the-art ships were delivered to a market that was experiencing a downturn.

\section{A Market Downturn and Some New Players on the Reefer Scene}

The market had turned down in the end of the 196os due to problems that Salén had never experienced before. In Salénnytt, the employee magazine, in the end of 1968, Sture Ödner wrote that "it appears that some ship-owners, lacking other investment opportunities, have decided to build reefer ships, without knowing well the conditions for employment of these vessels. This has led to that there will be a great oversupply of reefer tonnage, which is offered to low rates. Today you can charter reefers of foreign flags to not too many percent over the daily operation costs of reefers under Swedish flag."17 This is of course discursively constructing the other ship-owners as unknowledgeable outsiders breaking the informal norms of the industry.

Maritime Fruit Carriers (MFC) was the company that Ödner particularly had in mind. Starting out as a fishing company, the top management made the most of Israeli state subsidies and Norwegian shipyard subsidies to build up a substantial fleet of reefers. But the relationship, or antagonism, between the two companies started already in 1963, when Salén was approached by MFC, who announced that they were about to build a large number of reefers and charter them out in the market. The reefer division of Salén was shocked by this development - why would anyone build dozens of ships without paying attention to the market demand? Apart from discursively constructing MFC as lacking knowledge, this is a discursive sign that the reefer market had been quite controlled, especially from Salén's perspective. Not only MFC, but also Japanese shipping companies and fisheries had started to expand their reefer

16 “Snow Flake på jungfruresa”. Salénnytt 1972/2, p. 9.

17 "VD har ordet". Salénnytt 1968/5, p. 2. 
fleets, which reduced market rates. Sture Ödner's assessment was that the rates were not good enough for newbuildings, such as the Snow vessels, but that older ships were profitable. He further stated that the advances in cargo handling might give Salén a competitive advantage ${ }^{18}$. The new Snow ships could, however, utilize the good market for non-refrigerated dry cargo. To add to the low market rates, in early 1970, bunker prices had increased which also negatively affected Salén Reefer Services ${ }^{19}$.

MFC had by the early 1970s become a severe disturbance to Salén's dominant position in the reefer market, having a fleet of 42 ships. They once again offered their tonnage for Salén to charter and this time Salén felt that it was necessary to accept. Mats Ruhne, a major figure within the industry, explains, "We included the ships into our fleet to control the tonnage". The ships were chartered in for 15 years to keep them away from competitors and to maintain Salén's dominant market position. At this time SRS was broken up and United Brands, as United Fruit was now named, went back to operating its ships. It was agreed, however, that SRS would continue to transport a large share of United's bananas ${ }^{20}$. Another reason for the United Brands and Salén's breakup of SRS was that the ships in SRS were of such a varying quality that many expected advantages could not be achieved ${ }^{21}$.

Japanese shipping companies and fisheries also entered the market at this time and they were, from Salén's perspective, impossible to collaborate with, or perhaps, control. They were subjectively perceived as having unlimited funding for newbuildings and employing an overly aggressive pricing strategy. Their lack of English made informal communication difficult. Stereotypes amplified the idea that they were irresponsible newcomers to be kept at a distance, a process of othering that delayed cooperation with Japanese actors for many years.

In 1973, the year of the first oil crisis, MFC was in particularly bad shape. It was highly financially leveraged and had also tried to profit from a high exposure to the crude oil tanker segment. In 1975, with no signs of market improvements, there were severe problems with MFC and a bankruptcy was impending. MFC ships were arrested by banks, their seafarers went on strike and Salén's MFC ships ended up on the blacklist of many customers. Salén therefore cancelled its timecharter contracts with MFC on 28 June 1975, which triggered MFC's bankruptcy. People from Salén, headed by Mats Ruhne, went to London

18 "VD har ordet". Salénnytt 1972/3, p. 3.

19 In 1970, the company bought 1.4 million tons of bunkers. With a price increase of $75 \mathrm{SEK}$ per ton from Dec 1969 to Dec 1970, the result was 2om SEK lower than expected.

20 "C-H Zethelius: En återblick". Salénnytt 1974/1, p. 2

21 “C-H Zethelius: En återblick”. Salénnytt 1974/1, p. 2 
to solve the MFC imbroglio. This work was highly successful from Salén's perspective, and more than 30 ships out of 42 could be kept within the Salén operation. Also, the legal side of the deal was successful. MFC sued Salén of 1.5 billion SEK due to the contract breach but was in the end entitled to only 35 million SEK when the case was resolved in 1978. Mats Ruhne became CEO of Salén Reefer Services following the successful handling of the MFC crisis and Claes Henrik Zethelius entered Salén's corporate top management.

In the late 196os and early 1970s, Salén had also expanded rapidly in the oil tanker segment. Salén together with the Swedish state, became the owner of the Götaverken shipyard in 1971 and became a controlling owner of Kockums Shipyard in the following year. After the oil crisis, both the shipyards and the oil tanker segment started to bleed. To avoid collapse, Salén had to get out of the shipyard segment.

Palletisation and Maximal Flexibility

As a way to convince the Swedish state to buy the remaining part of Götaverken from Salén, Salén offered to build six reefers at the shipyard. The ships were highly flexible and could load boxes, pallets, cars, and containers on and under deck. The experience of the Snow vessels taught Saléns the need to optimise deck heights and to rationalise the configuration of the Winter vessels. They had a capacity of 608 ooo cbf, almost as large as the Snow ships; there was no market demand for even larger vessels. The ships had strong cranes (with a capacity of 16 tons). They were so called open hatch ships with very large hatches in order to eliminate the need for horizontal movements within the cargo holds. Similar ships with open hatches had been introduced for the transport of paper reels in North America and from Sweden in the mid- to late 196os. Multi-pallet loaders, lifting up to 12 pallets a time, were developed for the Winter type ships, intended to increase cargo handling speed with $100 \%$.

During the 1970s, there were many discussions within Salén about the technological development of the reefer industry. Salén Reefer Services' preferred method was palletisation, which rationalized cargo handling over breakbulk handling. But although some customers were interested in palletisation, for example Sunkist, others were not. In some countries, stevedores were inexpensive and boxes were an easy to handle size, compared to pallets which required infrastructure, such as pallet trolleys, and competence. Salén Reefer Services tried to convince its customers to see the benefits of the pallet. In some cases, it worked. For example, in 1979, the first pallet of citrus was loaded from Buenos Aires. However, in an interview with Mats Ruhne in 1975 in Salénnytt, he 
stated that "Regarding bananas there has been no development the last 15 years, which is due to the advanced cargo handling with elevators and conveyor belts." Banana companies were not, at this time, interested in palletisation, since they had already found their preferred way of handling cargo - boxes, conveyor belts, and elevators. The mixed cargo handling techniques on the exporter side and uncertainty about the future way of handling cargo led Salén Reefer Services to always construct flexible ships.

Discussions were held about another form of unitisation: containerisation. Salén saw the container as a too large unit for reefer cargo, on the customer side. In other words, no customers would like a full container of some fruit, but the right unit size was rather the smaller pallet. Also, the container was much more expensive than a wooden pallet, and to move a refrigerated container inland required excess containers, since a reefer ship seldom stayed in port a long time. However, Salén closely followed the developments of refrigerated containers in order to not keep all of their eggs in the same basket. They knew that United Brands had experimented with carrying bananas in refrigerated containers since 1972, when they introduced a twice-weekly service between Cortez, Honduras and Gulfport, Mississippi, employing two small self-sustaining cellular reefer vessels. Salén was therefore eager to gain knowledge in the field. They initiated a collaboration with Sea Containers, the pioneer in containerization, and Standard Fruit. In 1981, they inaugurating a two-ship service operating between Honduras, Guatemala, and Texas. Each ship had a capacity of 325 Twenty-foot Equivalent Units (TEU ${ }^{22}$. However, containerization was only seen as interesting in short sea shipping, and Salén Reefer Services emphasised that although they were not strangers to containerization, their strategy to work with palletisation of fruit trades remained unaltered. Thus, Saléninvest discursively positioned itself as a company that was going to focus on palletised cargo - not containers, although containers could be carried on the weather deck.

During the 1970s, Salén Reefer Services also invested in port infrastructure. In 1975, Salén entered as an investor in an existing cold store in Hong Kong. In 1979, a new cold store was built in Sharjah in the UAE, by the quay in Port Khalid. And in 1980, a new fully palletised cold store was built in Eemshaven. There were also other ventures. For example, in 1981, SRs bought $50 \%$ of the French fruit importer Dunand \& Cie, which could increase the utilization of Salén's fleet.

22 Sinclair, J. et al. 1989. Refrigerated Containers, Technical paper. available at $<$ http://docu ments.worldbank.org/curated/en/618601468739777372/text/multi-page.txt>. 
In an interview, Mats Ruhne explained that in 1982, structural changes in the reefer market were perceived and McKinsey were hired to do a study about the global reefer market. According to McKinsey, SRS was considered to be quite good within its particular niche. A success factor was seen as the ability to offer various transport solutions to their clients and to continue to develop the successful palletisation concept ${ }^{23}$. The Winter ships were the core of this flexibility. Based on this analysis, more ships were ordered, the eight ships in the Spring class. Each had a capacity of $430000 \mathrm{cbf}$, which was smaller than the earlier ship types. They had open hatches, a high flexibility, and a higher container capacity - 93 Forty-foot Equivalent Units (FEU) or 215 TEU. The ships were built in three different shipyards, Koyo Dockyards, KESC and Hyundai. The ordering of the Spring vessels showed that palletisation was still the preferred concept. To get an understanding of Salén Reefer Services' discursive construction of their preference for pallets, we will quote a section in SRS brochure Keep Cool:

The problem of unitizing cargo can be solved in different ways. By simple, task-oriented systems that can be implemented without excessive cost. Or by expensive systems that are both sophisticated and complex.... A container system cannot meet the requirements for flexibility in the refrigated-goods market. Container shipments call for return cargoes, efficient ports and large investments. And these are not feasible in many of the localities from which refigerated goods are shipped. The cost of energy is another problem. The most competitive port-hole container requires $50 \%$ more energy per unit of goods than the corresponding space aboard a reefer ship. Integrated plug-in type containers require four times as much energy. But one of the biggest problems when it comes to containers is simply this: As a cargo unit, the container is too big for most consignees.... The palletised load is a better alternative than the container. The pallet system is simple and practical. If it's used consistently it meets today's demands for efficiency. In addition, it requires less investment and can thus generate much higher yields than an expensive container system. Most important of all, palletised cargoes meet the specific demands of shippers of refrigerated commodities for fast adaptation to seasonal changes and fluctuations in volume.... Which is why we are convinced that for most trades the future lies with palletised cargoes. Not with containers." 24

23 "The reefer market of the future". Salénnytt 1983/5, p. 19.

24 Keep Cool, 1982, p. 6-7. Brochure about Salén Reefer Services. 


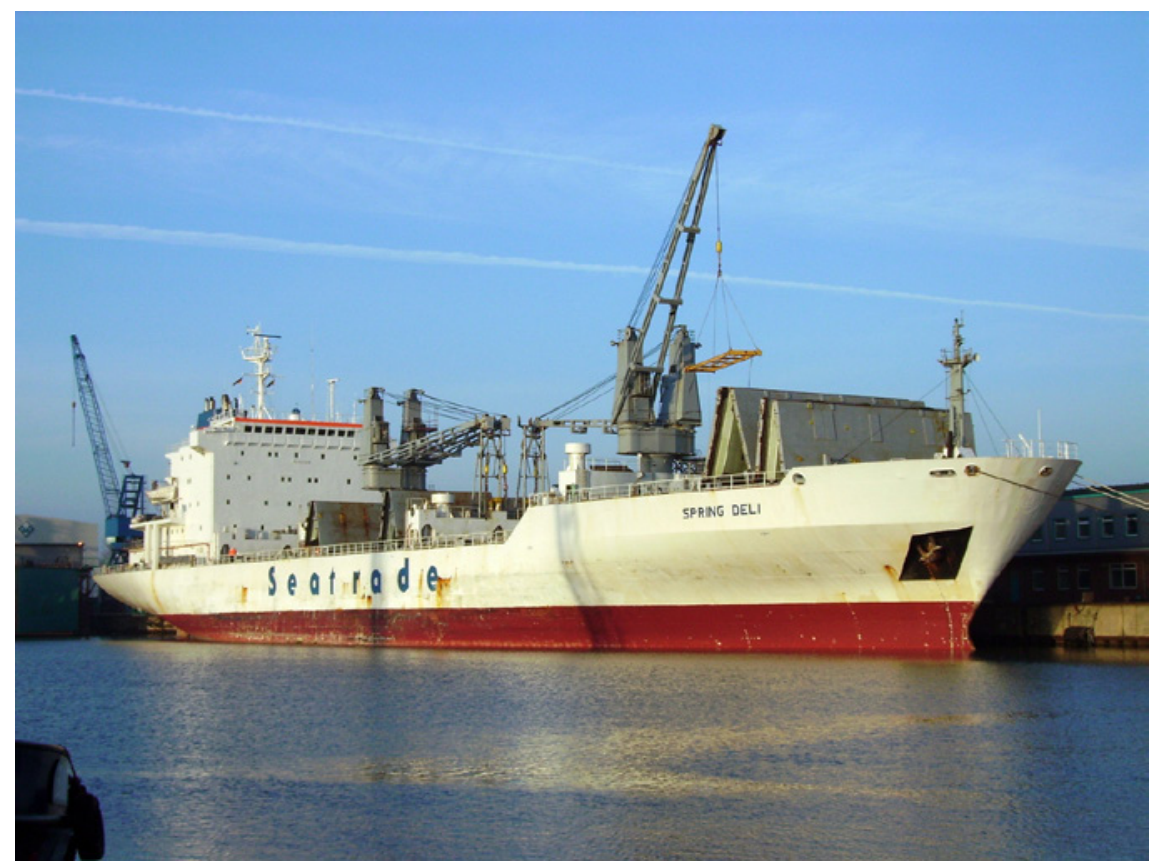

FIGURE 7 Spring Deli, previously Spring Delight, later sailed for Seatrade. Note the massive hatches folded up ondeck

PHOTO GARITZKO

When the ships were delivered, SRs controlled a fleet of 80 ships. In the same year, a new organization was created with four business areas. The only new business area was the TransPacific division which carried citrus from us west coast to Asia and containers from Asia to the us West Coast. The ordering of the Spring vessels is remarkable, since Salén was at this time undergoing a significant reconstruction. That Mats Ruhne gained the approval to purchase the vessels symbolizes the power of division managers, the perceived centrality of the reefer division, and perhaps the lack of oversight within the company.

In 1984, United Brands left Salén after a 50-year long relationship. In the end of the 1970s, Salén handled $40 \%$ of UBs traffic, although only $3 \%$ went to Scandinavia. In the early 1980 s, United Brands direct chartered ships and forced Salén to take over these ships to high charter rates in exchange for keeping the transport contract from the Americas to Europe. However, United Brands received another bid from Lauritzen, and broke the contract with Salén.

In the early 1980s, the group was diversified and divisionalised, and every year the divisions received a clean slate, and therefore did not have to take responsibility for incurred losses. During the last decades the company had 


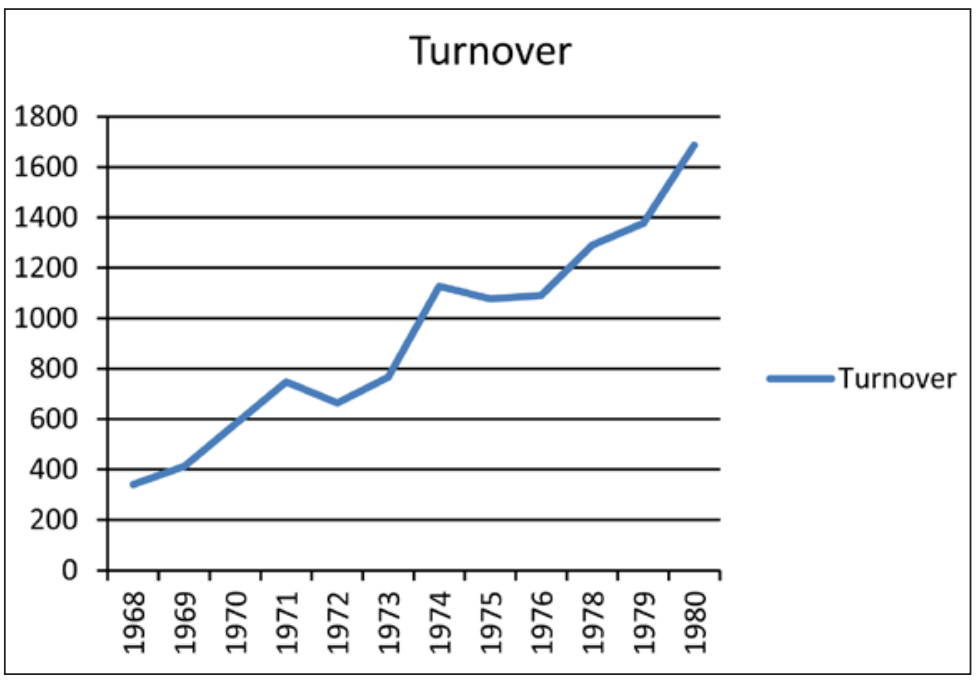

GRAPH 12 Salén reefer services turnover from 1968 to 1980 in mSEK

diversified and expanded significantly, and the investments in the shipyards had been costly, as well as the tanker division that had been bleeding since the first oil crisis. During the final years, the central management tried to sort out the situation but it was too late. The poor performance throughout the group forced the company into bankruptcy on December 19, 1984.

\section{$7 \quad$ Summary}

From a fruitful encounter between a banana importer and a ship-owner, Banan Kompaniet and later Salénrederierna first established market dominance in the Nordic countries and then gradually developed its Transatlantic business with United Fruits. In the 196os, Salén's reefer division became the world leader in maritime reefer transport. They collaborated with shippers, learned from them and developed ships and cargo handling techniques. During the years, Salén built up significant technological expertise, which was fuelled by newbuildings. To remain a market leader, new classes of increasingly modern ships were developed. The market was looking better and better until the end of the 1960s, but new entrants and significantly higher bunker costs made the 1970s difficult. In the 196os Salén described itself through discourse as a modern, high-tech, global market leader with state-of-the-art ships. It prided itself subjectively of being the biggest, of the strong relationship to the major fruit company United Fruit, and of its innovative cargo handling techniques - focused 
on optimizing pallet handling. It also discursively described the competitors as newcomers who were unknowledgeable and invested irresponsibly. The organization had the high degree of self-confidence that comes from being the market leader. Through the adverse market in the 1970 and early 1980s, Saléns continued full steam ahead to renew its fleet and develop. The results were neither sustained nor highly positive since the end of the 196os, but neither were there any major losses within the reefer division. The reefer division was never questioned within Saléns but was seen as a core area where investments should be made. However, given the liberal investment policies at Saléninvest, due to the divisionalized structure, Salén's reefer division invested significantly in the end of the 1970s and early 1980 . This is quite a different to the situation within the organization that will be described in the following section - Cool Carriers. It was a viable reefer operation that followed Saléninvest into the abyss, which is why it was possible to resurrect it so quickly. Looking ahead it might be interesting to compare this story with that of Lauritzen, which of course did not go into bankruptcy but where another event struck the reefer division in the mid-1980s - namely the McKinsey report. 


\section{Cool Carriers}

The day Saléninvest's bankruptcy was announced, it was doom and gloom for many at the office on Norrlandsgatan, Stockholm 1 . Many of the former employees at Saléninvest barely knew what they were going to do, but the management of the reefer division Salen Reefer Services (SRS) were completely prepared. Mats Ruhne and his closest executives, also known as the Five, had feared that the end was near for Saléninvest and had made plans to quickly revive the reefer division, in case of a bankruptcy. In November 1984, a company was created called Salén Supporters. Officially, the investor was Gyllenhammar and Partners, but Stenbeck and Sven and Christer Salén were also involved. There was a feeling that the reefer division was the genuine Saléns, that it was world-leading, and that it could not be allowed to fall just because other divisions had failed.

When the bankruptcy was a fact, the backup plan was activated and a new reefer operation was in place the day after the bankruptcy. A person who was there from the start in the almost identically-named new company, SRs Reefer, says that "we found it hard to keep a straight face among all the sadness. We felt an incredible joy to work. We got up and rushed to work while everyone else at the defunct Saléninvest were staring into the walls". Everyone in the reefer section knew what had to be done. When a shipping company goes bankrupt, there are always gold-diggers appearing to see how they can profit from the mess. SRS Reefer needed to win the race against these gold-diggers. In some way, perhaps SRS Reefer was lucky regarding the timing of the bankruptcy. While many reefer companies checked out in order to celebrate Christmas and New Year, at SRS Reefer it was full steam ahead.

1 This part is based on annual reports of Cool Carriers and its owners, the annual review of Cool Carriers called Cool Facts, newspaper clippings from Swedish and international newspapers, articles in Svensk Sjöfarts Tidning, archival material from Mats Ruhne's private archive, as well as a large number of interviews with management and employees of Cool Carriers as well as their owners. We have also made use of already published literature about the post-Salénbankruptcy businesses such as Sjöberg 2007, Sjögren, H. 1997. Spelet $i$ Saléninvest, Stockholm: Ekerlid, Fagerfäll, R. 1999, Företagsledarnas århundrade. D. 3, 1967-20oo: från Werthéns förvärvsstrategi till Barneviks globala nätverk, Stockholm: Norstedts., Lennerfors, T.T. 2009, Stockholmsrederierna - Ägandet och nätverkens betydelse för tanksjöfartens utveckling $i$ Stockholm 1980-200o, Göteborg: BAS \& Breakwater Publishing. Müller, L., Hallén, P. and Lennerfors, T.T. 2016. Handel och sjöfart, in Ekström, S., Müller, L., and Nilson, T. 2016. Sjövägen till Sverige: Från 150o-talet till våra dagar, Malmö: Universus Academic Press, pp. 69-120. 
A "command centre" was built up in Saléninvest's offices. The SRS fleet list was posted on the wall next to a list of SRs' customers. Half of the employees started phoning around to the shipowners to convince them to reemploy the ships within SRS Reefer. Some owners, however, were sitting on contracts with good charter rates, and these were renegotiated after the bankruptcy. Many shipowners were involuntary, for example banks and the Swedish state, and those often agreed to let SRs Reefer commercially operate their ships. The second half of the employees phoned around to customers and assured them that everything was business as usual. One might wonder how many customers actually realized that Saléninvest had gone.

While the Swedes were preparing for Santa Claus and the Swedish tradition of watching Donald Duck on Christmas Eve, the command centre was imbued with cigarette smoke and the smell of strong, very strong coffee. Through the door of the office and into the room stepped the CEO of SRS Reefer, Mats Ruhne, who had jogged along with his dog to the office. It was freezing cold and both Ruhne and the dog were covered with ice. But the staff remember that Mats Ruhne infused courage and work enthusiasm into the group. They shared this task, there was solidarity, they sacrificed their leisure and their families in order to save the business, and their jobs.

SRS Reefer, soon renamed Cool Carriers, was devoted to operating but not owning ships. In the Swedish Shipping Gazette in January 1985, Christer Salén explained that the new reefer operation "shall own vessels only exceptionally and this means that we will operate with a much lower risk profile. It will not have the same exposure [to risk] as in the old company [Saléninvest]"2. The company tried to position itself through discourse as more of a "software" company than its predecessor. More brokering, more an organizer of pools, operating vessels for others, using some chartered-in tonnage. It was disclosed that the company would also focus on modern ships with large hatch openings (i.e. the Winter and Spring vessels), the right dimensions of the holds, and right angles, all to improve the efficiency of loading and unloading.

Behind the scenes, the Five went around to banks and made deals in order to secure tonnage for their operation, because they knew that despite the discursive positioning as a software company, without control of tonnage the company was nothing. The ownership structure of the ships was very complicated, and it has been repeatedly stated that very few knew how the whole set-up was organized. However, it is clear that the owners of sRs Reefer, in other words, those who had provided capital for the business as well as the Five, were also trying to get ownership of the hardware - the ships. It was also

2 "Saléns seglar vidare. Nytt bolag håller kylsjöfarten igång”. Svensk Sjöfarts Tidning 1985/1-2, p. 2. 


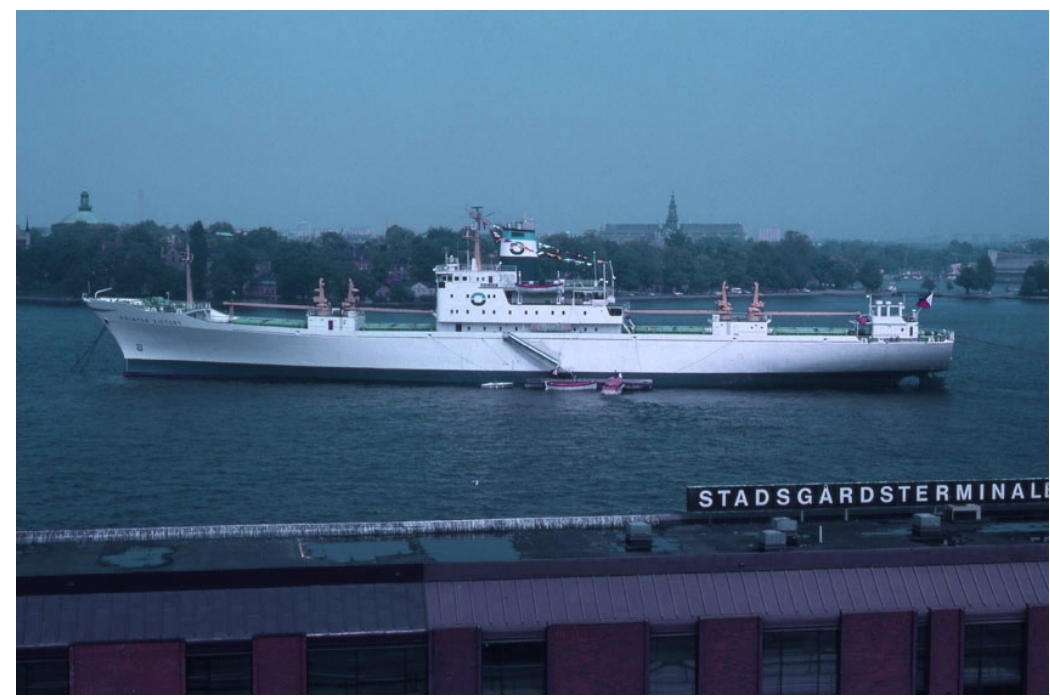

FIGURE 8 Cool Carriers managed to secure the operation of most of Salén's reefer tonnage following the bankruptcy. Pictured is the San Blas from 1967, renamed the Malayan Victory, in Stockholm 1986 PHOTO: ÖSTRING, BILL/ SJÖHISTORISKA MUSEET

shortly after the bankruptcy that personnel at Cool Carriers started to understand who was actually owning the company. An employee explains:

After the urgent time was over, after a month or so, it started to become clear to us that the Five had ownership in the company. The whole teamspirit was gone, a cold wind swept through the company. We were degraded to just workers. It was the Five and there was us. They lost the trust of the personnel.

This was the start of an increasingly collective collegiality amongst the employees, and against some of the owners. These employees started to perceive the owners as antagonists, rather than on their side. This subjective perception would strongly influence the history of Cool Carriers.

Initially the ships were operated under what was called a best effort system, i.e., that the owners of a ship got what the ship had earned minus an operations fee which SRs Reefer took. However, this could lead to one ship getting really good trades and earning a lot of money, while another ship received poor trades and did not earn anything at all. Furthermore, the best effort system could lead to owners suspecting that other owners were favoured. This could be avoided by creating a pool where all ships shared the revenue from the en- 
Seasonal Fruits Division: citrus, apples, pears and grapes to the North European continent and North America

$\begin{array}{lll}\begin{array}{l}\text { Trans Pacific Division: A } \\ \text { service with five Spring } \\ \text { vessels between Long }\end{array} & \begin{array}{l}\text { Division Tropical } \\ \text { Fruits: Bananas }\end{array} & \begin{array}{l}\text { Worldwide Tramping Division: } \\ \text { frozen fish and similar to the Far }\end{array} \\ \begin{array}{l}\text { Beach and Japan. Trays } \\ \text { of fruits and vegetables, }\end{array} & & \begin{array}{l}\text { East, chilled and frozen meat } \\ \text { from NZ, fruit from Chile, cars }\end{array} \\ \begin{array}{l}\text { refrigerated and dry cargo } \\ \text { containers, each week }\end{array} & \text { from Japan, apples from the } \\ \text { (liner type) } & \text { United States. Transport to the } \\ & \text { Middle East. Also a line from }\end{array}$

GRAPH 13 Cool Carriers' organization

tire pool ${ }^{3}$. The pool that materialized was called Leonina. The name was chosen since Leonina was considered to represent the lion's mother who protects her little lion cubs - in other words, the big, strong, experienced sRs Reefer who protected the ship-owners. This was how the management of Cool Carriers perceived of the company and how they discursively constructed its purpose. That Leonina later was discovered to be an old Biblical myth - about a lion who hunts together with an antelope - led to significant confusion about what Leonina really meant. Furthermore, in business language, Leonina could even be seen to refer to leonine clauses in contracts - clauses that are heavily biased.

Somewhat into the year of 1985, SRS Reefer had gained control over some 6o-70 vessels. A few months later, in April, it moved out to new offices outside the city at Danderyd. The budgeted revenues were 2 billion and a profit of 49 million SEK. The organization was identical to that in Saléninvest, depicted in Graph 13 .

Cool Carriers was thriving, with new contracts, such as transporting ten large shiploads of octopus to Japan in the first half of 1986, and a large banana contract from Colombia, primarily, and Ecuador to the United States in 1986. The banana contract concerned 17 million banana boxes employing 6-7 vessels. The fruit was delivered by Uniban in Colombia, shipped to Galveston, Tampa and Newark, received by Turbana (Uniban's sales company). The financial outcome of the first year of operations was a profit of 5 om SEK.

3 "All permanent ships employed in the Leonina System (i.e. not the pool's own short term tonnage) share the System's net result on the basis of (a) the ships' cubic capacity (b) the number of days in the System and (c) a factor (trade factor) which reflects the ships' suitability for the various trades which are served by the System. While there is a great number of inputs which go into the mathematical determination of these factors, the main ones reflect the ships' suitability for pallet cargoes, fuel consumption, and cargo handling facilities. [...] The trade factors are checked yearly to reflect changes in market conditions, bunker prices and also the ships' actual performance". Cool Carriers Information Memorandum December 1986, p. 4. Mats Ruhne's private archive. 
Given the successful development of Cool Carriers the upper management led by Mats Ruhne started to subjectively perceive themselves increasingly as entrepreneurs, although their ownership in the company was limited. A classical conflict between owners and managers ensued, where the principal struggle was personified as Mats Ruhne vs. Jan Stenbeck. There are a number of stories related to this struggle and it is unlikely that it will ever be established what really happened. The conflict was aggravated by all the assets that were outside Cool Carriers, namely the ships. The owners of Cool Carriers were trying to get control of the ships that were owned by banks and managed to do so. Who was invited to each deal and who was not became a core issue of the conflict, as well as who the banks think they sold the ships to - was it to a daughter company to Cool Carriers or to the owners as private persons? Another conflict concerned what company should be chosen to be an insurance provider to the new cargo insurance that Cool Carriers offered to its pool members. When the managers decided to not use Stenbeck's insurance company, this was not received favourably. Stenbeck called in auditors and claimed that Ruhne had embezzled money from the company. When the Five returned from negotiations to buy the six Winter vessels from the Swedish state shipping company Zenit ${ }^{4}$, there was a security guard with a guard dog in front of the main door, hindering them from entering.

Perfresh

The Five decided to start up something of their own ${ }^{5}$. They bought into a stock-listed company named Percal and renamed it Perfresh. Perfresh filled four main functions. First, to be a base so that they could continue working with existing customer contacts and forge new ones. Second, Perfresh intended to own ships. Right from the start, they had brought with them five vessels from Cool Carriers that were owned by the banks. The Five managed chartering and operation of the vessels. Third, Perfresh developed an import and distribution business in the fruit and vegetable trade. Previously Cool Carriers had been part owner of the Dutch fruit and vegetable importer Jan van den Brink. This company had successfully managed to build a business around small shops that sold vegetables throughout Holland. Perfresh and Jan van den Brink tried to launch this concept in Denmark, but with little success. Fourthly,

4 Zenit is described in Lennerfors, T.T. 2014. An involuntary ship owner - the background and effects of Swedish state involvement in shipping during the 1970's and 1980's, International Journal of Maritime History, 26: 702-719.

5 Part of this episode is described in "Nya kylrederiet Perfresh förvärvar första fartyget". Svensk Sjöfarts Tidning 1986/49, p. 2. 
the Five thought that the time was right to build new reefers. Perfresh developed a ship based on the knowledge accumulated within Salén and Cool Carriers and Per-Olof Oweson went to the Gdansk shipyard in Poland to negotiate. The yard initially agreed to build some ships at what looked to be a very low price. Subsequently, the yard was forced to change the deal and at this point the narrative diverges as to exactly what happened. Oweson's perspective is based upon that Perfresh had cancelled the deal while the remaining Four claim that the deal was still under negotiation. However, the broker - Christian Larsson - considered the revised higher price from the yard to still represent good value and tried to recruit investors and one of those was Oweson, who subsequently left Perfresh. The Five had become Four.

The legal dispute between Stenbeck and Ruhne continued and these highlevel conflicts affected Cool Carriers which became somewhat paralyzed. However, because of the subjectively perceived antagonism between the upper managers and the organization at Cool Carriers, the lower echelons of the organization decided to collaborate with owners not directly involved in the conflict to find a solution to the problem. They approached Bilspedition as a potential buyer of Cool Carriers, in order to find a solution to the ownership situation.

After some twists and turns, the whole package, Perfresh and Cool Carriers, was sold to Bilspedition.

\section{Holy House}

After the settlement with Bilspedition, Mats Ruhne controlled a number of vessels including four of the Snow ships. These ships became the foundation for Mats Ruhne's Holy House Shippinga, which still exists today (2018). The purpose of Holy House Shipping was to be a shipowner and to timecharter ships to operators. Cool Carriers chartered a few ships but some people at Cool Carriers still mistrusted Ruhne, so Holy House decided to approach the customers of Cool Carriers - banana companies. From 1990 to 1995, Holy House chartered their ships to Chiquita and this resulted in a confict that is notable. When the EU banana regulations were altered, the reefer market was negatively affected, and Chiquita broke the contract with Holy House two years before the end date of the timecharter. They claimed that the Snow vessels did not conform to the deck height specification. Holy House started arbitration against Chiquita, and finally won a 10m USD claim against GWF, Chiquita's shipping arm, in 1997. After all, Chiquita had signed the contract and had accepted the Snow's configuration. When the contract with Chiquita was lost, the ships were timechartered and went in traffic to Capespan (South Africa) until 2005. 
During the second half of the 1990s, Holy House expanded their fleet with second hand tonnage. These vessels were of varying age, in fact most were quite old, but the main commonality of these purchases was that they represented good value for moneyb. By 2001, the Holy House fleet consisted of 17 ships. The fleet remained stable, but after the crisis of 2008/2009 Holy House scaled down their fleet to five ships. In 2013, they bought Hansa Bremen and Hansa Lübeck and employed them in NYK Cool but later transferred them to Seatrade's pool. In 2015, they had seven reefers in their fleet, and in 2017, they had four. The strategy of Holy House over the years has been to own a fleet of well-maintained large ships, that despite their age could compete for the same trades as the major independent operators.

Note: a Written on the base of publicly available material in TradeWinds, the Holy House webpage as well as interviews with Mats Ruhne and Anna Börjesson Ruhne; b In 1996, Laponian, built in 1992, was acquired for 20-21 mUSD. Two years later Kea (built in 1982) and Kyma (1972) were bought for 9m and 4.5m, and later Kudu (1984) for 3.2m. In 2001, Holy House also purchased three 1970s-built reefers, the Selma (1979), Cherry and Morillo (both 1971) at a low price of $\$ 3.5 \mathrm{~m}$ in June. In September 2001, they bought the Pacific Star, Atlantic Star, Baltic Star and Tasman Star (all 1983) en bloc for a reported \$9.5m from Tokumaru Kaiun.

\section{Caesar Reefers}

Caesar Reefers came about as a result of Perfresh not going through with the constructions of the vessels in Gdansk as outlined previously. This was one of the most profitable deals during the last 30 years in the reefer market. Many other speculative ship-owners, with no interest in own commercial operations, invested during this period. This story exemplifies the realities of ship-owning and reefer investment.

The Swedish ship-owner and businessman Mats Arnhög was a leading investor in the consortia that took over the deal. The ships were going to be built at the Lenin shipyard at Gdansk in Poland and both Arnhög and the broker Christian Larsson had a past relationship with the shipyard. When Mats was working for the oil trader STC, STC had placed an order of six medium-sized tankers (40 ooo dwt $\mathrm{t}^{\mathrm{b}}$ ) at that very shipyard in 1979 brokered by Christian Larsson. This was not just any Polish shipyard, nor any time period, seen in hindsight. It was during the building of these very tankers that Lech Wałęsa founded the Solidarity trade union movement on 14 August 1980 at the shipyard.

Christian Larsson knew that Arnhög was an interested investor within the shipping segment, and therefore reached out to him. At first, Arnhög 
was not interested in the deal, but the Poles were persistant and after eight days of negotations in Stockholm, a deal was signed for six ships but with the right to cancel four of them. At first, the ownership consortia never intended to be the owners of the ships, but rather thought of the newbuilding contracts as a form of speculation. When it was clear that the market was improving, as it did during the end of the 1980s, gradually the ownership consortium became convinced that they wanted the ships to be delivered to leverage their speculation.

To handle technical management of the ships Johan Reksten was contacted. He had relationships with the same shipyard since the 1970s. Johan Reksten is the son of Hilmar Reksten, who was not only a shipowner but also a Norwegian hero, who had assisted the Norwegian government from London during the Second World War. Hilmar was deemed to be the richest man on the globe in 1973- but was exposed to risk since he had all his VLCC oil tankers in the spot market, and Johan was portrayed on the front page of Time as the world's richest heir. What followed was a long period of misfortunes, where the dark side of a Norwegian national hero was unmasked. After the collapse of the Reksten empire, Johan Reksten had kept a technical management organization in Bergen, which was entrusted to manage the reefers.

During the building of the ships, the Polish Department of Industry decided to dismantle the shipyard, which was a great risk to the investor consortia. Certainly, they had bank guarantees, which would theoretically allow them to get all invested money back if the ships were not delivered. But it was unclear how much these guarantees were worth. The earlier relationships that Arnhög, Larsson, and Reksten had to the shipyard were proven to be of high value. The manager of the shipyard when STC built the product tankers had now become No.2 in the Department of Industry, and a meeting was set up with him and the Minister of Industry. After the meeting, the minister was on board, convinced that the ships should be finished.

When the ownership consortium had decided to take delivery of the ships, they needed to find a customer. At first, a deal was almost struck with Chiquita, but through a broker, Dole approached Arnhög, with a better deal. The fleet of six ships were going to handle Dole's Central American exports to Europe, and the ships were timechartered to Dole for four years with an option for another two years. All of the crew was Polish, including the top tiers. The ships worked very well in the service for Dole and the timecharter rates of over 90 cents per cbf were very favourable for the shipowner. 
After the timecharters were prolonged, the investor consortia decided to sell the ships, due to two reasons: First, the market was still strong, but deteriorating. Second, the trend of containerization grew stronger. They got an offer from the Oetker group to buy the ships, including personnel, and timecharter contracts, and the deal was sealed.

Note: a This section is based on archival material in the form of drawings, contracts, for the newbuildings, as well as interviews with key actors such as Mats Arnhög, Christian Larsson, and Per-Olof Oweson. The story about the shipping investments of Mats Arnhög are described in Lennerfors, T.T. 2016. Elling Ellingsen - The Shipping Entrepreneur, Stockholm: Medströms; b Deadweight tonnage (DWT) expresses the quantity of goods a ship can carry including provisions, lubricants, and fuel.

Bilspedition as Owner: Ship Investments and the Golden gos that Never Came

To understand Bilspedition's ownership of Cool Carrier, it is necessary to give a brief orientation about what kind of company Bilspedition was ${ }^{6}$. In the early 1980s, Bilspedition was a land logistics company, basically trucking, owned by truck-owners and Saléninvest. In 1982, Martin Lundberg became CEO of Bilspedition and embarked on an expansive strategy. Lundberg has explained that Bilspedition was quite strong in the Swedish market but weak internationally and that they had to grow in order to offer a complete transport solution, to become a full transport house. Parallel with this, and perhaps even more important, was the will of the CEO to grow and leverage the company. Since organic growth was perceived as too slow, Bilspedition started to buy other companies. Scansped, Sweden's largest group in international transport and forwarding, was purchased in 1985. Later, Bilspedition bought land logistics companies in Finland, Norway, Denmark and Poland. It also expanded offshore. Most of the shipping investments were done because of the potential profits in the segments, but some synergies were also envisioned. Bilspedition expanded into bulk carriers, but for our purpose the most important deal is when they bought Cool Carriers.

Strategic change in two dimensions followed at Cool Carriers from 1987 and onwards. First, Cool Carriers revised its fleet policy. Rather than just operating tonnage that was owned by a surrounding ecosystem of ship-owners, Cool Carriers began to invest in its own newbuildings, and second-hand tonnage. Relating to our discussion about various actors in chapter 1, Cool Carriers became

6 Lennerfors 2009, pp. 115-116. Apart from interviews with Cool Carriers, this part draws on interviews with Martin Lundberg, the manager of Bilspedition, as well as Göran Bergkvist, head of ScanShip, the shipping division at Bilspedition. 
more of a ship-owner than it once was. In corporate documents, it was explained that Cool Carriers had transferred from a cautious low-risk philosophy to higher risk strategy ${ }^{7}$. The new policy was that about $40-50 \%$ of the pool should consist of long-timecharters and owned tonnage. Cool Carriers invested 65 million USD between 1987 and $1990^{8}$ and committed to long-term timecharters, amounting to $1135 \mathrm{~m} \mathrm{SEK}$ from $1990-1995^{9}$. The feeling at the time was:

The revised policy implies an altered course towards a higher risk profile, but with substantially increased profit potentials and, above all, longterm expansion and control of the core fleet. The significance of the latter aspect can hardly be overemphasized by Cool Carriers as a dominant player in a rising market ${ }^{10}$.

In this fleet renewal, the competencies of Cool Carriers, inherited from Salén, could be used. The ship types, such as the Crystal class and the Northern reefer class, were developed by Cool Carriers. Although it was framed as an ambitious $R \& D$ programme ${ }^{11}$, many internal sources have explained that these ship types were not innovative, but rather just efficient and simple specialized reefers. In a sense, the changes made were just incrementally better than the latest ship types developed at Saléns - the Spring vessels. An idea of the magnitude of the fleet renewal is to see a snapshot of delivered or to be delivered tonnage to Cool Carriers or related owners from 1989 (See Table 2).

Second, apart from expanding the fleet, Cool Carriers was embarking on a path of vertical integration - to become an integrated provider of transport. It integrated vertically regarding the maritime business. Rather than the pool being the core business of Cool Carriers, its business areas quickly expanded for example into crewing and technical management. Also, it has been explained that the CEO, Bo Natt och Dag was strongly promoting the development of the vision of the complete Cool House (Sw. Kylhuset) that aimed at expanding the business beyond sea transport. For example, terminals were added to the business. Furthermore, attempts were made to investigate whether Bilspedition's land logistics business (Autotransit) in the Netherlands could serve as a partner to Cool Carriers in order to integrate vertically to be able to deliver refriger-

\footnotetext{
$7 \quad$ Cool Facts 1989, p. 5 .

8 Cool Facts 1990, p. 5 .

9 Report to the board of directors of Cool Carriers, p. 5. Presented in March 1988 by Peter Rothschild and Mats Ruhne. Mats Ruhne's private archive.

10 Cool Facts 1989, p. 5 .

11 Cool Facts 1989, p. 5 .
} 
White Dolphin, 1988

White Manta, 1989

Hansa Bremen, 1989

Hansa Visby, 1989

White Castle, 1989

Ivory Bay, 1989

Atlantik Frigo, 1989

Amer Himalaya, 1990

Amer Fuji, 1990

Ivory Ace, 1990

Pacifik Frigo, 1990

Ivory Cape, 1990

Blue Crest, 1990

Hansa Lübeck, 1990

Hansa Stockholm, 1991

Blue Cloud, 1991

Blue Ice, 1991

Blue Sky, 1991

Crystal Prince, 1991

Crystal Pride, 1992

Crystal Primadonna, 1992

Crystal Privilege, 1992

ated goods inland in the Netherlands. The conclusion was that there were no synergies.

According to a board member of Cool Carriers, "The feeling was that Bilspedition changed very much of Cool". But what explains this strategy of growth, financial risk-taking, and vertical integration? The first explanation is the very reason for which Bilspedition bought Cool Carriers. According to Martin Lundberg, Cool Carriers was bought in order to sell it to Lauritzen in exchange for Tor Line and DFDS's land logistic business that Lauritzen owned:

We wanted to buy Tor Line and DFDs transport and spedition business, since they had entered the market as one of our competitors. That was troublesome, since they were very competitive. 
Lundberg of course knew that Lauritzen was interested in reefers, but one should also point out that Lauritzen's reefer division was at the time ailing and under revision by the consultancy company McKinsey. Lauritzen was therefore probably not very willing to invest in the reefer segment. Another reason which complicated the deal were the European authorities. Lauritzen would become too important on the reefer market if they merged with Cool Carriers. Informal negotiations with the authorities in Brussels were held, but they were lengthy, time-consuming, and did not result in the desired outcome. A third obstacle, as so often happens in mergers and acquisitions, was that the owners of Lauritzen and Bilspedition had diverging ideas about the value of the companies that were pieces in the transaction. Eventually, the deal never materialized, but it had impact on the strategy. A software company will inevitably be less valuable than a hardware company, and Bilspedition's fleet expansion policy was partly related to a wish to make Cool Carriers a more valuable object to trade with Lauritzen.

The second reason is the very business philosophy and strategy of Bilspedition. It was a company focused on high growth and it had a high risk profile. This was partly due to the agency of Martin Lundberg but also because of the context of the stock market. Bilspedition's ambitions were fuelled by cheers from many stock market analysts and investors, since increased ownership of reefer vessels could lead to higher earnings and stock price. This owner strategy strongly affected Cool Carriers. A related reason was that many Swedish ship-owners were at this time expanding and it is likely that Bilspedition got confidence from this collective expansion. A last explanation was that the business strategy of the early years of Cool Carriers was no longer seen to be viable. Martin Lundberg explains that "We had difficulties in securing the tonnage for our operations. We had to abandon the idea that we were just pool operators". When the market gets better, some owners decide to operate the ships by themselves or timecharter them out directly to some customer. This led to a contraction of Cool Carriers' pool which had to be compensated with own tonnage. In short, while the pool strategy was beneficial in a lukewarm market, in a growing market the policy had to be changed.

\section{The Winter Ships Return to Swedish Ownership}

In 1988, three Winter ships, developed by Salén in the end of the 1970s, were bought by the Swedish shipping entrepreneur Folke Patriksson and his new business partner Lennart Bylock. It was the initiating business deal in the new partnership which soon became formalized as Bylock \& Nordsjöfrakt. Folke, in his autobiography, explained that: 
"One day Lennart called from London. There he had encountered Christer Salén, which had been told that three of Salén's old, nice reefers were up for sale for a good price. Both Lennart and I thought it was an attractive project. We took the chance and together bought three of the so-called Winter vessels, Winter Water, Winter Wave, and Winter Moon. Bylock got 60 percent, Nordsjöfrakt 40. It was our first joint deal"a.

A few years later the remaining three Winter ships were bought by the newly formed Bylock \& Nordsjöfrakt (B\&N). When the ships were bought, the company had no competence in reefers, and therefore intended to function as a ship-owner, outsourcing commercial operations. Still, the reefers did something to Bylock \& Nordsjöfrakt. Nordsjöfrakt had earlier just been in the short-sea shipping segment, and the reefers took B\&N to the next level. It became an international company.

"To begin with, almost all our ships were bunched up in the North Sea and Baltic Sea, it was really just the Winter boats that were spread out across the map's vast oceans. But it was a new world that lay before us"b.

Bilspedition owned parts of Nordsjöfrakt and B\&N employed their vessels in the Cool Carriers pool. There were even plans to merge B\&N with Cool Carriers, which would make sense from Bilspedition's perspective. Bilspedition was, as we have noted, interested in making structural deals. But nothing materialized. Furthermore, Seatrade had grown to become a new major player within the reefer industry in the 199os, and $\mathrm{B} \& \mathrm{~N}$ decided to try out this pool. But for B\&N, the reefers were not the core business.

After various offers to buy the Winter vessels from Cool Carrier's new owner Höegh and one of its former owners Mats Ruhne, in 1997, Svenska Orient Linien $\mathrm{AB}$, owned by $\mathrm{B} \& N$ underwent an IPO and the six Winter vessels were part of that IPO. The reefer market was good in 1997, so the Winter vessels were a way to make the offer more enticing. Later, the ships were sold by SOL at a low price.

Notes: a Patriksson, F. narrated for Ulla Linton, 2012. Att kunna ta en storm, Gothenburg: Breakwater, p. 149; b Patriksson, F. 2012, p. 149.

This expansion at the end of the 1980 s was experienced by many as an era of hope. People spoke about the upcoming Golden 9os, where the earnings would be over 100 cents per cubic feet. This discursive construction of the future legitimised the newbuilding programme. Initially, the strategy paid off.

However, there were critical voices. Peter Rothschild, a member of the Five was invited by Bilspedition to evaluate the business operations of Cool 
Carriers in 1987 . Mats Ruhne was involved in producing the report ${ }^{12}$. Some people within the company chose not to cooperate in this evaluation due to the history of the Five, while others did. Although Bilspedition was now the sole owner, the organization was still split and due to the turmoil people had different loyalties. The report criticized the business for having moved away from Cool Carriers' original goal, namely to be a software company. While the upper management of Cool Carriers considered the acquisition of ships a necessity, the report shows that there were dissenting views amongst those still loyal to the Five.

1990 was a really bad year for shipping. Iraq had just invaded Kuwait, and the shipping markets were affected. Bilspedition, which now had investments in reefers, forest product carriers, and oil-bulk-ore vessels, worsened every year. In 1992, the share-price was down to 20 SEK against a peak of 160 SEK at the end of 1989. Because of this unfortunate development, Martin Lundberg was replaced by the new CEO Håkan Larsson and Bilspedition started to sell off their maritime businesses, for example Cool Carriers. This downturn affected the strategy of Cool Carriers. After having engaged in negotiations with different potential buyers, for example NYK and French Altus, in 1994 Cool Carriers was sold to the Avrista consortium, consisting of Höegh, holding $75 \%$ and Tufton Oceanic, holding $25 \%$. The following year, Bilspedition was bought up by the German logistics company Stinnes and the company was renamed Schenker-втL.

To sum up, under the ownership of Bilspedition, Cool Carriers changed strategy, which paid off until the shipping markets started to fall in the early 1990s. The owners, affected by the bad results in the shipping segments, needed to divest. From the perspective of employees at Cool Carriers, Bilspedition was not a particularly competent owner. Although they had recruited an experienced manager for all of their shipping investments, neither he nor the CEO of Cool Carriers had any specialized knowledge of the reefer industry. This resulted in a lack of a business idea for Cool Carriers, when it became clear that it was difficult to attract tonnage to the Leonina pool. We can only speculate what would have happened if the Five would have remained at the helm of Cool Carriers. At least from their perspective, Cool would have developed differently. Since they all were highly competent and had been running SRS, it is likely that their departure negatively affected the business development of Cool Carriers. At the same time, it might have been impossible for them to run Cool Carriers due to their negative reputation within the company. Particularly 
when the market turned down in the early 199os coupled with the problems that Bilspedition underwent, people at Cool Carriers were frustrated. Some key employees decided to leave the organization to work with a growing competitor, Seatrade.

\section{Höegh and the Others: Broadened Market Presence with Limited} Investments

It is time to get acquainted with the new owner of Cool Carriers. Höegh started out in 1927 as a company owning oil tankers, and later expanded into liner shipping (Java Pacific Line and West Africa Line) ${ }^{13}$. In the 1960s the company diversified into oil-bulk-ore carriers and car carriers. The latter business was developed in a joint venture with the Norwegian ship-owner Ugland in 1970 creating HUAL (Höegh Ugland Auto Liners). In 1973, Höegh contracted the world's first LNG carrier with special tanks and started to develop this business segment. In 1987, Höegh underwent an IPO, which was the trend for many shipping companies in the late 1980s. As a consequence of the Exxon Valdez oil-spill and the resulting Oil Pollution Act, which posed greater financial risk for companies engaged in oil transport, Höegh's ово and tanker related activities were demerged and listed. The Höegh group had been through 12 years of consolidations but it was time to expand. In the context of the history of Höegh as a diversified shipping company, a fair interpretation for why Höegh bought Cool Carriers is because Höegh was interested in further diversification. The diversification would not end until 2000, when Höegh placed all its focus on car carriers and LNG.

In other words, it was not an interest in reefers per se, but rather a will to continue exploring different shipping markets, hedging the cyclical nature of various shipping markets against others, that was Höegh's interest for buying Cool Carriers. Höegh, the chairman of Höegh, stated that Cool Carriers was bought due to its strong market position, and that although the reefer market is weak at present, the deal could pay off in the future ${ }^{14}$. As we know, the future is always unknown, and a weak market can be the perfect time to enter a new business segment. Also, reefer shipping was at the time seen as low risk, industrial shipping, and Höegh's decision was not discussed to a large extent in the Norwegian shipping community. Apart from Höegh's own interest in diversifying, a main driving force behind the deal to acquire Cool Carriers is said to have

13 Bakka, D. Jr. 1997. Höegh: shipping through cycles 1927-1997, Oslo: Leif Höegh \& Co Asa.

14 "Leif Hoegh is looking for more cool deals". TradeWinds 28 January 1994, p. 19. 
been Ted Kalborg of Tufton Oceanic - an investment banker - and the holder of $25 \%$ of the shares of Avrista. Soon, however, Höegh bought Tufton's share in Cool Carriers.

Mats Jansson, who had extensive experience leading shipping companies within dry cargo and oil tanker, was appointed CEO of Cool Carriers in May 1994. The strategy of Cool Carriers, when Jansson entered the company was to reduce market risk and get rid of timechartered tonnage. As we know, vessels were timechartered from 1990 to 1995, and given the downturn of the market, the charter price naturally surpassed current market rates.

The result was negative in the first year of operation, 1994, due to the depressed market and the loss-driving timecharter agreements. As a part of the deal, Bilspedition paid the losses during 1994, but then the results turned black. Due to the positive expectations in 1995 and 1996, Höegh expanded its ownership of vessels. Höegh was, as an owner interested in expanding in the segment, particularly through the acquisition of second-hand tonnage ${ }^{15}$. While they had no specific knowledge about the reefer market, they were willing to invest, and to a large extent trusted the local organization with its leader Mats Jansson. Since Höegh was based in Oslo, there were some discussions about moving Cool Carriers to Norway. But, due to the risk of losing know-how - not all were willing to move to Norway, the organization stayed in Stockholm.

By the end of 1995, Höegh therefore invested in reefer vessels connected to Cool. From the annual report, it is stated that the company's total assets had increased from NOK 3,964 million at the end of 1993 to NOK 5,568 by year-end 1995 , a result that is partly attributable to reefers ${ }^{16}$.

Cool Carriers did well during 1995 and 1996, but Mats Jansson had an idea that the company required a greater market presence and a larger fleet in order to reach economies of scale. The management's plan was to collaborate with other players within the industry. A potential partner was the South African liner company Safmarine, which had been founded in 1946. Following the end of the sanctions against South Africa, Safmarine began to look for new opportunities in the international market. Apart from its liner services with container ships, it expanded into the reefer segment and had a fleet of ships as well as a commercial operation. The idea from Cool Carriers' perspective was to take over both the ships and the human resources of Safmarine. The hardware would provide a welcome boost to Cool Carriers' fleet, while the software, called Universal Reefers, included good relationships to the South African fruit exporters Unifruco and Outspan. These exporters were not only partners to

15 "Leif Hoegh is looking for more cool deals". TradeWinds 28 January 1994, p. 18.

16 Leif Höegh Annual Report 1995. 
TABLE 3 Revenues, operating profit, book value of vessels and investment in vessels for Höegh's share of Cool Carriers 1994-2000. In 1997, figures correspond to Höegh's $50 \%$ share of Cool Carriers after the merger with Safmarine

\begin{tabular}{lccccccc}
\hline Year (NOK million) & 1994 & 1995 & 1996 & 1997 & 1998 & 1999 & 2000 \\
\hline Freight revenues & 711 & 744 & 1074 & 752 & $\begin{array}{l}787(107 \\
\text { MUSD })\end{array}$ & 96 MUSD & 174 MUSD \\
Operating profit & -61 & 6 & 4 & 122 & $\begin{array}{l}44(-8 \\
\text { MUSD })\end{array}$ & -9 MUSD & 4 MUSD \\
Book value (vessels) & 174 & 672 & 1291 & 976 & $\begin{array}{l}829(116 \\
\text { MUSD })\end{array}$ & 154 MUSD $) ~ 137$ MUSD \\
$\begin{array}{l}\text { Investments in } \\
\text { vessels }\end{array}$ & 213 & 566 & 722 & 0 & 0 & 0 & 21 MUSD \\
\end{tabular}

a Leif Höegh Annual Report 1997, p. 57, Leif Höegh Annual Report 1998, p. 45, Leif Höegh Annual Report 1999, p. 44.

Universal Reefers but also owned $50 \%$ of it. The fruit exporters, mostly Outspan, wanted to remain in control of the software side and urged Safmarine to keep its 50\% stake. A South African shipping company was a more preferred partner. However, in September 1997, Safmarine pulled out of its ownership in Universal Reefers to avoid a conflict of interest between Cool Carriers and Universal. Universal Reefers would be run by the fruit exporters Unifruco and Out$\operatorname{span}^{17}$.

Höegh and Safmarine joined forces on the 1st of January 1997 and formed the new company Unicool. It consisted of the Cool Carriers software company and 18 ships owned by Höegh and Safmarine and its assets were valued at over 400 MUSD. The ownership structure of the new company was Safmarine International (50\%), Höegh (49.8\%) and Mats Jansson's company Girestad. The company in Stockholm was now both a significant ship-owner and an operator (see Table 4). The organization, the software, was intact, but Safmarine had exchanged the ownership of their vessels for the ownership in Unicool. When discussing the deal with Mats Jansson, he says that the philosophy was to expand, to get a larger market share without a significantly higher risk. Safmarine's fleet also suited Cool Carriers well.

Another aspect of the expansive but still low-risk strategy was to try to collaborate with companies in new pools. Cool Carriers had a relatively small

17 "Safmarine pulls out of charter". South China Morning Post, 17 September 1997, <http:// www.scmp.com/article/211636/safmarine-pulls-out-charter>. 
Spring Bride

Spring Dream

Summer Breeze

Summer Flower

Summer Meadow

Summer Wind

Crystal Prince

Crystal Pride

Crystal Primadonna

Crystal Privilege

Ivory Dawn

Arctic Universal

Baltic Universal

Lincoln Universal

Tasman Universal

Caribbean Universal

Coral Universal

Erikson Crystal

presence in the handy sized reefer segment. A representative of Cool Carriers said that "for two years [i.e. since 1994] Cool has been searching for a partner, realizing it was too small of a player on its own"18.

The partner was a relative newcomer on the reefer scene - Eastwind - with its base in the Us. With a fleet of about 25 handy sized reefers, the new reefer venture ECo Shipping was a fact. The $\mathrm{E}$ in the name came from Eastwind, and the Co from Cool Carriers. The start of the operations was the same date that Safmarine and Höegh joined forces, 1 January 1997. The company was co-managed from Stockholm and from Eastwind's offices in New York. Glenn Selling was head of the Swedish division, while Toby Moors was head of the American. In TradeWinds, more about the respective strengths is understood:

In Eastwind's case this was ten-years' experience of operating small reefers. For Cool Carriers it was a history of building long-term relationships with customers. ${ }^{19}$

18 "Eastwind and Cool to share management". TradeWinds 15 November 1996, p. 12.

19 "Reefer venture on a rough ride" TradeWinds 23 December 1998, p. 11. 
ECo was strong on fish, kiwi from NZ to Japan, mandarines from Morocco to Russia $^{20}$. But in the long run, ECo Shipping was not sustainable. The smaller ships did not have significant earnings due to the heavy competition from the container lines. Rather, Cool Carriers had to focus on larger ships to achieve economies of scale. In 1998, the management of the pool from Stockholm was discontinued, and all commercial management of the ships was taken care of in New York. Eastwind president John Kousi explained: "Rather than us both focusing on each size it made sense for Cool to concentrate on the larger ships and us to focus on the small ships. It means that together we now cover a broad spectrum and that we can offer customers a complete range of sizes"21. In 1999, Eastwind expanded the Eco shipping pool with outside owners ${ }^{22}$.

Cool Carriers delivered a better result in 1997 and the annual report notes that, "high contract coverage and better contribution from cars on traditional ballast legs, in good cooperation with Höegh Ugland Auto Liners, contributed to the improved result" ${ }^{23}$. So, although the business of Höegh and Cool Carriers seemingly had not much in common, some synergies could be created between the car carrying division and the reefer division of Höegh.

Business kept expanding, and Cool Carriers managed to win a contract with Noboa in September 1997, that led to the possibility of an integrated service minimizing ballast voyages. In the Höegh annual report of 1997, the circular trade that according to Cool Carriers was a subjective point of pride was detailed:

Due to its size and customer base, Cool Carriers can offer competitive logistic solutions. One example is the long term agreement entered into with the Noboa group in September for the transportation of bananas from Ecuador to the us west coast and Japan. The transportation of bananas is combined with Cool Carrier's present agreement with Sunkist for the transportation of citrus fruits from the USA to Japan. Backhaul cargoes from Japan includes secondhand cars to South America and New Zealand and from New Zealand apples and kiwi fruit are loaded for Europe. This is a good example of a system which through a combination of cargoes optimizes the utilization of the vessels, creating a more cost efficient solution for the customers ${ }^{24}$.

\footnotetext{
$20 \quad$ Svensk Sjöfarts Tidning 1996/47, p. 6. Interview Glenn Selling.

21 "Reefer venture on a rough ride" TradeWinds 23 December 1998, p. 11.

22 "Rates prompt reefer players to opt for spot" TradeWinds 18 February 2000.

23 Leif Höegh Annual Report 1997, p. 54

24 Leif Höegh Annual Report 1997, p. 54
} 
Furthermore, a new pool was set up, which was similar to the setup of ECo Shipping. The reason was that "increased competition from the container lines - and customer demands for fixed arrivals, reefer containers, and special quality requirements - has locked much of the more sophisticated reefer tonnage into fairly rigid trading systems. This change in the main market has left a large fleet of less sophisticated, standard pallet-reefer vessels of good quality outside the systems. However, these vessels still offer competitive advantages and flexibility to many customers, owing to cost advantages". It was further explained that:

The company will focus on traditional reefer shipping but will also engage in emerging markets with future potential, and specialise in the somewhat shorter market perspective allowing it to take advantage of opportunities arising from short to medium term market fluctuations ${ }^{25}$.

On 1 January 1999, Arctic Reefers was set up with tonnage from Ahrenkiel of Hamburg, Eastwind of New York, Mediteranska Plovidba of Korcula, the Dawn group of London, Tokumaru Kaiun of Tokyo, Zodiac of London and Osterreichischer Lloyd of Vienna.

Also, the creation of Arctic Reefers was a result of the Cool Way - a new strategy announced in 1998. They thought of this as the Toyota Way of reefer shipping, with a base in skilled and competent staff, customized services, enhanced operative efficiency, and cutting-edge technology. This is also a discursive strategy to position oneself as a well-organized and modern company. For example, a new liner service to South Africa offered door-to-door services when the export market was deregulated in 1999. The Cool Way was seen as the core of Cool Carriers, and the creation of Arctic Reefers was also a way to distance Cool Carriers from its less sophisticated, but still potentially profitable, tonnage.

On the tonnage side of the business, two newbuildings were made. In 1996, Mediteranska Plovidba, or Medplov, of Croatia ordered two 600 ooo cbf reefer vessels at Split Shipyard, with a scheduled delivery for the end of 1998 and early 1999, for an estimated 30 mUSD each. Mediteranska Plovidba, a state-owned shipping company, had close relationships with the Split shipyard and it is plausible that ships were ordered to secure employment at the shipyard. Since the early 1980s Medplov had ordered seven reefer ships at Split, many of which have been operated by Cool Carriers ${ }^{26}$. Höegh took an ownership share in the

$25 \quad$ Leif Höegh Annual Report 1998.

26 "Split clinches double-reefer order" TradeWinds 29 November 1996, p. 5. 
two ships, of $20 \%$ each. The first one was delivered in January $2000^{27}$. According to Cool Carriers, these ships were probably the last ones needed of today's reefer design. However, the staff at Cool Carriers were working on the next generation of reefer vessels, called the Pallcon vessels, in which loading and unloading of the fruit pallets would take place utilizing elevators through side doors in the hull. Also, a high container capacity was a main part of the design.

Turning to ownership, according to the upper management, the relationship between Safmarine and Höegh went remarkably well. This dual ownership also led to more independence and agency for the Cool Carriers organization to develop its own strategy. Of course, the strategy had to benefit the owners, but both owners adopted a hands-off policy and let the competent staff led by Mats Jansson run the show. But it seemed that Cool Carriers was destined to be plagued by ownership problems.

The owner of Safmarine, the insurance company Old Mutual, was going to do an IPO in 1999 and wanted to sell their shipping interests before the IPO. Maersk bought the liner business of Safmarine ${ }^{28}$, and the bulk and reefer divisions were sold to Capital Finance (owned by the Greek family Restis) for R210 million, or about $35 \mathrm{~m} \mathrm{USD}{ }^{29}$. Restis and their related company Enterprise Shipping and Trading was established in 1973 and consisted at that time of one reefer ship. In 1995, they had built up a managed fleet of 26 reefers. But the main objective for Restis when buying Safmarine, was not its reefers, but its bulkers ${ }^{30}$. When Restis bought Safmarine's share of Unicool, Guttormsen from Höegh stated:

We are very happy about this and know Restis already, as the company has had vessels in the Cool Carriers pool before. It is a long term player in this market and that is also positive ${ }^{31}$.

TradeWinds reported that Höegh had not been consulted before Safmarine sold its stake to Restis. And behind the happy facade, there was a concern that Restis was not a suitable owner for Cool.

The collaboration between Restis and Höegh was far from harmonious. We have stated that Höegh ran Cool Carriers as a stand-alone operation, while

27 "Hoegh takes stakes in two reefers" TradeWinds 8 April 2000.

28 Jephson, C. and Morgen, H. 2014. Creating Global Opportunities, Maersk Line in Containerisation 1973-2013, Cambridge: Cambridge University Press, p. 263.

29 "South Africa: Safmarine Falls Into Foreign Hands". AllAfrica 8 April 1999, <http://allafri ca.com/stories/199904080036.html>.

$30 \quad$ "Restis gains a stake in reefers" TradeWinds 9 April 1999.

$31 \quad$ "Restis gains a stake in reefers" TradeWinds 9 April 1999. 
Restis had a much more hands-on approach. From the perspective of the former's locus of agency, Cool Carriers' upper management, there were a range of issues that hindered a harmonious collaboration. At first, Restis wanted to integrate his own reefers into the Cool Carriers operation, old reefers that did not fit into the high-quality profile of Cool Carriers ${ }^{32}$. This was met with scepticism from Cool Carriers since it diluted the brand and complicated the operations. Also, compared to Safmarine and Höegh, Restis was not interested in developing Unicool and continuing the expansion, but wanted to commit their funds to other segments, such as bulk. Restis also questioned why Cool Carriers had so much cash. Cool Carriers' personnel speculated that Restis was probably more interested in the hardware part of Unicool rather than in the software. Cool Carriers, the former locus of agency, had now a rival who saw the software as an obstacle rather than a resource. We know, however, that Cool Carriers has always been an independent organization willing to oppose owners that they did not like. And this is exactly what happened - there was resistance. If Restis would have owned $100 \%$ of the company, such resistance would have been futile, but it is likely that Cool Carriers, together with Höegh, collaborated to reach a solution.

It was decided that to solve the deadlock, which hampered business development, one party had to buy out the other. There was a so-called Texas Close Up, where you placed a bid for either selling or buying the ships. If your bid was 100 it meant that you either had to buy the vessels for 100 or sell the vessels for 100. The highest bidder wins. Restis won the Texas Close Up, but after some turbulence, Höegh became $100 \%$ owner of Cool Carriers from the beginning of 2000.

Höegh had been an appreciated owner, but as the 200os were approaching, Höegh believed that the reefer segment did not have a viable future. Furthermore, the financial resources tied up in the reefer business could be better used in the car carrying and LNG segments. Höegh was looking for an exit.

This exit affected the business development of Cool Carriers. In fact, there was a newbuilding program underway at Cool Carriers with the Israeli company Agrexco (Agricultural Export Company), a leading exporter of Israel's fruit. Agrexco were using two ships for their exports, but both of them were built in the early 1970s and needed replacement, not the least due to their low container capacity ${ }^{33}$. The two newbuildings that Cool Carriers were developing were far from ordinary. They had pallet friendly reefer holds, and tween-

32 "Cool couple splits up" TradeWinds 26 November 1999.

33 The container capacity was 80 TEU. "New Reefer up Agrexco fruit trade" TradeWinds 24 October 2003, p. 16. 
decks with side doors. Also, they had a box capacity of 880 TEU. They were described as "part reefer, part container and part roll-on, roll-off and have side loaders"34. In other words, completely customized ships for a particular company's transport needs. But due to the exit of Höegh, the owner was far from willing to commit to take part-ownership in the vessels. The negotiations were stalled to great frustration for Cool Carriers staff, and eventually the ships were ordered by another owner. Delivered in 2003, they turned out to be very bunker inefficient and heavy ships. This did not matter that much since they were tailormade for Agrexco, but when Agrexco went into bankruptcy in 2011, the upper management of Cool Carriers were relieved that they did not carry out the project.

Höegh was looking to exit and Lauritzen turned out to be the buyer. We will describe this deal more in the part on Lauritzen's history. Höegh exited the software part in 2001, but retained ownership in the vessels, since Lauritzen was only interested in the software and not in the hardware. From 2000, Höegh dismantled its reefer fleet, and finalized their exit by 2003 (See Table 5).

TABLE 5 Höegh's exit from the reefer segment

\begin{tabular}{lllll}
\hline Year $^{\mathrm{a}}$ & 2000 & 2001 & 2002 & 2003 \\
\hline Reefers & 17 & 14 & 12 & 0 \\
\hline
\end{tabular}

a Höegh Annual Report 2000, 2001, 2002, 2003.

\section{Summary}

Cool Carriers started out as a continuation of the reefer division that existed at Saléns. Given the foresight and risk awareness of the upper management of the reefer division, Cool Carriers could be set up immediately after the bankruptcy. Much of the identity of the former organization was carried on to Cool Carriers. In the post-bankruptcy disorder, it was not entirely clear how everything was organized regarding ownership of both the organization and the related ships and this led to shattered expectations, broken promises, and harsh conflicts between the organization and the upper management of Cool Carriers

34 "Breakbulk carrier Seatrade orders container ships". Journal of Commerce, 2 August 2014, $<$ http://www.joc.com/maritime-news/container-lines/breakbulk-carrier-seatrade-or ders-container-ships_20140802.html>. 
- the Five - as well as within the owner consortium. Given the antagonism between the rest of Cool Carriers and the upper management and owners, the organization developed a subjective sense of autonomy which is complemented with a discourse that they are in control - that "they have to look for other owners" if the present owners do not suit their taste. This new subjective dimension was an addition to Salén Reefer's subjective feeling of market-leading knowledge, operational excellence and working with high-class customers which also continued to reign at Cool Carriers. During the late 1980s the market prospects looked good and people discursively described the 1990s as being "golden". However, the 1990s never fully lived up to these expectations. Throughout that decade, Cool Carriers had different owners but still they perceived themselves to be in charge, and also resisted when the owners acted too much against their interests. This subjective feeling of pride and autonomy thus significantly affected the business of Cool Carriers. The main organization - Cool Carriers - was discursively positioned as modern and high-class with large reefers, even though they also owned second-tier brands such as ECo and Arctic, which were separated from the main organization, but still linked to it. Now, in 2001, Cool Carriers had been acquired by Lauritzen, and when you read the story about Lauritzen from the mid-1980s onwards to the acquisition, please note the interesting similarities and differences that existed, in terms of fleet renewal and profitability, discursive positioning, and subjective feelings. 


\section{J. Lauritzen}

In 1884, the consul Ditlev Lauritzen (1859-1935) moved from his hometown Ribe in Western Denmark to Esbjerg to start the company J. Lauritzen'. The company was named after Ditlev's father since Ditlev was under 25 years old and not of age to start a business. He started an import business with wood, coal and fodder. He began with chartered ships for his imports but bought a few ships in late 188 os and could call himself a ship-owner. In 1895 , the newly started shipowning company Vesterhavet, had a fleet of three ships. The fleet grew remarkably, and merely five years later, another seven ships had been added to the fleet. Lauritzen was both a shipowner and a shipbroker until 1918 when he closed down his shipbroking office. Apart from shipping, many of Lauritzen's businesses were onshore. The Ditlev Lauritzen as portrayed by researcher Ole Lange is a truly dynamic entrepreneur, constantly on the move, catching new opportunities wherever they would arise. But it was the shipping business that was the core, and more precisely the transportation of coal, wood and cotton. By the end of 1914, the fleet comprised 26 ships. At about that time, the headquarters moved to Copenhagen. Sometimes Lauritzen's ships carried fruit as a backhaul cargo - the first shipment of oranges was from the Spanish Mediterranean coast to England in a conventional general cargo vessel in 1905.

\section{Mediterranean Adventures}

The time during the First World War was, not surprisingly, turbulent. For Lauritzen, the increasing demand for ships during the war served as an impetus to sell off the current fleet and order new ships. This was in line with his vision to have a fully controlled shipping company of about 50 modern ships. The strategy was successful and after the war, the fleet was sold, and what was left was a number of competent employees and 16 ships on order at German shipyards. After the war, Lauritzen continued ordering ships to profit from the post-war

1 The section on Lauritzen is based on Lange, O. 1995. Logbog for Lauritzen, Copenhagen: Handelshøjskolens forlag., Thorsøe, S. 1984, J. Lauritzen 1884-1984, Gravesend: World Ship Society., Tolerton 2008. Lauritzens corporate website <http://www.j-lauritzen.com>, the corporate magazine Lauritzen News, and interviews with former executives and employees at Lauritzen reefer division or LPR. 
boom. In the summer of 1919, he had 28 ships on order. But, since many other ship-owners also ordered ships en masse, the rates decreased in 1920. Some ships were cancelled, but in 1924 the fleet comprised 28 almost new ships. Also, Lauritzen ventured into buying the Køge shipyard, a venture that turned into a failure due to the post-war slump and lack of competence in managing a shipyard.

The market downturn affected the tramp market first, where Lauritzen was most active. It was no longer profitable to be in tramp shipping, so Lauritzen needed to rethink the business strategy. The changes were made in two dimensions. First, Lauritzen sought new, less turbulent markets, and therefore he expanded his business in the Mediterranean, rather than mainly sailing in the Baltic and the North. Also, he sought to reduce his exposure to market fluctuations by entering into more long-term contracts. Rather than being an independent player, Lauritzen entered into collaborations with other shipping companies, for example with Swedish Lloyd, but sometimes, however, he also played the role of an aggressive upstart.

In the Mediterranean, there were often opportunities to carry fruit back to Northern Europe. In 1923, of about 70 voyages to the Mediterranean, on 39 return voyages, fruit was carried from Spain in ventilated fruit carriers. In 1925, Lauritzen opened its first foreign office in Valencia, which would directly cater to the fruit trades. In September-October, grapes and apricots were transported, in November-January, oranges and bananas.

During the winter of 1926, Ditlev's son Ivar Lauritzen - who by the way was married to Lillian Kirkebye, daughter of the Fyffes banana importer A.W. Kirkebye, went to Spain and France to negotiate freight rates and conditions for fruit transport. He was just 26 years old. He, and his brother Knud, would represent Lauritzen's strategic shift into the reefer segment. This was an important event in Lauritzen's history, because from that time, fruit transport was to become one of Lauritzen's two main activities (the other one being wood and pulp from Finland). The contracts negotiated by Ivar were one-year long and Lauritzen's strategy of being less dependent on the spot market was being implemented. For both reefer and dry cargo, Lauritzen had to charter in six ships in 1926 and eight ships in 1927.

In 1927, it was time for Lauritzen to create its own liner service. Given that Lauritzen was an established player in the Mediterranean fruit market, the company was approached by a consortium of Sicilian fruit growers. They were not happy with the fact that the conference Associate Liners serving the Sicilian fruit export had increased their freight rates by $25 \%$. Lauritzen established a line with scheduled departures from Sicily to Liverpool using eight to ten steamers. The conference strongly retaliated with lowered rates. Lauritzen did 
not give in but continued competing, with the hope that they would be asked to join the conference. This did not happen, but the line continued carrying oranges and citrus from Sicily, later expanded to the north of Italy, to the UK until 1935 when sanctions against Italy made Lauritzen discontinue the line.

\section{Worldwide Growth}

In February 1932, Lauritzen was contacted by French fruit interests. The company that was going to transport their bananas from West Africa to France had suddenly turned down the business, and another solution needed to be found. Lauritzen had experience with fruit transport, but only had ventilated fruit carriers, which were not regularly used for long-distance banana transports. However, due to the urgency of the situation, Lauritzen got the contract and successfully transported the bananas from Conakry in French West Africa to Nantes in the ships Grete and Ulla. Each ship made a profit of 20000 D KK. After this success, Lauritzen offered to take care of the transport for Companie Générale Transatlantique, which catered for the West Indies, and Agences Maritimes Henry Lesage, carrying bananas from West Africa. Six ships were converted to reefers: Grete, Ulla, Erna, Else, Betty and Edith. They all had a refrigerated hold capacity of about 100 ooo cbf and a speed of 11-12 knots. Lauritzen also joined a conference with Swedish Lloyd and DFDS transporting Jaffa fruit from Palestine and established a line from Sicily to Gdynia in Poland. Also, a line was established from Canary Islands via North Africa to Antwerp based on bananas and general cargo. The banana traffic was lucrative, generating a surplus in 1932 of $634000 \mathrm{DKK}$, more than half of the total surplus of Lauritzen's shipping business. It was therefore not remarkable that Lauritzen continued pursuing this segment.

The first newbuilding that was tailormade for refrigerated cargo was Helga, built in 1932. It had refrigeration equipment from Atlas, and Atlas would be a strong partner for Lauritzen's technological development. Her maiden voyage was to Chile to pick up a load of apples for Oslo.

After the start in the Mediterranean, in 1933, Ditlev's younger son Knud Lauritzen went to New York to negotiate with South American exporters, the result of which was a number of contracts, from Chile and Equador to the U.S., Brazil, and Europe. The results from reefer shipping were good in the mid 1930 s but the outlook was considered to be insecure due to increasing competition.

Eight new reefers, Stella, Ninna, Laura, Jonna, Jutta, Paula, Asta, and Dora were delivered in 1933 and 1934 from Danish shipyards with state guaranteed loans. In this period of depression, it was a win-win deal. Helga and Ninna were 


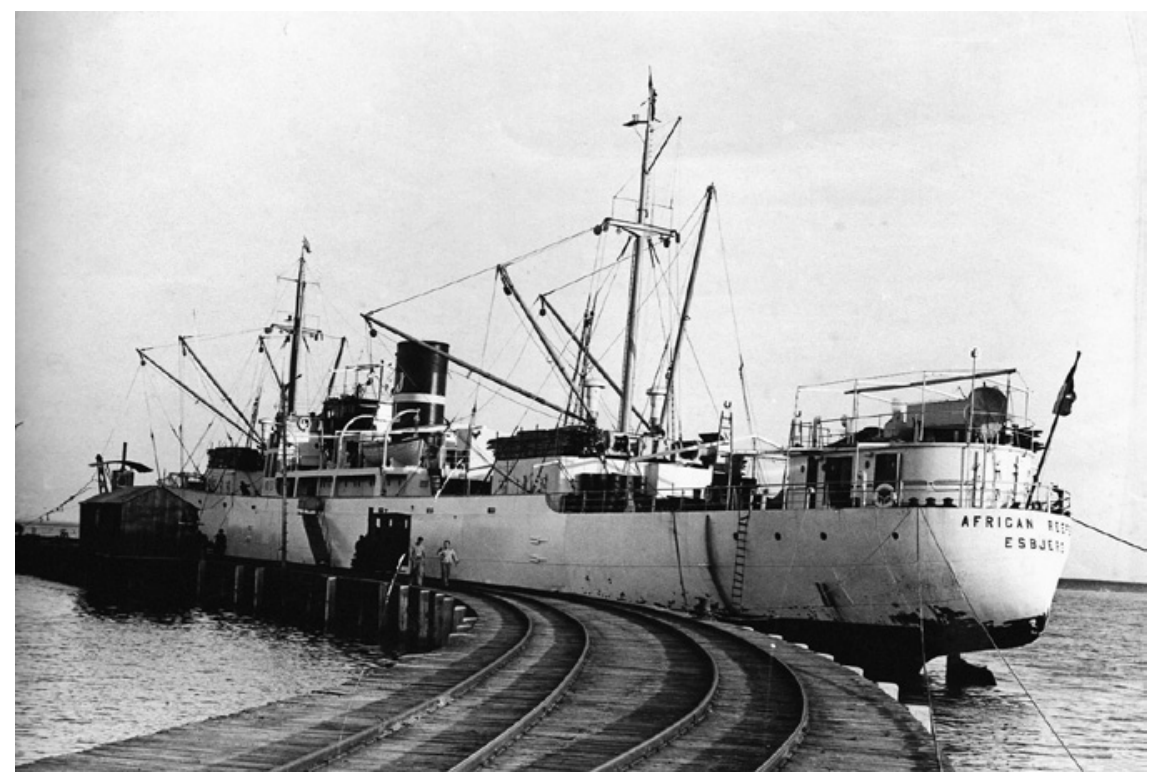

FIGURE 9 Lauritzen was the first independent reefer operator to establish itself in the global fruit trade. Pictured is the African Reefer in Puerto Cuatreros, Argentina in 1939 PHOTO: UNKNOWN

sold in 1934 at a good profit. Six ships were ordered in the summer of 1935, of which three were reefers. A few months later, Asta and Dora were sold to French fruit related companies due to flag discrimination that hindered Lauritzen from participating in the French fruit traffic. The reason for all the newbuildings was that Lauritzen believed in the future of the shipping market. He stated that he wanted to sell 30 of his ships and buy 30 new ships, because you can't stay "in the same, old clogs", a discursive sign of a subjective belief in a modern fleet. As the fruit business was developing, a series of diesel powered ships were built.

In September 1935, African Reefer, the company's first refrigerated motorship, with specialized cooling machinery was delivered, followed by five more reefers in 1936- $7^{2}$. They sailed all over the world, carrying apples, pears and oranges from Argentina, Chile, and Brazil to Northern Europe, bananas from West Africa, apples and pears from the west coast of North America to the

2 All built at Nakskov Shipyard: Canadian Reefer (1936), Brazilian Reefer (1936), Chilean Reefer (1936), followed by the slightly larger American Reefer (1936) and Australian Reefer (1937). These ships had a cargo capacity of $185000 \mathrm{cbf}$ and boasted a speed of 15.5 knots. 
Mediterranean, and bananas from Central America to San Francisco and Seattle.

Also Egyptian Reefer was bought from Maersk in 1937 - Maersk dabbled in the reefer segment but did not commit to it (see chapter 10 about Maersk). Unlike the other reefers at Lauritzen, this reefer had its engine placed in the aft. When the new reefers were delivered, all previously converted reefers went back to their former non-refrigerated trades. Indian Reefer and Argentinian Reefer were delivered from 1939 to 1941.

During the 1930s about fifteen ships were built, around half of them reefers and by 1937 the fleet boasted 47 ships. Lauritzen was the biggest Danish player transporting refrigerated goods, although both Torm and Maersk were also engaged in the fruit trade to a lesser degree. Lauritzen went into the shipyard business, buying Aalborg Shipyard. In the late 1930s, the overseas fruit and cargo business was the most important part of Lauritzen.

During the war, several of Lauritzen's reefers were sunk, and after the war only four reefers were left: African Reefer, Egyptian Reefer, Indian Reefer, and Argentinian Reefer.

\section{Rebuilding the Fleet after the Second World War}

Following the pre-war development, the liner trades were the most important for Lauritzen, especially the reefer trades. As soon as the fruit trade to the US and Europe restarted after the war, Lauritzen developed its fleet.

In 1953, the company ordered new reefer ships: Mexican Reefer, Brazilian Reefer and Peruvian Reefer ${ }^{3}$. These ships were seen as the most modern afloat. The ships incorporated innovations such as glass wool insulation, and aluminium lining instead of wood. Brazilian Reefer was christened with orange juice instead of champagne. The ships carried banana bunches to the us and Europe.

In 1957-1958, three new reefers were ordered:Arabian Reefer, Belgian Reefer and Chilean Reefer ${ }^{4}$. Rather than being painted white, the ships were red, because of easier maintenance and also to be more visible in conditions of mist. The red colour became a symbol of Lauritzen. The ships were put into contract traffic from Ecuador to Antwerp with a departure every eighth day. The older ships were put into other fruit trades and also a new service with frozen meat from New Zealand to Japan was inaugurated in 1957. In 1962, Ecuadorian Reefer

3 The speed was 18 knots and the cargo capacity $225000 \mathrm{cbf}$.

4 They had a speed of 18.5 knots and a refrigerated hold capacity of $242000 \mathrm{cbf}$. 


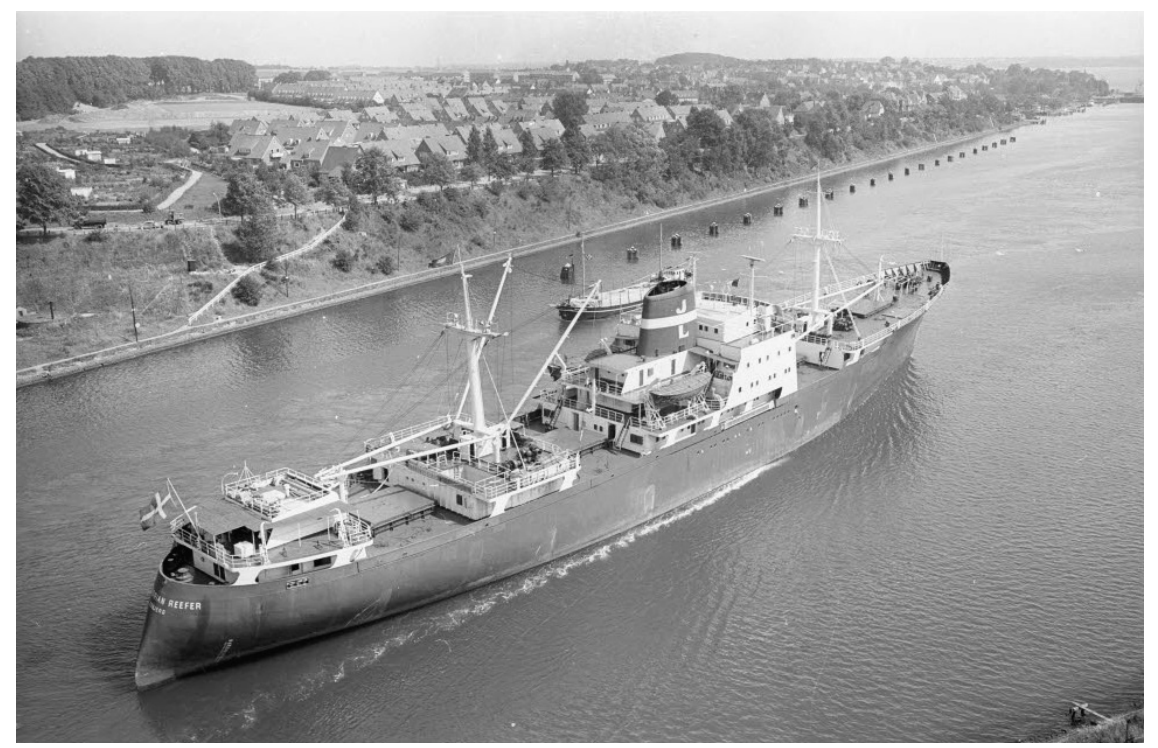

FIGURE 10 Ecuadorian Reefer sailing through the Kiel Canal in 1964 PHOTO: MAGNUSSEN, FRIEDRICH / STADTARCHIV KIEL

was delivered, which was incrementally larger and faster. Some older ships were sold in the 1960 s to keep the fleet modern.

From 1968 to 1974, these ships were followed by the Italian Reefer series ${ }^{5}$, six ships with a cargo carrying capacity of $422000 \mathrm{cbf}$, that moved at 22.5 knots. These ships had deck heights which suited pallets, about 2.30-2.40 meters. They also had aluminium gratings, which replaced the earlier wooden gratings. In short, the Italian Reefer series was designed for high speeds and palletised cargo, similar to the Salén Snow class. According to representatives of Lauritzen reefers, the Italian Reefer series was a breakthrough from earlier ship series ordered by Lauritzen.

Moving to the corporate level, we can see that although the reefer part of Lauritzen was growing, Lauritzen was losing market share in general cargo and these lines were discontinued. To continue growing, Lauritzen diversified into various shipping segments and increased its industrial interests. Lauritzen moved into tankers and shipping to the polar regions in the early 1950s. The industrial division also expanded, with Atlas in the lead, providing refrigeration equipment to many different sectors. After having bought shares gradually for about 20 years in DFDS, a company which had domestic and international

5 Italian Reefer, Nippon Reefer, Persian Reefer, Roman Reefer, Samoan Reefer and Tunisian Reefer. 
lines as well as three shipyards, Lauritzen managed to take control of the shipping company in mid-196os. The adventurous polar traffic diminished, while the oil tankers rendered good results. As a general assessment, the 1950s and 1960 s were very good for Lauritzen, particularly from the end of the 1950s and onwards.

\section{Lauritzen Peninsular Reefers 1970-1983: the Shark's Teeth}

Around 1970, Lauritzen adopted a pool concept in the reefer segment, "in order to secure economies of scale through the control of a large number of vessels from other owners" 6 . Here the histories of the British liner company $\mathrm{P} \& \mathrm{O}$ and Lauritzen were to intertwine. $\mathrm{P} \& \mathrm{O}$ had for decades been transporting reefer cargo in their liner vessels but had also invested in specialized reefers. But at the time, $\mathrm{P} \& \mathrm{O}$ had no experience in the tramp reefer segment and was looking around for a partner. They went to the market leader Salén Reefer Services, who offered $\mathrm{P} \& \mathrm{O}$ to put their ships in the Salén pool. $\mathrm{P} \& \mathrm{O}$ wanted more, but this was about all that Salén were prepared to offer, they were the market leader, and not seldom perceived to have some of the arrogance that can follow from holding such a position. $\mathrm{P} \& \mathrm{O}$ turned to the second largest company in the reefer segment - Lauritzen - and got a better deal.

What was negotiated was a joint venture - each of the partners, that is, $P \& O$ and Lauritzen were going to put ships into the newly founded company Lauritzen Peninsular Reefers (LPR) and operate the ships together. What is important to remember is that Lauritzen had significantly more experience than $\mathrm{P} \& \mathrm{O}$ in the segment. Given that Lauritzen had more experience, most of the staff were from Lauritzen, but there were also people from $\mathrm{P} \& \mathrm{O}$ that joined the company, which was operated from Copenhagen. There were potential synergies - while Lauritzen had a limited presence on the global market, $\mathrm{P} \& \mathrm{O}$ as a liner company had a worldwide network of agents, which could be a valuable support for the highly international reefer trades.

In the negotiation phase, Lauritzen had more reefers than $\mathrm{P} \& \mathrm{O}$, so $\mathrm{P} \& \mathrm{O}$ went to the Norwegian Yard Drammen to build more vessels. P\&O and Drammen jointly built four reefers and they were included in LPR. LPR was also a way for Drammen to continue building reefers. This shipyard even owned reefers that they put into the LPR operation?.

6 Lauritzen News 2007/7, p. 11 .

7 The Drammen manager said: "British P \& O came to Drammen and told us about a collaboration [...] under the name Lauritzen Peninsular Reefers. As the cooperation should be equal, 
LPR thus functioned as a pool operating both Lauritzen's and P\&O's ships, as well as those of Peter Berg, owner of Drammen Shipyard. The collaboration started in 1971. In the beginning, the new company owned 16 ships plus chartered-in tonnage. By 1975, LPR controlled a combined fleet of 25 ships. According to a respondent, LPR was informaly called the "shark's teeth", which is a discursive representation of a young and aggressive organization, in tough competition with Salén. And not the least, LPR saw themselves subjectively as a fierce, and wild, competitor to Salén's and other operators. During this period, from 1978 to 1980, four large, fast sister vessels - the Asian Reefer class were delivered to Lauritzen 8 .

LPR was according to many respondents successful, but in the early 1980 , the mother company $\mathrm{P} \& \mathrm{O}$ was in trouble. The general cargo division of $\mathrm{P} \& \mathrm{O}$ was suffering from the shipping crisis in the late 1970s and early 1980s. In 1978, the fleet list GCD - the general cargo division of $\mathrm{P} \& \mathrm{O}$ - was about 110 ships, and in 1983 all the ships were disposed of. $\mathrm{P} \& \mathrm{O}$ might have been able to keep its operation in the reefer segment, but the reefer market was weak in the early 1980s. Therefore, in 1983, LPR disbanded and Lauritzen continued as Lauritzen Reefers.. P\&Os reefers were sold to the Greek shipowner Comninos and the Singaporean shipyard Sembawang.

Alhough the relationship was discontinued, according to employees of LPR, the experience of the collaboration was good. The company was organized in a fair 50/5o fashion. The two partners were equal and the collaboration between them was very good. Both partners were interested in the reefer segment, and $\mathrm{P} \& \mathrm{O}$ often sent trainees to the office in Copenhagen to increase knowledge about the reefer market. Both representatives of $\mathrm{P} \& \mathrm{O}$ and Lauritzen pointed out, however, that the tonnage that P\&O entered the LPR collaboration with was not good. The ships were perceived to be beautiful, but did not have optimized cargo capacity, and some of them were very unstable in bad

P\&O needed four additional vessels in the fleet. A board decision was made in P\&O to build two ships at Drammen, assuming that Berg would also add two ships into the new constellation, as part of P\&O's fleet. [...] So, the shipyard suddenly received a welcome filling of the order book until 1978. - I got a seat on the board of directors of the new operator in Copenhagen. It gave us the ability to build reefers for ourselves. If the shipyard did not get new contracts, we could continue building reefers and employ them in Lauritzen Reefers Peninsular. And we could also sell ships when the opportunity arose, explains Berg. Following this philosophy the shipyard built reefers to be owned by themselves: Ragni Berg, Elisabeth Berg (in Haugesund), later also Elizabeth B and Cäcilia B Borgen, P.O. and Heieren, R. 2011, Made in Drammen : industrihistorie fra en østlandsby med hovedvekt på perioden 1870-1970, Drammen : Drammen Rotary, p. 125 .

8 Asian Reefer, Balkan Reefer, Canadian Reefer, Ecuadorian Reefer with a hold capacity of 588 ooo cbf each. 
Wild Auk

Wild Avocet

Wild Cormorant

Wild Curlew

Wild Flamingo

Wild Fulmar

Wild Grebe

Wild Gannet
Italian Reefer

Nippon Reefer

Persian Reefer

Roman Reefer

Samoan Reefer

Tunisian Reefer

Chilean Reefer

Ecuadorian Reefer

Iberian Reefer

Sevillan Reefer

weather. It was even explained that one of the ships sailed around with 500 tons of concrete to keep it upright.

Looking at Lauritzen from the corporate level, DFDS was suffering from losses, and its fleet was reduced significantly in the early 1970s, leading to improved profitability. The Lauritzen group entered into the offshore business by buying a drillship in 1973-4, which turned out to be a success. Lauritzen had entered into long-term contracts for the tankers, and the reefer segment was not affected by the more general slump in shipping markets.

The 1970s were marked by the death of Ivar Lauritzen in 1974 and Knud Lauritzen in 1978. When Knud Lauritzen died, the Lauritzen group consisted of 60 Danish and international businesses, with a turnover of 4 billion Danish kroner, and with 12500 employees. The shipping business - shipping services, offshore, and DFDS - stood for 46 percent of the turnover. After Knud Lauritzen's death, the professional managers gained power. The professionalization of Lauritzen led to a corporate structure where, according to Ole Lange's narrative, responsibility was everywhere and nowhere. Many ambitious projects were embarked upon by the new leaders, for example DFDS cruises in the US (New York - Bahamas), which almost led to the demise of the Lauritzen group. To try and save DFDS, not only were the cruise activities dismantled and the newly bought ships were sold - also two rigs and two heavy-lift ships from the profitable offshore business had to be sold. But the problems went deeper, so new equity had to be raised for DFDS. The shipyard business was ailing as well, and this business was restructured, focusing the newbuilding activities to Frederikshavn. 
After the dismantlement of LPR, Lauritzen sought pool partners, and continued to develop the business. In the early 1980s Lauritzen developed a new type of reefer - the ULRC (Ultra Large Reefer Carriers), also called the African Reefer class, or the Jumbo Class. This was a ship type which was developed inhouse by Lauritzen with the input of the commercial and the cargo people. The jumbo ships are sometimes described as boxes with an engine in the aft, and as stable workhorses. These are discursive traces showing that the ships were optimized for cargo space and low bunker consumption, and not as fast nor as beautiful as previous reefer ships. They were designed for 17.5-18 knots.

Although the Italian Reefer series had capacity for carrying pallets, the Jumbo class was the first one explicitly designed to carry pallets, with strong gratings, designed for pallet handlers and forklifts. The ships were also very box-shaped in order to optimize the intake of pallets. The first ones were Anne $B$ and Betty $B$, which were built by the pool partner Finn Bugge in Japan in 1983. Norwegian Finn Bugge had a close relationship to NYK in the 196os and 1970s when he did most of their tanker spot fixtures. People at NYK introduced him to the Tsuneishi Shipyard in Kyushu, Japan, and he ordered a number of tankers in the 1970s. It is within the scope of this long-standing relationship with Tsuneishi shipyards that he built Anne B and Betty $B$. These two ships are called pre-Jumbo ships, since they did not have aluminium gratings for carrying pallets.

After the pre-Jumbos were built, six Jumbo ships followed, four built in 19841985 and two in 1988, owned by pool partners such as Saudi Arabian Company, Sembawang, and Henrik von Platen. Lauritzen representatives recall that Salén were building the Winter ships at around the same time, and that they were beautiful racing ships, but less optimized for cargo and had a significantly higher fuel consumption than the Jumbos. The Salén vessels were regarded as fancy and advanced while the Jumbos were optimized workhorses. This remembrance is a trace showing that Lauritzen perceived themselves subjectively to be more about business than beauty.

The early 198 os was also a time of business development at Lauritzen. A deal that is remembered by a respondent was when Lauritzen tried to break into the South African deciduous exports market. They already had good relationships with Outspan, the citrus exporter, but the South Africa Deciduous Fruit Board was committed to liners and Salén's Snow and Winter classes. Luckily, a new person became the head of the marketing board and wanted to make some changes. Because of the Jumbo ships, Lauritzen could offer rates that were lower than the liners. Salén and Blue Star Line were also interested but it was Lauritzen that picked up the business. 
TABLE 7 The Jumbo vessels

Belgian, pre-Jumbo.

Brazilian, pre-Jumbo.

Australian Reefer

African Reefer

American Reefer

Reefer Jambu

Anglian Reefer, late Jumbo

Argentinian Reefer, late Jumbo.

The main competitor, Salén, was in trouble during the the early 1980s. During Salén's crisis, Chiquita reportedly felt that Salén was not adequately taking care of their business relationship. Chiquita had through the affiliated German banana company Atlanta gained experience with two ships of the Asian Reefer Class. They liked those ships and did a deal with Lauritzen, thus moving business away from its "purveyor to the court". By outcompeting Salén in this prestigious business relationship, Lauritzen subjectively perceived themselves to be number one.

Still, the market was not good, and the reefer division was under pressure from corporate management. LPR was history and Lauritzen now had to handle the investment and operation on its own. Apart from the new Jumbo class, other ships were in the pool, for example as a result of Saléninvest's bankruptcy. Although Lauritzen Reefers had developed its pool since the end of LPR, it was still not earning enough money.

As many companies do in periods of crisis, Lauritzen brought in consultants, from McKinsey, to scrutinise Lauritzen's businesses and suggest ways forward. In 1985, a report was presented by McKinsey about the reefer segment, suggesting two plans, plan A and plan B. Plan A was to dismantle the whole reefer segment, selling all ships, which would lead to an income of 940 million DKK. Plan B was to significantly scale-down the operation. The McKinsey report came as a big blow to the people within the reefer division who thought that McKinsey did not have an accurate understanding of the business. For example, McKinsey suggested that backhaul cargo should be sought for, but did not give any indications about what kind of backhaul cargo was interesting. And the top management was also shocked, calling the suggestion 
to cut back on reefers "a big bomb" which would have severe negative repercussions. The long tradition of Lauritzen's reefer division definitely played a part in the negative reactions to the report. This was of course related to the subjective self-perception that an important part of Lauritzen's DNA was related to reefers. The argument against plan A was that this would lead Lauritzen to be dependent on the offshore sector - a high risk sector. It was decided that Lauritzen should go for plan B. Reefer activities would be cut back and any new investments would be made by pool partners rather than by Lauritzen. In the end, the McKinsey report changed little in the short run, since plan B was already in motion since the early 1980 s. But we believe that the report did establish one thing - the reefer division was no longer a sacred cow.

Problems continued and during 1985 and 1986, there were losses in the range of 70-120 million DKK in the reefer segment. The offshore market also collapsed and Lauritzen recorded a 486 million DKK loss in 1986. At the 1987 general meeting, Ole Lauritzen criticised the company's management, claiming that they had lost 3 billion kroner over the previous nine years. The problems continued. In the summer of 1988, Danyard suffered a crisis that endangered the whole group.

\section{The Family Class and the Weak 199os}

To solve the shipyard crisis, the upper management devised a bold plan: a sophisticated ship that would increase the competitiveness of Lauritzen's shipyards. The development of this ship type was supported by the Danish Ministry of Industry's Project Ship programme, an effort to strengthen the innovativeness of Danish shipyards. Lauritzen's innovative ship, was first conceptualized as a container ship, but later became more and more linked to the fate of the reefer division. A related fact was that the reefer market was improving from 1987. The concrete project was about creating a new type of reefer, with smaller crews, less energy consumption, and less time in port. The ship would have a cargo capacity of $765000 \mathrm{cbf}$ and therefore be the world's largest specialized reefer vessel. Its advanced and automated control systems implied that they could be manned with a crew of just six persons. It later turned out that they required more than this in practice, at least nine, but it was still very low.

The Family Class, as this ship type was called, stemmed from a technology push from the corporate level rather than a real demand in the reefer market. Indeed, top managers at Lauritzen Reefer considered the Family class to be unsuitable for the reefer trades and felt that their opinions about the project were ignored. The negativity within the reefer division towards the Family 
class was not an anti-innovation sentiment, but more a concern about the cost of the new ships. During the unfolding of the project, the two late Jumbo ships Anglian Reefer and Argentinian Reefer were up for sale in the open market for about 17-18 MUSD per ship, which the reefer division considered much more sensible investment than the plan to order Family class ships for more than $5^{0}$ mUSD each. Although the reefer division tried, they could not convince the upper echelons that these were good investments. The upper management had their focus on the Family Class. Related to the subjective dimension of the theoretical framework, they were not only convinced of the business sense of the idea, but given the way the ship was discussed and presented they felt a strong pride for the innovation.

Three large Family class vessels were ordered at Danyard, and later a fourth. The price of the first two reefers was 54 mUSD each. While the first three ships were designed to take laden containers under deck, the fourth one was a stripped-down version of the first three, which led to a price of about $10 \mathrm{mUSD}$ less.

After the Family class vessels had been delivered, there was a conference where the results of the Family class vessels and the Anglian Reefer, a Jumbo class vessel, were tabled on the same graph. Basically the two ships had the same earnings, which was a matter of discontent for the managing director of Lauritzen, since the price of a Family class vessel more than doubled that of a Jumbo vessel. Given this reaction, one might argue that he held a subjective belief that these vessels had to earn more than the conventional Jumbo vessels. For these low earnings, the Reefer division, rather than the Family class vessels, was held accountable.

For the reefer division, the following time was dedicated to increasing the profitability of the Family class vessels, mostly by developing new trades. The reefer division developed a business with Noboa which put the ships on a triangular service from Ecuador to Long Beach with bananas and then citrus to Japan in the compartments vacated by the Ecuadorian cargo, and then managed to find some backhaul business from Japan to South America with cars. According to many, that was the best utilization of the Family class. To handle this triangular trade and make it sustainable over time, several new offices were opened or significantly expanded in Ecuador, Peru, Long Beach and Tokyo, solely for servicing the Family class vessels, which of course also increased cost. Some employees at Lauritzen were very proud of this trade, which they considered one of the first liner businesses in reefer shipping, and that this idea could be exported to the Atlantic. This is yet another sign of the subjective dimension - that the reefer division not only considered the higher profitability of the vessels, but also felt pride because they had a liner business. 


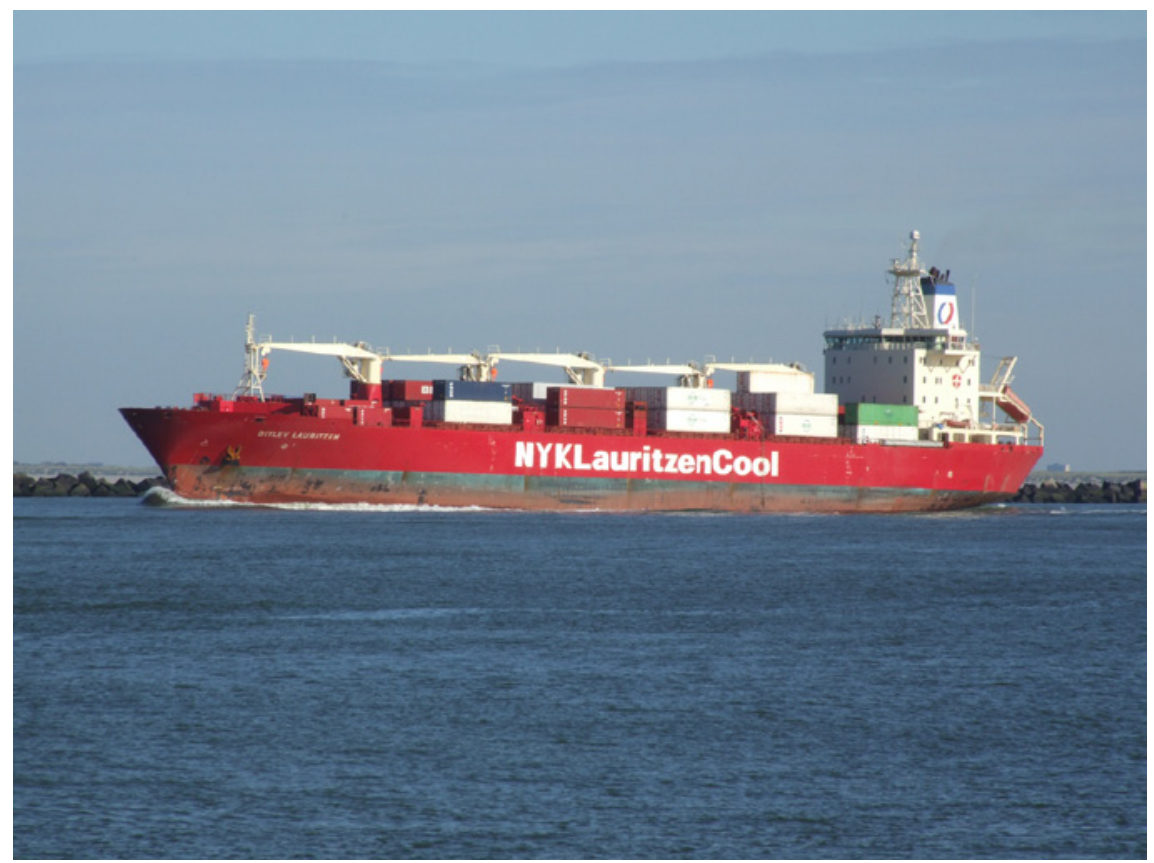

FIGURE 11 The Family Class were controversial, they were innovative but expensive. They showcased Danish shipbuilding and did generate orders for Lauritzen's Danyard, including several vessels for Chiquita's Great White Fleet. The Ditlev Lauritzen is pictured sailing in the Port of Rotterdam, 2005 for NYKLauritzenCool PHOTO: ALFVANBEEM

It is evident that wild newcomers - the independent reefer operators - still subjectively believed that the business of the traditional liner companies was desirable. But notwithstanding the triangular system, the trade was according to some not good enough if you take the building price and fuel consumption of the ships into account.

With the exception of the Family class vessels, the reefer division developed according to its former strategy in the late 1980 s and early 1990s. Apart from expanding the fleet with two Jumbo vessels, Lauritzen entered into an ownership agreement with Gustaf Erikson. Gustaf Erikson was a shipping company from Åland in the Baltic Sea that had operated small reefers in the International Reefer Services pool in Hamburg. They were looking to enter into the segment of larger reefers, which was potentially more profitable and more prestigious from a subjective point of view. Most of the expansion in Gustaf Erikson was attributable to the Norwegian broker Thor Ronhovde. He had appeared as a financier of Gustaf Erikson and wanted to make the company a significant owner and operator of larger reefers. The foundation of this intended transformation 
was the order of a series of ships, the Penguin class, at Kvaerner's Kleven yard. As the delivery drew closer, it became apparent that Gustaf Erikson required additional operational know-how and sought to partner with amongst others, Lauritzen.

\section{Gustaf Erikson}

The Åland-based company bearing his name was founded by Gustaf Erikson in 1913 and acquired its first reefer, Kallsö, in 1950. In 1957, the company built a reefer at their own shipyard in Nystad, Finland. The ships were employed in the spot trade, but also operated a line between the European Continent and Canada and the us. For about a decade, Gustaf Erikson operated a liner service with fruit from Spain to Finland.

In 1977, another three reefer ships were built at the company's own shipyard. In 1978, the company had 16 reefer ships in their fleet with sizes ranging between $50000-90000 \mathrm{cbf}$, and their specialty was carrying deepfrozen commodities ${ }^{\mathrm{a}}$.

Note: a Malmberg and Hag 2013.

Five vessels, one of which was owned by Lauritzen, were added to the Lauritzen pool, a larger version of the Penguin Class, dubbed the Emperor Penguins. The Penguin ships are often described as being good from the engine room forward. The engines were fraught with quality problems but, nevertheless, around 18 ships were ordered in the series. Like many entrepreneurs in the reefer industry, Thor Ronhovde encountered problems in this difficult market situation. The bold entry into the larger reefer segment failed and also ended Gustaf Erikson's history as a shipowner. During this turbulence, Lauritzen bought three more of the Emperor Penguins. The rest of the distressed tonnage ordered by Gustaf Erikson was coordinated through the company WISIDA, to which Per-Olof Oweson - a former Saléninvest and Cool Carriers keyperson was recruited.

For Lauritzen, the addition of the Family Class vessels, the Jumbo reefers, and the Emperor Penguins resulted in a growth of the Lauritzen Reefer pool. From a capacity of 15.4 million cbf in 1988, it grew to 21.5 million cbf in 1993. Peter Weitemeyer, president of J. Lauritzen, commented with pride that "Lauritzen has the most modern reefer fleet in the world"9. But, many other reefer companies expanded during this period, and former Soviet reefers entered

9 “Lauritzen hopes for thaw in ice-cold reefer market". TradeWinds 6 August 1993, p. 10. 
into the international market which caused an oversupply of tonnage. Correspondingly, the market fell from 80 cents per cubic foot/month in 1991 to 55 cents in 1993. Protectionism in the European Union first against the import of apples from Chile and then the favouring of ACP bananas rather than dollar bananas, led to further market depression. Lauritzen's business was disadvantaged by these regulation changes and profitability suffered accordingly.

Like in the early and mid-1980s, Lauritzen Reefer was in the red. At Lauritzen Reefer, much critique was directed at the Family class vessels. In the early 1990s, according to upper management of Lauritzen, they became embroiled in corporate politics, rather than business. In this situation, some top managers in Lauritzen Reefers left the Reefer division to pursue other opportunities. Torben Naesvang and Mikael Lund were the managing directors of the reefer department. Naesvang left for Armada Shipping in 1993 and Mikael Lund was transferred to Kosan Tankers. This is similar to how a number of top executives left Cool Carriers in the early 199os to pursue other opportunities due to a subjective feeling of stagnation, decline, and lack of excitement.

The Lauritzen group was recording losses, 393 million DKK in 1993, and 346 million in 1994. To deal with this crisis, the Lauritzen's new strategy would be concentrate on less segments within shipping. In 1995, the business was focused on chartered-in bulk tonnage, reefers, the Greenland trade, and the gas and product carriers, while the tanker and offshore business segments were dismantled.

After a few years of the newly built Family trade, Lauritzen lost the Noboa contract to Cool Carriers and the circular trade was disrupted. This aggravated the financial problems in Lauritzen Reefer. To assure a stable income from the ships, they were chartered to Cool Carriers. Although the Family class came under critique at Lauritzen Reefers, how did the ships affect Lauritzen's shipyards? The skills and competitiveness of Danyard developed during the Family Class project and led other companies to place orders for similar, but less sophisticated vessels at Danyard. Five ships for DIF Ko for service with Noboa, six 640 ooo cbf reefers were built for Chiquita and two $625000 \mathrm{cfb}$ reefers for Geest. In the time period of three and a half years from 1990 Danyard had built 17 reefers. It has been recounted that these ships have been very successful for their owners. Whether they were profitable for the shipyard is not clear.

Notwithstanding, the results of the reefer division were not good, which put the division under heavy pressure from the upper management. It's told that one of the owners had his office next door to the reefer department, and everyday the reefer employees would hear how unhappy he was with them. There was a requirement from the owners to deliver a $13 \%$ return on investment, which seemed to be impossible. They cut down on unprofitable trades which 
also made the operation smaller. It was no longer of interest to run a pool to earn money for other owners. The Lauritzen pool was terminated in 1996/1997, after which Lauritzen Reefers was established as a stand-alone entity operating tonnage fully owned and chartered by Lauritzen. In this way, Lauritzen also lost the upsides of a pool - to get a wider market presence. The market was not always bad in the end of the 1990s, but the reefer division was still suffering losses. The cost cutting and discontinuation of trades continued and at the end of 1999, Lauritzen Reefers fleet comprised 31 reefer vessels with a total capacity under deck of 16.9 million cbf. In an annual report from 1999, it is written that "Throughout 1999, J. Lauritzen A/S has been advocating consolidation in [...] the [...] reefer markets" and that "With the exception of Lauritzen Reefers, J. Lauritzen A/S expects an improvement in the results of the individual business areas in comparison with 1999."10

The upper management of the reefer division was interested in trying to create something together with some other player, rather than standing back and watching Lauritzen Reefers slowly decay. This is also similar to the development at Cool Carriers, where the upper management tried to find owners and investors that supported the ideas of the organization. In 1998, Torben Janholt became the CEO of Lauritzen. He had experience with reefers and was allegedly very pragmatic in contrast to the previous CEO. He listened to the upper management of the reefer division. Janholt tried to make a joint venture with Höegh but it did not materialize. He approached Seatrade and was prepared to let the new joint venture be placed in the Netherlands, but the two parties could not agree. The solution that was arrived at was to buy Cool Carriers. It was a software organization and could therefore be acquired cheaply compared to creating a joint venture with an organization owning hardware.

\section{LauritzenCool: Two Market Leaders Become One}

At the end of 2000, Lauritzen announced the take-over of Cool Carriers for 35.4 million USD. It was stated in the annual report of 2000 that "Through the acquisition of Cool Carriers AB at the end of the year, JL carried through the long awaited consolidation in the reefer market". ${ }^{11}$ It was further explained that "the acquisition of Cool Carriers $\mathrm{AB}$, forms the natural foundation for JL's continued engagement in reefer transport [...] though its contribution is hardly likely

$10 \quad$ Annual Report Lauritzen 1999, p. 4, 6.

11 Annual Report Lauritzen 2000, p. 6 
to include increased investment in tonnage"12. Since Lauritzen was not interested in increasing its investment in tonnage, they did not buy any of Höegh's ships.

The acquisition of its main rival in the reefer segment was a way to consolidate and to turn red figures into black. Lauritzen Reefer's losses had that very year been about 140m DKK, but the synergy effects from Cool Carriers and Lauritzen's operations was expected to be 15 mUSD per year ${ }^{13}$. The CEO of Lauritzen Reefer at the time was Birger Lindberg Skov. He explained that part of the reason to buy Cool Carriers was to get hold of the income that the Family Class vessels generated for Cool Carriers. A few years earlier, Lauritzen Reefer had chartered these vessels to Cool Carriers, which prided itself in being able to employ the vessels more efficiently and profitably than Lauritzen Reefer. Cool Carriers subjectively derived strong pride from their market and trade knowledge.

When the announcement came, the staff at Cool Carriers were shocked. A Cool Carriers employee said: "We were petrified. Lauritzen was our worst competitor." At the same time in Copenhagen there was a meeting in which it was declared that Lauritzen bought Cool Carriers, but rather than moving the operation to Copenhagen, the new head office was to be in Stockholm. Mats Jansson, head of Cool Carriers, stated that it was remarkable that Lauritzen accepted that the new company, LauritzenCool, would be based in Stockholm. Indeed, it's not the usual way of doing things when one buys a competitor's operation.

A few Lauritzen employees started working in Stockholm. A top executive from Lauritzen explained that he thought that the Stockholm office had a better management structure than the Lauritzen office, which as we know, had been in quite some turbulence during the 1990s. He also looked forward to work with Mats Jansson and Lars Rutberg, two experts within the reefer industry. Other former employees from the Copenhagen office joined Arctic Reefers, which had been established in Stockholm, but now moved its headquarters to Copenhagen. Arctic Reefers, as we have explained earlier, had an identity as a profitable but second-tier operator due to its old tonnage.

That Lauritzen and Cool Carriers joined forces was seen as a good move from the perspective of both organizations. The fleet size increased. Competence from both organizations could be utilized. Lauritzen had a good network in South America. In Argentina, Lauritzen and Cool Carriers were more or less equally strong, but Lauritzen was stronger in Chile and in Brazil. While Cool

\footnotetext{
$12 \quad$ Annual Report Lauritzen 2000, p. 6-7
}

13 Annual Report Lauritzen 2000, p. 6-8 
Carriers had worked with large exporters from Chile, Lauritzen had developed their own liner services from Chile, having good contacts with both larger and smaller exporters.

From the perspective of the Stockholm office, Lauritzen's ownership was quite hands-on. They wanted to implement their own systems in LauritzenCool. Furthermore, many cultural differences were perceived between Danes and Swedes, for example that the Danes were more deal-driven than the Swedes who wanted a systematic, functioning operation of the ships, and that the Danes were faster than the Swedes, and that the Danes were more prone to loud discussions and voicing of opinions than the Swedes.

Deregulation of export and import markets had now progressed, and in an interview Mats Jansson explained that this posed demands on LauritzenCool. Rather than being a provider of transport capacity, LauritzenCool needed to be able to offer full transport solutions to a larger number of smaller customers. Given this change in the competitive landscape, LauritzenCool Logistics (LCL) was created. The idea was to offer intermodal door-to-door transport for refrigerated cargo. The maritime transport could be done by any of LauritzenCool's reefers or sometimes with container lines. LCL grew and was seen as a core part of the new LauritzenCool.

Furthermore, the threat from container lines had become significant. Many larger container lines had now increased their capacity to carry refrigerated cargo on North-South routes, rather than focusing on East-West routes. How would LauritzenCool compete with the container lines? Mats Jansson stated:

In several ways, and partly by joining the concept. Our reefer vessels have significantly increased their capacity for carrying containers on deck. We have also extended our liner services. Our advantage is shorter transit time: we make few port calls, whereas the container lines have many scheduled ports to visit. We also have greater flexibility: should a customer quickly need additional capacity, we can send an extra reefer ship to meet that urgent need - not to mention a change of port destination at short notice. ${ }^{14}$

He concludes that the question whether reefers or container will win out was the wrong question. Instead, the two alternatives should be described as "specialized reefer operators with full focus on carriage of perishable cargo, under deck and in reefer containers on deck" and "container lines carrying reefer containers in addition to their core business". And the relevant question was

14 LauritzenCool in perspective, p. 3-7. 
whether specialized reefer operators would be able to match the global container lines in offering the most competitive solutions for the overseas shipment of reefer cargo. Here it is clear from a discursive perspective that Mats Jansson believed that the way the reefer industry spoke about reefers vs container lines was not fully adequate - in other word, the discourse does not match the material dimension of the theoretical framework. One needs to change the discourse in order to truly understand what is at stake.

TABLE 8 LauritzenCool's fleet in 2003 (excluding ReeferShip)

\begin{tabular}{|c|c|c|c|}
\hline Class/Name & Cbf & Built & Reefer container plugs \\
\hline \multicolumn{4}{|l|}{ Family Class } \\
\hline Ditlev Lauritzen & 759 ооо & 1990 & 184 \\
\hline Ivar Lauritzen & 759 ооо & 1991 & 184 \\
\hline Jorgen Lauritzen & 759 ооо & 1991 & 184 \\
\hline \multicolumn{4}{|l|}{ Jumbo Class } \\
\hline Belgian Reefer & 691000 & 1983 & 68 \\
\hline Brazilian Reefer & 691000 & 1984 & 68 \\
\hline Swan Chacabuco & 677 ооо & 1990 & 45 \\
\hline Amer Choapa & 674000 & 1987 & 45 \\
\hline Chaiten & 674000 & 1988 & 54 \\
\hline \multicolumn{4}{|l|}{ Island } \\
\hline Dominica & 644000 & 1993 & 108 \\
\hline St. Lucia & 644000 & 1993 & 108 \\
\hline \multicolumn{4}{|l|}{ Tundra } \\
\hline Tundra Queen & 596 ооо & 1991 & 129 \\
\hline Tundra King & 595000 & 1991 & 129 \\
\hline Tundra Princess & 595000 & 1991 & 129 \\
\hline \multicolumn{4}{|l|}{ Lady } \\
\hline Lady Korcula & 590 ооо & 2000 & 120 \\
\hline Lady Racisce & 590 ооо & 2000 & 120 \\
\hline \multicolumn{4}{|l|}{ Hansa } \\
\hline Hansa Lübeck & 592000 & 1990 & 80 \\
\hline Hansa Stockholm & 592000 & 1991 & 80 \\
\hline Hansa Bremen & 590 ооо & 1989 & 80 \\
\hline Hansa Visby & 590 ооо & 1989 & 80 \\
\hline \multicolumn{4}{|l|}{ Summer } \\
\hline Summer Meadow & 590 ооо & 1985 & 82 \\
\hline
\end{tabular}


TABLE 8 LauritzenCool's fleet in 2003 (excluding ReeferShip) (cont.)

\begin{tabular}{|c|c|c|c|}
\hline Class/Name & Cbf & Built & Reefer container plugs \\
\hline Summer Flower & 590 ооо & 1984 & 82 \\
\hline Summer Wind & 589000 & 1985 & 82 \\
\hline Summer Bay & 589000 & 1985 & 82 \\
\hline \multicolumn{4}{|l|}{ King Ivories } \\
\hline Atlantic Reefer & 601000 & 1998 & 61 \\
\hline Pacific Reefer & 601000 & 1999 & 61 \\
\hline Ivory Girl & 566 ооо & 1996 & 70 \\
\hline Polarstern & 564000 & 1999 & 104 \\
\hline Polarlicht & 564000 & 1998 & 104 \\
\hline \multicolumn{4}{|l|}{ Ivory } \\
\hline Ivory Nina & 527000 & 1990 & 30 \\
\hline Ivory Dawn & 527000 & 1991 & 30 \\
\hline Ivory Tirupati & 527000 & 1989 & 30 \\
\hline Ivory Ace & 527000 & 1990 & 30 \\
\hline Mexican Reefer & 527000 & 1994 & 44 \\
\hline \multicolumn{4}{|l|}{ Reef } \\
\hline Polar Chile & 537 ooo & 1993 & 47 \\
\hline Polar Uruguay & 537000 & 1993 & 47 \\
\hline Polar Colombia & 529000 & 1992 & 47 \\
\hline Polar Ecuador & 529000 & 1992 & 47 \\
\hline \multicolumn{4}{|l|}{ Mountain } \\
\hline Amer Whitney & 508000 & 1990 & o \\
\hline Amer Himalaya & 503000 & 1990 & 14 \\
\hline Amer Fuji & 502000 & 1990 & 14 \\
\hline Amer Everest & 495000 & 1989 & o \\
\hline Amer Annapurna & 478 ооо & 1987 & 66 \\
\hline Rapa & 461000 & 1990 & 25 \\
\hline Atlantik Frigo & 460 ooo & 1989 & 25 \\
\hline \multicolumn{4}{|l|}{ Emperor Penguins } \\
\hline Chilean Reefer & 424000 & 1992 & 42 \\
\hline Peruvian Reefer & 424000 & 1992 & 42 \\
\hline Scandinavian Reefer & 424000 & 1992 & 42 \\
\hline Packer & 378 ооо & 1990 & 80 \\
\hline Planter & 378 ооо & 1989 & 80 \\
\hline Transporter & 378 ооо & 1990 & 80 \\
\hline
\end{tabular}


TABLE 8 LauritzenCool's fleet in 2003 (excluding ReeferShip) (cont.)

\begin{tabular}{llll}
\hline Class/Name & Cbf & Built & Reefer container plugs \\
\hline Crystal & & & \\
Pride & 376 ooo & 1992 & 29 \\
Primadonna & 375 ooo & 1992 & 29 \\
Privilege & 375 000 & 1992 & 29 \\
Prince & 375 000 & 1992 & 29 \\
& & & \\
\hline
\end{tabular}

Fleetwise, the focus of LauritzenCool was still on top quality, modern tonnage. Regarding the second-tier, older tonnage, consolidation was sought in collaboration with other parties. In 2002, the venture ReeferShip was established by Arctic, Eastwind, and Armada Shipping, employing 53 ships in the size range of $220000 \mathrm{cbf}$ to $600000 \mathrm{cbf}$.

Mats Jansson tried to initiate newbuilding projects to renew LauritzenCool's tonnage but the board showed little interest. The Pallcon ship - the sideloader with container capacity - which was developed by Cool Carriers was presented to the board but did not make an impact. Jansson explained that: "I suggested how LauritzenCool ought to develop for the Lauritzen board. They did not want to invest in reefers while they invested heavily in other sectors. I noticed quite early that reefers are not prioritized." Gradually, it started to seem as if Lauritzen had acquired Cool Carriers as a way to exit the segment. No new tonnage was acquired.

In 2004, the feeling that Lauritzen was on its way to exiting the industry was confirmed. Lauritzen was successful in its other segments, such as bulkers and short-sea ro-ro, and had by this time decided that there was no future in reefer shipping. Because of this the upper management had looked around for other potential owners of the operation. One such possibility was presented by a former key person at Cool Carriers - Lars Rutberg - who for some years had been working for NYK Reefers. In 2004, LauritzenCool entered a tonnage sharing agreement with NYK Reefers and NYK Reefers bought 50\% of LauritzenCool Logistics. LauritzenCool and NYK struck a deal to create a joint venture, and in January 2005, NYKLauritzenCool was created. The company employed around 60 specialized reefer vessels ranging from 300 000-76o ooo cbf with additional capacity for reefer containers on deck, equivalent to about $20 \%$ of the under-deck capacity. NYK knew from the beginning that Lauritzen was going to exit the segment but agreed that a three-year phase out was suitable for both parties. 
Lauritzen finally ended its long-standing presence in the reefer segment when it sold its share of NYKLauritzenCool to NYK in $2007^{15}$. Torben Janholt was praised at Lauritzen for being able to exit the reefer segment in such a successful way. A gradual decline of Lauritzen would not have led to the same financial outcome.

TABLE 9 Turnover of Lauritzen Reefers (in mDKK 1998-2002 and in mUSD 2003-2007)

\begin{tabular}{|c|c|c|c|c|c|c|c|c|c|c|}
\hline Year & 1998 & 1999 & 2000 & 2001 & 2002 & 2003 & 2004 & 2005 & 2006 & 2007 \\
\hline Turnover & 1688.4 & 1405.6 & 1437.1 & 3900.6 & $\begin{array}{l}3342.9 \\
(423.4 \text { USD })\end{array}$ & 466.7 USD & 439.0 & 96.3 & 74.0 & 48.6 \\
\hline Net result & -280.2 & -9.0 & -157.0 & 2.7 & -96.7 & $\begin{array}{l}\text { ordinary } \\
\text { before tax } \\
6.5\end{array}$ & 15.1 & 36.0 & 13.2 & 5.8 \\
\hline
\end{tabular}

Lauritzen's difficulties in the 199os encouraged its employees to think about pursuing other possibilities. In September 1993, Torben Naesvang and Carsten Hansen decided to start working with Armada Shipping (based in Fredensborg, Denmark). Armada were also in the reefer segment having bought a company called Mortensen and Lange, which was the owner of Copenhagen Reefers. Copenhagen Reefers consisted of very specialized ships, small sideloaders, basically carrying fish in the North Atlantic, North Sea, and the Baltic. Copenhagen Reefers had a fleet of four ships, one built in 1985, and three in 1990-1991. But Armada was interested in doing something more on the reefer side of business. Carsten Hansen explained that "we had free hands to develop the business". The market was depressed and that can be a suitable time to enter the market.

Armada Reefers started to take some ships on charter, smaller ones and then gradually bigger and bigger. In 1996, the company started buying ships. In the same year, Armada bought the three Dutch Prince types ships (stemming from the operation of Antony Veder). Also in 1996, Armada acquired two Jumbo vessels, American Reefer and Reefer Jambu, that they believed were the most profitable vessels in the Lauritzen fleet. According to TradeWinds ${ }^{16}$, they paid

\footnotetext{
15 JLauritzen. Annual Report 2007.

16 "Armada linked to reefers this time" TradeWinds 25 April 1996.
} 
between USD 17.5m and USD 18m for each ship. Also, the two Japanese ships Amber Atlantic and Amber Pacific (both built 1989, 300 ooo cbf) were bought from the owner Sumitomo, operated by Kyokuyo which was slowly exiting its reefer shipping business. The ships traded worldwide. With the Prince type vessels citrus was carried from Argentina/Uruguay to St Petersburg. Other ships traded with grapefruit from Florida to Japan, from New Zealand with apples and dairy, and various fish trades in the Far East. In 1996, the fleet amounted to 13-14 ships.

The office was moved from Fredensborg to Switzerland, where the rest of Armada's business was located. This was a move to consolidate and to cut costs in a very weak period in the shipping markets. During its first years, Armada Reefers played a role in the reefer market as an outsider to the large players such as Cool Carriers. Shippers are often interested in creating a functioning market that is not oligopolistic, which benefited players of the size of Armada, and also Holy House Shipping. Although the reefer business of Armada was developed by ex-Lauritzen employees, the relationships were kept with Lauritzen - for example the Jumbo ships were chartered to Lauritzen.

When Lauritzen and Cool Carriers merged, Arctic Reefers moved to Copenhagen and some former employees from Lauritzen joined. Armada decided to join Arctic creating a new company called ReeferShip in 2002 - a collaboration between LauritzenCool, Eastwind, and Armada. ReeferShip had a fleet of over $5^{0}$ ships, which were more spot oriented than the operation of LauritzenCool. Therefore, once again the reefer employees of Armada moved back to Denmark. The head of Arctic Reefers was Jerker Nilsson, from the Cool Carriers sphere. The company was founded in a weak market. The market improved and along with it, the pool's results. However, LauritzenCool's new partner, NYK, was not interested in running a second-tier operation such as ReeferShip. As a condition for them buying $50 \%$ of LauritzenCool, they wanted ReeferShip to be dismantled. As for Eastwind, they thought that they could navigate the bullish market by themselves. In 2005, the history of ReeferShip ended.

In 2005, Maestro Shipping bought Arctic and renamed it Maestro Reefers. Since 2005, Maestro has sold its Prince vessels as well as the small reefers stemming from Copenhagen Reefers. Maestro has since then been a self-sufficient operation keeping technical management and crewing in-house. They take a long-term view on ship maintenance, and in an interview in 2015, said that their vessels can go on for another 5-10 years. 


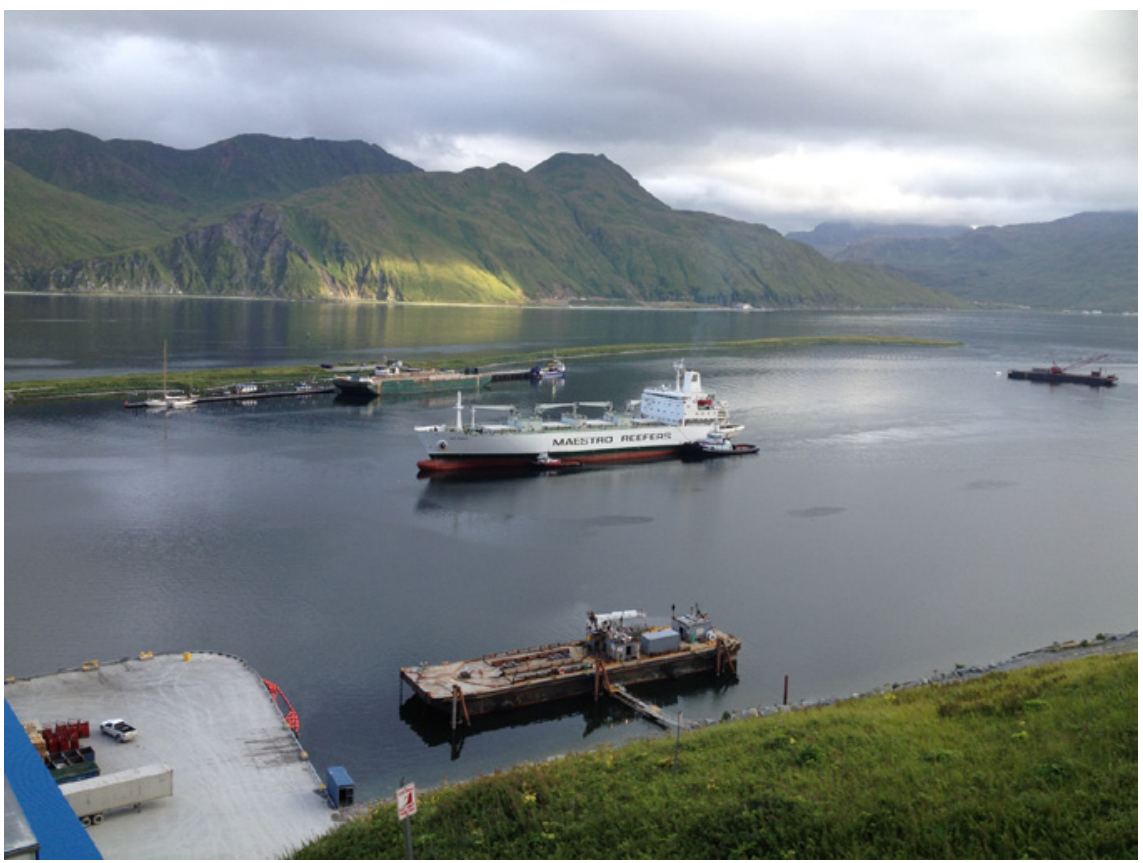

FIGURE 12 Maestro Reefers operate Jumbo-class vessels that had proven themselves with Lauritzen. Ice Rose, on time charter to Alaska Reefer Management, arriving in ballast in Dutch Harbour, Aleutian Islands 2012 to load frozen fish for East coast Canada and Europe

Lauritzen's reefer operation grew out of its general cargo business in the 1920s, converting ships to ventilated fruit carriers and later to reefers. In the early 1930s, Lauritzen started to trade across the Atlantic, over a decade before Salén. There was a subjective belief in fleet renewal, in this growing market. The Second World War took its toll on Lauritzen's reefer fleet, but as soon as the market started to grow again, Lauritzen ordered newbuildings. Similar to Salén, Lauritzen constantly added tonnage in the 1950s and 1960s in order to cater to the global demands of refrigerated transport. Also, similar to Saléninvest, Lauritzen diversified into various shipping segments as well as shipyards. To gain a larger market presence, LPR was created as a 50/50 partnership, which is different from the concept of Salén, where the whole operation comprising other shipowners' vessels was controlled by Salén. Lauritzen was during the 1950s and onwards smaller than Salén, and of course smaller than the liner 
companies, which is expressed through the discourse of the wild operator "the shark's teeth". Lauritzen also subjectively was proud of the state-of-the-art ships and high-class operations.

Similar to Salén, Lauritzen's general profitability was ailing after the 1970s oil crises and the reefer division was put under pressure from the mid-1980s. Still, they were given leeway to invest in efficient tonnage, which according to the subjective beliefs was a movement from the beautiful reefers to the efficient reefers. They even discursively drew on the ULCC tanker concept (which carries a unit of oil cheaper than any other ship due to its size), calling their reefers ULRC - Ultra Large Reefer Carriers.

Lauritzen's reefer operation was in the late 1980s and throughout the 1990s affected by being within the Lauritzen group. They received funds to invest in the ULRC but they had to invest in the Family class against their will, a newbuilding project which tried to exploit synergy effects within the group, but was seen as too expensive and too sophisticated by the reefer division who were now subjectively believing in the ULRCs. The profitability which never was enough for the upper management and the dominance of politics over business, led some core employees to leave the organization and pursue other more subjectively exciting opportunities. Towards the end of the 1990s, the reefer division was decreasing in size, and it seemed to be gradually disappearing. To counteract this, the upper management of the reefer division suggested the bold step to merge with Cool Carriers and was heard by the CEO of Lauritzen.

Lauritzen and Cool Carriers had complementing customers and ships, but the merging of two proud organizations was not a simple task manifesting itself in discursive references to cultural differences and different national business styles. Lauritzen had from the beginning expressed that they would probably not invest in tonnage, and when this became increasingly clear to the upper management, they subjectively felt hindered, and started to "look around for new owners". In this period of consolidation, where NYK had just exited a collaboration with Star Reefers, to take over the LauritzenCool operation looked like a good option - something that we will discuss further in the part about NYK. 


\section{Seatrade}

The Netherlands is famous as a maritime trading nation. This is a rich history filled with the exploits of shrewd merchants, brave explorers and great shipping companies and even today, Rotterdam is Europe's biggest port. But Seatrade doesn't really share this heritage, and its roots are not spectacular, in fact they are more mundane. It is in local shipping, with coasters, mainly plying the waters and riverways of Northwestern Europe, that we find the mercantile milieu that gave rise to Seatrade ${ }^{1}$.

There had been a long tradition in Groningen, in the North of the Netherlands, of coastal trade. Part of the province originally consisted of peat moors. Ditches were built to drain the moors and in time the ditches were enlarged so that barges could ferry the peat to various markets. Subsequently ports and shipyards were located inland amongst the canals that crisscrossed the land. The size of the vessels constructed was necessarily small; the width of the canals limited their size. Transporting peat outwards, the captains sought cargoes for the return trip, and thus a modest shipping industry was born. These coasters were small vessels carrying dry cargo and were usually in the hands of captain-owners who sometimes sailed with their families onboard. Local farmers were not infrequently investors. The vessels, even well into the twentieth century, were sailing ships: spritsail barges - "tjalks" - and later schooners as well. Several people who sailed in this era were the ancestors of people that feature in the history of Seatrade and in several cases their surnames crop up in later years (Tammes, Schuur, Pepping, De Wit). Rebuilding Europe after the Second World War created a boom for the dry coastal trade and many vessels were constructed. The consequent cooling of the market after a few years was the context in which Seatrade was born.

1 This part on Seatrade is based on Peerbolte, H. (ed). 1991. Seatrade 1951-1991, Groningen: Seatrade, Gorter, D. 2012. Nederlandse koopvaardijschepen in beeld - Seatrade, Alk B.V., articles in Simply Seatrade, for example Tom Tammes recollections of his career at Seatrade ("My 60 years of Seatrade". Simply Seatrade 2011) as well as Willem de Bruijn's ("Willem de Bruijn". Simply Seatrade 2008, December, p. 7), articles from Svensk Sjöfarts Tidning and Tradewinds, and interviews with Seatrade former and present management. 


\section{Scheepvaartkantoor Groningen: from Coasters to Reefers}

Five captain-owners met at the Café Bleeker in Groningen on the $24^{\text {th }}$ February 1951 and started the company Scheepvaartkantoor Groningen (SKG), the same company that later became Seatrade. The five: E.H Schuur, C. Tammes, R.T. Tammes, J. Tammes and C. Lente were all in their thirties and now lived ashore. In his inaugural address E.H. Schuur spelt out the conditions that suggested the opportunity they were about to create. In the past captains had arranged their own cargoes. Faster ships and faster handling in ports had deprived the captains of the possibility to do this; there just was not time. Instead, more of the action had been placed in the hands of brokers. Schuur's point was that the assembled captain-owners could do this for themselves and regain control over their vessels and, of course, the profits. The business started with a handful of coasters and an office in Groningen. The aim was to fix the vessels on time-charters to secure stable income in the competitive market. New ships were built, but the attitude was always conservative and external financing was used with caution. The cargoes consisted of wood, coal, clay, steel, grain, fertiliser, and potatoes. The number of ships in the mid-fifties was exceeding fifteen, and it was at this point in time when the first pool was created. Tom Tammes, son of C. Tammes recalls: "In order to avoid that ships (in particular the 1 ooo-ton ships) would compete against each other internally, it was de-

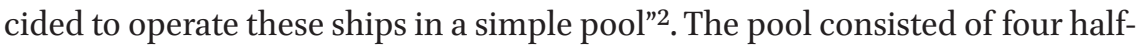
shelterdeckers of about 1000 ton. The idea of having a pool with vessels of similar capabilities is something that comes back to us in more recent times.

In the late 1950s, the era of small coasters was coming to a close and many shipping companies never survived. One strategy was to specialise in a growing segment such as gas tankers or reefers. Pinkster Shipping of Dublin had just built a reefer at a shipyard in Groningen, Nieuwe Noord Nederlandse Scheepswerven, which was going to operate between Ethiopia and Italy for De Nadai, and according to Kees Tammes ${ }^{3}$, the captain-owners were impressed. The decision was clubbed at the meeting on 2 December 1960 and the first reefer was ordered from the same yard, locally in Groningen: the Arctic.

The ship, which was delivered in 1962, had $62000 \mathrm{cbf}$ of reefer space, about a tenth of the larger vessels trading today, and a speed 12.5 knots as compared to about 20 knots today. The Arctic, on her maiden voyage, was chartered to Dammers \& Van der Heide, a significant player in the reefer market and a name that will so importantly return to us in a few years as we continue this

2 "My 60 years of Seatrade". Simply Seatrade 2011, August, p. 6.

3 Peerbolte 1991, p. 50. 


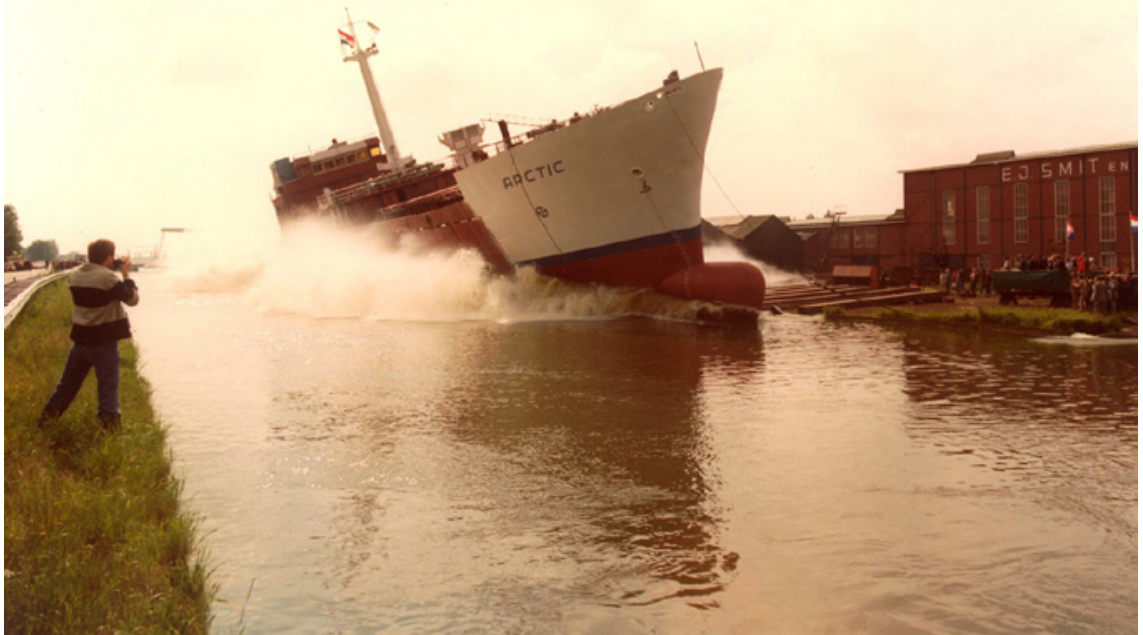

FIGURE 13 The launching of the second Arctic in Westerbroek, Groningen, 1978. PHOTO: SEATRADE

narrative. After being employed for a year in various trades, she got a timecharter for two, three years for Pescanova, trading between Cape Town, South Africa and Vigo, Spain. Marnix van Overklift comments: "It was a good start to fix the ship to a prominent company". The Spanish company Pescanova had found an abundance of hake along the coast of South Africa and Namibia, then still called South West Africa, and needed capacity to carry back the frozen fish to Spain.

More reefers followed such as the Tempo in 1963, also chartered by Pescanova, and the Pacific in 1965, both faster at 15 knots, and alongside with the increase in the reefer fleet, the coasters were gradually sold off. The Tempo and the Pacific were often time-chartered through the London-based reefer broker Andrew Olszowski in the company J.S. Hamilton, to Algerian and Moroccan citrus exporters as well as to Miguel Mico - a reefer broker and operator in London. Assisting Olszowski was the young Tom Tammes, who married his daughter Margaret Mico. Already at J.S. Hamilton, Tom Tammes noted that although the ships were employed 6-7 months in the citrus business, it was vital to get employment during the Northern summer. For this off-season trade, the North Atlantic would be a perfect arena. 
At the end of 1967 Tammes started to work at SKG and was instrumental in setting up the reefer pool. To secure the off-season trade for the reefers, Tammes managed to fix the first North Atlantic voyage: "In 1967 one of the first North Atlantic voyages was fixed through Nils Thorstad with frozen fish from North Norway to Gloucester, Massachusetts, USA where father and son Frank Elliott took care of the stevedoring and distribution of the cargo"4. The Elliott family developed a longstanding relationship with Seatrade extending as far as some investment in tonnage.

The first North Atlantic voyage was in some respect the symbol of a new beginning. Scheepvaartkantoor Groningen began to take control over its own vessels. As a complement to chartering out to others they began to engage in the fish trades. A major trade for the company at the time was the transport of frozen fish (mainly frozen codblocks) from Norway, Denmark and Poland to Gloucester, Massachusetts USA. Gloucester was at the time the distribution point for all fish on the USA's East Coast. On the return voyage the ships occasionally picked up fish offal from Newfoundland destined for the mink farms in Sweden and Finland. These trades were frequently carried out at small ports, with tiny wharves and no stevedoring facilities to speak of.

There were 12 reefers sailing in the fleet in 1973 when the company changed its name to the more internationally palatable Seatrade Groningen. Seatrade had grown and the workload was increasing, but it was still a small company. Marnix van Overklift joined the company in 1973, but he already knew S KG well by that time. His father owned a few coasters and one of them came into SKG chartering operations in 1960. Marnix therefore knew Tom Tammes well and also Tom's brother Kees. When Marnix van Overklift started to work in a shortsea shipping company in Amsterdam at the end of 1968 he was responsible for managing three general cargo ships. One of the ships, which had a hold for reefer cargo, was trading between Morocco and Rotterdam for many years, and Marnix developed a liking for reefer business. He also took care of the manning and operation of the family's ships, since he noticed that the "quality of seafarers is vital", especially in the reefer segment. To secure high-quality seafarers, he learned from Seatrade. Marnix explains that "Wim Blaauw who ran the personnel department was a friend of mine, because his father was a partner in a ship with my father." Therefore, Marnix borrowed crew now and then from

4 "My 6o years of Seatrade". Simply Seatrade 2011, August, p. 7. 
Seatrade. In 1973, the personnel manager told Marnix that "Tom Tammes wants to meet you", and Marnix joined Seatrade soon after. From Tammes' point of view, there was a need for new personnel at Seatrade:

After the delivery of the newbuilding Leo Polaris (90 ooo cbf) in 1970, the reefer market for the smaller ships dropped and instead of having new ships built, several existing ships were purchased. Some of these ships were the ex Horn ships of around 60 ooo cbf. Because of the increased work, I asked Marnix van Overklift to join us at SKG in 1973, killing two birds with one stone since he brought three ships along5.

Marnix joined a company where "things were running like they were". It was not the case that Marnix and Tom radically wanted to transform the company, and had clear ideas how to do it. But still, there was a subjective feeling that the former owners were not entrepreneurial enough and more action was required. No doubt this had to do with their age - they were ready for retirement. They objected to business travel and felt this was expensive and had doubts about the necessity of it. Marnix once wanted to travel to New York and Schuur said "is that necessary?" Marnix said:

I managed to convince him and I booked an excellent paying cargo and ending up with a vessel up in Papua New Guinea, then I sold the ship for good to Indonesia. Had I not built up this contact with this particular broker, this deal would not have happened.

Furthermore, in the 1970s, new opportunities were identified and the fish trades developed, which further strengthened the will of the new generation to take command. The major event in the mid-1970s was the extension of national economic zones to 200 nautical miles which forced many European trawler fleets to seek new fishing grounds. The outcome, particularly for Dutch fishing companies since herring fisheries were practically closed due to low stock, was that the targeted species became mackerel and horse mackerel which was of less interest to traditional markets. This combined with existing fish surpluses in the European Economic Community were factors that made West Africa a market for European fish exports. Nigeria, with its population and oil, was the dominant new market in Africa. Seatrade, through their broker in Norway, Nils Thorstad, got in touch with the Nigerian-Indian company Inlaks which started importing frozen fish in the mid-1970s. This is the start of Seatrade's long

5 "My 6o years of Seatrade". Simply Seatrade 2011, August, p. 7. 
association with the transport of fish cargoes to West Africa. Also at that time a Swedish trading company called Joint Trawlers from Helsingborg developed strongly and with this company Seatrade entertained a lot of business to West Africa. Van Overklift explains:

The West Africa trade which started in 1974-1975 was quite a drive for us. I travelled quite a few times with Walter to Nigeria, meeting customers and potential customers. That's how the know-how develops, you learn who is who, who's fishing, who's buying, etc. It was a big export of mackerel from Holland, as well as from Norway, Scotland, Ireland and Mauretania. Nigeria was in the late 1970 importing up to 800000 metric tons of frozen fish per year. We were heavily involved in contracts with exporters but also with importers, fish from Norway, Ireland, Scotland, Shetland Islands, and Holland to Nigeria. We even once had five ships simultaneously in Lagos, discharging fish. We might have done 250-300 ooo tons of frozen fish to Nigeria only. That was important.

Seatrade maintained its relationships to the Dutch pelagic fishing companies such as Jaczon of Scheveningen, Parlevliet \& Van der Plas of Katwijk, Cornelis Vrolijk of Ymuiden and W. van der Zwan of Scheveningen - well-organised trawling companies, operating large freezer trawlers in the North Sea, Atlantic Ocean, Morocco and Mauretania, as well as the West Coast of South America.

The perceived conservatism of the owners and the plethora of opportunities in the market led to the younger generation taking over the company in 1976. The new owners were Tom Tammes, Henk Schuur, and Marnix van Overklift. Henk Schuur was the son to E.H. Schuur and was a naval architect and the head of the technical department. Tom Tammes had been instrumental in setting up the fish trades in the North Atlantic, in fact he was known as a cold water man. This management buy-out did not include the ownership of the vessels. The old owners were offered a profit-share in return for the stock and could look forward to retirement as the new guard took over.

Seatrade were on the lookout for ships, customers, and know-how. An important step was taken when Geert Pepping was recruited in 1977. The Pepping family had a long history in shipping. Geert's father had joined Dammers \& Van der Heide in $195^{1}$ and had retired as the director of the technical department in 1973. Geert Pepping worked in the chartering department of the same company before joining Seatrade. Marnix van Overklift knew Geert Pepping since they fixed ships from time to time for the transport of tuna. Van Overklift explains: 
I thought it was good to bring in somebody else, and Dammers was at that time quite experienced with larger ships. We felt that in the long run you would have a better economy on larger ships than on smaller ships. And I thought it would be good for the company to have an addition in the chartering department and see how we could grow the company, so I invited Pepping to join as a chartering man.

Dammers were more advanced than Seatrade in the business of transporting fruit and operating larger reefers. Pepping brought knowledge and experience with the fruit business, which is the largest segment within the reefer business. He brought with him a few vessels owned by his family. He had a relationship with an important customer: the major Italian fruit trader Orsero-Fruttital/ Simba. Although Seatrade transported fruit, it is with Geert Pepping's knowledge and contacts with the large-scale fruit trade that the foundations were laid for later expansion into the larger size reefer segment. And indeed, after a few years, Pepping's contributions were deemed substantial and he became a partner together with Tammes, Schuur and van Overklift. However, although know-how is a necessity, larger and also more modern vessels were required to make serious inroads into the fruit trades, for example the seasonal trades from Argentina, Chile, New Zealand, and South Africa. It would take about five years until the building of the N-type "fruit carriers". Seatrade continued to develop its business in the fish trades.

Spanish fishing companies in conjunction with local operators had been fishing in Argentinean waters since at least the early 1970s. This fish was mainly Merluza, otherwise known of as Argentinean Hake, a highly sought after fish. This was mainly exported to Spain, Italy and the USA. Also, shrimps were carried to Spain.

In 1978, Marnix van Overklift was travelling in Argentina with the Salén representative Thorsten Klenell. Klenell introduced Van Overklift to fishing companies for a trade from Argentina and Uruguay to Gloucester, Massachusetts. This trade was serviced by liner companies and could be a market for small vessels, which did not interest Salén. Seatrade made the deal and the trade became important for the company. Some years they freighted close to 200000 tons of fish between South America and Gloucester. These fish shipments were first picked up at La Paloma in Uruguay. This fairly small port had a bar in the harbour that limited the draft of the vessels that could enter. La Paloma was 
therefore the first port of call while the reefers were lightly laden. The vessels then proceeded to Mar del Plata, filled up with cargo and then sailed for Gloucester. The parcel-service from Argentina called at several predetermined ports but without a fixed schedule, like a liner service.

This trade was developed together with the shipping agent Hector Gato of Oceanida, who "knocked on Marnix' shoulder" in Montevideo. He was representing Reefer Express Lines, but he offered to represent Seatrade as well. Together with Hector Gato, the fish business from Argentina to Europe and to West Africa and USA was developed. Marnix: "We were loading a lot of fish: up to 200000 tons a year from Argentina from Southern ports to Spain and then Italy. Later the cargo for Italy was discharged in Eemshaven in Holland and trucked to Italy."

The ultimate integration of the Atlantic fish trades was the route Argentina - Gloucester - Northern Europe - West Africa - Argentina, although the trade to the Us East Coast lasted not for many years, since the volumes were not enough. In Northern Europe the vessels loaded mackerel or herring in ports in the U K, Netherlands and Norway and sailed to West Africa, mainly Nigeria, but also to the Ivory Coast, Ghana, Togo, Cameroon and Angola. There were usually lengthy delays at the Nigerian ports but having discharged the vessels proceeded, usually in ballast, to Uruguay and Argentina to once again load fish bound for Gloucester or Europe. So this trade was a circular one, the vessels making an enormous clockwise tour of the Atlantic Ocean. An alternative was that the vessels, having discharged in West Africa, would proceed to Abidjan in the Ivory Coast to load frozen tuna in bulk from tuna purse seiners for Northwest Spain, discharging at the canneries as well as loading tuna in Tema (Ghana) for Puerto Rico. Seatrade also transported Greenland shrimp both to Denmark, Aalborg for the Royal Greenland Trade Department, and to Gloucester. also transported, according to van Overklift, potatoes and citrus from Egypt, seed potatoes from Netherlands to North Africa, butter and poultry. In the mid 1970 s, the fish trades accounted for about $50-60 \%$ of Seatrade's income.

\section{3}

\section{The Newbuilding Programme}

Seatrade began ordering newbuildings and took advantage of the Dutch investment premiums scheme for merchant shipping that were introduced in 1976 . The Oceanic, which was the last newbuilding ordered by the original partners of SKG was delivered in 1977. This ship was followed by the so-called ABC's (Atlantic, Baltic and Celtic), which were delivered to the Norwegian fish trade by the time fishing restrictions, due to overfishing, had destroyed the large-scale 
westbound cod business in the North Atlantic around 1980. They were later lengthened and employed in other fish trades. The ABC's were followed by the Arctic class of $130000 \mathrm{cbf}$, later lengthened to $185 \mathrm{ooo}$. The old vessels from the 1960 s that still remained in the fleet were disposed of and replaced by these newer and larger ones. Although the size of the vessels ordered gradually increases over time, it is still apparent that Seatrade at this time is maintaining its focus on small vessels servicing the fish trade. Alongside with the ordering of newbuildings, Seatrade started to engage in the sale and purchase of second-hand vessels. It is often stated that it is in this field that the greatest profits are to be made and Seatrade has increasingly since the 1980 s been an active player in this market.

Seatrade had employed several shipyards for its newbuildings. These were usually local shipyards in Groningen including Nieuwe Noord Nederlandsche Scheepswerven. Another was Scheepswerven v/h Gebr. Van Diepen in Waterhuizen, just outside of Groningen on the Winschoterdiep canal. Before looking at development of the N-type and the M-type that followed it is worthwhile to recall that Seatrade, at this time in the early 1980 s, still had much in common with the small company that five captain-owners formed thirty years earlier. Yes, it had specialised by focusing on reefers and it had grown both in size and ambition. However, it was still very much a Groningen company operating in a local milieu. The company was managed on a day to day basis by its three owners who were ship-owners themselves. Ships were built locally and a significant part of their investment came from established local investors, just as it had been for generations. Everyone could attend the christening of a new reefer; the shipyard was just a short trip way. Many of the crew onboard the ships called Groningen home. These things would change but it is in this context that the N-type was built.

The N-type, which was developed by Geert Pepping and Henk Schuur, was revolutionary, according to respondents at Seatrade. Marnix van Overklift describes them as "marking a shift in the company history". The ships were revolutionary to Seatrade not only in size but more so in efficiency. Not only were they generally larger than what the company had built previously with about $265000 \mathrm{cbf}$. Also, they were exceedingly "rational". They responded well to the new trends in the reefer markets, namely that bunker prices remained high after the oil shocks, and that perishables, as well as other cargo, were increasingly being transported on pallets. The N-types were designed to maximise their volume and could transport over 2400 pallets; and could do this with a small crew and in a vessel that was bunker-efficient by the standards that prevailed at the time. The reason that the $\mathrm{N}$-types could sail with small crew was related to a new shipping law that came into effect in 1983 whereby the size of 


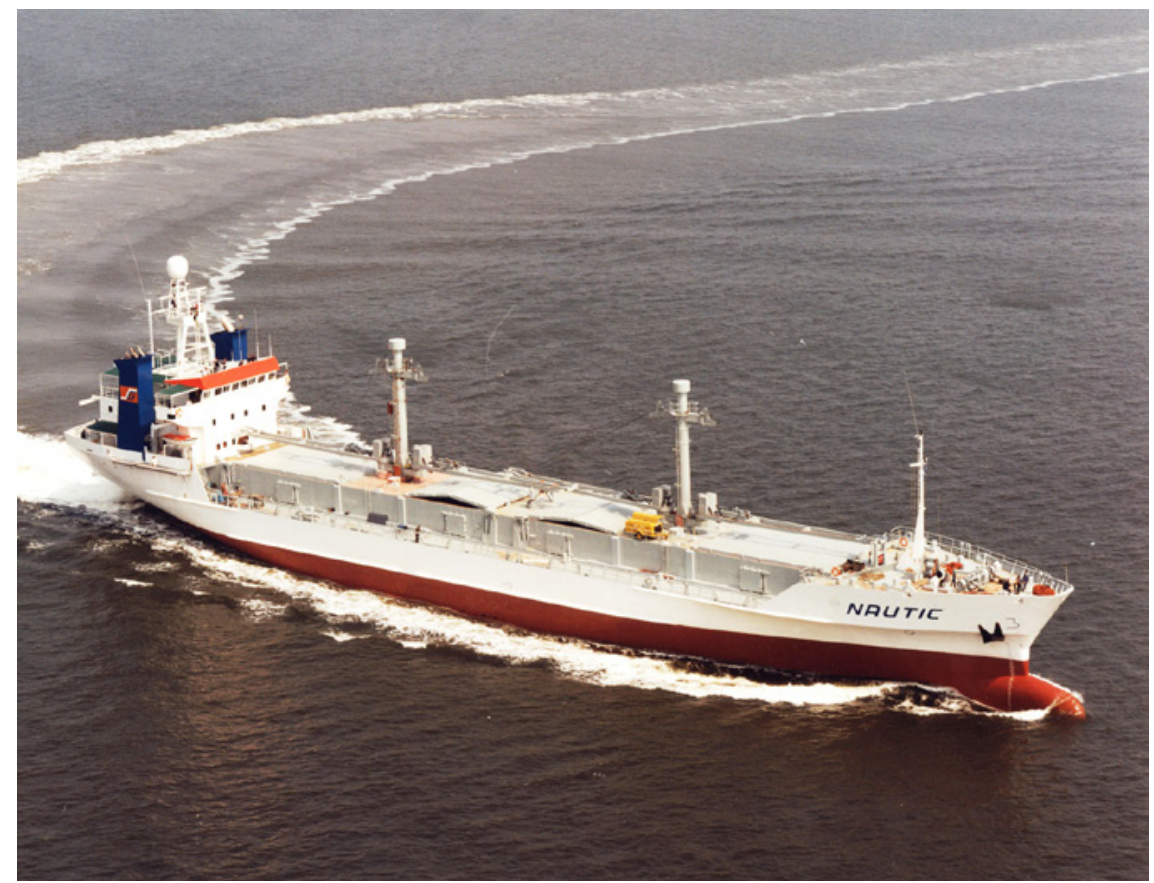

FIGURE 14 The Nautic was the first of the N-types, efficient locally-constructed vessels, and the start of a long newbuilding programme that eventually established Seatrade as major force in reefer shipping

PHOTO: SEATRADE

vessels that were categorised as "small" was increased to 4000 gross tons. This meant that the vessel didn't require a radio officer for instance and that the crew didn't require merchant marine documentation for deep sea trades. This meant that the new bigger ships could use the same crew that had sailed on Seatrade's other ships. These factors reduced operating expenses. This law also encouraged shipowners to lengthen their smaller vessels. In any case, the Ntypes were designed to exactly comply with the new regulations.

The first of these modern cost-effective vessels was the Nautic built in 1983 at the Gebr. Van Diepen shipyard. The management of Seatrade remember that the planning and discussions with the shipyard about these newbuildings were fairly informal. The owner of the Van Diepen shipyard regularly visited the Seatrade head office in Groningen on Fridays and discussed things over coffee. A disagreement on pricing led Seatrade to build the second of the N's "across the street" from Gebr. Van Diepen at Scheepswerf Pattje and this was the Normandic also in 1983. Over the next three years another five N's were built and a few years later another two that were slightly larger. Besides the 


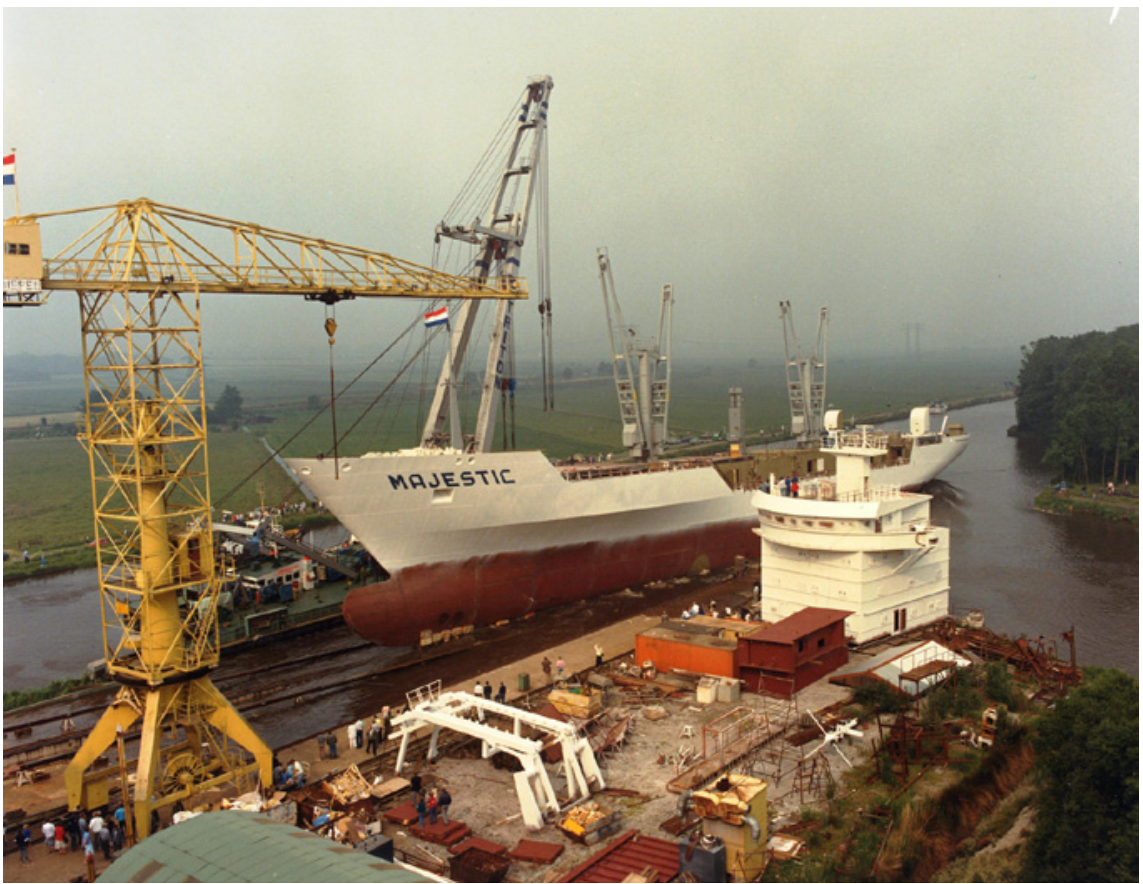

FIGURE 15 The M-types followed on from the N's, they were a little larger at 310 ooo cbft, and established a larger presence for Seatrade in the fruit trades PHOTO: SEATRADE.

Normandic, all these were built at Gebr. Van Diepen. These vessels were marketed as sister-ships but they actually differed slightly from one and another. They were ordered one at a time and as they were built Geert Pepping and Henk Schuur would inspect and plan for improvements to be incorporated on the next one. It must not be forgotten that Geert had a particular predilection for technical matters. The procedure was followed when the six larger ${ }^{6} \mathrm{M}$-type vessels were built at the same shipyard from 1988 to 1993. After a few more vessels the era of locally built reefers ended and Japan became the source of newbuildings.

To sum up, eigtheen state-of-the-art reefers were built in about ten years, including ships for Vroon and Van Diepen itself. Dutch investment premiums for shipping companies helped to finance the newbuilding programme. Seatrade as a company was the largest investor but, as mentioned, local families and investors were also involved. Stakes were also taken by other parties,

$6310000 \mathrm{cbf}$. 
including the shipyard and the agent in Gloucester. Favourable time-charters were obtained for many of these vessels which facilitated bank financing which had, as usual, also been taken.

Some of the new vessels, mainly the N's were partly used in the company's fish-trades, including the parcel-service from Argentina. They were, however, designed to carry palletised fruit and bananas and this meant expansion into the spot market for fruit trades. This included some banana business for Geest and Jamaica Producers, and also for the Italian fruit traders De Nadai and Orsero. Seatrade acquired additional know-how including contacts in the fruit business when Erik Musterd, an experienced charterer, joined the company in 1987. As with Geert Pepping, he came from their Dutch rival Dammers \& Van der Heide. The delivery of the N-types changed the transport patterns for Seatrade. Rather than fish standing for $50-60 \%$ as in the mid 1970 , around 1985 , proportionally it was around: $30 \%$ fish, $25 \%$ bananas, $25 \%$ other fruit, and $20 \%$ various.

The Nigerian fish importer Primlaks that had been an important Seatrade customer entered the reefer market in the mid 1970s. They purchased reefers originally through Jaczon and also general cargo ships that they converted to reefers. Their shipping operation, based in Rotterdam, faced financial difficulties after a few years so the banks requested that the vessels be placed under professional commercial management: half of their fleet of 16 vessels entered the Seatrade Pool in the mid-1980s. Seatrade had operated a pool since the late 1950s, but it was with the addition of the Primlaks vessels that the pool operation really kicked off. Other third party operators at the time include the major Dutch shipowner Vroon and the Dutch fishing concern Jaczon, each with a few vessels. Laskaridis-owned Lavinia was "in and out" of the pool. The number of vessels in the pool changed constantly, but in 1986/87 numbered around thirty vessels. Within a few years this figure would double. And later double again. The reason for ship-owners to enter the pool was to access competent and able commercial management team that could generate more income than they could if they operated the ships themselves.

The pool was split into what was appropriately called Pool 1 and Pool 2. Pool 1 consisted of the smaller vessels only doing fish-trades. Pool 2 consisted of the larger ones in mainly fruit trades. Seatrade, with newbuildings, fruit business and an expanding pool has by this stage grown into a medium-sized operator 


\begin{tabular}{lllll}
\hline Laskaridis & Columbia ship- & Thien \& & Green & Chiquita/GWF \\
& management & Heyenga & Reefers & \\
Roswell & Holy House & Zodiac & Salgaria & Fyffes \\
Anthony Veder & Leonhardt \& & Swedish Orient & F Laeisz & Ocean Link from \\
& Blumberg & Line & Schiffahrt & Oslo \\
Christian & Far East Shipping & Toei Shipping & Kyoei Kaiun & Lomar Shipping \\
Ahrenkiel & & & Kaisha & \\
Hamburg & & & Vroon & Jaczon \\
Drytank SA & Nissui Shipping & & & \\
& & & &
\end{tabular}

a Gorter, D. 2014. Nederlandse koopvaardijschepen in beeld - Seatrade, part 2, Alk B.V.

in the global reefer market. Another medium-sized operator was its Dutch arch-competitor in Rotterdam: Dammers \& van der Heide.

Dammers \& van der Heide's Shipping and Trading Company (Dammers) of Rotterdam was an important and respected player in the reefer industry until the death of its founder ${ }^{7}$. Seatrade's subsequent acquisition of Dammers in 1989 caused Seatrade to double in size. The story of Dammers' rise is a story worth telling for its own sake and its importance for Seatrade makes it doubly so. The two companies developed along similar lines, from a small coaster operation, to small reefers and then to larger reefers carrying fruit. In a sense it was Seatrade that followed in the other's footsteps: it was Dammers that always took the first step. However, despite some similarities, these were also two very different organisations. The story begins in 1945 .

Jan Dammers at the age of 35, with experience in shipbroking decided to go his own way when the Second World War ended. The company was founded together with Antonius Wilhelmus van der Heide on 1 September 1945 and started with two small coasters, one of them the Tijger, was owned by Hendrik

7 The part on Dammers is based on Gorter 2012. and Otten, J.M. 2005. Dammers \& van der Heide, Ridderkerk: JeMoTek, and Peerbolte 1991, and interviews with Seatrade management. 
Pepping. This was initially only a chartering and agency operation but soon ordered its own vessels. The Biscaya and the Casablanca, both coasters were delivered in $195^{\circ}$ and promptly and profitably sold to Indonesia in the following year. These were the boom years of coastal shipping and vessels were in short supply because of the war. However, 1951 was also the year that Van der Heide passed away. It was also the year that Hendrik Pepping came onboard as the Director of the technical department.

Four more vessels followed in 1951-52, including a replacement - Casablan$c a$-reflecting that a liner service to Morocco was an important trade for Dammers in the fifties. All of these vessels were built at Gusto Shipyard in Schiedam and were below the 500 grt limit to be classed as short sea shipping. One of these, the Fedala, was converted into a reefer in the mid-fifties when the company received a U.S. government contract to carry meat from Ireland to Rotterdam and from there by lorry to the armed forces stationed in Germany. Further conversions followed including the Tom van der Heide in 1957. In 1965 this was the first Dammers vessel to be placed on time-charter with Marine Chartering Co (MCC) of San Francisco. This began a longstanding business in West Africa and South America with frozen tuna on behalf of Refrigerated Express Service; Seatrade inherited the contract when Dammers was acquired.

Newbuilding intensified in the sixties as Dammers' vessels started sailing in American waters between New York and the Caribbean on behalf of American Chester, Blackburn \& Roder. Ten part-reefers were constructed as the "Atlantics" for Atlantic Lines. These vessels had one regular hold and another that carried frozen cargo. These vessels were also below the 500 grt limit and were built at Boele Bolnes and at Nieuwe Noord Nederlandshe Scheepswerven in Groningen. This was in the same period as Scheepvaartkantoor Groningen (later Seatrade) constructed its first reefer that, as mentioned previously, was chartered to Dammers. Fully refrigerated vessels were also constructed during this period and they were larger as well. The four Inca's were built at Gusto with $100000 \mathrm{cbf}$ and the slightly smaller Laura Christina's were built in France. Two of the former were built for a subsidiary of Anthony Veder of Rotterdam, later with vessels in the Seatrade pool. The end of the decade saw Dammers take on the management of three vessels 125-150 ooo cbf from a Kuwaiti fishing company and with this also came building contracts for vessels of $160000 \mathrm{cbf}$ ("EAseries"). There were other vessels built, purchased or chartered and vessels were also sold.

In 1972 Dammers \& van der Heide became a serious player in the fruit business by buying Belgian Fruit Lines (B FL), which owned six reefers at slightly over 300 ooo cbf. The vessels, known as the "Frubel-types" (for Fruit Belgium) had been sailing in the fruit trades, particularly bananas from Ecuador. Dammers 
actually only bought three of the vessels; KNSM (later a part of Nedlloyd) took the other three but all the vessels sailed with Dammers. These vessels were involved in many fruit trades, not just bananas, apples from New Zealand for example. Most of these vessels were sold about five years later when Standard Fruit (later Dole) decided to re-establish itself as a shipping company. This was the start of the relationship that developed between Dammers and Dole. Dammers also developed a strong business relationship with Chiquita.

Hendrik Pepping had retired in 1973 but remained a shipowner until just prior to passing when he handed them over to his three sons. One of his sons was Geert Pepping who had worked in Dammers' chartering departments in Monaco and Rotterdam. When Geert left to Seatrade in 1977 he took the Pepping vessels with him, thus breaking the Pepping family's long connection with Dammers - until Seatrade took it over in 1989.

Dammers \& van der Heide had by the mid-seventies sold most of its small vessels though a few would remain in the fleet until the early eighties. The company became more focused as a reefer operator but it had developed a fairly diverse portfolio. It managed a couple of tankers for the Shah of Persia, a bulker, a ro-ro, and the Giant, a heavy lift ship. Dammers also had a liner shipping agency, a travel agency and were the European agent for the Columbian and Venezuelan national lines. It had taken Jan Dammers about twenty years to build a solid and respected Rotterdam shipping company, and he had started from scratch.

The focus on reefers solidified when the Netherlands began the shipping investment premiums in 1976. Dammers immediately ordered eight 130000 cbf reefers from Nieuwe Noord Nederlandse Scheepswerven in Groningen and they were delivered between 1977 and 1980 and lengthened to a 181 ooo cbf capacity in 1983. The first of the class was the Jan Willem, named after Jan Dammers' only son who had passed away in 1965 .

Even more ambitious was the programme to build new large vessels to replace the older Frubels that had mainly been sold to Standard Fruit (Dole). The result was the Honolulu's that were fixed on time-charter with Dole. These vessels were "full-size" fruit carriers at over $530000 \mathrm{cbf}$ and were built at the Van der Giessen-de Noord shipyard. The initial four, the Honolulu, Lanai, Rio Frio and Christina were delivered in 1979-80. Two more, the Tineke (named after Jan Dammer's daughter) and the Peggy Dow, were delivered in 1984 and 1985. In 1985 Dammers also purchased three of the Spring vessels from the estate of the bankrupt Swedish Salén. Seatrade at the time showed no interest in these vessels, they were still focused on the smaller size.

Meanwhile the first four of the Honolulu's had been handed back to Dammers by Dole. One problem with these vessels was that they were not ideally 
suited to palletised cargo, lacking squaremeter deckspace. There had also been friction between the two parties over the type of bunker fuel used. The vessels had been designed to be able to operate on a heavier (and thus cheaper) grade, something that Jan Dammers refused to allow for the auxiliary engines. He wanted to protect his investment but Dole was unhappy about the additional expense. Jan Dammers presented a long list of damage claims when the charter was completed and the vessels returned. What constituted reasonable wear and tear? The situation was bad enough to cause Dole and Dammers to separate for a few years before they got back together again. The immediate problem for Dammers was what to do with the newly purchased Spring vessels. The simplest and most expedient solution was chosen. They sailed with Cool Carriers for a few years on time-charter. When Dole and Dammers patched it up they were usually sailing for Dole. The Central America-Wilmington-Newark service is an example of one of the trades that the Spring's sailed on. In 1988 Dammers and Dole set up a joint pool but in that same year Jan Dammers died at the age of 77 and the family decided to put the company up for sale. Dale Ploughman was put in charge of the commercial operation and the Dammers/ Dole pool continued after the sale.

Jan Dammers had indicated to his family before his passing that if it ever should come to pass and the company had to be sold then: "Sell it to the Dutch!" It may very well be hearsay, but it's also claimed that he added: "And preferably not to Seatrade!" There were few options however and key people at Seatrade were ex-Dammers. Besides Geert Pepping there was also Erik Musterd, a charterer and later director, who had left Dammers for Seatrade in 1987 . Vroon was the only major Dutch shipping company, beside Seatrade, with significant interests in reefers but nothing eventuated. Swedish Cool Carriers were also interested. Swedish sources say that a hurdle to acquiring Dammers was that the vessels built with Dutch subsidies would be prohibitively expensive due to the conditions that were attached to them in the event of a sale to a non-Dutch concern. Seatrade management remark that there would have been no difficulty for Cool Carriers to set up a Dutch subsidiary and that the issue simply boils down to Dammers' wish to keep it in Dutch hands. The subjective perception and values of the owner thus had a clear impact on the development of the business.

The acquisition of Dammers \& van der Heide in 1989 implied that Seatrade doubled in size, both in terms of tonnage and personnel. A growing medium-sized 
reefer operator was transformed into one of the market leaders. In terms of the number of vessels, Seatrade entered the nineties with the world's second largest reefer fleet, after Cool Carriers. In terms of capacity Seatrade was third, the discrepancy due to the continued presence of many smaller vessels serving the fish trades. Nevertheless, the major implication of the Dammers acquisition, besides growing in sheer size, was Seatrade's expansion into the fruit trades. Doubling in size virtually overnight is of course no simple thing. In this section we'll look at how the integration of the company took place and in doing so we can actually learn quite a bit about not only Seatrade but Dammers as well.

After the acquisition it didn't take long before Seatrade closed the Dammers head office in Rotterdam and combined the operations in Groningen. The Rotterdam staff was given the chance to follow with the move. Seatrade had just recently moved to new premises, the "Ice Cube" building, alongside the Hoornsediep canal, and could handle the influx of ex-Dammers personnel. However, only about a third, around twenty, made the move. Yntze Buitenwerf, present day CEO of Seatrade in Antwerp, explains that it was a big step for many people to move from the cosmopolitan city of Rotterdam to a regional, semi-rural place like Groningen. Some of the ex-Dammers employees moved to Groningen, some commuted from Rotterdam. After a few years only a few remained.

Mark Jansen is the Managing Director of Seatrade Holding in Groningen and also has a background in Dammers as a seafarer, is well placed to compare the two organisations. He says that the culture of the companies was completely different and adds that Seatrade was more creative, in finding backhaul cargoes for instance, while Dammers was more traditional in its approach. Both Seatrade and Dammers developed out of the old dry-cargo coaster trade and into reefers but they did so in different ways. Seatrade maintained its "small-shipping" traditions and only gradually expanded the size of their vessels along with their ambitions. The image that comes to mind is that of a small ship where everyone including the captain pitches in to do whatever needs to be done. Walter Wildöer at Seatrade means that this culture results in a flexible and "hands-on" organisation that is flatter in its structure and where people can make and are expected to make fast decisions. Dammers on the other hand made a rapid leap into the larger vessels of the fruit-trades and took on the "big-shipping" style with a more formal hierarchy. Walter adds that with Jan Dammers at the helm it could be in no other way.

Jan Dammers has been variously described as "headstrong", "charming", a "streetfighter" and as running a "one-man-show". In any case, decisions were made at the top. Mark Jansen says that it wasn't easy for everyone that went from Dammers to Seatrade to adapt to a completely different way of doing things. We can perhaps consider it to be some sort of cultural collision. These 
differences were not just restricted to the office. When Dammers built larger vessels (like the Honolulu's) senior crew were recruited from traditional major shipping companies like Nedlloyd (who were laying off at the time). Mark Jansen means that this brought along a more traditional old fashioned or formal hierarchy onboard. Furthermore, he adds that a hierarchy existed between the vessels, with greater prestige attached to the larger ones.

Seatrade's integration of Dammers was not without its problems due to all of these differences. There certainly were disagreements and the fact remains that only a small number of Dammers employees remained. A word that recurs when listening to the management of Seatrade is "control". By purchasing Dammers \& van der Heide they gained vessels, in particular larger but also smaller, they gained markets but they also took control and quite rapidly ensured that things were done in their way. The M-types, however, were being delivered as these events were taking place. The M's were modern mediumsized reefers designed for palletised trades and as newbuildings were partly backed with time-charters. The vessels from Dammers were employed with Dole and this relationship continued and was managed at Seatrade's end by Hans Rodenburg. Dale Ploughman at Dammers did not join Seatrade, however. He left to become Head of Shipping at Chiquita's Great White Fleet but knew people at the newly expanded Seatrade operation which led to business between Seatrade and Chiquita. Seatrade had no shortfall of know-how in the fruit trades but they were expanding, and their preference for liner trades (combined with spot) rather than time-chartering vessels out to a third party, required more hands-on involvement. This can again be linked to the idea of control, in this case controlling one's own vessels. Anyway, Seatrade were on the lookout for people with expertise with the fruit trades and four people from Sweden joined a couple of years later, something that will be detailed below. Meanwhile, with Dammers integrated, it was time to restructure the company.

TABLE 11 Fleet in the Pool and/or Managed by Seatrade in $1991^{\mathrm{a}}$

\begin{tabular}{llll}
\hline Name & Built & Cbf & Comment \\
\hline Oceanic Ice & 1977 & 126440 & Built as Oceanic \\
Atlantic Ice & 1979 & 134120 & Built as Atlantic. Lengthened in 1981 \\
Baltic Ice & 1979 & 134120 & Built as Baltic. Lengthened in 1981 \\
Celtic Ice & 1979 & 134120 & Built as Celtic. Lengthened in 1981 \\
Dakota & 1977 & 181 ooo & Built as Jan Willem. Lengthened in 1983
\end{tabular}


TABLE 11 Fleet in the Pool and/or Managed by Seatrade in 1991 (cont.)

\begin{tabular}{|c|c|c|c|}
\hline Name & Built & Cbf & Comment \\
\hline Swalan & 1978 & 181000 & $\begin{array}{l}\text { Built as Laura Christina. Lengthened in } \\
1983\end{array}$ \\
\hline Inca & 1978 & 181000 & Lengthened in 1983 \\
\hline Maya & 1978 & 181000 & Lengthened in 1983 \\
\hline Calafia & 1979 & 181000 & Lengthened in 1983 \\
\hline Magdalena & 1979 & 181000 & Lengthened in 1983 \\
\hline Mathilda & 1979 & 181000 & Lengthened in 1983 \\
\hline Casablanca & 1980 & 181000 & Lengthened in 1983 \\
\hline Pacific Tulip & 1977 & 193599 & Lengthened/rebuilt into reefer $1983 / 84$ \\
\hline Pacific Violet & 1978 & 194305 & Lengthened/rebuilt into reefer $1983 / 84$ \\
\hline Pacific Lily & 1978 & 195047 & Lengthened/rebuilt into reefer $1983 / 84$ \\
\hline Pacific Freesia & 1978 & 195047 & Lengthened/rebuilt into reefer $1983 / 84$ \\
\hline Pacific Rose & 1979 & 195047 & Lengthened/rebuilt into reefer $1983 / 84$ \\
\hline Pacific Queen & 1978 & 177988 & Lengthened in 1983 \\
\hline Pacific Marchioness & 1978 & 177305 & Built as Klipper II \\
\hline Pacific Princess & 1979 & 204166 & Lengthened in 1983 \\
\hline Honolulu & 1979 & 533845 & \\
\hline Rio Frio & 1980 & 533845 & \\
\hline Tineke & 1984 & 538667 & \\
\hline Peggy Dow & 1985 & 538667 & \\
\hline Antarctic & 1982 & 185739 & Built as Ena Maru \\
\hline Arctic & 1983 & 187535 & Built as Sapporu Maru \\
\hline Adriatic & 1984 & 182510 & Built as White Reefer \\
\hline Asiatic & 1986 & 191810 & Built as Sanuki Reefer \\
\hline Nautic & 1983 & 265245 & N-Type \\
\hline Normandic & 1983 & 265245 & N-Type \\
\hline Nyantic & 1984 & 265245 & N-Type \\
\hline Nordic & 1984 & 265245 & N-Type \\
\hline Neerlandic & 1985 & 265245 & N-Type \\
\hline Nayadic & 1986 & 265245 & N-Type \\
\hline Northern Express & 1986 & 265245 & N-Type \\
\hline Neptunic & 1989 & 273713 & N-Type \\
\hline Northern Explorer & 1991 & 273713 & N-Type \\
\hline Mystic & 1988 & 310394 & M-Type \\
\hline Majestic & 1988 & 310394 & M-Type \\
\hline Magic & 1990 & 310394 & M-Type \\
\hline
\end{tabular}


TABLE 11 Fleet in the Pool and/or Managed by Seatrade in 1991 (cont.)

\begin{tabular}{|c|c|c|c|}
\hline Name & Built & Cbf & Comment \\
\hline Music & 1990 & 310394 & M-Type \\
\hline Magnific & 1992 & 310394 & M-Type, under construction \\
\hline Maveric & 1993 & 310394 & M-Type, under construction \\
\hline Nidaros & 1985 & 163200 & Built as Olavur Gregersen \\
\hline Tinganes & 1985 & 163200 & Built as Svanur \\
\hline Cape Finisterre & 1990 & 300124 & \\
\hline Cape Cod & 1990 & 300124 & \\
\hline Cape Vincente & 1991 & 300124 & \\
\hline Cape Cavo & 1991 & 300124 & \\
\hline Cold Express & 1979 & 184118 & Lengthened in 1983 \\
\hline Ice Express & 1979 & 184118 & Lengthened in 1983 \\
\hline Spring Tiger & 1984 & 470494 & Built as Spring Breeze \\
\hline Spring Bear & 1984 & 466871 & Built as Spring Dream \\
\hline Spring Panda & 1984 & 461816 & Built as Spring Ballad \\
\hline Spring Bob & 1984 & 460895 & Built as Spring Blossom \\
\hline Schoener & 1991 & $45^{2} 816$ & \\
\hline Royal Klipper & 1987 & 261262 & \\
\hline Orange Klipper & 1991 & 263300 & \\
\hline Oceaan Klipper & 1992 & 263300 & Under construction \\
\hline Nova Scotia & 1983 & 263097 & Built as Hokusei Maru \\
\hline Nova Zembla & 1986 & 239258 & Built as Aoshima Maru \\
\hline Nova Liguria & 1985 & 230384 & Built as Ligurian Universal \\
\hline Nova Terra & 1985 & 230014 & Built as Adriatic Universal \\
\hline Nova Klipper & 1992 & 270189 & Under construction \\
\hline Prins Willem Van Oranje & 1987 & 350852 & \\
\hline Prins Casimir & 1988 & $35445^{2}$ & \\
\hline Prins Frederik Willem & 1990 & $35445^{2}$ & \\
\hline Iglo Express & 1979 & 220384 & $\begin{array}{l}\text { Built as Guadeloupe. Lengthened in } \\
1983\end{array}$ \\
\hline Joint Frost & 1979 & 139335 & \\
\hline Fenland & 1979 & 112706 & $\begin{array}{l}\text { Built as Boston Sea Lance. Lengthened } \\
\text { in } 1985\end{array}$ \\
\hline Nickerie & 1985 & 190525 & \\
\hline
\end{tabular}

a Peerbolte 1991, p. 76-78. 
The global capacity of conventional reefer vessels reached its maximum in 1993 as a result of the massive newbuilding of larger reefers in the eighties and early nineties. The market struggled with oversupply as a consequence of this and Seatrade faced additional competition in the frozen-fish segment by the influx of vessels from the former Eastern Bloc. Rates were low and as a consequence the next years saw a necessary but probably inadequate increase in scrapping. Seatrade's fleet was modern however, and the plan in the face of a sluggish market was to both continue in its expansion and to improve profitability. Seatrade moved its chartering department to Antwerp, a move that was driven by tax incentives, but also put the operation in a place where it was easier to attract qualified personnel ${ }^{8}$.

Shipmanagement, the technical side, remained in Groningen and Tom Tammes, one of the owners, remained there for over a year before retiring. Tom Tammes was not too interested in moving to Antwerp, and he had two daughters, who were not interested in carrying on the business. This led to Tammes selling his shares to Marnix and Geert in November 1989. Henk Schuur had sold his shares earlier. Commercial management, including the shipping pool, moved to Antwerp 9 and the name of the operation was temporarily changed to Scaldis Reefer Chartering ${ }^{10}$, again for tax reasons, it reverted to the Seatrade brand as Seatrade Reefer Chartering in 1998. The move entailed that many of Seatrade's personnel moved to Antwerp; the operation was headed up by Erik Musterd. The company's working language in the office was changed from Dutch to English due the various nationalities working within the increasingly internationalised organisation.

An additional benefit to moving the chartering operation to Antwerp was that the company gained a physical proximity to some of its shipping operations. This connection between chartering and the actual vessels had been close in the early years of the company, but was fading. A remaining vestige of this connection was about to disappear with the delivery of the last newbuildings from Groningen. The move to Antwerp changed all this. Reefers coming in to port can be seen through the windows of Seatrade's present day Antwerp office in Atlantic House. A major cold-storage facility is literally across the

8 Tonnage tax was related to this and means that the income of the ships is calculated based on the gross tonnage of the ships. Companies are taxed based on this income rather than on the real income of the ships.

9 The Antwerp operation was formally a subsidiary of a newly established parent company in Curacao.

10 Antwerp lies on the banks of the river Scheldt, in Latin: Scaldis. 
road. Seatrade likes to market itself as a "hands-on" company and the location in the port of Antwerp is advantageous. It's a simple matter for people from the office to speak with captains and to see the vessels. And if Seatrade's customers are visiting, they can be given a tour if a Seatrade vessel is in port at the time. Consequently Seatrade personnel explain that they try to keep their vessels freshly painted and generally looking good. It can also be maintained that the Antwerp location may have the intangible benefit of connecting head office personnel, empathically, to the vessels, crew and cargo. Sources within the industry have contrasted Seatrade's location with Cool Carriers' location in Stockholm where the head office is physically remote from the nuts and bolts of shipping.

Seatrade's shipbuilding also moved away from the local Groningen cluster. Contacts were established in Japan which was an important market and also an attractive place to build the next generation of reefers. When Seatrade first started to build at Kitanihon shipyard, they had a trading house as intermediary between them and the shipyard. When Seatrade wanted to make changes in ship design during the building process, the trading house said that such changes were not part of the deal. Later on Seatrade turned to their Japanese partner East-West Navigation. The company's founder Mr Ikeda dealt directly with the yards and became Seatrade's sales \& purchase broker in Japan. But East-West also supplied commercial connections. Marnix explains:

East West was established by Ikeda who had left Nissui to explore new opportunities. He had good relations with both Seatrade and Laskaridis and considered becoming an agent for one of those companies. Eventually, he set up East West as an independent organization that was particularly associated with Seatrade.

Van Overklift actually coined the name which reflected the link between Eastern and Western markets. Marnix explains that from Seatrade's perspective East-West had a wide network of contacts in the reefer business, for example the fish trades from Alaska, North Pacific and South Atlantic. Furthermore, they were well connected with banana trades from the Philippines to Japan, Korea and the Russian Far East. Seatrade started to fix ships through East West, and gained contacts with Korean shipping companies and the Far East Shipping Company, FESCO. Another outcome was that since 1997, Seatrade started to source Russian crew from Vladivostok.

Seatrade was also able to attract commercial know-how from the market leading Cool Carriers. The Swedish Salén was for years the global leader in refrigerated shipping. It dominated the prestigious fruit segment of the market. 
The Salén bankruptcy in 1984 and its phoenix-like resurrection as Cool Carriers was commercially successful but was followed by ownership problems which left several of its employees disillusioned. Four of them, Lars-Gunnar Larsson, Thorsten Klenell, Gösta Norén and Peter Jedeur-Palmgren, saw an opportunity to break out and start their own operation, with the support of Seatrade. Their departure was seen as a breach of loyalty at Cool Carriers, but Lars-Gunnar Larsson points out that their loyalty was to Salén and that this had been eroded by the developments of Cool Carriers.

The "four" founded Scanreefer Chartering in Stockholm and, and because of their extensive experience, managed to attract new business. One of the managers recalls that Seatrade had an ambition to grow and says that he believes that they played an important part in achieving this. Together they owned $40 \%$ of the new company; the remaining $60 \%$ belonged to Seatrade. Each of the four brought particular chartering specialisations: Lars-Gunnar Larsson with Australia and New Zealand, Thorsten Klenell with Argentina, Gösta Norén with the citrus trade as well as Israel and Chile and Peter Jedeur-Palmgren with the spot market as well as Turkey and South Africa. They also recruited Lars Nilsson, formerly Cool Carriers Maritima in South America, to head up Seatrade's new representative office in Argentina - Navisur in 1993. Bror Bjurström in Australia also moved over to Seatrade.

Scanreefer was attempting to break into new trades, for example citrus from Argentina and meat from Australia to the us East Coast, and one aspect of doing this was to offer highly competitive pricing. One outcome of these events was that a good portion of Seatrade's fleet of larger vessels was put to work in the citrus trades during off season. According to Seatrade's management, the access to the off-season citrus trade was necessary to ensure that Seatrade's growing modern fleet could be employed throughout the year. However, there were reasons for combining the operations. It was difficult to coordinate parallel organisations doing things in different ways and located in different countries. Walter Wildöer sums up the problem as "too many cooks" and adds that the solution to buy out Scanreefer "comes back to the genes of the company, it comes back to control". Scanreefer's existence thus ended a little over a year after its inception when Seatrade bought out the Swedes and merged the operation into their own. The four Swedes moved to Antwerp and Lars-Gunnar Larsson became General Manager of Seatrade Antwerp.

These newly developed fruit trades required a higher service commitment from Seatrade so local representative offices were established to make the trades work. Since then many more offices have opened so that in 2014 they were twenty-five in total. Seatrade ventured into cold storage facilities in Argentina in 1995 to mainly support the fruit trades. Old sheds were bought 
and converted in Rosario, Concepcion del Uruguay, Bahia Blanco and Puerto Deseado in the far south for fish. Seatrade exited the entire operation only five years later due to industrial conflicts and lack of profitability.

\section{In the Turbulent Market of the New Millennium}

The years around 2000 were characterised by many attempts at consolidation between the players in the market. Also, the low rates that prevailed within the reefer segment, primarily as a result of competition from the container lines, made life increasingly difficult for many. Seatrade was frequently the buyer when others wanted to sell. Tentative discussions were held with Lauritzen, Cool Carriers and Star but nothing eventuated. Lauritzen ended up buying Cool Carriers and later exited by selling to NYK. Seatrade were disappointed to miss out on purchasing the bankrupt Swan Reefers of Norway, which was acquired by Siem who later acquired Star. However, Seatrade successfully acquired a part of Nissui's reefer operation in 2001, which resulted in the formation of Tokyo Reefer Chartering. The purchase also included new business for Seatrade: carrying squid and krill from the South Pacific to the Far East and Europe. Tokyo Reefer Chartering was later integrated into Seatrade's pool and East-West Navigation.

Another significant deal for Seatrade was when Vroon's United Reefers was bought. Vroon of Breskens is a major Dutch family-owned shipping company, founded in 1890, that is highly active in several areas of shipping including livestock transport, offshore support and dry cargo. In the seventies they diversified into the reefer segment by purchasing a few vessels that were put into the Seatrade pool around 1980 . More vessels were obtained in the nineties and finally in 2001, after some 20 years in the Seatrade pool, Vroon decided to take control over their reefer fleet and established United Reefers as an independent operation. Vessels owned by third-parties joined the United Reefer fleet so that by 2005 there were 22 vessels when Vroon decided to exit the reefer segment. Seatrade bought United Reefers including Vroon's reefers. Most of the third-party owners joined the Seatrade pool. The relationship with Vroon dated back to $195^{2}$ when Vroon bought its first cargo ship, the David, which was managed for some time by Scheepvaartkantoor Groningen with Schuur as partner in the ship.

At this time, the shipping markets were good and the German Kommanditgesellschaft (KG's) were keen on finding investment opportunities. In 2005 and 2006 Seatrade sold 28 vessels to MPC Münchmeyer Petersen Steamship based in Hamburg. Seatrade maintained a minor level of ownership in the 
vessels which continued to sail in the Seatrade pool. The market value of the vessels was high, due to the good market. A consequence of the sale to the German KG house was the purchase of Triton, a shipmanagement company. A requirement of the KG operation is to have a fully-fledged outfit on German soil. This was developed as a parallel shipmanagement to the operation in Groningen and is located in Leer, close to the Dutch border.

This period of expansion also coincided with Geert Pepping's plans to retire. Marnix explains:

After having bought in 2006 the majority of the shares of my partner Pepping, he withdrew from daily activities, however he remained as a shareholder and boardmember, being fully aware of the company whereabouts, though he remained in the background.

Twelve smaller vessels were also sold to Norwegian Green Reefers of Bergen in 2006 in exchange for cash and $25 \%$ of the shares ${ }^{11}$. Seatrade purchased five Phoenix class vessels from London-based Zodiac Maritime in 2007. Zodiac, part of the Israeli Ofer group, is a major shipping operation that diversified into reefers by purchasing Honolulu class vessels from Seatrade and vessels from NYK. They were active for several years before deciding to exit. Also in 2007, Seatrade purchased the reefer business of Maritima del Norte, an independent Spanish operator. This added seven smaller reefers to Seatrade's fleet and these were put to work in the frozen fish, mainly tuna, trade. Furthermore, Seatrade bought a part of Amer Reefers' fleet in 2008.

In 2007 four new reefers were ordered at the Kitanihon Shipyard, and until summer 2008 another four had been added to the order.

Seatrade purchased the operations of the bankrupt Europe West Indies Line (EWL) in 2008. There were no vessels involved but it was a container operation and according to Yntze Buitenwerf, it brought a new focus on containers into the company. Seatrade incorporated EWL into its container division which is marketed as StreamLines. StreamLines is focused on the reefer trade and may be considered an integrated, but somewhat detached, part of Seatrade. StreamLines also operate container vessels.

Due to the collapse of the financial and shipping markets in the wake of the 2007-2008 crisis, it was clear in 2009 that Seatrade wanted to reduce the number of ships on order at the Kitanihon shipyard. Eventually the Atlantic Klipper and Baltic Klipper materialized from the order and these two were fixed to Russian Joint Fruit Co in 2010 for a period timecharter.

"Zodiac sells off stack of reefers", TradeWinds 10 May 2007. 
The aforementioned sale and lease-back of ships to MPC included a guaranteed minimum earning for the ships. Tradewinds wrote that: "Seatrade is also guaranteeing a minimum income of $\$ 0.78$ per cbf per ship if charter rates fall over the next 5 years."12 The charter rates did fall, but a spare fund had been created to cope with this market risk, and according to Van Overklift, it was sufficient to cover the deficit that emerged.

What caused the most significant problems was the takeover of the Amer Reefer fleet in 2008. Marnix explains that not all of these ships were supposed to be owned by Seatrade, but by poolpartners and other investors. However, given the financial crisis, the prospective owners could not fulfil their commitments. The financial crisis of course also affected the supply of debt funding. ING, the house bank of Seatrade, got into trouble and had to be bailed out by the Dutch Government. This caused problems for Seatrade, as explained by Marnix:

We received a short loan from a consortium of banks, lead by ING Bank, the loan had to be renewed or paid back after one year. Although Seatrade had been their customer for 35 years and never failed on any commitment, the bank refused at the very last moment to renew the loan, not even willing to give us any time for a solution. A solution had to be found and I decided to sell my shares to my old partner to solve the liquidity problem. My old partner made a deal with the bank and got involved again in running the company. This ended a 32 year old cooperation and relationship but I also had to say goodbye to loyal people and friends in the organisation and on board of the ships, who made it possible to create such a great company.

Now Geert Pepping was back as the main owner of Seatrade and the company continued to develop.

\section{New Partnerships: GreenSea Chartering and Joint Ventures}

A new pool called Hamburg Reefer Chartering was established in 2010 by Seatrade, Laskaridis and Green Reefers. Seatrade already had an established relationship with Green Reefers. Green Reefer's originator, Nomadic Shipping, entered reefers in 1989, and placed a reefer in the Seatrade pool. In 1993, they created their own pool called Green Reefers. Seatrade perceived Green as a

"Seatrade charter term questioned". TradeWinds 1 March 2007. 
fierce competitor particularly in the fish segment. Seatrade sought to collaborate and eventually established a joint service from Florida to Flushing with frozen juice. A joint pool operation was created around 1997, each party bringing 12 ships of about $260000 \mathrm{cbf}$. It worked for less than a year and then Eidesvik, Green's new owner cancelled the agreement.

Lavinia with its Alpha Reefer pool, controlled by the Laskaridis family, was a large company that also competed with Seatrade in the fish segment. Lavinia has at various times placed their larger vessels in the Seatrade pool and the two companies had also coordinated their purchases of ships from distressed shipowners.

Hamburg Reefer Chartering did not last long and ceased at the end of 2011. Yntze Buitenwerf says that in this industry "nobody trusts each other" and that a problem with Hamburg Reefer Chartering was that both parties wanted one of their own people to be "the real boss". The result was that this attempt at consolidation was discontinued and Seatrade and Green Reefers pulled out of the operation and formed GreenSea Chartering. Lavinia's larger ships that sailed in the Seatrade pool were was also subsequently removed.

GreenSea is based in Antwerp close to Seatrade's offices and operates the two companies' vessels with a capacity between 190000 and $400000 \mathrm{cbf}$. It mainly deals with fish and seafood. There were about 38 vessels in the pool in 2017. Tuna companies are frequently charterers and the major trades are with fish from Northern Europe to ports in West Africa and then returning with tuna from Abidjan. Tuna in the Indian Ocean to Bangkok is another important trade.

An alliance with St Petersburg-based Baltic Shipping was established in 2013 and appropriately named Reefer Alliance. Reefer Alliance is a sales and marketing operation with coordinated scheduling. Three trades were included in the arrangement and they link Chile, Morocco and South Africa with St Petersburg. The main cargo was citrus and deciduous fruit. Later in the same year a new company came to being: Global Reefers. This was a joint operation with Pacific Seaways, a shipping company that represents major Chilean fruit exporters. They were major users of reefer tonnage and the new operation can be seen as an effort to ensure the availability of vessels and cargo for the respective parties.

The backdrop to all of these joint ventures was a market with both shrinking demand and shrinking numbers of specialized reefers. Exporters who were using these vessels wanted to ensure their continued availability. Operators, on the other hand, sought to maintain their customer base and to optimise their operations by coordinating their efforts with their competitors to the extent that is possible. 
An unusual venture eventuated in Australia where Cool Carriers and Seatrade were competing in the meat trade. The cutthroat competition from the container lines resulted in the arch competitors burying the hatchet and opening the joint-venture $C \& S$ headed by Bror Bjurström which existed until the container lines completely took over the trade in 2008.

\section{6o Quality}

The 360 Quality initiative was born in 2005 when LauritzenCool, Seatrade and NYK Reefer decided to collaborate on quality issues with diverse actors within the cold chain. It was primarily a joint reaction to the increasing competition from the container lines. 360 Quality aimed to both improve quality in the operations and to jointly market the logistical alternative provided by specialized reefers as a high-quality option.

Seatrade was gradually adapting to containerization, as evidenced by its acquisition of EWL in 2008 and its conversion of two reefers in 2012. The ships were cut in half and a section was added which tripled the number of containers that could be carried ${ }^{13}$.

2014 was the year that Seatrade ordered its first two reefer-container vessels and this was followed by orders for a further four with options for a further six. Delivery commenced in 2016 with the Seatrade Orange, which was timechartered to Africa Express Line. These vessels, the Colour Class, were built in Shanghai by the Yangfan Group ${ }^{14}$.

For decades reefer operators had defined themselves in contrast to the major container lines, and now Seatrade ordered container ships. A radical step? Mark Jansen, managing director of Seatrade Holding points out that there is a natural progression in the development of reefer vessels. From breakbulk to palletised to palletised with container capacity and now to fully containerised. With, hindsight, we can call the previous type, many were built in Japan in the late nineties, a hybrid vessel and thus a stage in the development to what is happening now. Another aspect is that fruit companies, particularly Dole, have

13 "Carriers put money on hybrid designs". The Journal of Commerce, 2012-11-16. <http:// www.joc.com/maritime-news/ships-shipbuilding/carriers-put-money-hybrid-ship-de signs_20121116.html>. 


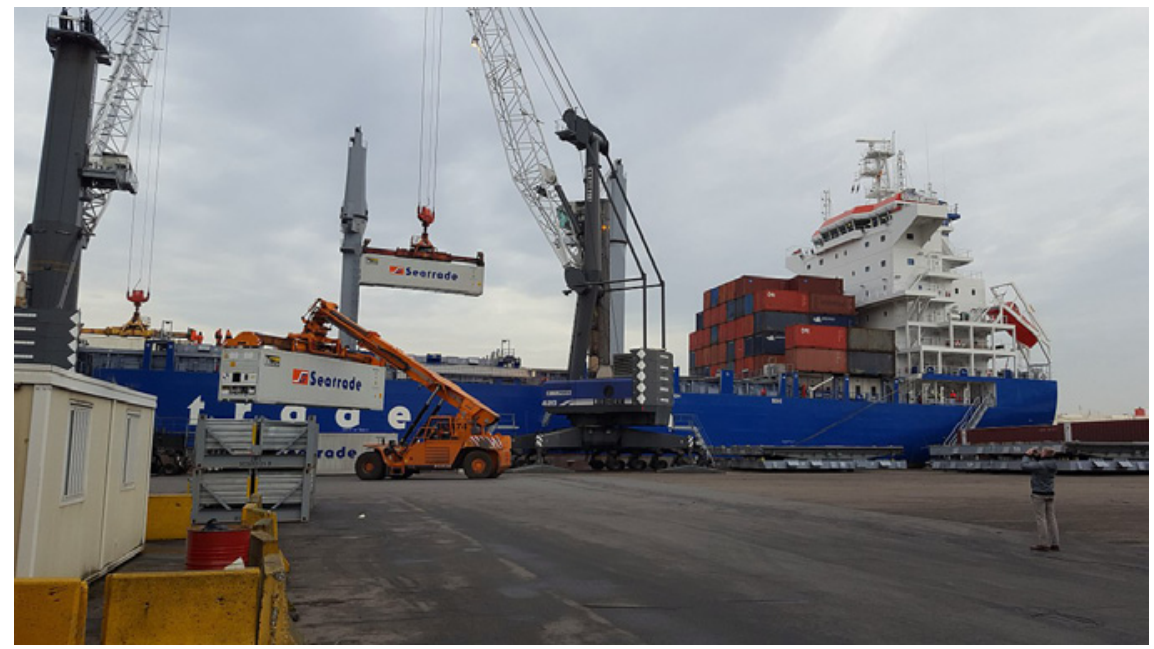

FIGURE 16 Seatrade was the first independent reefer operator to build reefer container ships, starting with the Seatrade Orange in 2016

PHOTO: SEATRADEGRONINGEN

previously built similar vessels. The modern type has the cooling and ventilation necessary to be able to stow reefer-containers below deck. 100\% containerisation aside, the ships otherwise have much in common with previous reefers. They utilise their speed, they can access and handle cargo in small ports due their shallow draft and their own cranes. The latter also makes them independent of container terminals in major ports, thus speeding up turnaround times. Seatrade focused their marketing on the idea: "Fast, Direct, Dedicated" to differentiate their service offer from those offered by the container lines. Seatrade increased its investment in containerisation in 2016 by placing a 55 million dollar order with Maersk Container Industry for 4 ooo reefer containers. A meeting room at the Antwerp office was constructed out of the internal walls of a refrigerated container in $2015^{15}$. This initiative physically brought the container into the lived reality of the office. To us, this represents a will to embrace containerization in an industry which has often been reluctant to do so. In 2017 a planned vessel sharing agreement with the major container line CMA CGM was announced. This agreement would replace Seatrade's existing New Zealand line and would employ six of the company's new reefer-container vessels.

Seatrade also returned to its roots in 2015 by developing and then ordering four new reefers to support the fish trades. These $300000 \mathrm{cbf}$ vessels are 
dubbed as "freezers" although they can also carry goods at cool temperatures. They are equipped with derricks, rather than with cranes, to facilitate fish transhipments on the high seas. There was an also an option for a further four of these vessels, all of which are intended for the GreenSea pool..$^{16}$ Seatrade also ordered a new juice carrier at around the same time, replacing the old Joint Frost which dated back to 1979. Expected delivery of this ship, the Juice Express, was June $2017 \cdot{ }^{17}$

\section{$11 \quad$ Green Reefers}

Odfjell, Chairman and owner of the Bergen-based Nomadic Shipping A/S and Skibsaksjeselskapet Storli, entered the reefer market in 1993. Nomadic was the holding company while the name of the commercial pool was Green Reefers. Odfjell's short move into reefers was because he was convinced by Ronhovde to receive two reefers. In 1998, Odfjell sold to Eidesvik and in 2001 the pool consisted of 20 small size reefers. The parent company Nomadic exited the dry cargo market and concentrated fully on reefers in 2002. In 2003, a collaboration between Green Reefers and Seatrade was initiated and in the same year, Odfjell came back, acquiring 7.3\% in Green Reefers. Kristian Eidesvik, the 40\% owner of Green Reefers bought shares in Star in 2004. Green Reefers expanded in the mid-200os. Among other things Green Reefers bought ships from Seatrade in exchange for ownership shares. In 2007, the fleet consisted of 47 vessels. Eidesvik strengthened his ownership position in Green Reefers, acquired another $10 \%$ of the shares in 2007. In 2008-2009, Green Reefers made some cutbacks and made a new stock offering in 2010. Green Reefers also started collaborating with Silver Sea, which had 13 small reefers of 104000 to $190000 \mathrm{cbf}$. Together they formed the SilverGreen pool. In 2010, Green Reefers joined Hamburg Reefer Chartering with all its 27 ships. The main owner, Eidesvik announced in 2010 that he planned to take over Green Reefers. In 2011, his ownership share was $66 \%$. In 2012, Green Reefers pulled out of Hamburg Reefer Chartering to team up with Seatrade in the GreenSea pool. The strategy seems to be to keep being in the reefer market, but maintaining status quo. In 2016, they have a fleet of 24 owned reefer vessels from 265000 to $375000 \mathrm{cbf}$. In the same year Green Reefers also discontinued its joint-venture with Silver Sea.

16 "Management corner". Simply Seatrade 2015/2 p. 3 and "300,000 cubic feet handy-size reefer". Simply Seatrade 2015/2 p. 15 .

17 “Juice Express". Simply Seatrade 2015/2, p. 14. 
TABLE 12 Seatrade Fleet List 2016

Specialised Reefers operated by Seatrade Reefer Chartering

\begin{tabular}{|c|c|c|c|c|c|}
\hline Name & Built & Cbf & FEU slots & Reefer FEU & Pallets \\
\hline Baltic Klipper & 2010 & 661636 & 249 & 200 & 9392 \\
\hline Atlantic Klipper & 2011 & 661530 & 249 & 200 & 9392 \\
\hline Swedish Reefer & 1992 & $6455^{86}$ & 164 & 147 & 8671 \\
\hline Schweiz Reefer & 1992 & $6455^{86}$ & 164 & 147 & 8671 \\
\hline Italia Reefer & 1992 & $6455^{86}$ & 164 & 147 & 8671 \\
\hline Hellas Reefer & 1991 & $6455^{86}$ & 164 & 147 & 8671 \\
\hline Nederland Reefer & 1991 & 645586 & 164 & 147 & 8671 \\
\hline Lombok Strait & 2002 & 626011 & 220 & 200 & $95^{61}$ \\
\hline Luzon Strait & 2002 & 626011 & 220 & 200 & $95^{61}$ \\
\hline Atlantic Reefer & 1998 & 597139 & 226 & 200 & 9155 \\
\hline Pacific Reefer & 1999 & 596925 & 226 & 200 & 9154 \\
\hline Lady Korcula & 2000 & 590227 & 120 & 120 & 7632 \\
\hline Lady Racisce & 2000 & 590227 & 120 & 120 & 7632 \\
\hline Summer Flower & 1984 & 589903 & 82 & 82 & 6506 \\
\hline Summer Meadow & 1985 & 590102 & 82 & 82 & 6505 \\
\hline Royal Klipper & 2000 & 580754 & 207 & 185 & 8710 \\
\hline Comoros Stream & 2000 & 580754 & 207 & 185 & 8710 \\
\hline Hansa Lubeck & 1990 & 590654 & 99 & 80 & 6666 \\
\hline Hansa Bremen & 1989 & $5^{87974}$ & 99 & 80 & 6640 \\
\hline Polarstream & 1999 & 564280 & 136 & 109 & 7100 \\
\hline Polarlight & 1998 & 564160 & 136 & 109 & 7099 \\
\hline Elsebeth & 1998 & 549326 & 106 & 106 & 6837 \\
\hline Emerald & 2000 & 548718 & 106 & 106 & $685^{\circ}$ \\
\hline Elvira & 2000 & 548666 & 106 & 106 & $685^{\circ}$ \\
\hline Esmeralda & 1999 & 548643 & 106 & 106 & $685^{\circ}$ \\
\hline Crown Emma & 1996 & 547680 & 96 & 96 & 6638 \\
\hline Pacific Mermaid & 1992 & 540572 & 73 & 65 & 5902 \\
\hline Atlantic Mermaid & 1992 & 540026 & 73 & 65 & 5895 \\
\hline Tasman Mermaid & 1993 & 539670 & 73 & 65 & 5897 \\
\hline Caribbean Mermaid & 1993 & 539648 & 73 & 65 & 5897 \\
\hline Coral Mermaid & 1992 & 539634 & 73 & 65 & 5895 \\
\hline Timor Stream & 1998 & 535112 & 166 & 126 & 7068 \\
\hline Agulhas Stream & 1998 & 535109 & 166 & 126 & 7068 \\
\hline Benguela Stream & 1998 & 535109 & 166 & 126 & 7068 \\
\hline Klipper Stream & 1998 & 535109 & 166 & 126 & 7068 \\
\hline
\end{tabular}


TABLE 12 Seatrade Fleet List 2016 (cont.)

\section{Specialised Reefers operated by Seatrade Reefer Chartering}

\begin{tabular}{lccccc} 
Name & Built & Cbf & FEU slots & Reefer FEU & Pallets \\
\hline Discovery Bay & 1997 & 534246 & 100 & 100 & 6486 \\
Southern Bay & 1997 & 535 o93 & 90 & 73 & 5948 \\
Eastern Bay & 1997 & 533899 & 90 & 73 & 5941 \\
Mexican Bay & 1994 & 542905 & 63 & 44 & 5691 \\
Fortuna Bay & 1993 & 542470 & 63 & 44 & 5691 \\
Regal Bay & 1993 & 526250 & 67 & 46 & 5353 \\
Fegulus & 1993 & 526141 & 67 & 46 & 5351 \\
Atlantic Acanthus & 1999 & 504511 & 88 & 80 & 5963 \\
Messina Strait & 2004 & 460498 & 382 & 192 & 7782 \\
Magellan Strait & 2003 & 460498 & 382 & 216 & 8262 \\
Santa Catharina & 2000 & 463986 & 115 & 115 & 6194 \\
Santa Maria & 1999 & 463963 & 124 & 124 & 6374 \\
Santa Lucia & 1999 & 463652 & 124 & 124 & 6374 \\
Cold Stream & 1994 & 456785 & 113 & 106 & 6072 \\
Pacific Breeze & 1990 & 459861 & 66 & 66 & 5275 \\
Runaway Bay & 1992 & 516227 & 19 & 19 & 4813 \\
Aconcagua Bay & 1992 & 512361 & 19 & 19 & 4845 \\
Humboldt Bay & 1990 & 508551 & 0 & 0 & 4435 \\
Fuji Bay & 1990 & 502514 & 0 & 0 & 4438 \\
Everest Bay & 1989 & 449201 & 0 & 0 & 3954 \\
Whitney Bay & 1990 & 449175 & 0 & 0 & 3945 \\
Prince of Waves & 1993 & 402900 & 52 & 50 & 4461 \\
Prince of Tides & 1993 & 402574 & 52 & 50 & 4444 \\
Bay Phoenix & 1993 & 400884 & 6 & 6 & 3562 \\
Lagoon Phoenix & 1993 & 400884 & 6 & 6 & 3562 \\
Water Phoenix & 1992 & 400884 & 6 & 6 & 3562 \\
Green Italia & 1994 & 377100 & 45 & 29 & 4003 \\
Green Honduras & 1992 & 376221 & 45 & 29 & 3994 \\
Green Chile & 1992 & 375477 & 45 & 29 & 3987
\end{tabular}

Reefer Container Vessels

\begin{tabular}{llllll} 
Name & Built & $\begin{array}{l}\text { Cont. } \\
\text { slots }\end{array}$ & $\begin{array}{l}\text { Reefer } \\
\text { FEU }\end{array}$ & Pallets & DWAT $^{\text {a }}$ \\
\hline Seatrade Orange & 2016 & 2259 & 674 & 13480 & 27200
\end{tabular}


TABLE 12 Seatrade Fleet List 2016 (cont.)

Reefer Container Vessels

\begin{tabular}{lccccc} 
Name & Built & Cbf & FEU slots & Reefer FEU & Pallets \\
\hline Seatrade Red & 2016 & 2259 & 674 & 13480 & 27200 \\
Seatrade White & 2017 & 2259 & 674 & 13480 & 27200 \\
Seatrade Blue & 2017 & 2259 & 674 & 13480 & 27200 \\
Seatrade Green & 2017 & & 770 & & \\
Seatrade Gold & 2017 & & 770 & &
\end{tabular}

Seatrade vessels operated GreenSea Chartering

\begin{tabular}{lccc} 
Name & Built & Cbf & Pallets \\
\hline Sierra Queen & 1996 & 398470 & 3588 \\
Asian Cosmos & 1998 & 373827 & 3205 \\
Prince Of Seas & 1993 & 371412 & 3122 \\
Cool Expreso & 1994 & 362351 & 3267 \\
Nova Florida & 1989 & 298320 & 2661 \\
Breiz Klipper & 1991 & 265246 & 2382 \\
Sierra King & 1989 & 261262 & 2243 \\
Sierra Lara & 1996 & 260 050 & 2216 \\
Sierra Laurel & 1998 & 260 050 & 2216 \\
Sierra Leyre & 1997 & 260 050 & 2216 \\
Sierra Loba & 1997 & 260 050 & 2216 \\
Nova Zeelandia & 1986 & 238985 & 2033 \\
New Takatsuki & 1991 & 237136 & 1933 \\
Coppename & 1990 & 212102 & 1858 \\
Reefers ordered for the Greensea Pool & \\
Name & Built & Cbf & \\
\hline Orange Sun & 2017 & 300 ooo \\
Orange Sea & 2017 & 300 ooo \\
Orange Stream & 2018 & 300 ooo \\
Orange Storm & 2018 & 300 ooo & \\
& & &
\end{tabular}

a DWAT or "Deadweight all told" expresses the quantity of goods a ship can carry including provisions, lubricants, and fuel. This is usually what is referred to when we write deadweight tonnage, DWT.

Source: $<$ http://www.seatrade.com/fleet/> accessed o6/11/2016. Some data also from Simply Seatrade Issue $1 / 2016$. 
Seatrade grew out of a coaster operation with sailing ship owners, who in the late 1950 s when the general cargo markets fell decided to diversify. The subjective feeling of the company was very much one of local hands-on entrepreneurs with extensive knowledge about everyday shipping operations. A younger generation took over in the early 1970 s and from that point expanded with new customers towards an increasingly internationalized operation. They derived pride from their development of the fish trades, but an important step was also to gradually move into the large reefer trades with bananas and other fruit, something that was made possible by strategic acquisitions of ships and competent people. Similar to Salén in the 1950s through the early 1980 , Seatrade continuously built new vessels allowing them to gradually improve the ship design and their market knowledge. The company grew while other reefer operators were struggling in or exiting the segment from the $1980 \mathrm{os}$ through the 200os. Many profitable sales and purchasing activities were done, perhaps the most spectacular was the acquisition of Dammers and van der Heide. Similarly to the impression of the Danes by Swedes at Cool Carriers after the merger with Lauritzen, Seatrade was perceived by many as a deal oriented, fast, and tough business partner. And much more so than the Danes. The company was seen to find new creative solutions to old problems, and always trying to think outside of the box, in unconventional ways. This was not always meant positively, but was also expressed as a form of discursive criticism by the established parties such as Lauritzen and Cool Carriers. Still, by engaging in this unconventional way of doing business always trying to fill the ships with whatever cargo and keep the ships in business no matter what, in addition to the fast sales and purchase activities, the company remained profitable while the competitors were struggling. Seatrade did not only manage to grow but to a certain extent redefined what an independent reefer operator was. In the last few years, rather than positing themselves as pallet-based or conventional, they embraced containerization and adopted a discourse of specialized reefers - "fast, direct, and dedicated". Similarly to how Mats Jansson of Cool Carriers described that the battle between reefers and containers was inadequately expressed discursively, Seatrade was not only able to grasp this misleading dichotomy but also had the financial muscle to change it. They were the first reefer operator to build all-container reefers and to change the subjective perceptions of the co-workers they even used a container to create a meeting room in their head office. 


\section{Japanese Specialized Reefer Companies}

Japan has been a major importer of perishables after the Second World War and also has a long tradition in shippingㅁ. Unsurprisingly, they have been major actors in the reefer industry. Besides the large shipping conglomerates, the Japanese reefer industry also has its origins in the fish industry.

Japanese Fisheries

Japan was struggling to secure an adequate food supply following its defeat in World War II. A fleet of trawlers was built to fish in distant seas, for example off the coast of Argentina, Brazil, and South Africa. After getting a successful catch the fish would be frozen and transported back to Japan with purpose-built reefers (also known as freezers). The reefer today still under Japanese law is classified as a number three category fishing vessel (Japanese: Daisansyugyosen).

Years passed, and the regulatory environment started to change. In the 1970s the United Nations affirmed that each country could have an exclusive economic zone extending 200 nautical miles from the coast ${ }^{2}$. Within this zone, each country had control over various activities such as fishing, mining, and exploration and production of oil or gas, although ships from other countries had the right to pass through. For the Japanese fishing companies this meant that from the late 1970s, several fishing grounds were excluded, even though concessions were negotiated with various governments. Some fishing companies became fishtraders and worked with import and export. Others established joint ventures with foreign companies, selling part of their fleet to them and manning those ships with local people. In order to provide employment for the seafarers that had been laid off, the companies expanded into the reefer trades. In combination with the reluctance to lay off people, this stimulated the entrance of the fishing companies to the broader reefer industry, including the major fruit trades. There were four major fisheries. The biggest was Maruha

1 The part about Japanese reefer operators is based on Nissui. 2012 and NYK. 1988. 日本郵船 株式会社 100 年史 (Nippon Yusen Kabushiki Gaisha 100 Nenshi), articles in TradeWinds, as well as interviews with key people in the Japanese reefer industry.

2 United Nations Convention on the Law of the Sea, UNCLOS III. 
Taiyou Gyogyo, followed by Nippon Suisan also known as Nissui, and Nichiro Gyogyo and Kyokuyo, or KY. It was the latter two who were the first to diversify.

\subsection{Kyokuyo}

Kyokuyo Gyogyo, literally "polar sea fishing", were heavily involved in the whaling industry, which was stagnating. They were part of a business network in the Shikoku region, who had previously invested in the company's fishing vessels. They supported Kyokuyo's attempt to build reefers for the fruit trades. The first ship was delivered around 1973. Ships were delivered almost every year, and there were about 45 ranging from 150000 to $350000 \mathrm{cbf}$ by the late 1970s. Kyokuyo built ships for their own operation. However, a few ships were timechartered out servicing trades with apples, kiwi, squash from New Zealand to Japan, and bananas and pineapples from Philippines. Kyokuyo serviced the Japanese market and mainly sailed in the Pacific.

The reefer segment became an important part of the company, partly due to the role of Mr. Ishise, the manager of the reefer operations, that later became the president of the company. However, the interest in reefers from the company's management dwindled, and in combination with declining returns and dull market prospects, Kyokuyo decided to gradually exit the segment starting in the early 1990s. They have redelivered ships to their owners, scaling down their activities and terminated its shipping activities in August 2016.

\subsection{Nichiro}

Nichiro Gyogyo means "Japan-Russia fishery", but despite its name, it could no longer catch trout and cod in Russian waters due to the enlargement of the economic zones. Rather than focusing on the Pacific, that Kyokuyo had done, Nichiro was very active in the European market. According to respondents, Nichiro learned the reefer trade from European brokers, and even started their own office in Hamburg, to get information and to be able to act more swiftly. Nichiro was seen as an aggressive new entrant to a market that was dominated by Salén and Lauritzen.

Nichiro built Yamato Reefer in 1978 at Shikoku, in a period in which the shipyards were very hungry for orders. It was followed by the Shikishima Reefer, delivered in 1979, with a capacity of 193000 cbf. Then they built Sky Reefer and Sunny Reefer ( of $250000 \mathrm{cbf}$ each) built also in 1979. The Sakura class reefers of five ships was delivered from 1978-1980 ${ }^{3}$. Bizen and Bungo Reefer were delivered in 1983, followed by four Shrine type ships from Hitachi Zosen in 1983-4. Also, a ship called Sanuki Reefer was delivered in 1986. Nichiro's reefer business is held

3 Tokyo, Ariake, Akebono, Sakura, Fuji 


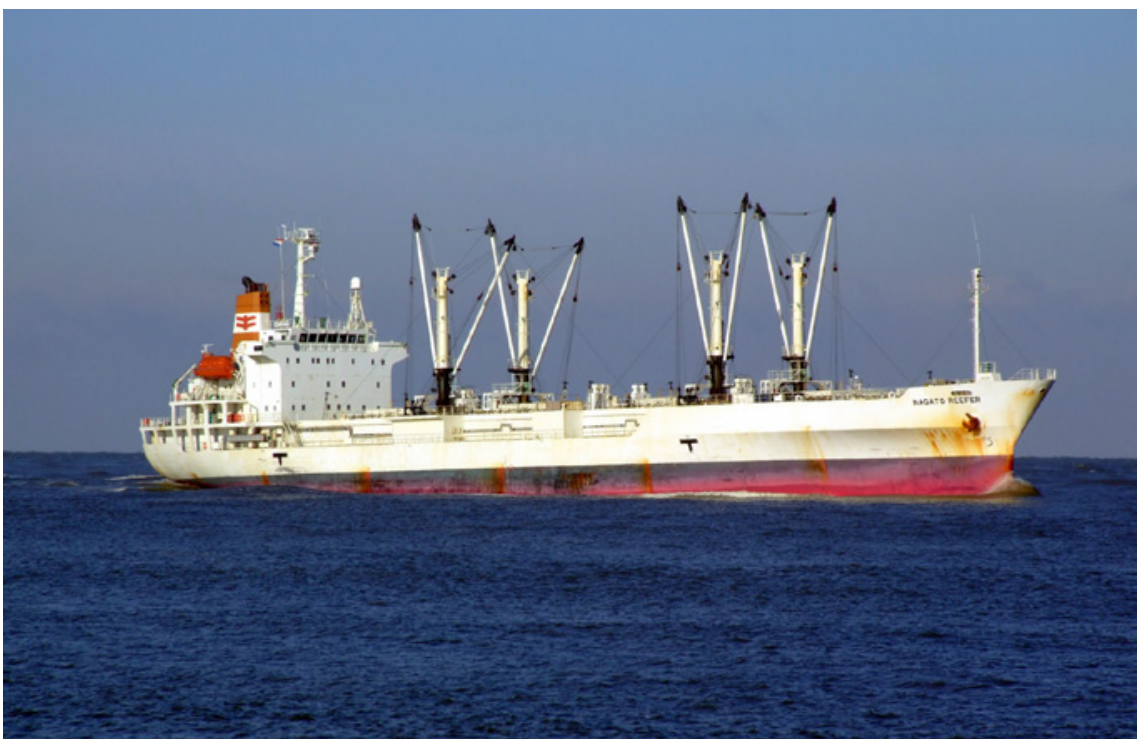

FIGURE 17 Japanese fishing companies originally acquired reefers to service their fishing fleets but later entered the fruit trades with ships like Kyokuyo's Nagato Reefer built in 2000. The ship sails in 2018 as the Frio Nagato in the Alpha Reefer Pool PHOTO: ALFVANBEEM (2007)

to have been of moderate importance for the Japanese reefer industry. They have operated both independently and together with NYK.

Nichiro controlled a fleet of 20-25 ships from 200-430 000 cbf. Given that a main reason for diversifying into reefers was to protect employment, it is not surprising that when the seafarers gradually became older and retired, much of the raison-d'être of the reefer section diminished. The shipowners, that Nichiro had mobilized for expansion into reefers, gradually sold off their ships, or employed them with another operator. The development of exchange rates also affected profitability as the cost of the ship was in yen but the income was in USD. Similarly to Kyokuyo, it was decided that the reefer division would be dismantled in the mid-199os. Rather than a gradual phase-out, Nichiro quickly dismantled its shipping activities.

In the early phase of the expansion of the Japanese reefer fleet, the international market for transportation of refrigerated goods was growing, which meant that the extra capacity provided by the Japanese fisheries was absorbed by the market. However, their entry was a shock to established players in the 
international reefer market. Both Japanese and European respondents have pointed to the limited English language skills of the new entrants. This combined with their fishing background and their status as new entrants kept them apart from the mainstream reefer establishment. Established actors were hostile towards these new entrants who built their own ships which subsequently increased the amount of tonnage available on the world market.

Following the move by the smaller fishing groups, we will now describe how the largest fisheries, Maruha and Nissui, also diversified into reefers.

\subsection{Nissui}

Nissui was experiencing similar problems as Nichiro and Kyokuyo, but since Nissui was a bigger company, it could wait longer until it saw a need for diversification. Senior management in Nissui decided to develop the business of transportation ${ }^{4}$.

A project team started to look into the business of fruit distribution in 1976 . Respondents indicate that the move from fish to fruit was relatively unproblematic. Furthermore, Nissui had extensive contacts with the dominant actor at the time - Salén. The project team went around the world, talking to shipowners and brokers, and finally built two reefers of about 430 ooo cbf5. A timecharter agreement was struck with United Brands for 2-3 years at a rate of 53-55 cents per cbf which was not enough to cover the costs of the ship. After building the two ships, Nissui contracted about ten newbuildings from other owners. The market collapsed and United Brands offered to renegotiate a charter at 34 cents, Nissui declined and decided to start their own operations. Mr. Ikeda, part of the project team, explains: "Nissui had a fish carrier called Isokaze Maru, built in 1976, and I was its chief mate directly after it was built. We asked NYK to run the ship off season. I still remember one trip, we carried NZ apples to the Middle East. We're able to carry apples for the first time. I thought "we can do that", so why do we ask another company to do it? If I wouldn't have had this experience, we might not have done our own operation."

Nissui's operation struggled in a poor market and was burdened by expensive crewing costs, since Nissui was a member of the employee union. Mr. Ikeda, now manager of the unit, tried to seek collaborators in companies such as Maruha, NYK, Lauritzen, Salén, Reefer Express Line. The potential partners were claimed to be too big or too proud to collaborate. Mr. Ikeda realized that he had to find a company with a more appropriate size. At a meeting in the Canary Islands before a tender for carrying tomatoes and fruits to the

4 Nissui 2012, pp. 239-240.

5 Asama Maru built in 1978 and Ikoma Maru built in 1979. 
European continent, Mr. Ikeda ran into Geert Pepping from Seatrade. At that time, in 1985, Seatrade and Nissui were almost of the same size, controlling about 25 ships each. Both companies also had a background in the fish trades. From 1986, they collaborated on the Canary trades. At the same time, the market started to look better for reefers.

But Mr. Ikeda felt disillusioned. He explains that Nissui, however much they were in the transport business, still in its "genetic coding" it was a fishery company. The organization was too slow in approving reefer investments because the managers were knowledgeable about fishing, not shipping. In 1991, Mr. Ikeda finally took the step and left Nissui Shipping to create East West Navigation. Nissui Shipping's fruit division continued to struggle with its profitability and at the end of the 1990s, it was decided to dismantle Nissui Shipping.

This dismantlement was seen as an opportunity for other actors to acquire reefers at a low price. A conflict ensued between Mr. Ikeda and Seatrade on the one hand and a broker, Mr. Nagaki, who worked with Nissui Shipping's management and Dole. Mr. Ikeda wanted to bring the whole fleet to Seatrade and was in negotiations with Nissui's central top management. Mr. Nagaki, on the other hand, wanted to separate the fruit carriers into a new company, since Dole disliked the idea of being in the hands of a major reefer operator such as Seatrade. Dole were perfectly happy with the service they got from Nissui, and wanted to continue operations as they were.

Nissui's shipping activities were eventually divided into two major parts: the fruit carrying division became Fresh Fruit Carriers, and the fish transportation division became part of the joint venture Tokyo Reefer Chartering, with Seatrade. Tokyo Reefer Chartering hoped to access Nissui's fish transport requirements, but results were disappointing, and the ships were soon integrated into Seatrade

Fresh Carriers was initially owned $60 \%$ by Nissui and $40 \%$ by Fresh System, a repacking network in Japan. Nissui later sold its ownership stake and the new company invested in some ships. In 2015 they had three main customers: Dole (bananas from Philippines to East Asia), Zespri (Kiwifruit from NZ to East Asia), and timecharted ships to Africa Express Line.

\section{Toei Shipping}

Before the fishery companies started building fruit carriers, early ventures were made by Mr. Ken-nosuke Ohno. Having engaged in different shipping businesses in the 1960 s, he had a dream of building international fruit carriers. He approached Nissui in the mid-196os, but while Nissui deemed the idea to be sound, they had no intention to build fruit carriers 
at that particular moment. Mr. Ohno also approached NYK, but they responded in the same way. Mr. Ohno decided to go ahead with his ideas and built two fruit carriers delivered in 1972-3 (Touei Maru, Touyu Maru), of $420000 \mathrm{cbf}$. The lack of interest of the domestic market led Mr. Ohno to charter the ships to Salén. It would take another few years before the fishery companies built their own fruit carriers.

As has been seen, the fishery companies operated reefers for independent shipowners. To better understand the relationship between operators and ship-owners in the Japanese context, we will give a brief history of the ship-owner Toei Shipping. We have indeed already started the story about Mr. Ohno, the driving force behind Toei shipping, above. After having built the reefers that were chartered to Salén, Mr. Ohno was interested in expanding in the reefer segment. A barter agreement was made with Nissui shipping. Nissui badly needed to cut costs but they could not flag out the ships due to membership in the seamen's union. Mr. Ohno offered to buy three reefers built in 1961-1962 (Seiko, Hokko, and Toko Maru) and one oil-ore carrier and take personnel responsibility of 80 crew members. In exchange, Nissui let Mr. Ohno build two fruit carriers of $260000 \mathrm{cbf}$, which was to be timechartered by Nissui.

But in 1978, a big change happened in Nissui, which came to affect Toei Shipping. One of Nissui's crude oil tankers caught fire and exploded, killing 2-3 crew members. This led to the resignation of Mr. Takeko, the Nissui shipping general manager, who had agreed on timecharter agreements with Toei Shipping, and the timecharter contracts were cancelled. Mr. Ohno had independently negotiated a timecharter agreement for the newbuilding Tama Ace to Reefer Express Line (the ship was renamed Tama Rex). The three older reefers were sold to Lavinia and they were cash cows in Laskaridis growing shipping business.

For the moment, the crisis was over, but Mr. Ohno became ill, and the banks forced Mr. Ohno's son - Sadaya Ohno - to take over the company in 1985. Before Sadaya Ohno took over the business, another barter was made between Nissui and Toei Shipping. In exchange for Toei Shipping taking over Asama and Ikoma (built in 1978-1979) plus an agreement to have Nissui's Japanese officers onboard and chartering the ships back for 8 years, Toei Shipping could build two newbuildings Tama Hope and Tama Star, delivered in 1986 and 1987. But another crisis happened due to the Plaza Accord, where the value of the yen rose dramatically. Sadaya Ohno started to restructure the company but due to his young age (he was in his thirties), he couldn't get the banks' support. Rather, an external member from Nipponkai Heavy Industries Co. (where Toei Shipping's 
ships were built) was recruited to be CEO of the company. Mr. Ohno took over full management in 1993 .

But before this, there were other problems with Nissui, the charterer. The head of Nissui shipping told Sadaya Ohno that Asama and Ikoma were in very bad shape and deteriorated the image and business of Nissui Shipping. Therefore, Toei shipping lost the contract for Asama and Ikoma, although the newer Tama Hope and Tama Star continued sailing for Nissui. The reason for why Asama and Ikoma were in bad shape was due to the current shipmanager. Given Sadaya Ohno's relationships with Mr. Ikeda, and Mr. Ikeda's relationship with Seatrade, a meeting was set up. Mr. Ohno let Seatrade's shipmanagement inspect the ship. Given the professional inspection by Seatrade, Mr. Ohno decided to try Seatrade as an operator. In 1995, Asama and Ikoma were sold to Rosewell Shipping, another Seatrade pool member. With the money from the sale of Asama and Ikoma, Mr. Ohno built Discovery Bay in 1997. The newbuilding contract was signed in December 1996 and the Hokuriku bank agreed to finance that project with 3 years TC by Seatrade at a level of about 72 cents per cbf. After three years, the ship was to go into the pool. But, there was an Asian financial crisis, and Hokuriku could not finance Toei Shipping. Finally, a leasing company was used to finance the ship. In 1999, Mr. Ohno wanted to built yet another reefer, Santa Catharina. The ship was to enter pool operation directly, but without any timecharter agreement, it could not be financed by Japanese credit institutions. Rather, Mr. Ohno managed to get the Dutch bank ING onboard, until the yen crisis in 2000, when the bank withdrew from the deal. By agreeing with the shipyard to defer the payment, the ship could be ordered. When Tama Hope and Tama Star were redelivered from Nissui, Mr. Ohno employed them within the Seatrade pool in 2001, and has been employing all his ships in the Seatrade pool ever since.

\subsection{Maruha and Reefer Express Line}

The largest fishing company Maruha Taiyou was one of the players behind Reefer Express Line (REL), a Japanese-American cooperation. But to understand this cooperation, one needs to go back in time a little. After Japan's loss in World War II, many Japanese-Americans were in Japan as part of the American occupation. These people knew English and Japanese and worked as interpreters. One of these Japanese-Americans, a person named Kay Sugahara ${ }^{6}$

6 Biographical information about Kay Sugahara can be found in Kanazawa, T. "Kay Sugahara'Nisei Onassis." Tozai Times, 1(Aug. 1985): 1, 10-11, 20., Niiya, Brian. 2001. (ed.) "Sugahara, Kay." 
(1909-1988), had a mixed reputation. During the war, Japanese Americans had been treated very badly in the United States, and Kay who had the reputation of being a fixer, offered services to these people that if they wanted to move back to Japan, Kay could ensure that their money was safely transferred. Rumors have it that some of the money disappeared in these transactions. But Sugahara had something that was a great asset - an ability to handle international business. And soon he would be called Nisei Onassis ${ }^{7}$ (Nisei means second generation Japanese living abroad).

Maruha was controlled by the Nakabe family. Just after the war Mr. Nakabe wanted, as has been mentioned, to send vessels to fish in distant seas. The fact that Japan had no international agreements during the period of occupation made fishing activity problematic. It was difficult, if not impossible, to get hold of the bunker and supplies to ships. It was here that Kay Sugahara and Mr. Nakabe got together. Sugahara could help Mr. Nakabe to get what was needed. Nakabe was very grateful for this and compensated Sugahara handsomely. Years later, when the Japanese economy had recovered, Sugahara and Nakabe pondered on whether to do business together again. This was the basis for Reefer Express Line, which was a collaboration between Maruha and FairfieldMaxwell (Sugahara), which started in $1968^{8}$. Kay Sugahara passed away in 1988, and the business was run by his sons Bryan, taking care of tankers, and Byron, with the reefers.

Reefer Express Line's business idea was to find cargo for the ballast voyage that Maruha's reefers made after they discharged fish in Japan. And since all income was on top of the vessels' earnings as fish transporters, REL could offer low freight rates to customers. The vessels owned by Maruha, were handled by Japanese ship management, but were taken in by REL on timecharter or on voyage charter. Vessels were also chartered in from the market. The CEO of REL, Alex Hirschler together with Ira Heisler, ran an operation that has been described by our respondents as clever and speculative. Reefer Express Line did well and some important trades that can be mentioned are meat from Australia to the us and fruit from Chile to Europe.

Byron who was in charge of reefers also thought about the opportunity presented by Japan's export of cars. And this he connected to the additional opportunity that was presented by the abolition of citrus import quotas, resulting in larger imported quantities. The shipping associated with car export was

Encyclopedia of Japanese American History, Updated Edition. New York: Facts On File, Inc.

7 Hirahara, N. 2003. Distinguished Asian American Business Leaders, Westport: Greenwood p. 185 .

8 http://bermudafirm.com/ja/reefer-express-lines-pty-limited.29937.company\#top_info 
basically unidirectional, the car carriers returned to Japan empty. Byron's idea was to combine these two opportunities. Byron approached Toyota with the idea of designing and building a special ship that shipped cars to the United States and returned with citrus. The deal was made and in 1978 Sunbelt Dixie was built at the Sasebo shipyard in Japan. The vessel was owned by Great American Lines - a joint venture between Toyota and Reefer Express Line. Although the ship was a reefer it looked like a classic car carrier. Sunbelt Dixie was replaced in 2002 with the Sunbelt Spirit with a similar configuration, however after 2014 it was only used as a car carrier. Specialised ships built for a particular trade are vulnerable to changes in the market.

REL had previously been in a unique position where they knew the transport market for refrigerated goods much better than the exporters who REL serviced. When these exporters began to travel and learn about the market, they realized that REL had outlived its purpose. For example, REL was a close partner and sole supplier of transport to Pacific Sea Highways (PSW) - an association of exporters from Chile established in 1980. However, many individual exporters left PSW to procure transportation services for themselves from companies that we know well, such as Cool Carriers and Lauritzen. REL had lost its competitiveness. In 1997 Maruha officially left the reefer segment and the ships were transferred to Reefer Express Lines. REL ceased to exist in 2002.

\subsection{Eastwind}

In the mid-1980s, when the shipping markets were deplorable, Fairfield Japan was approached by the Japanese bank Nissaigin that had 12 ships, including eight reefers in its books, since Shin Kurushima Shipyard had gone defunct. They desperately looked for buyers of these ships. One of the parties that were approached was Fairfield's Japanese subsidiary for shipping activities and shipping agency, called Olympic International, spearheaded by Yoshihiro Azuma. The bank gave Fairfield Japan good terms. According to hearsay, you could get more than $100 \%$ financing if you bought the vessels and employed them. Here, as so often, the stories diverge upon what really happened. According to one version, people at Fairfield Maxwell were not interested in the deal because of the bad markets, and therefore Azuma teamed up with John Kousi of Fairfield Maxwell to do the deal not for Fairfield, but for themselves. John Kousi, Don Simmons and Azuma broke out of Fairfield Maxwell and formed Eastwind in 1987. Simmons, Kousi and Azuma knew each other since they all worked at Fairfield Tanker. A second version is that Fairfield Maxwell was interested in the deal and that what happened was a coup schemed by Azuma and Kousi. 
Eastwind was established in 1987. Azuma's name is written as the kanji, the Japanese letter, for east, and thus the company was called Eastwind. Their business idea was to charter and operate tonnage of various types. Eastwind managed to secured a large fleet following the collapse of the Soviet Union. During the transition from planned economy to market economy, when the state broke down, government officials who had managed ships, became owners. Eastwind approached these new ship-owners at the right time. But they were not alone.

In 1991, Trans Ocean, a new pool, was led by Daniel Lev, a twenty-five year old from Russia, but the venture is also believed to be the brainchild of Sergei Yakubenko, who was employed by Far Eastern Shipping between 1978 and $1988^{9}$. Trans Ocean represented the interests Riga Reftransflot of Latvia, Lithuanian Klaipeda Shipping, Vladivostok-based Vostokrybkholodflot and Korf Shipping, Sevrybkholodflot of Murmansk, Kaliningrad Reftransflot, and the Crimean company Ygrybtranssbyt of Sevastopol. These fleets represented 95\% of the Soviet reefer fleet. The early years of Trans Ocean were highly lucrative and according to sources their fleet numbered over 100 ships. These were mainly old freezers that had been used in Soviet fishing operations.

Trans Ocean's domination of the post-Soviet reefer business made it also a target for other players. Representatives from Eastwind went to various shipowners within Trans Ocean and tried to get them to move their ships to Eastwind's pool. The Murmansk group left Transocean for Eastwind, and were followed by the groups from Sevastopol, Vladivostok and Kaliningrad.

Eastwind was mainly transporting frozen products like squid, fish, and poultry from Brazil, Argentina, Falklands to the Far East. Like all other operators, Eastwind wanted to enter the fruit segment, and were able to secure knowhow from the ailing REL, for example Toby Moors who joined in 1995. Eastwind's fleet grew, with several timecharters from Greek owners, and from having been a small niche operator, Eastwind was becoming a reasonably sized player.

Eastwind and Cool Carriers set up the ECO joint venture in 1997, with over 40 reefers serving various segments, including the more prestigious fruit business. Eastwind continued to run its own operation of frozen products, some of it in competition with Cool Carriers. Eastwind's collaboration with Russian interests was handled by Eastwind in New York, also with about 40 vessels. Even though Eastwind had a large fleet, Lauritzen and Cool Carriers did not treat Eastwind as a serious competitor because the freezer business was under the

$9<\mathrm{http} / / /$ www.marinemoneyoffshore.com/node/6411>. 
radar. For example, in one year, Eastwind carried 600 ooo tons of poultry from the us to Russia.

In the mid-200os, Eastwind began to expanded into several different shipping segments. They built new dry cargo vessels in China and operated fourteen tankers that were under the Bank of Scotland's auspices. They even bought container ships from Maersk. Unlike the reefer segment Eastwind had limited experience with these segments. This expansion might look reckless in hindsight, but the market was bullish at the time and many ship-owners expanded aggressively. Eastwind had over 100 ships prior to the financial crash in 2008 , and quite naturally they were heavily leveraged, with a lot of banks involved. Reportedly, only the reefer division was profitable. Some banks, including Nordea, pulled the pin when Eastwind could not fulfil its obligations. An insider recalls:

It was carnage. From a reefer perspective it was one of the biggest disasters that could happen because it devalued the world reefer fleet. Suddenly you dumped on the market 40-50 ships of varying quality. The ship called the Logan, 1990, $470000 \mathrm{cbf}$, went from being 18 MUSD to eventually 10 MUSD, but the ship was overpriced. Even a very good ship like the Logan lost 50\%. Every ship you owned became devalued. Eastwind maybe went from an asset value of 300-400 million, but were suddenly worth only 200 million.

Around 1965, the Japanese shipping lines entered into reefer trade. The shipping lines were organized in conferences that regulated how much cargo each company could transport, of what kind, and at what price. Refrigerated goods were part of traditional liner cargo as some of the holds in ordinary liners could be cooled. To embark on reefer shipping should thus have been counted as traditional line freight and would thus be subject to the tough conference regulation.

However, the Japanese shipping companies used other names for their operations within the reefer segment. NYK, which began operations in 1965, was called Japan Reefer Carrier. NYK, or Japan Reefer Carrier, competed with the aforementioned car-citrus-ship Sunbelt Dixie on the trade with citrus from Florida to Japan. The main trade for NYK under the 1970s and early 1980 s was frozen lamb from New Zealand to Korea and Hokkaido, as well as butter and 
cheese from New Zealand to the Middle East. Until 1997 NYK used the name Japan Reefer Carrier.

The competitor Mitsui osk Line worked under the name Satsumaru Kaiun. They also began operations in 1965 but gave up already in 1970 . What remains of Satsumaru Kaiun is the company Tokumaru Kaiun as a spin-off of Satsumaru Kaiun. Tokumaru Kaiun invested in reefers (Atlantic Reefer, Pacific Reefer, Tasman Reefer) and allocated some to the Cool Carriers Leonina pool.

The third major Japanese shipping giant K-LINE did not use a nickname for their reefer operations. Historically, K-LINE have been strong on the route between Japan / Asia and the Central and South American west coast. K-LINE began operations in the reefer segment by building a ship called the "M-type" used in their liner services, including the transport of bananas from Central and South America to Japan before Japan began importing bananas from the Philippines. The vessels were not fully reefers nor liners. They were, for example, strongly built so that they would not only be able to ship fruit (which is light), but also steel (which is heavy). Due to the short life of Satsumaru Kaiun and K-Line in reefers, the following part focuses on NYK.

When Mr. Michio Tamiya began at Japan Reefer Carrier in December 1981, he came to a business that constantly was in the red. The Japanese shipping companies had had difficulties to achieve profitability in the reefer trades, which led to both Mitsui osk Line and K-Line leaving reefer business during the early 1970s. Mr. Tamiya wondered if these red numbers were because the management system of NYK did not fit the reefer business. At NYK, every third or fourth year managers change position, educating generalists rather than specialists. Someone said that this system is similar to that of public authority. Mr. Tamiya suggested that he should work with reefers for ten years. At least.

In the summer of $1982 \mathrm{NYK}$ was in charge of four to eight chartered-in reefers. Since the company had been making losses, NYK had no permission to own ships. Returning to the history of the Japanese fisheries, it can be deduced that Mr. Tamiya came in just when the market collapsed after Maruha and Nissui had entered the market. He looked at the situation and thought that this probably is the right time to build new vessels according to the old shipowner philosophy that one should build when the market is at the bottom. It was decided from the management perspective that if one ordered two ships, one had to be for time-charter and the other for own operation. Some ships were delivered to NYK in the early 1980s, for example Kijima, Raffia Universal - a ship which was chartered to Universal Reefers, Ocean Onward and Ocean Pride, and two ships, Nienburg and Nordenham, built in 1984 and chartered out to Atlanta, the German importer of Chiquita Bananas. 
The reefer division of NYK gained permission to build two Harvest class vessels of 440 ooo cbf plus reefer container capacity at a price of two billion yen per ship. Originally, they were supposed to be owned by a private owner (Masumoto Kaiun) and timechartered into NYK, but the owner left the project because of the sudden devaluation of the Japanese Yen following the Plaza Accord. NYK took ownership of these ships instead, and favourable financing obtained through NYK's financial department, which due to internal struggles, had been encouraged to commission special loans to commercial divisions, loans that had very competitive interest rates. After some hesitation from the yard, however, the order was placed, with an option for another two ships, which were ordered later. The ships were ordered for own operation and therefore not to be time chartered out to any customer. At this time, the organization consisted of five people. The Harvest Class ships, six in total, were delivered from 1988 to 1990.

As we will see, there was a very large expansion in the own fleet of NYK's reefer division. Although, NYK's reefer division was of course aware of the challenge of containerization, the top management was confident that especially the banana trades would not be containerized in the near future. With this conviction, an aggressive expansion took place. The four Harvest vessels turned out to be a fortunate business, and right after these four vessels had been built, a new project started, with larger ships with more container capacity. The goal was to lease the vessels to banana companies in order to stabilize revenues for NYK. A collaboration began with Dole who chartered three ships. The three so-called Orion vessels were used in Dole's intercarib trade, for example between Colombia and the us Gulf. Distances were short and three vessels fully covered the service. Mr. Tamiya remembers that: "I visited Dole Boca Raton in Florida, with Mr. Nagaki, who was my broker. We visited Dole. Since then the Dole contract continues on".

The Mermaid class vessels (built in 1992-1993) were also developed for Dole. While Orion was used for short trades, with the Mermaid ships NYK achieved a transatlantic contract, Ecuador to the Mediterranean. All the five Mermaid ships were timechartered for periods of 5-7 years to Dole. Then there might have been a few more Mermaid ships for own operation.

1995 was the year when NYK Reefer had the biggest operation ever - a controlled fleet of 57 vessels and an organization of about 20 people. Then the Crown type ships were built and delivered from 1996. The reason for developing the Crown type was that the Mermaid ships were not popular with some shippers. The banana companies did not particularly like the special deck, a hatch coaming, which was installed instead of a traditional hold. Although this special deck was very suitable for stronger fruits such as apples and pears, it 


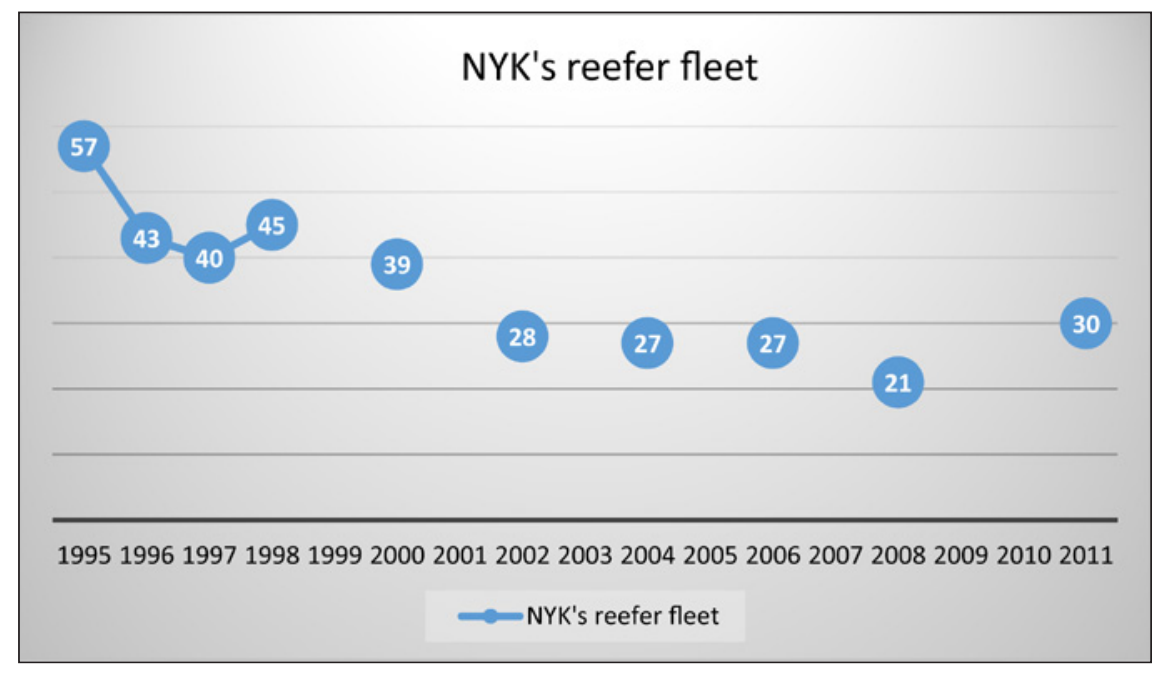

GRAPH 14 NYK's controlled reefer fleet

was difficult to maintain a steady and correct temperature for banana transport. Tamiya concludes: "The banana companies did not like it, so, we had to change to Crown." Although the market was not particularly good when the ships were ordered, NYK had to order them to keep business with Dole. The Crown vessels were both used for timecharter and in own operation.

Apart from the timechartered vessels to Dole, NYK developed the Phoenix class (390 ooo cbf), totalling seven ships, for its own operational fleet. Also, five ships in the Wild class (4995000 cbf) were delivered from 1998. When it came to NYKs own operations, it started with New Zeeland (1986), expanded into South Africa, and later into Chile, which was held to be a particularly difficult market to enter, due to the absence of a national marketing board. Without thorough knowledge of who is who in the market, it was impossible to do business. In 1988, NYK managed to get a contract for a minor trade with apples from Chile to Jedday (Mohammed Abdallah Sharbatly Corporation), and in 1990, they got into a major trade in Chile, with apples, pears and grapes. According to Mr. Tamiya: "The big trade of Chile was controlled by the major boys of Europe (Salén, Lauritzen, Cool)."

In other words, to get into that market was an accomplishment in itself. However, the success in the major Chile trade was short. The year afterwards, NYK lost the contract to Lauritzen.

Apart from the expansive development of the fleet, in the early 1990s, NYK was on the way to take over Stockholm-based Cool Carriers. Mr. Hiroshi Ishikawa, a key figure in NYK system who also founded both NYK Reefer and NYK 
Car Carriers, had an idea that something should be done within the reefers segment to create the conditions for a long term sustainable business. In 1990, NYK bought Ugland European Car Carriers (UECC) which then changed its name to United European Car Carriers. Making a similar merger on the reefer side was considered desirable. As Cool Carriers was the global market leader, it was considered to be an appropriate target. Mr. Ishikawa knew Christer Olsson, who was the CEO of Wallenius and a well-known person in Swedish and international shipping. With the assistance of Christer Olsson, negotiations began with Bilspedition to buy Cool Carriers. They discussed the money and it was largely a done deal. At least from NYK's perspective. But the employees spearheaded by Lars Gunnar Larsson rejected the bid from NYK and the deal never took place. Maybe it was because Cool Carriers were proud of their Salén past. This resistance was perceived from NYK's perspective as resistance for resistance's sake, without a clear idea of how Cool Carriers would develop. It was also a fact that during the early 1980 s NYK Reefer had only four ships in the fleet. That NYK would buy Salén, which had 100 ships at the time was unthinkable. And actually Mr. Tamiya remembers that he visted Saléninvest in the early 1980 s when the company had 100 vessels and appeared to make a profit of 100 million SEK per year. Tamiya was inspired and wanted to build his own Salén. And that was precisely what NYK would have to do now that Cool Carriers rejected their bid.

But the end of the 1990s were difficult years for NYK Reefer. In April 2000, some of the staff moved to London. Mr. Aoki who was the new head of NYK Reefer saw the need to restructure, and part of this was injecting fresh equity, and part was to internationalize by relocating to London. One should remember that NYK Reefer had been a very Japanese business, located in Tokyo, with Japanese employees. However, under Mr. Aoki's management, the company became more internationalized. Former employees from Universal Reefers and $\mathrm{P} \& \mathrm{O}$ were recruited. In October 2000 a task force committee was created with the name "Drastic Measure Task Force Team" (Bappon Taisaku Tasuku Foosu Cheemu). It was decided that NYK should leave reefers and instead establish a subsidiary in London, which would stand on its own. This subsidiary was created in November 2001.

2.1

NYK STAR

The cooperation with Star Reefers from January 2002 was initiated since the reefer market had collapsed and NYK was delivering poor results. Once again consolidation with other players was discussed, but this time, the idea was not to grow and become bigger as in the proposed merger with Cool Carriers in 1993, but rather to survive. NYK began discussions with Star Reefers which was 
a part of Blue Star Line (further covered in chapter 8). The container line part of the Blue Star Line had merged with P\&O but the traditional reefer part remained. Both NYK and Blue Star Line understood each other as traditional liner shipping companies, similar mentalities, and this seemed to be a good basis for a merger. Star were also chartering out many of their vessels while NYK focused more on their own operations, so there were synergies. There were also discussions with United Reefers, who had separated from Seatrade, and had a fleet of about 20 ships. NYK, United and Star were to form a joint venture comprising over 6o ships and thereby become an important competitor to Seatrade. However, as we have seen in other chapters, Star Reefers was taken over by Christian Siem.

NYK had the option of not proceeding with the planned Star collaboration after the latter's change in ownership. But they went ahead, the need to consolidate the business was great. Star Reefers had no interest in collaborating with United Reefers, since they perceived their vessels to be inferior, which led to the formation of NYKStar. The joint-venture boasted nearly 40 ships. But the partnership was a bad experience for NYK. Aoki from NYK was the CEO and Aage Thoen who Christian Siem had nominated as Chairman did not go well together. During the process Lars Rutberg from Cool Carriers was recruited to replace Aoki as CEO, to improve the business from NYK's perspective. Rutberg remembers that the management on the Star side weren't keen on him joining NYKStar, and even tried to block his appointment. From Rutberg's perspective, the pool operation was set up to favour Star. Attempts to renegotiate the pool parameters were dismissed by Star resulting in NYK's decision to cancel the joint-venture. Despite the fact that the cooperation failed and formally closed down in June 2003, NYK had not abandoned their idea to consolidate with another operator.

\subsection{NYKLauritzenCool and NYKCool}

Afterward the break-up, NYK looked for new partners, and finally the choice was LauritzenCool. Lars Rutberg had a background at Cool Carriers and according to Mr. Tamiya, Rutberg helped convince NYK to buy a share of Cool Carriers from Lauritzen. According to NYK, it was obvious that Lauritzen was exiting the reefer business. From NYK's perspective, it was important that Lauritzen would keep their fleet for about three years with a gradual phase-out.

In 2004, LauritzenCool entered a tonnage sharing agreement with NYK Reefers and NYK Reefers bought $50 \%$ of LauritzenCool Logistics. NYK bought $50 \%$ of LauritzenCool in January 2005, and NYKLauritzenCool was created. The company employed around 6o specialized reefer vessels and once again, the operations were headquartered in Stockholm. The strategy for these owners 


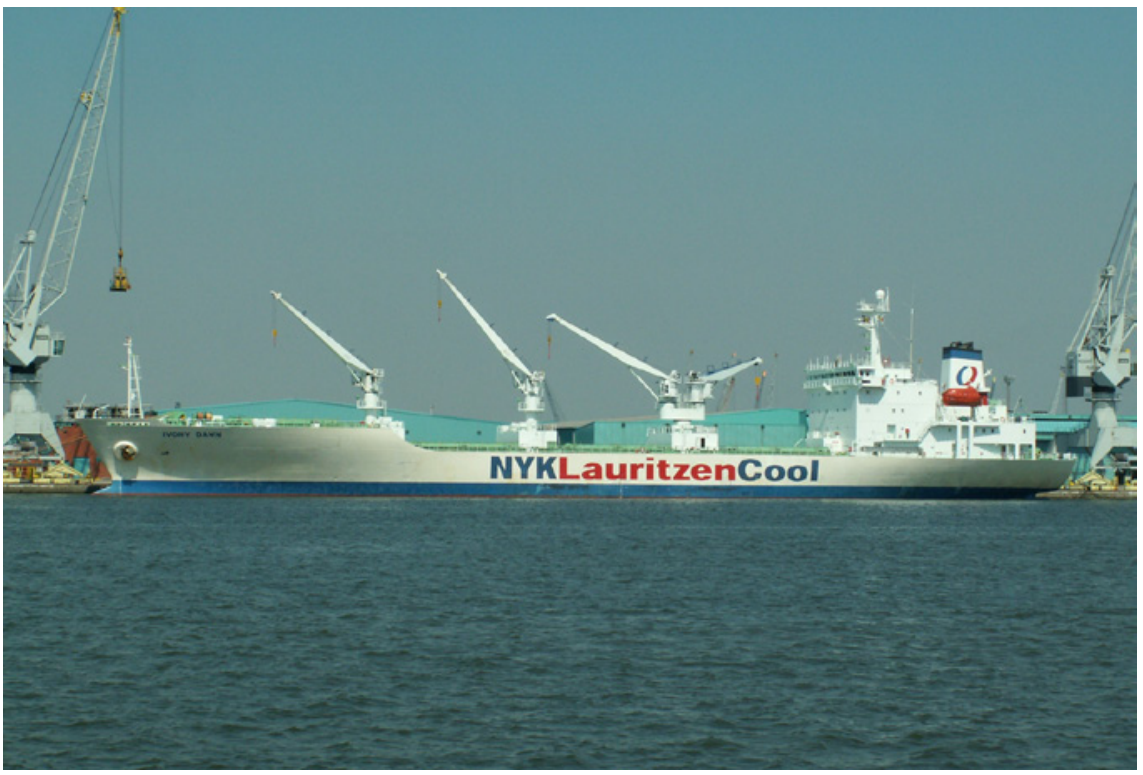

FIGURE 18 Consolidation was seen as a way to improve profitability in the years around 2000, and this gave rise to NYKLauritzenCool for a few years. After Lauritzen's and then NYK's exit, the operation reverted to the name Cool Carriers, owned by BalticShipping PHOTO: ALFVANBEEM (2006)

was to consolidate their operations, minimise their fleets, and focus on stable contracts with major fruit companies. Therefore, the ReeferShip venture with its older ships was dismantled. In 2007, Lauritzen completed its exit strategy and NYKLauritzenCool was renamed NYKCool. The old relationship between United Fruit and Salén, later between Chiquita and Cool Carriers, was still active in the early $21^{\text {st }}$ century. When Chiquita was in financial trouble in 2007, they turned to NYKCool with a proposal to sell and lease back 12 ships to improve their balance sheet. Initial discussions were held between NYKCool and Star to share the investment. NYK agreed to the deal, but eventually the investment was shared with Eastwind and Chartworld in the company Eystrasalt, from whom NYKCool bareboatchartered the ships. As part of the deal, a NYKCool affiliate, Seven Hills, was set up to handle all of Chiquita's spot chartering as well as the commercial management for the chartered vessels. However, the Eastwind bankruptcy in 2009, as a result of the financial crisis, caused these arrangements to fall apart. According to respondents who were at NYKCool, Chiquita took the opportunity to get out of the deal in the turmoil surround- 
ing the bankruptcy. After a year and a half, all contracts and the spotchartering business in Seven Hills were terminated.

LCL, which was providing door-to-door logistics solutions, had been another focus area for the company. However, this turned out to be overly ambitious and poor results followed. Particular problems had appeared in Spain, where they made significant losses.

As a result of these setbacks, the Japanese parent company wanted the Stockholm operation to focus on maritime reefer operations. In relation to this decision, Mats Jansson and Lars Rutberg decided to leave NYKCool. Jansson was replaced by Boris Gersling, with long experience in Lauritzen, particularly in Chile. According to small-talk in the industry, this change of cEo led to less autonomy at Cool Carriers. In other words, the locus of strategy was moved away from NYKCool, which from this point became the operations department of NYK Reefer, although the Leonina pool operation continued. A few attempts by the organization to invest in the segment were turned down. From the perspectives of the employees, the period under NYK ownership is depicted as one of gradual stagnation, following the decline in the industry. That some employees had to leave before their retirement age was also a cause of discontent. Additional anecdotal information also suggests that employee morale and group solidarity declined after Mats Jansson left in 2009.

In 2014, Baltic Shipping acquired NYKCool. This marked the end of NYK's history in reefers. Discussing the issue with Mr. Tamiya, he explains that he had mixed feelings about selling to Baltic. He had suggested to NYK that they should exit the reefer segment already in 2008 . He argues that the price that might have been obtained in 2008 was about 200-250 million USD, while the price in 2014 was far less. However, in 2008, the president of NYKCool said to Mr. Tamiya that it was "noted but a pity to give up the long-term operation of reefers. We started from scratch and grew organically. All of a sudden giving up is not good."

\section{Baltic Shipping}

Baltic Shipping has its roots in HSC Agency, which is run by Aveny Bich, the former managing director of the post-Soviet shipping company Klaipeda. Aveny had relations to Laskaridis and thus also to the Hamburg reefer cluster (see chapter 9). Bich's son, Oleg Bich, founded the Maritime Reefer Agency in Hamburg. Oleg Bich was instrumental in setting up Baltic Shipping in 1999. However, details regarding ownership and organizational structure of the company is largely unknown, but some of the ships in the fleet are owned by fruit importers Saptari and Sorus ${ }^{a}$. 
From 2013 Reefer Alliance was established together with Seatrade combining the fleets of the two companies in specific trade lanes. They had a fleet size of 96 ships from 350 to 626 ooo cbf. The fleet of Baltic Shipping is old, even in the context of the reefer industry. While the average age of reefers was 24 years in 2013, the reefer fleet of Baltic Shipping averaged 28 yearsb. Baltic Shipping acquired NYKCool in 2014.

The company's main services, at this time, were the transportation of fruit from Latin America and Africa to European ports, predominantly St Petersburg. It also operated a liner service from Brest and Vlissingen to St Petersburg. Another important business was the ship agency in St Petersburg which reduces turn-around time in that port ${ }^{c}$.

Notes: a "Russian importers buy up old reefers". TradeWinds 1 August 2002. <http://www. tradewindsnews.com/weekly/176407/russian-importers-buy-up-old-reefers >; b "Increase in Seaborne Trade Hides Uncertain Future for Specialized Reefer Vessels", The Maritime Executive, 24 September 2013, <http://www.maritime-executive.com/pressre lease/Increase-in-Seaborne-Trade-Hides-Uncertain-Future-for-Specialized-Reefer-Ves sels-2013-09-24.>;; c Baltic Shipping webpage, <http://www.baltic-shipping.com/en/ news.htm>.

\section{3}

\section{Summary}

To make a summary of all the Japanese operators is not a simple task. But one can say that the fishing companies entered the reefer segment as a way to either create employment for seafarers, to diversify into a segment which was related to the transport of fish following the implementation of the 200 miles economic zone, or to earn money on the ballast leg of fish transportation. Given the fish-related background, they were discursively positioned as outsiders by the established operators. This is somewhat similar to how Cool Carriers for a long time saw Seatrade as a fish carrying operator. Their lack of English skills corroborated this outsider identity. In any case, the Japanese fishing companies made a significant impact on the market given their ability to raise funding for a significant newbuilding programme. Much of the downturn in the 1970 s for the established operators was due to the Japanese operators entering the market.

The Japanese shipping companies' expansion into specialized reefer trades was first made in secret since they were regulated by liner conferences. The only player who remained within the reefer segment was NYK. It managed to get out of bad profitability in the early 1980 s and was able to stay profitable while significantly growing the fleet. From the early 1980 s to 1995 the fleet had grown from about 10 ships to over 50 ships. NYK was the only Japanese operator 
that was able to outcompete the established operators on core trades and NYK even tried to acquire Cool Carriers in the early 1990s. Similar to the other operators NYK Reefer was suffering from the market downturn at the end of the 1990s, and looked for ways to internationalize and consolidate, first with Star and after that unsuccessful attempt, with Stockholm-based LauritzenCool.

The Japanese operators were subjectively perceived and discursively constructed as outsiders, which is clear through references to cultural differences, black hair meetings, and just a fundamental incomprehension of what the Japanese operators were doing and what their aim was. The Japanese operators also saw themselves as outsiders trying to get into second-tier, and then firsttier customers. Given their newcomer identity the established actors were not willing to collaborate with the Japanese operators, apart from Nissui and the other "newcomer" Seatrade which started collaborating in the mid-1980s. NYK Reefer moved to London at the end of the 1990s and recruited non-Japanese people from other reefer operators. This most probably led to NYK Reefer becoming more accepted within the reefer community that since the beginning was centred in Northern Europe. 


\section{From Blue Star Line to Star Reefers}

Star Reefers is one of the few remaining independent reefer operators and has a fleet of modern vessels chartered to the major fruit companies. Today's operation is owned by Siem Industries and is a result of Siem's fusion of its previously acquired Swan Reefers and its purchase of the remaining vestige of the classic Blue Star Line. The latter, with its famous funnel logo, can trace its history back over a hundred years and its fortunes were inextricably linked to that of its owners and founders, the Vestey family.

In the late nineteenth century Samuel Vestey, a provisioner with a butchery, sent his sons, William and Edmund to the USA where a meat cannery in Chicago was established. The idea was to produce low cost corned beef to the business back in Liverpool. This venture was followed by the export from Argentina of frozen partridges and this gave the brothers exposure to the new technology of refrigeration leading them to open a cold store in England. The business was apparently successful and was publicly listed in $1897^{1}$. In 1903 the business had expanded with several cold stores around England as well as one in Riga ${ }^{2}$. The basic business idea was a follow-on from the meat cannery in Chicago: to provide cheap meat products to England and to the Merseyside in particular. The Vesteys identified that the burgeoning industrial population of the region was a potentially massive meat consumer, as long as it was inexpensive, and were able to tap into that demand.

It's fair to say that the Vesteys were pioneers in the application of refrigeration technology. The network of cold stores was expanding and, with hindsight, we can consider this as a necessary infrastructure that was a prerequisite for the development of refrigerated shipping. The Vesteys initiated a new venture from China in 1906 and the major business was eggs for the bakeries in the UK. Even though the Vesteys are associated with the meat trades it was the egg trade that led them to purchase two steamers that were converted to refrigerated vessels in 1909 .

The Vestey brothers formed Blue Star Line in 1911. The fleet grew and Argentina became a major centre for their operations, a cold store was opened at Zárate and the Allied armies in France were supplied with meat during the

1 Initial prospectus of the Union Cold Storage and Ice Company of Liverpool Limited from the Liverpool Daily Post, 23 Nov 1897, p.4.

2 The Standard, 17 Nov 1903, p 11. 
First World War. In Britain the Vesteys invested in retail butcheries that numbered over 2000 by the twenties. And by the 1925 Blue Star Line claimed to have the largest refrigerated fleet in the world ${ }^{3}$.

The vessels that Blue Star Line operated at this time had little in common with the reefers that we come across later in the century. These were multipurpose vessels with a frozen hold for meat, a regular hold for general cargo and they also carried passengers. In 1925 Blue Star Line ordered five large ships, known of as the A-class ${ }^{4}$. These vessels were completed two years later and carried 160-180 first class passengers particularly to and from Argentina, and also carried meat and other cargo. Modifications were made; the Avelona Star was converted to only carry cargo while the reverse was the case with the Arandora Star. The Arandora Star with its lavish furnishings and ballroom, swimming pool and tennis court, was the epitome of luxury cruising in the interwar years.

In 1933 the company began using refrigerated vessels to carry meat from Australia and New Zealand. An impetus to this was the preferential treatment accorded to the Dominions when the UK abandoned free trade. Farms on a gigantic scale were acquired in South America and Australia resulting in a most remarkable vertically integrated meat operation employing tens of thousands of people in the interwar years. All facets of the meat industry from the farm to the retail butchery were owned by the company and the shipping operation was just one link in the chain.

The Imperial Star class that followed in the 1930s and 1940s were motorships and while they carried passengers, they did not do so to the extent, or with the luxury, that the A-class did. The British Government pressed most of Blue Star Line's 38 vessels into service when the Second World War broke out in 1939. Twelve vessels remained in 1945. Blue Star Line's vessels were quite fast and frequently operated independently of the convoy system. The aforementioned A-class vessels could do 16 knots for example.

\section{Blue Star Line's War Service}

The Almeda Star was carrying passengers and cargo from Liverpool to the River Plate when she was torpedoed in 1941 by the German submarine U-96 ${ }^{\text {a }}$. Rescue parties were sent following a brief distress signal but they discovered no sign of her. The vessel was lost with all hands, including 194 passengers.

3 <http://www.bluestarline.org/william_vestey.htm>.

4 The Almeda, Andelucia, Arandora, Avelona and Avila. The name "Star" was added in 1929. 
The Andalucia Star was carrying meat, eggs and passengers from Argentina to England when she was torpedoed by U-101 at night off the coast of West Africa. During the evacuation the ship was repeatedly torpedoed. A four-year-old girl was discovered in the water some considerable distance from the lifeboats. A crewman swam to her and eventually they could be saved. The Stewardess that had turned on the girl's red electric safety light was never found. The lifeboats were later picked up by a Royal Navy corvette, miraculously only four lives had been lost.

The cruise liner Arandora Star was used as a troop and refugee transport in the first year of the war. In 1940 she was controversially tasked with transporting civilian Italian and German male internees, as well as German Pow's, to Newfoundland. The Arandora Star was torpedoed by U-47 off the coast of Ireland. A little over half of the people, many covered in fuel oil, were rescued on a Canadian destroyer sent for the purpose. Further searches discovered no further survivors. 805 people were lost and Blue Star Line never reused the name "Arandora".

The Avelona Star was the vessel that had been converted to only carry cargo. She was torpedoed by U-43 while in convoy carrying meat and oranges from Argentina. The survivors were picked by the French Beignon that was itself sunk later the same day. There were a few fatalities.

The Avila Star was carrying meat and passengers from Buenos Aires when she was torpedoed at night by U-201 in 1942. A further torpedo during evacuation caused additional casualties. The survivors of the sinking endured a tortuous journey in the lifeboats, with many fatalities due to wounds, dehydration and exposure before finally being rescued by Portuguese vessels. One of the lifeboats was lost at sea. 73 of the 199 people onboard perished.

Many of the other vessels of Blue Star Line suffered similar fates. A well known example is the Doric Star that was sunk by the infamous German "pocket-battleship" Admiral Graf Spee. While we are on the subject it ought to be mentioned that several Blue Star Line vessels were actively involved in military operations during the war, Norway and the Siege of Malta for instance. Blue Star Line lost 646 of its personnel during the Second World War and, as previously mentioned, most of its fleet.

Note: a See Taffrail, W. 1973. Blue Star Line at War, 1939-1945, London: Foulsham. An overview is available at $\langle\mathrm{http}: / /$ www.bluestarline.org $>$. 


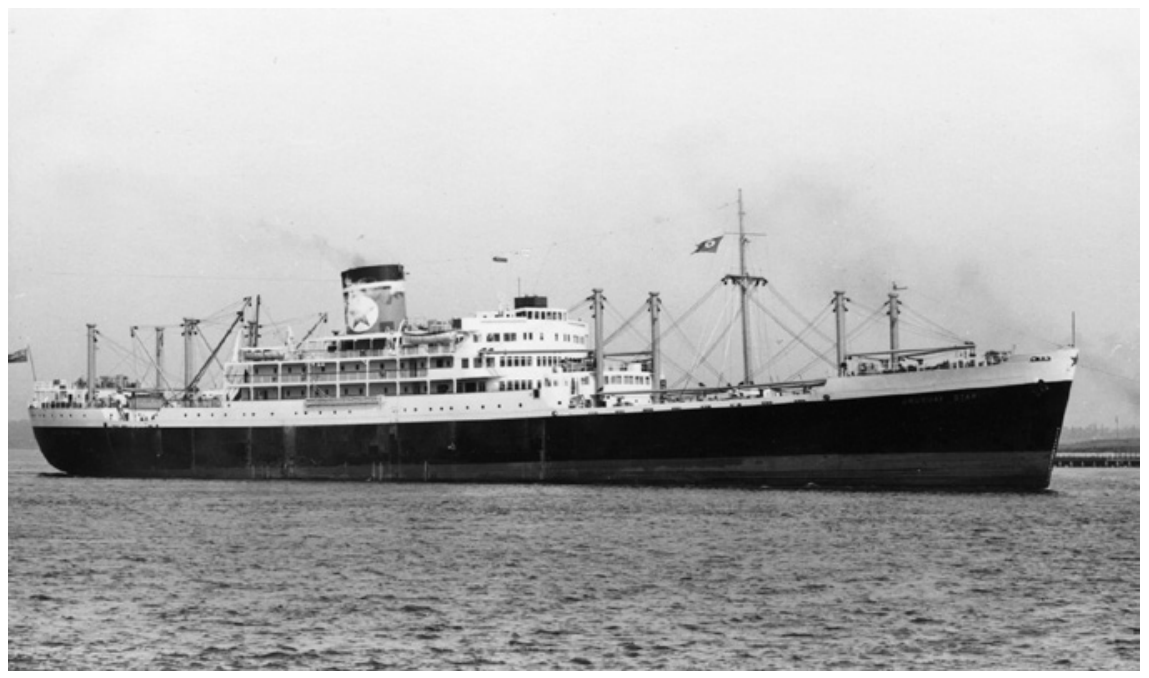

FIGURE 19 Prior to containerisation, many reefer cargoes, particularly meat, were carried in refrigerated cargo liners. Passengers were also carried, and vessels like the Uruguay Star had first class service PHOTO: BROWN, W.H./ SJÖHISTORISKA MUSEET

The British Ministry of War Transport built low-cost "Empire" ships during the war and some of these were purchased or chartered by Blue Star Line after the war ended to replace lost tonnage. Blue Star Line took over Lamport and Holt Line in 1944 and the Booth Steamship Company in 1946. Four replacements for the A-class were also ordered and completed in 1947 and 1948. These vessels were the Argentina Star, Brasil Star, Paraguay Star and the Uruguay Star. They resumed their first class service to South America but with fewer passengers and the luxury and opulence of the interwar era was a thing of the past.

\section{Entry into Specialized Reefers}

The link to Australia and Queensland's beef industry was identified by the names of vessels such as the Gladstone Star, Townsville Star, Queensland Star and Rockhampton Star in the late 1950s and early 1960s. These vessels and several other reefers that were built around the same time heralded the company's major entrance into specialised reefer shipping. The Wellington Star of $195^{2}$ was claimed to be the world's largest reefer at the time with a capacity of almost $600000 \mathrm{cbf}^{5}$. Services between New Zealand and Japan were

5 Collard, I. 2014. Blue Star Line: Fleet \& History, Gloucestershire: Amberley Books, p. 28. 
inaugurated and carried fruit as well as meat and fish. General cargo was also carried. A line that was later to become very important was started in 1962 carrying meat from Australia to the east coast of the USA and Canada. Many services were conducted jointly with other shipping operators.

Blue Star Line were pioneers in the field of containerised shipping. In 1966 they were one of the five British shipping companies that formed Associated Container Transport (АСт). The other members of the consortium were Ben Line, Cunard Steam Ship, Ellerman Lines and Harrison Line. In 1967 a corresponding company focused on Australia was formed ACT(A) by Blue Star Line, Ellerman Lines and Port Line. The funding of the new large container vessels required cooperation and the first of these vessels was the $A C T 1$ delivered in 1969. In the seventies there were various constellations of shipping companies including Blue Star Line that were concerned with containerised shipping ${ }^{6}$. The California Star and the Columbia Star were delivered in 1971 and besides carrying ordinary containers also carried 125 insulated containers for refrigerated cargo. Blue Star Line cooperated in the North Atlantic trade with the Danish East Asiatic Company as ScanStar which became Johnson ScanStar when the Swedish Johnson Line joined in 1972.

\section{Johnson Line}

The Swedish Johnson Line can trace its origins back to Axel Johnson's trading with coal, iron and steel in the late 19th centurya. Shipping enterprises followed and this included the Johnson Line, a liner company. The first Swedish vessels fitted with refrigeration were the Axel Johnson, Annie Johnson and Margaret Johnson operated by the Johnson Line after the mid-1920s. They were designed for the north Pacific trade and had refrigerated holds of $50000 \mathrm{cbf}$. Their cargoes included fresh fruit. Further liner vessels with refrigeration followed and the business with South and Central America grew. Several other Swedish companies operated similar vessels, such as Transatlantic, Swedish America Line, Swedish East Asia Company, Swedish Orient Line. Johnson expanded its reefer capacity with the Rio series (100 ooo cbf reefer) in the 1950s and also modified existing vessels to increase their refrigerated and freezer capacity. They collaborated with Atlanttrafik as well as German and Norwegian reefer operators and discussions were held with Salén so they were well acquainted with reefer operations. They were already chartering in reefers to service its fruit cargoes from Argentina, and this was expensive in the high

6 For further reading see for example Collard 2014. 
season, so in 1961 they ordered their first specialized reefers. The four Valley class vessels that followed were designed in-house, and had a capacity a little under $300000 \mathrm{cbf}$, had modern cranes and could do 19 knots. In 1968, larger vessels, also referred to as Valley Class, were built and added to the fleet. These ships could do 22 knots and had a 487000 cbf capacity. Johnson's reefers were state of the art.

Johnson Line's focus was always on the liner business and similarly to other liner companies they experimented with refrigerated containers in the 1970s. Because of its involvement in the North-South trade particularly from Argentina, Johnson used refrigerated containers on their vessels. These vessels had a centralised refrigeration unit that was ducted to the insulated containers, the so-called porthole system. Johnson Line were in serious trouble around the time of the Salén bankruptcy in 1984, they pulled through, but the shipping operations later declined.

Note: a This section is mainly based on Rinman, T. 1990. The Johnson Line 1890-199o, Gothenburg: Rinman \& Lindén, pp. 88 \& 148-149. Also, Svensk Sjöfarts Tidning 1987/47 p. 14-19 \& 1987/49, p. 17-21.

The advent of containerisation, the growth of specialised reefer shipping as well as the emergence of affordable air travel all combined to end the era of the refrigerated cruise liner and these vessels were scrapped in the early seventies. Blue Star Line built six new reefers of around $500000 \mathrm{cbf}$, the new A-class, and their delivery announced the company's venture into the major fruit trades dominated by Saléns and Lauritzen-Peninsular Reefers. These larger, faster, and more technologically advanced vessels, starting with the Afric Star in 1975 were comparable to the Snow vessels built by Saléns just a few years earlier. Two of these A-class reefers were chartered by the British government for use as support vessels during the Falkland Islands conflict in 1982. Meat continued to be an important sector for Blue Star Line but the refrigerated sector expanded into the fruit market and with bananas in particular.

In 1983 the company placed a major order for four newbuildings from Harland \& Wolff of Dublin. The shipyard had built ships for Blue Star in the past and was also the birthplace of the Titanic. These vessels were the Scottish Star, Auckland Star, English Star and Canterbury Star of $465000 \mathrm{cbf}$ and were delivered 1985-86. These modern vessels were more economical than those before. They were fuel efficient, had modern handling equipment, rationally designed to maximise pallet intake and could handle a large number of containers. The vessels also had the advantage of being able to function with a smaller crew: 21 
as compared to 36 with the A-class of the seventies? ${ }^{7}$. They were successfully put to work in the fruit trades.

On the container side Blue Star Line co-operated with amongst others Hamburg Süd on its South American services. The relationship with Hamburg Süd would become particularly significant on the reefer side a few years later. The meat trades in the eighties were increasingly containerised. Blue Star Line, as ACT, competed with Cool Carriers and Seatrade for some time with meat trades from Australia to the us East Coast. This was a battle between containerised shipping and specialised reefers. The containerised services enjoyed economies of scale but the small refrigerated vessels were quicker at clearing their palletised cargoes through customs in the USA. Eventually the business became containerised. These trades carried meat from ports such as Townsville, Brisbane and Darwin to Houston, Jacksonville and especially Philadelphia. The lean grass-fed Australian beef was ideal for hamburger patties that upon delivery at the Packer Avenue Terminal in Philadelphia went directly to the grinders and from there to well-known hamburger chains.

Blue Star Line's reefer division on other hand, was separate and quite small; in 1986 it was operating 17 reefers $^{8}$. It was primarily involved in the fruit trades but also carried other cargo. Blue Star Line and Hamburg Süd merged their reefer operations and formed Star Reefers in 1989. The new joint venture was operating 25 vessels in 1991. It was also around this time that it became public knowledge that the Vestey group had serious financial problems.

It was the conjuncture of several factors that caused the downfall of the Vestey empire in the 1990s. This complex series of events can be broken down to three components. Firstly, Union International which was particularly recognised by its ownership of the massive J.H. Dewhurst butchery chain. This was a major source of the group's problems. Union International had borrowed heavily to invest in expensive high street butcheries at the time when meat retailing was switching to the supermarkets. The hysteria surrounding Mad Cow Disease only served to exacerbate the problems.

Secondly, Blue Star Line ${ }^{9}$, besides being Britain's second largest shipowner, was a holding company for diverse shipping interests where the containerised trades to the United States were the largest. This part of the business had recently been expanded by the purchase of the North American interests of

7 Tolerton 2008, p. 155-156.

8 "Cool Carriers fortsätter världsledande kylsjöfart". Svensk Sjöfarts Tidning 46/1986, pp. 35-40.

9 Owned in turn by Frederick Leyland which was the name of a shipping company acquired in 1935 . 
ACT(A) when Cunard Ellerman sold its stake to P\&O. Blue Star Line controlled Pacific Express Container Line, Booth Line and many other liner services as well as shipmanagement and its stake in Star Reefers, but profits were elusive. During the nineties Blue Star Line tried to improve its profitability by flagging out vessels and cutting costs which impacted on its British crews. The shipping interests of the Vesteys were struggling and during these years usually recorded a net loss.

The third major part of the Vestey group were its property holdings. The agricultural holdings in South America and Australia were vast and a couple of hundred thousand beef cattle ranged upon them. These solid property investments were, however, coupled with more recent speculative investments in commercial real estate, in London, and their timing was unfortunate.

So the three major parts of the Vestey empire had their own problems, to varying degrees. An additional problem that surfaced at the same time was that it became increasingly difficult for the Vestey Group to minimise its tax payments to Inland Revenue. Debts were rising and the outlook was unfavourable.

Edmund Hoyle Vestey, the Chairman of Blue Star Line, had meetings with the banks. Huge properties in Australia were sold in 1992 as a part of the plan negotiated with the banks to refinance the debts of Union International. Sir John Collins was brought onboard by the banks as Chief Executive of the Vestey Group in 1993. Until 2001, he led the process of dismantling the group in the interests of creditors. Union International could not be saved and was put into receivership in 1995. Blue Star Line, with the exception of Star Reefers, was sold to $\mathrm{P} \& \mathrm{O}$ Nedlloyd in $1998^{10}$. However, Blue Star Line acquired Hamburg Süd's part of Star Reefers. The Vestey's shipping operation was then confined to Albion Reefers as the ship owning company with six reefers ${ }^{11}$ and Star Reefers as the operating company that also included vessels on charter. Star Reefers' present-day CEO Kenneth Ross remembers the period as "biblically bad basically". Efforts were made to find another reefer operator to partner with. United Reefers, linked to the Dutch ship owner Vroon was an option that was explored but ultimately the choice settled on was NYK Reefers. However, as these matters were being discussed, the Vestey Group found a buyer for the reefer business. Christian Siem after rebuilding the ailing Swan Reefers was now set to purchase Star Reefers. This signalled the end of the Vestey's involvement in shipping. They retain substantial property holdings and some food

$10 \quad$ P\&O Nedlloyd was acquired by AP Møller-Maersk in 2006.

11 The above mentioned Scottish Star, Auckland Star, English Star and Canterbury Star as well as the slightly older Tudor Star and Trojan Star. 
interests. In the next section we will go back a few years and briefly look at Swan Reefers and then proceed to look at the recent history of Star Reefers as a part of the Siem group.

\section{Swan Reefer}

Swan Shipping was founded in 1984 by the captains Christer Jansson, Lars Ericsson and the chief engineer Bill Jansson. They purchased their first vessel, a ro-ro, by using their own homes as security. The company had been founded on the Swedish west coast but moved to Norway in the late eighties to attract capital. Bulk carriers were purchased from Klaveness and were operated in the Klaveness Bulkhandling Pool. Swan Shipping also owned reefers and ro-ro vessels that freighted forest products.

The company expanded its fleet but profits were elusive. The focus shifted to reefers. Swan Reefer was formed in 1997 with Actinor and Swan Shipping as the main owners. Actinor, besides its other interests, owned four reefers that were bareboat chartered to Del Monte and Lauritzen. Swan Shipping had five reefers at the time that Swan Reefer was formed. A tenth reefer was purchased from Chilean CAV and after a successful share emission another eight from Irgens Larsen. The rapid expansion coincided with a declining market and mounting losses with the result that the company's share price dropped sharply. Ugland began buying into the company and efforts were made to reduce costs. In 1999 Swan Shipping sold its share of the company leaving Ugland and Actinor as the largest owners.

Swan Reefer, as with other Norwegian-based ventures in the reefer market, was focused on ship owning as an investment and not as a commercial shipping operation. Most of Swan's vessels were operated in the Cool Carriers and Lauritzen pools. The company struggled and its situation became precarious when banks and investors began to lose faith. A new owner was sought, and in December 2000 it was announced that Christian Siem, of Siem Industries, was buying in. Siem was well known in shipping circles as a contrarian investor with the ability to turn things around. In order to ensure good returns, Swan needed a commercial operation. This meant that more ships were required as well as the know-how to operate them. Therefore, it was speculated that an additional acquisition was in the pipeline. 


\section{3}

\section{Star Reefers}

The reinvigorated Swan Reefer, led by Christian Siem, acquired Albion Reefers in 2001 for USD 35 million, completing the Vesteys' exit from shipping. For this relatively low price, Siem gained six reefers, a first class brand with deep customer relationships, and the management and marketing expertise required to operate his growing fleet. Swan Reefer was renamed Star Reefers the operations were placed in the Star Reefers London office. Apprehensions at Star that Siem was a speculative investor proved to be unfounded; Siem was in for the long haul.

Discussions of Star Reefers forming a joint-venture with NYK Reefers were already underway when Siem entered the scene. Consolidation was considered to be a sound strategy in the face of a difficult market. And NYK Reefers, from Star's perspective, was seen as a suitable business partner. Both companies had similar ships and customers. The business idea was also similar; both companies chartered out tonnage to the major fruit companies. And both companies were generally conservative long-term players in the industry; on paper it seemed like a good match.

A joint pool agreement was reached in late 2001 between Siem's Star Reefers and NYK. This was the start of NYK Star Reefers, a joint-venture that although short-lived, was seen as a major industry consolidation at the time. NYK Star Reefers operated seventy-four ships and was the second largest player in the industry; only LauritzenCool, also a consolidation, was larger.

Aage Thoen headed up the new operation and Kevin Harding, long-time manager at Star, continued in a senior capacity. On the NYK side, Fumiya Aoki was in charge. The office was a combined operation and people were employed by either NYK or Star and in a similar fashion the vessels belonged to one company or the other. Managing the joint-venture turned out to be difficult, each side prioritised its own interests and personalities were also a factor. There was a perception from NYK that their interests were coming off second best so in an effort to remedy this they recruited Lars Rutberg from LauritzenCool to oversee the operation. This move was perceived by managers at Star Reefers as confrontational. Star Reefers also had former Swan Reefer vessels still in the LauritzenCool pool and wanted to bring them over to the NYK Star Reefer Pool. Both NYK and Star had to agree on the terms placed on vessels entering the pool, and in this case, NYK effectively stopped the move. It later surfaced that NYK were already in talks with LauritzenCool. Later, when these bore fruit, Star Reefers was offered a role in NYK's new operation on terms that Star, however, would not accept. The joint-venture was terminated in late 2003 and the two companies went their separate ways. In the same year, Laskaridis made an 
unsolicited bid for Star Reefers, offering 7om USD and taking over 121m USD in debt. However, the offer was declined, possibly because of a promising market outlook.

Star Reefers operated 36 reefers in 2004 and around half of these were owned and the remainder were chartered in. The market boomed, rates on the spot market were, for larger vessels such as those operated by Star, up $27 \%$ from the year before, and were the best since 1997. Fixed twelve month charters were similarly climbing and the general demand for shipping assisted in fixing backhaul cargo (e.g. second-hand cars).

The Japanese ship owning company Nissen Kaiun was a key partner for Star Reefers. The general modus operandi that emerged over the years was that Nissen built new vessels at the Shikoku Yard and chartered them to Star Reefers who in turn chartered them out to the major fruit companies. After a number years Star purchased the vessels, sold or scrapped its old ones, and Nissen built new ones. In 2004 Star Reefers entered into 10 year time-charters for the first of what was eventually to become the 12 newbuildings of the Star class.

Deliveries of these modern and large (615 0oo cbf) vessels commenced in 2006 and were profitably chartered out in batches of four to major fruit companies. Star First was the first of the twelve and its name is something of a play on words: it's the first vessel of the class, and all twelve begin rather than end with the word 'Star', as had been the company's practice since the 1920s. The Star class vessels are the largest investment in reefer newbuildings so far in the $21^{\text {st }}$ century. They ensure that Star Reefers can supply quality tonnage to the market and to the banana companies in particular. The vessels have a large reefercontainer capacity, modern handling equipment and are more fuel efficient than older vessels. Star Reefers successively purchased older vessels in its operation including the Caesar reefer vessels from Oetker, Polar class from M PC, and the $\mathrm{C}$ class from Nissen. Star Reefers also developed an in-house shipmanagement subsidiary in Gdynia, Poland starting in 2006. The technical management of all of their owned vessels was eventually transferred to this operation.

In the booming market until 2008, Star Reefers was able to fix most of its fleet each year on timecharters at profitable rates and the newbuildings had long-term arrangements in place. The small portion of the fleet that traded on the volatile spot market could take advantage of the usually high rates that prevailed at the time. Russia had emerged as a major destination for specialised reefer cargoes. As a consequence, Star had several of its vessels ice-strengthened, which was a prerequisite to reach St Petersburg in the winter months. Five vessels were placed on long-term time charter with the Russian fruit importer Sunway and in 2008 also to the Joint Fruit Company. 


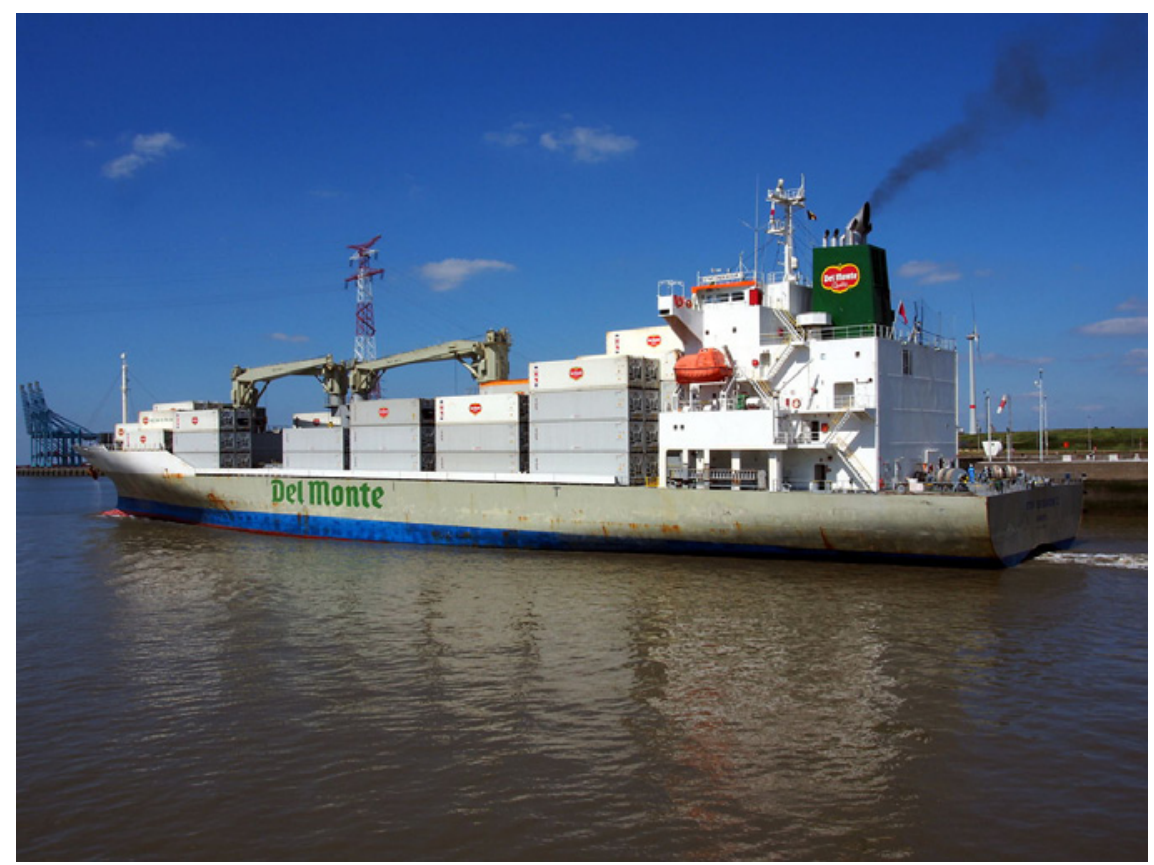

FIGURE 20 The Star First class is the largest series of reefers built in the $21^{\text {st }}$ century. Pictured is the Star Endeavour, here on charter to Del Monte, leaving Antwerp in 2012 PHOTO: ALFVANBEEM

However, 2008 was also the year that the market started to slide as the global recession impacted. Scrapping prices were still high and many owners of older vessels took advantage of this. Star didn't take this opportunity and their vessels continued to trade profitably for a time. Star managed to record a profit in 2009 despite the market downturn due to its previously negotiated time charters. The recession also coincided with poor fruit harvests in Central America, poor squid catches in the South Atlantic, reduced poultry trade between the USA and Russia as well as high bunker prices. Reefer cargo rates were also driven down as a result of container line overcapacity. The combination of reduced supply, demand, financing and increased cost and competition from container lines caused the spot market to plummet to levels well below that necessary to cover operating expenses. Russian fruit importers encountered difficulties and returned their chartered vessels to Star which in turn exposed the vessels to the spot market with losses as a result. Star was eventually able to re-establish its connection to this trade with a contract to Banex that provided for a weekly service between Ecuador and St Petersburg. 
Star's fleet reached a total of 46 reefers but the state of the market had forced several of them into lay-up. Shippers were avoiding fixing their tonnage requirements on timecharters and instead took advantage of the low prices that prevailed in the spot market. Star began scrapping older vessels when scrapping prices improved in 2011. Some vessels were also sold. Star was able to return to a modest level of profitability when the market improved in 2013. The "C" class vessels Caribbean Star, Costa Rican Star, Cote d'Ivoirian Star, and Colombian Star were lengthened and had new cranes fitted in 2013 and 2014. The four rejuvenated vessels were chartered to Africa Express Line.

Siem Industries, the holding company, diversified its shipping interests into the transport of automobiles with Siem Car Carriers. Two Star First vessels were purchased from Nissen in 2015 and this was followed by an agreement to timecharter two newbuildings from the same owner and the same Shikoku Shipyard. These new ships, the Star Spirit and the Star Courage, have a capacity of $650000 \mathrm{cbf}$ under deck and can carry approximately 300 refrigerated containers ${ }^{12}$. As of 2016 Star Reefers operates 28 vessels mainly in the banana trade, and their average age is about 15 years.

\section{Summary}

Blue Star Line was similarly to the Japanese shipping companies a liner operation that expanded into the the specialized reefer trades as a complement to their liner business. Also, similar to NYK, Blue Star Line could not integrate the specialized reefer operations into the liner business, due to operational differences. The specialized reefer division came to live a fairly independent life, which consolidated with Hamburg Süd into Star Reefers in the late 1980s to increase their market presence. Due to the problems in the Vestey group Star Reefers declined during the 199os and similarly to Lauritzen they knew that if they couldn't consolidate with another actor they were doomed to a slow decline. At this point in time NYK Reefer had established their main office in London and it was agreed to start a joint operation. The two parties fit perfectly, both being liner companies. However, before the joint venture materialized, Star Reefers was purchased by the Swan Reefer group led by the shipping investor Christian Siem in 2001. At first this was perceived by the market as a predatory investment basically for the hard assets, and this was most probably due to the subjective perception of Christian Siem as an outsider who also had

12 Press Release of Siem Shipping Inc. 10 January 2016. Report for the first nine months and third quarter 2016. 
done good M\&As in the past. NYK Reefer perceived the collaboration to be biased and looked for an alternative partner. Star Reefers has after 2003 expanded their fleet with newbuildings in collaboration with Nissen, which is the largest newbuilding programme in the first decade of the 2000s. Around 2010, Star's fleet peaked at 46 vessels but declined to 28 vessels as of 2016. Star Reefers discursively position itself as a modern, high-class partner to the fruit companies, and the perception of Christian Siem as a short-term opportunist is gone. 


\section{Laskaridis and the Hamburg Reefer Cluster}

The Laskaridis family is today a major player in shipping. In contrast to many of the other players on the reefer scene, the Laskaridis family has since the 1950 s been involved in fishing business. Constantine Laskaridis, after studying ichtyology and applied fishing in Germany, started to work in the Greek Ministry of Economy. Simultaneously, he was involved in running the ship Evridiki, the first Greek fishing vessel to have space for deep-freezing fish ${ }^{1}$. In 1955, he left his job in the Ministry and dedicated himself fully to private business. Together with Dinos Doziadis, he created the company Zephyros, which was involved in ocean fishing, primarily outside West Africa, with five vessels equipped with deep-freeze systems. Some of the respondents have even said that Constantine was the first Greek who went fishing outside West Africa, an area which supplied fish similar to those of the Mediterranean, but in higher quantities. In 1967, Constantine Laskaridis started an independent business, initially with the fishing vessel Kyknos I and later with more ships. The fish was transshipped to reefer vessels, which took the fish to the areas of consumption.

From the mid 1970s, his sons Thanassis and Panos joined the company, after completing their studies in Germany in the field of engineering. Similarly to the description of the Japanese fishing companies, this period witnessed the implementation of the 200 miles Exclusive Economic Zone which hampered Greek fishing interests. The Laskaridis brothers started to work as brokers for chartering reefer ships. From the 1970s the family specialized in the transport of fish, especially by means of transshipment in the ocean.

In the end of the 1970s, the Laskaridis group bought three Japanese fish carriers, with exceptionally large tanks, which created the conditions for a lucrative combination of fish transport and bunker supply to fishing fleets. In the early 1980s, the Nigerian fish importer Primlaks was struck by trouble, and Laskaridis together with Seatrade bought half of Primlaks' fleet of 16 ships each. As fish brokers who needed transport capacity for fish, the Laskaridis family had done quite some business with the International Reefer pool based in Hamburg, which had a large fleet of smaller reefers at the time.

1 For overviews of the history of Greek merchant shipping and the presentation of major Greek shipping families, see Harlaftis, G. 1996. A History of Greek-Owned Shipping. The Making of an International Tramp Fleet, 1830 to the present day, London: Routledge. A brief description of the Laskaridis family's shipping interest is available in Theotokas, I. and Harlaftis, G. 2009. Leadership in World Shipping: Greek Family Firms in International Business, London: Palgrave Macmillan. 
In 1982-1983, Joachim von Reiche, the manager of the International Reefer pool decided that he would like to take on new challenges somewhere else and was therefore looking for alternatives. A particularly interesting alternative was to join the Laskaridis group, which was attractive because of it being a family business, with quick decision making, and an unconventional way of working. Laskaridis who had experience with International Reefer and von Reiche gladly invited him to join. When von Reiche approached his nearest colleagues in the International Reefer pool, they also expressed interest in joining Laskaridis if there was room for them. Given this potenial migration of the managers in the pool, those with know-how, in comparison to the various owners, some owners started the perceive the risk of a brain drain, which would seriously hamper the future prospects of International Reefer. As a result, the German group Harmstorf and the Swiss Alpina group was willing to join von Reiche and Laskaridis.

This was the start of a new pool called Alpha Reefer Transport. The name Alpha came from A as in Alpina, L as in Laskaridis, and Ha has in Harmstorf. Laskaridis also put tonnage into the pool, and in total the fleet was 12 ships of a size of up to $200000 \mathrm{cbf}$. Apart from Alpha, another organization was formed - Frigoship Chartering in Hamburg. This was the exclusive broker of the Alpha pool, and thereby the organization with contacts to the market. In short, Frigoship stood for chartering while Alpha was handling the operation. Also, Frigoship has only one owner which is Laskaridis, while Alpha has several partners.

The Alpha pool grew with new pool members. A Spanish company joined, as well as some banks which had unwillingly become reefer owners. Laskaridis and the Alpha pool was successful in securing tonnage from post-Soviet owners such as Klaipeda, HSC Agency, and Yugreftransport. The other successful player in securing post-Soviet tonnage was Eastwind. Already during the Soviet era, the Laskaridis group had good contacts with Soviet reefer owners, providing various services to the Soviet fleet. The Soviet reefer fleet was before the demise of the Soviet Union exclusively working within the Soviet sphere, which meant that they had basically no experience of competing on an open market, which was very obvious in some early deals where the rumours go that the post-Soviet reefer owners were "taken to the cleaners". From the reefer owners' point of view, joining with Alpha was a way to learn how to operate on a global reefer market. From Alpha's perspective, it was good to increase the number of ships in the pool, to get a broader offering to customers, as well as increasing the income of the pool. Alpha's business was familiar to the new post-Soviet companies, since much was focused around fish. The ex-Soviet vessels were particularly good for transshipment of fish - this was a Soviet specialty. Also, the U.S. started to export chicken legs to Russia, called Bush legs. In 
one year they could export as much as 1.2 million tonnes. The ex-Soviet ships were excellent for carrying deep frozen poultry. The ships also had high iceclass which meant that they could transport the cargo to St Petersburg also during winters. This business has been called a "gold mine". But at the same time, the ships were uneconomical in that they consumed lot of bunkers - the transition to a market economy made some hidden inefficiencies painfully visible. Gradually, some of the post-Soviet ships were scrapped.

However, this boost in tonnage led to Alpha Reefer Transport reaching its peak in controlled tonnage in the early 1990s: 55 ships. In the 199os and first decade of the 200os, the small ships have gradually left the pool since they are not economically viable. This fleet development coincided with the general trend in the second half of the 2oth century towards larger reefers. As of 2015, the smallest ships are of a size of $150000 \mathrm{cbf}$. These ships have proven that fairly small ships can still be economically profitable, if they are employed on special trades, for example servicing ports that can only receive ships of a certain size.

Apart from Alpha Reefer Transport, Laskaridis also owned larger ships of about $400000 \mathrm{cbf}$ which were employed outside the pool, often in the Seatrade pool. Six ships were built in Japan in the end of the 1980 . One reason for building ships in Japan, apart from the high quality of the ships, was that Laskaridis was involved with a Japanese partner in the transportation of squid, and it was favourable to have Japanese built ship for the operation. Also, Laskaridis was very active on the second hand market buying tonnage at good prices. For example, after the Saléninvest bankruptcy, Laskaridis bought a ship from the bank, and the investment cost was recovered in less than a year. It is well agreed by respondents that Laskaridis has a skill to buy tonnage at the bottom of the market. A related skill of the group was to sell ships at the top of the market. Therefore, ships in the Laskaridis group often change owners in order for the ships to always be as profitable as possible for the group.

The trend within the Laskaridis group was an increase in controlled tonnage in the 1990s and 200os, where they gradually bought ships, from companies who were willing to exit this declining industry. In 2003, Laskaridis is said to have placed a bid on Star Reefers which was not accepted by the shareholders. A more successful example was when Maritima del Norte, an independent Spanish operator, having a fleet of eight vessels was split between Seatrade and Laskaridis. Another was when Amer decided to sell its fleet of seven ships in 2008, which were bought by Seatrade, Laskaridis, and others.

Joachim von Reiche, who had been instrumental in increasing Laskaridis impact upon the reefer markets, had in November 2009 a big retirement party, to which many reefer companies were invited. During the party owners of Lavinia and Seatrade met and said that they had to stop competing with each 
other and instead start working together. It was left to the top managers Wolfgang Zielke, who had worked together with von Reiche since the 1970s, and Yntze Buitenwerf from Seatrade to sort out the details. The managers recommended to start on a small scale, but the project escalated and soon Laskaridis wanted to put all his small ships in the pool, and the Norwegian operator Green Reefers wanted to join. The first meeting was in December, and in the beginning of May the pool was operational. It was received with great surprise in the market. The marketing office Hamburg Reefer Chartering was based in Hamburg, and Alpha carried out the operation. Frigoship gave up part of its business and handed it to Hamburg Reefer Chartering. The first two partners were Lavinia and Seatrade, but when Green Reefers joined the fleet size amounted to 110 ships comprising 27 million cbf.

With such a substantial fleet, the company had to be assured that they would not be perceived as monopolistic according to EU monopoly law. According to the consulted laywers, the share of the pool in relation to worldwide transportation was too small to have an impact. However, there is no doubt that the impact was significant in the particular segment - small reefers - that the company was operating in. Some say that the market share of Hamburg Reefer Chartering was as high as $80-90 \%$ of the world fleet in that size segment.

As with many other cooperations that we have seen in the book, Hamburg Reefer Chartering was shortlived. But according to respondents, they succeeded with one major thing. When the pool went operational, an analysis was done to see how many ships were required. It was found that only about 75$80 \%$ of the capacity was needed. Given this analysis, it was decided to scrap 20 ships, or every partner had to scrap seven ships. A special bonus was given to those who agreed to scrap their ships - if they would scrap the ship as of 1 January 2011, they were offered 500000 USD of scrapping bonus plus the fact that the ships would be part of the pool virtually until the end of June, that is getting additional earnings of a year without even having a ship in the pool. The strategy was successful, and it is quite obvious that this has impacted on the charter rates of ships in the small segment. If the partners had not joined a pool together, no such concerted effort would have been possible.

But Seatrade was uncomfortable in the relationship and decided to discontinue the joint work. As with many of the break-ups seen in this book, this can probably be attributed to a number of factors ranging from operational philosophy and money to control, power and cultural aspects. Green also decided to leave Laskaridis in 2012 and join Seatrade, forming the GreenSea pool of 48 ships.

From 2011, the former operation of Frigoship and Alpha was reactivated, starting with 24-25 ships. Laskaridis withdrew his ships from the Seatrade pool, effectively ending all connections to Seatrade, and the number of ships in the 
Alpha pool increased to 45. Limarko, formerly Klaipeda, one of the early members, is still part of the pool. HSC Agency is run by the former managing director of Klaipeda, Aveny Bich, owning a few ships. Yugreftransport, formerly from Sevastopol, are now located in St Petersburg. Agder is a Norwegian investor, with a few ships in the pool. Fairport is run by the Greek Kalimassias - a major competitor to Hamburg Reefer Chartering - who has five ships in the pool. As of 2014, Laskaridis owned 27 (reefer) vessels.

Laskaridis states that "We have a view, which we have consistently held for the last 20 years, that eventually everything that can be containerised will be containerised" 2 . This is a reason for which Lavinia is specializing on open sea transshipments, which is still a conventional reefer specialty. There is a constant risk that the need for conventional reefers doing open sea transshipments will decline. If the catch is brought to port, container lines can be used to ship the fish to the market. Furthermore, bringing the fish to port can increase the state's control over the catch, as well as possibly creating employment ashore. However, it is plausible that fishing companies would like their trawlers to remain in the fishing grounds, which means that there will be some need for transshipment. The business will therefore not die overnight, but will most probably see a gradual decline. Laskaridis said, "You could call [the reefer trade] a business in a run-off mode, but it is a slow, profitable run-off, and as things seem today we may have to re-invest in a few ships to continue servicing very specific trades" 3 .

Apart from the reefers Lavinia has interest in more than 30 bulkers, tankers for supplying bunkers to fishing fleets, and two factory trawlers. The company has thus remained in a niche of the reefer market, while building up a fleet that is unaffected by the decline in the conventional reefer market.

\section{Eimskip}

Another reefer operator with a close link to the fishing industry is Iceland's Eimskip. The company was originally founded as Eimskipafélag Íslands (Iceland Steamship Co) in 1914, thousands of Icelanders proudly purchased shares in the company that would end Iceland's reliance on Danish shipping. The first two ships, the Gullfoss and Godafoss arrived in 1915, both named after waterfalls, a tradition that has persisted ${ }^{\mathrm{a}}$. The company started sailing to America in 1917 due to the war and in 1926 the first vessel with temperature control, Brúarfoss was added to the fleet ${ }^{b}$. Shipping fish from Iceland and returning with miscellaneous cargo was the main business for many years but the company also diversified.

2 "Going in for the krill". TradeWinds 23 May 2014

3 "Going in for the krill". TradeWinds 23 May 2014 
Eimskip dramatically expanded in the 2000 s, by 2007 they operated 50 ships and was the largest cold-storage provider in the world ${ }^{c}$. However, the company crashed as a result of Iceland's banking crisis ${ }^{\text {d }}$, but there were also other factors, and recorded a net loss of 645 million Euro for the year ended 31 October $2008^{\mathrm{e}}$.

Creditors took control over the company, it was reconstructed and the cold-storage business sold. The shipping business remained and returned to a North Atlantic focus and has been a profitable niche player in the reefer market ever since. In later years they have acquired several companies with a focus on freight forwarding but have also invested in cold stores and harbour infrastructuref ${ }^{f}$. In 2018 they had a weekly service from Iceland to Portland Maine also calling on Halifax and Newfoundland, several lines connecting Iceland to Northern Europe, many calling on the Faeroe Islands, and also a line servicing ports in Norway and continuing on to Murmansk. Fish and seafood was the most important cargo. Besides three ferries Eimskip operated 19 fairly small vessels, 10 owned and 9 chartered. Some of these are specialized reefers and the remainder are container vessels with reefer capacityg.

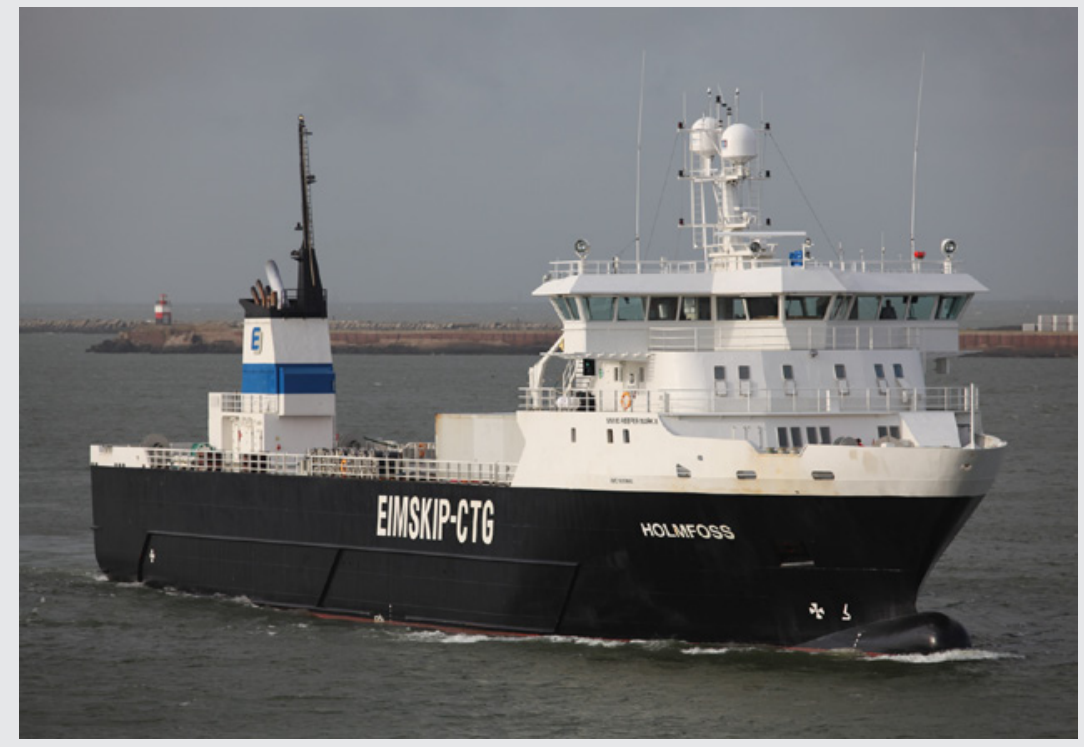

FIGURE 21 Small reefers like the Holmfoss connect Norway's fishing ports and Murmansk to the UK and the Continent. This vessel was delivered in 2008 and can handle different temperatures in its five holds. Eighty metres long, it can carry $28 \mathrm{FEU}$ containers, with reefer plugs, and is rated to operate in one metre thick ice

PHOTO: JOOST J BAKKER 
Notes: a Jóhannesson, G.T. 2013. The History of Iceland, Greenwood: Santa Barbara, p. 96; b Eimskip webpage <http://edit.eimskip.is/EN/about/history/default.html>; c Hf. Eimskipafélag Íslands Annual Report 2007, p. 6; d On the Icelandic banking crisis see for example Boyes, R. 2009. Meltdown Iceland, London: Bloomsbury. For a perspective by a central figure connected to the crisis and to Eimskip see Bjorgolfsson T. 2014. Billions to Bust - and Back, London: Profile Books; e Hf. Eimskipafélag Íslands Annual Report 2007, p. 5; Eimskip Annual Report 2017 p. 2; g Eimskip webpage <https://www.eimskip.com>

Hamburg Süd, a short version of the original name Hamburg Südamerikanische Dampfschifffahrts-Gesellshaft, is a liner operator that since 1871 has been focusing on North-South trades. While originally owned by a group of merchant houses, the Oetker family acquired an interest in the company in 1936. Hamburg Süd was a major operation and boasted a fleet of 50 ships in 1939. Both world wars led to a complete loss of the fleet, but from 1951 the liner service between Europe and the South American East Coast was resumed. In 1952, the business expanded to tramp shipping. During the 1950s, Hamburg Süd started to develop its tramp reefer business. In the early 1950s they chartered tonnage, and later bought reefer vessels. The 1950s was also, according to respondents, the decade when the small tramp reefers started to appear on the market, with players such as Gustaf Erikson. This entry into the reefer segment was, however, not their first experience with carrying reefer cargo, their liner vessels had also carried reefer cargo. In the 196os a typical liner vessel in the Hamburg Süd fleet would have a cargo hold for refrigerated goods of about 150 000 to $200000 \mathrm{cbf}$. It has been told that such liner vessels loaded mainly meat in Argentina and orange concentrate in Brazil on the way to the us or Europe.

Hamburg Süd saw the potential of the reefer market, which was deemed much more attractive than the general cargo segment which saw a slump in the latter half of the 1950s. Hamburg Süd also followed the growing import of bananas closely, where per capita consumption increased rapidly. The company wanted part of this high-growth segment. Also, Hamburg Süd was now part of the Oetker conglomerate, which had significant financial resources, and were willing to invest in tonnage, not only because of the interest in shipping, but also because of the attractive tax conditions associated with ship investment.

In 1960, Hamburg Süd had 16 reefers from about 120 ooo cbf to $230000 \mathrm{cbf}$. Although these ships were already big compared to the small tonnage that appeared in the 1950s on the tramp market, Hamburg Süd envied JLauritzen's red painted ship of $270000 \mathrm{cbf}$. In the early half of the 1960 s a new series was built 
with vessels of the size of 300 ooo cbf, and in 1968 vessels of 420 ooo cbf were built. We can therefore see an increase in ship size, and representatives of Hamburg Süd felt they were a major part of the trend of building larger reefer tonnage. The Polar class ships had an operating speed at banana draught of 23.5 knots and had a capacity of about 420 ooo cbf. The Polar ships were chartered out to Salén for banana trades. The ships of $300000 \mathrm{cbf}$ were on a fiveyear timecharter to Standard Fruit. About 50\% of Hamburg Süd's reefer division was dedicated to carrying bananas. Part of the fleet was also servicing fruit trades from Chile, Argentina, and New Zealand. The smaller ships were chartered to German fruit importers on a yearly basis. The ships were also doing tramp business, voyage charters, for example exporting chicken from the Us to Europe. For the ships around $200000 \mathrm{cbf}$, they were often chartered to Salén for nine months, and then the ship went to drydock when it was redelivered in June/July, and then employed on the spot market during the Northern summer. The reason why many ships were fixed to Salén was because they offered the best rates - which is an indication that they could use their extensive fleet and network to reach synergies.

Hamburg Süd were also agents for a fleet of 18 ships, from $30000 \mathrm{cbf}$ up to 60 ooo cbf. These are very small reefers that sailed the Norwegian coast carrying fish. In that time, small ships could go as far as South America, into the Great Lakes, to the Middle East, and to New Zealand. The margins were there, the income was good and labour costs and bunkers were cheap. Times were good in the reefer business, which was of course a reason for small tramp reefers being developed. They were also trading between India and the Gulf ports with bananas and livestock. Another cargo was blueberries from Poland and Sweden to Germany.

There were some synergies between the reefer and the liners. In contrast to for example NYK which had reefers operating North-South and liners EastWest, both the reefers and liners potentially operated on the North-South routes. At times, when the liner vessels did not have enough capacity to carry all the cold cargo from South to North, they contacted the reefer department and asked for additional tonnage, which was either supplied from the in-house fleet, or more commonly chartered in from the open market. This would have been more difficult if Hamburg Süd didn't have its own presence in this market. Sometimes, the liner departments used reefers as dry cargo ships, carrying coffee and other non-refrigerated cargo. Since the reefer division operated on the global market, their chartering staff also learned about profitable refrigerated cargo that could be carried by the liner vessels, for example potatoes from Europe to South America. In that way, the liner department could get a better 
yield on the voyage from North to South. However, the fact remained that the liner and reefer divisions had different mindsets. One was engaged in regular trade with a timetable and the other was more oriented towards the spot market. The liner division was working with smaller quantities and the reefer division with larger quantities of cargo: "in the liner operation you have 100 tons here and there. In reefers we are thinking 10000 tons of bananas, 5000 tons of meat".

The 1960s were very good for the reefer division of Hamburg Süd, but the market suffered a downturn at the end of the decade. For the group this was compensated with better earnings on the liner side. As a response to the decline in the reefer market, Hamburg Süd started to sell its smaller reefers, those smaller than $200000 \mathrm{cbf}$. This decision was partly due to the slump in the reefer market and partly due to the fact that containerization started for Hamburg Süd in the late 196os. It started out in Australia with Columbus Line, an affiliated company, carrying meat from Australia to the Us. Financial means had to be focused on the investment into container ships and containers. Although, the containerization would lead to more reefer capacity on the new container vessels than in the previous liner vessels, it redirected attention away from conventional reefers, especially smaller reefers.

While Hamburg Süd had been agents for the fleet of smaller reefers, in 1970, Joachim von Reiche was asked to be the manager of a pool of small reefers, called International Reefer. This pool was concentrated on marketing a common fleet of small reefers from 60 ooo to 130 ooo cbf, supplied by 12 shipowners. The idea was to get a broader coverage of the market by working together. The pool also functioned as an information hub, where the owners could get information about the present and potential futures of the reefer market. This information function was already present at Hamburg Süd when they were handling the small reefers but was now set up as a stand-alone unit. This could be compared to the Leonina pool of Cool Carriers, which was also an information hub. Furthermore, by employing the ships in a pool, each of the participating owners didn't require in-house chartering personnel - but could outsource that to the pool, cutting labour costs. However, the owners were still in charge of the operation of their ships. Like other pools, the earnings from the pool were shared between the partners given the ships capacity, speed, fuel consumption and any extra frills, such as cargo handling gear, etc. From the beginning, this pool had 18 ships, but it grew to a maximum of 35 . 


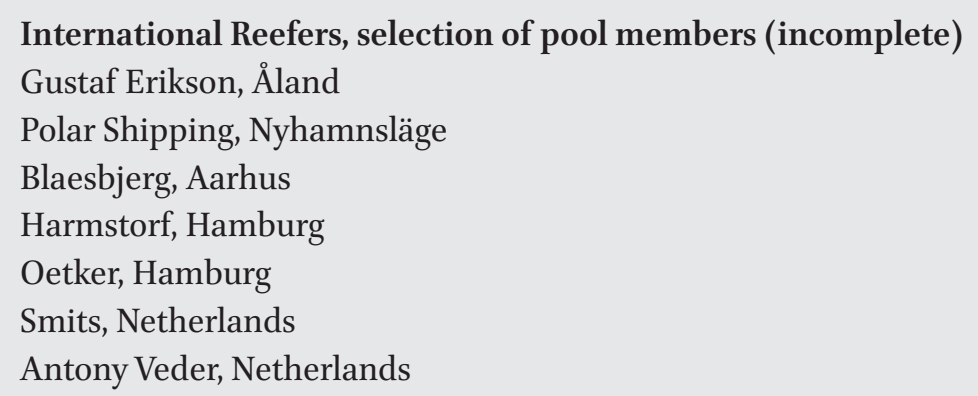

In 1974, Wolfgang Zielke started to work at Hamburg Süd. He recalls that these were the glorious days for reefer ships. Germany operated a substantial fleet, with companies such as Ahrenkiel, Bruns, Ianka, Luhmann, Horn, and the International Reefer pool. The German-owned ships were often built in Germany at shipyards such as Sietas, HDw Hamburg, and Blohm \& Voss.

In 1979, Hamburg Süd took delivery of two reefers of 480 ooo cbf. They were chartered to Castle and Cook, Dole, but just after two years, the collaboration was discontinued. Rather than collaborating with Hamburg Süd, Castle and Cook, Dole acquired the reefer fleet of Bruns - another German reefer player - of about 10 ships. In the 1970s and early 1980s, Hamburg Süd had a fleet of about 15 owned and chartered reefers. The large Polar ships were still on charter to Salén. Some smaller ships were left in the fleet and employed in the International Reefer pool. However, it was clear that Hamburg Süd was no longer interested in building their reefer fleet. Rather, the situation was one of gradual decline. The Polar ships were sold and chartered back for a few years. At that time, Joachim von Reiche from International Reefer had started to work together with Laskaridis and was interested in making Hamburg Süd join with Laskaridis. However, in 1986, Hamburg Süd decided to collaborate with Star Reefers and moved all the chartering operation for the larger ships to London.

\section{$2 \quad$ Summary}

Similarly to SKG (Seatrade), Hamburg Süd experienced a downturn of the general cargo markets in the late 1950s and also saw that the import of bananas to Germany was increasing significantly. Therefore, they decided to invest in reefers. In contrast to other liner companies such as Blue Star Line and NYK, Hamburg Süd's lines were North-South which made it possible to create synergies between the liner and specialized reefer segment. They subjectively perceived the larger reefers to be more prestigious, which was a reason that they 
continually built larger ships. Smaller ships were spun out into International Reefers in 1970. Due to the focus on the liner operation, Hamburg Süd's specialized reefer operation gradually declined and in 1986 a collaboration was made with Star Reefers which moved the operation of larger ships to London.

Laskaridis started out as a fishing company but expanded to be a reefer operator focused on fish transports in the 1970s. Similarly to Seatrade, and in contrast to Lauritzen and Saléns, Laskaridis was focusing on fish transports. To gain more market knowledge and customer connections Laskaridis worked with the Hamburg cluster, similar to how other companies have approached the Stockholm cluster to get competent personnel. With a base in Hamburg, Laskaridis started the Alpha pool in the early 1980s. Given Laskaridis' sense for business, seen as fast and unconventional, the company managed to get their hands on post-Soviet tonnage in the early 199os. Given the increased competition and lower profitability in the 199os the smaller ships were phased out. Given Laskaridis' willingness and ability to invest, the company was able to buy tonnage from distressed owners and banks. A large-scale collaboration was Hamburg Reefer Chartering which had a fleet of over 100 ships. However, it is difficult to collaborate and in 2011 Laskaridis left the pool and recommenced an independent operation. Laskaridis, similar to other Greek owners, has been subjectively understood, by the largest players such as Lauritzen and Cool Carriers, as a second-tier player, operating with old tonnage on secondtier trades. Still, it must be said that profitability does not always follow pride, and Laskaridis is seen by many to have been highly profitable over the years, in contrast to Lauritzen and Cool Carriers. 


\section{PART 3}

\section{Container Lines and Shippers}


As we described in the introductory chapter, there are a variety of actors in the cold chain. All these actors have had an impact on the historical development of the independent reefer operators. In this part, we describe two kinds of actors. First, we describe container lines, using the example of Maersk. Liner companies have always been a major competitor to the independent reefer operators. We describe Maersk in order to see the reefer industry from another perspective to understand the independent reefer operators' competitors. Second, we describe fruit companies and marketing boards which have been important customers of the independent reefer operators. 


\section{The Traditional Liner Companies and the Container Lines}

In the 1800 s maritime trade underwent a revolution and much can be explained by four factors: steam engines, iron hulls, screw propellers, and a deep sea cable network. During the second half of the 19th century, the contours of the new maritime market were clearly visible. There were passenger liners which on regular services transported mail and passengers between North America, Europe and the Far East. There were cargo liners which transported cargo and some passengers between developed and imperial markets. And there was tramp shipping which carried spot cargoes, often bulk cargoes, such as coal and grain ${ }^{1}$. While tramp ships had a long history, the liner companies were a product of the transport revolution in shipping.

The passenger liners were the fastest, operating at a speed of 16-25 knots. They were symbols of national engineering prowess. The passenger liners were fitted for passengers, obviously, but also for some cargo. The companies in this business were for example Cunard, White Star, North German Lloyd and Holland America Line.

The cargo liners were not as fast, often operating at a speed of about 12 knots, but they were highly flexible. They had many decks to allow for loading and discharging in several ports, and compartments for specialty cargo, such as refrigerated goods. They could carry some passengers, but towards the end of the 19th century, most of the passengers were carried by passenger liners. The liner trades loaded and discharged in several ports and the stowing and discharging operations were complicated and time-consuming. The cargo could come in bags, bales, cases, and casks.

Soon after the birth of the cargo liners, in the 1870s, the conference system was developed. Major British companies such as $\mathrm{P} \& \mathrm{O}$, Alfred Holt and Glen Line, realized that competition was forcing prices down to levels that did not cover their costs. To keep prices up there was a need to collaborate. The first conference was that between the United Kingdom and Calcutta, formed in 1875. The rates were set, the number of sailings limited, and the participant companies should not grant preferences or concessions to shippers. This was not appreciated amongst the shippers. To understand the independent reefer

1 Based on Stopford 2009, p. 23-32, 35-41, and chapter 13. 
operators, it is important to understand the control that conferences had on maritime trade, and the alternative that the independent reefer operators and other tramp shipping companies could provide to shippers. However, conferences continued to develop and by the 1950 s there were 360 liner conferences in the deep-sea trades, which regulated sailings and freight rates. Each had between two and 40 members. Examples of the then dominating liner companies in the 1950s were P\&O, Blue Funnel, and Hamburg Süd.

In the 1960s, containerization had a great impact on the liner companies. The labour-intensive stowing and discharging of standardized containers could be mechanized. Many cargo liners were very inefficient spending up to $50 \%$ of their time in port. Containerization also led to additional benefits such as the reduction of pilferage. And the cargo could more easily be re-loaded onto rail or barge with less delay. Apart from containerization, the traditional liners were affected by the development of airlines which took over passenger and mail trades. Also, as colonies gained independence, the liner companies lost their privileged position in many of its core trades. The passenger liners dissappeared within a decade, or were converted to cruise ships, and the cargo liners were gradually replaced by container vessels and specialty ships, such as reefers. Similarly to the independent reefer operators, the liner companies thought that containerization might be too inflexible and looked for solutions based on palletisation and the use of ro-ro vessels.

The first container ships purpose-built to transport refrigerated containers were built by OCL and ACT in 1969. They had a capacity of $450 \mathrm{TEU}$ reefer containers. In 1970 the Sydney Express was delivered to Hapag-Lloyd and the Columbus New Zealand to HSDG in 1971. Centralized cooling units ducted cold air to insulated, porthole containers. ${ }^{2}$

The market changes ushered in by containerization, in combination with the penetration of market competition, led to a weakening of the conference system. The conference system was gradually changed to a more open system with stabilization agreements and alliances.

The container lines are the new generation of liner companies, such as $\mathrm{P} \& \mathrm{O}$, Blue Star Line, Hamburg Süd, and Johnson Line which regularly carried refrigerated cargo. While containerization of dry cargo was difficult in itself, containerization of reefer cargo was much more demanding. Furthermore, containerization required and continues to require significant investments

2 Wijnolst and Wergeland 2009, p. 288. 
TABLE 13 World's largest container ship fleets (TEU)

Container line

Maersk Line

Mediterranean Shipping Company

CMA CGM

cosco Shipping

Evergreen

Hapag-Lloyd

APL

China Shipping (CSCL)

Hanjin Shipping

MOL
Capacity (TEU)

$2.62 \mathrm{~m}$

$2.19 \mathrm{~m}$

$1.35 \mathrm{~m}$

$0.72 \mathrm{~m}$

$0.7 \mathrm{om}$

o.64m

o.6om

$0.57 \mathrm{~m}$

$0.56 \mathrm{~m}$

$0.51 \mathrm{~m}$

Source: From Manners-Bell, J. 2014. Global Logistics Strategies, London: Kogan Page.

and the industry is now the most consolidated section of shipping ${ }^{3}$. The world's largest players in 2012 are listed in table 13.

If we now turn to the reefer capacity of the container lines (see table 14), we see that Maersk is quite naturally the largest player. However, what is surprising is that Maersk has more than three times the container capacity, in terms of reefer containers, of the second largest container line MSC. If we consider the number of reefer plugs in the north-south trade, Maersk was the biggest player in 2016 with 103000 plugs, followed by Hamburg Süd with 87000 and Mediterranean Shipping Co. with $85000^{4}$.

As has been mentioned in the second chapter, the container lines overtook the specialized carriers in terms of reefer capacity in 1997. In 2013, as table 14 shows, the capacity of the container lines was $74 \%$ of the total global reefer capacity, and it is expected that in 2019 , the share will reach $83 \% 0^{5}$. The trend reflects the strategic intent of the container lines to grow their reefer business, due to the rates in the reefer business and that attracting reefer cargo addresses overcapacity. Furthermore, the growth is possible both because of growing

3 See for example Poulsen, R.T. 2007. Liner shipping and Technological Innovation: Ostasiat and the Container Revolution, 1963-75, Scandinavian Economic History Review, 55: 83-100.

4 "Reefer ships forecast to lose share to container vessels" Journal of Commerce 31 January 2016. $<$ http://www.joc.com/maritime-news/container-lines/reefer-ships-bucked-trend-2015-dy namar-reports_20160131.html>.

5 "A Perspective on Refrigerated Container Trade Growth". GeP Mind. <https://www.gep.com/ mind/blog/perspective-refrigerated-container-trade-growth>. 


\section{Container line}

Maersk Line

Mediterranean Shipping Company

CMA CGM

Hamburg Süd

APL

CSAV

Hapag-Lloyd

Evergreen

MOL

Hanjin

Other container lines

Specialized reefers
Reefer capacity market share

(available equipment)

a Drewry Reefer Shipping Market Review and Forecast, Annual Report, 2013/14, retrieved from Duggan, W.C. "Carrier perspective on Refrigerated Shipping", Maersk Line. <http://agtrans. org/wp-content/uploads/2014/07/william-dugan-2014.pdf>.

trade flows and because of the withdrawal of specialized reefer capacity. In 2016, container lines were positive about the prospects in the reefer trades. Nick Fafoutis, chief commercial officer at the French container lines CMA CGM, believes that container carriers will continue to capture market share at the expense of specialized carriers, but, he claims that "Adversaries can become complementary partners" suggesting that the increasing market demand in both emerging and developed economies is positive for both container lines and specialized carriers ${ }^{6}$. Not only do the container lines grow at the expense of specialized carriers. They also gradually move into produce that have traditionally been carried by specialized reefers, for example bananas. In 2015, the container lines carried $55 \%$ of the total volume of bananas compared with $44 \%$ in $2012^{7}$.

6 “Container lines' reefer investments reap new services". Journal of Commerce 9 July 2016. <http://www.joc.com/international-logistics/cool-cargoes/reefer-investments-ongoing-con tainer-carriers_20160709.html>.

7 <https://theloadstar.co.uk/coolstar/container-lines-going-bananas-to-grab-a-bit-more-mar ket-share/>. 
A full description of the container lines' strategies in the reefer trades is outside the scope of this book. However, we will briefly describe the history, focusing on the reefer business, of Maersk Line, which is not only the largest container line, but also the largest in terms of reefer plugs and reefer equipment.

Maersk is the largest player in the market for carrying refrigerated cargo ${ }^{8}$. Starting out as a steamship owner in the late 19th century, the family business grew to be one of the world leaders in containerized liner shipping. Maersk Line developed a line from the us East and West coast to Asia in the late 1920s, and during the 1950 and 1960 added ports in the North Atlantic, West Africa, the Middle East and Europe.

In the 1960s, similarly to other liner companies, Maersk had to decide how to face the growing challenge of containerization of cargo. When the containerization challenge appeared, Maersk had already taken a decision to move away from break-bulk and unitize cargo around the pallet. By the end of the 1960s many competitors, such as Sea-Land, APL, NYK and Mitsui had either containerized or were about to embark on containerization. In particular, Maersk watched the developments in the Far East Freight Conference (FEFC) with concern. Kawasaki Kisen Kaisha and Maersk had since the latter half of the 1960 s collaborated on a Europe-Asia service. In the FEFC, they saw how other competitors moved swiftly towards containerization, and in the winter of 1970, it was announced that from 1972, at least 27 container ships would be deployed in the Europe-Asia services. In response to this paradigm shift, the year after, in 1971, Maersk and Kawasaki Kisen ordered one container ship each. Eventually, due to 'circumstances', Kawasaki Kisen Kaisha cancelled the agreement with Maersk, but since Maersk was committed to the trade, they continued to serve the Europe-Asia service with seven conventional ships, and chartered out the cellular container ship that they had ordered. One of many reasons for the slow venturing into containerization was due to the still profitable conventional liner services, and the fact that the liner division was committed to and strongly believed in conventional vessels, albeit with container capacity on deck. When the new Maersk Container Line division was created, the upper management could not just transfer people from Maersk Line into

8 This part is based on Jephson and Morgen 2014 and Jensen, L. 2014. Culture shock in Maersk Line - From Entrepreneurs and Kings to Modern Efficiency, Copenhagen: Vespucci Maritime Publishing. 
the new organization - in fact, operating a container service is very different from operating conventional break-bulk and pallet services. After this slow start, the Panama Line was containerized resulting in an order of nine "A-class" container vessels that were delivered between 1975 and 1976 . This shows that many companies struggled to face the growing challenge from containerization. Also, the rigidities that exist in any organization when facing a paradigm shift are obvious. Maersk, however, successfully adapted to the trend of containerization, which has proved successful up to the present ${ }^{9}$.

When it comes to refrigerated cargo, Maersk did some early ventures into owning reefer vessels, such as the M.S. Francine, acquired in 1936 and chartered out to J. Lauritzen, and owning conventional break-bulk carriers with reefer capacity from the mid-1930s. The move into containerized reefer cargo came with the A-class ships delivered in 1975-1976. They were equipped for ten refrigerated containers, and it was forecasted that the plugs would be used about 20 per cent of the time ${ }^{10}$. The reason for the conservative prognosis was probably due to two reasons. First, most of the refrigerated cargo was moved in dedicated reefers, which had made a solid inroad into refrigerated liner traffic in the 1960s. Second, the average size of the reefer vessels grew, which absorbed most of the growth in the market for maritime refrigerated trades. However, reefers had a significant drawback - the market price of refrigerated cargo (for example, bananas) would drop when large quantities of cargo arrived at the same port, as the market would be temporarily flooded. The conventional reefers dominated the market however, but the refrigerated container traffic by liner companies were starting to carry frozen meat in the early 1970 s and also non-traditional commodities, such as photographic film and enzymes. The arrival of the Maersk Newton ships in the 1980s significantly increased refrigerated cargo capacity.

Although refrigerated containers were bought at a cost of 3.2-3.7 times the price of standard dry equipment, Maersk saw the logic of continuing to explore the reefer market. In an internal report at Maersk, produced in 1986, the investigative team described the potential for penetrating the reefer market as follows:

- This is a technically complicated operation calling for reliability, competence and flexibility in the carrier

- Overall cost comparisons between self-contained and port-hole reefers clearly indicate that up to 300 units per ship, self-contained units were more

$9 \quad$ Jephson and Morgen 2014, ch. 2-3.

10 Jephson and Morgen 2014, p. 96, 111. 
cost-effective and flexible in terms of temperature, commodity stowage, refrigerating techniques and terminal handling

- Containerised solutions can be offered at freight rates competitive with traditional reefer tramp vessels and still be an attractive business

In mid-1986, Maersk Line's reefer capacity amounted to 160 plug connections per ship (in 28 ships) or an estimated 5 percent of the world reefer capacity. High cube reefer containers ( $40 * 8 \% 9.5$ feet) were developed and 1300 such containers were in operation in the Maersk fleet. The margins for refrigerated cargo was at Maersk considered to be good, ranging from 3900 USD to 6000 USD per container in the major trades ${ }^{11}$. It is stated that the "reefer market shares in the main trades were doing well, despite rates being under pressure in several areas of the world"12.

Certainly, during the history of Maersk, the main strategic aim was not to develop refrigerated trades, but Maersk did pay attention to this growing segment. For example, in 1985, the Panama Line was divided into two lines, where the first line would call at Japanese ports directly when arriving from the Us. This allowed Maersk to penetrate the major reefer trade from the us West Coast to Japan ${ }^{13}$. Another report was presented in 1986 about the trade to Australia. Five years earlier a study had shown that the Australia service might be viable, but at that time, there was no spare capacity on the Maersk ships. The follow-up report showed that positive results could be generated for Maersk Line. It is argued that these ventures made the size of the reefer market from this area visible.

In early 1992, a proposal was put forward to buy 150040 -foot reefer containers to supplement the existing fleet, and the order was signed. During the same year, two Maersk representatives visited a number of South American countries to evaluate if there was a market for the company's operations. They visited ports and also received a positive response from potential customers:

We visited a major fruit exporter who in no uncertain terms invited Maersk Line to participate in their seasonal movements ... Past good experience with shipments to Japan had convinced shippers that the reefer container (porthole concept disliked), was here to stay and would eventually capture the market. The service was inaugurated in $1993^{14}$.

\footnotetext{
$11 \quad$ Jephson and Morgen 2014, p. 111-113.

12 Jephson and Morgen 2014, p. 142.

13 Jephson and Morgen 2014, p. 130-131.

14 Jephson and Morgen 2014, p. 229.
} 
In the mid-1990s, the upper management of Maersk, in a report, noted that the reefer container fleet was growing at roughly double the rate of growth of the general containerised trade. Also, Asian importers controlled 70-80 percent of reefer movements from the us and Europe and strengthened sales efforts were needed to ensure the protection of Maersk Line's position. Moreover, "additional services to New Zealand and South Africa were expected to help Maersk Line grow in the reefer segment". Yet another move in the reefer market in 1997 was the introduction of the 'super-reefers', reefer containers catering mainly to Japanese fish importers providing temperatures as low as -6o degrees Celsius, suitable for transport of sea urchins, swordfish, food cultures, and pharmaceuticals ${ }^{15}$. In 1999, some ships that were on order carried 2500-3000 TEU, with 700 reefer plugs ${ }^{16}$.

Apart from the ships, in 1996, a reefer container plant was built by Maersk Container Industries (MCI) in Tinglev, Denmark, followed by an acquisition of a Chinese factory in 1999. One year before the acquisition of the factory in Qingdao, MCI had launched the Star Cool project to develop a reefer machine that was both reliable and that had a low energy consumption. Star Cool was achieved in 2005, and in 2012, 100 ooo units had been sold.

As is well known, since the end of the 1980s Maersk had been on an acquisition trail, acquiring companies such as the Danish East Asiatic Company, Safmarine, and P\&O NedLloyd. After having merged in 1999 with Sealand, the pioneer in containerization, Maersk-Sealand as the company was called, had become the largest reefer operator. Maersk-Sealand expected a growth in the reefer segment of 5.8 percent per year, where the main growth was in the frozen goods segment. Jephson and Morgan identify that the main strengths of Maersk-Sealand were in the fish, meat and deciduous fruit markets. Maersk-Sealand used high-technology reefer equipment, such as controlled atmosphere, high humidity or super-reefers. However, Maersk-Sealand's participation in the largest conventional reefer trade, namely bananas, was just 1.8 percent ${ }^{17}$.

The 2007-2008 financial crisis had a significant impact on Maersk Line's business, and in 2011, Maersk Line CEO Soren Skou described the situation in Maersk Line as a need to "get back to black". Regarding the reefer operations, his remarks are interesting:

\footnotetext{
15 Jephson and Morgen 2014, p. 249-250.

16 Jephson and Morgen 2014, p. 252.

17 Jephson and Morgen 2014, p. 271.
} 


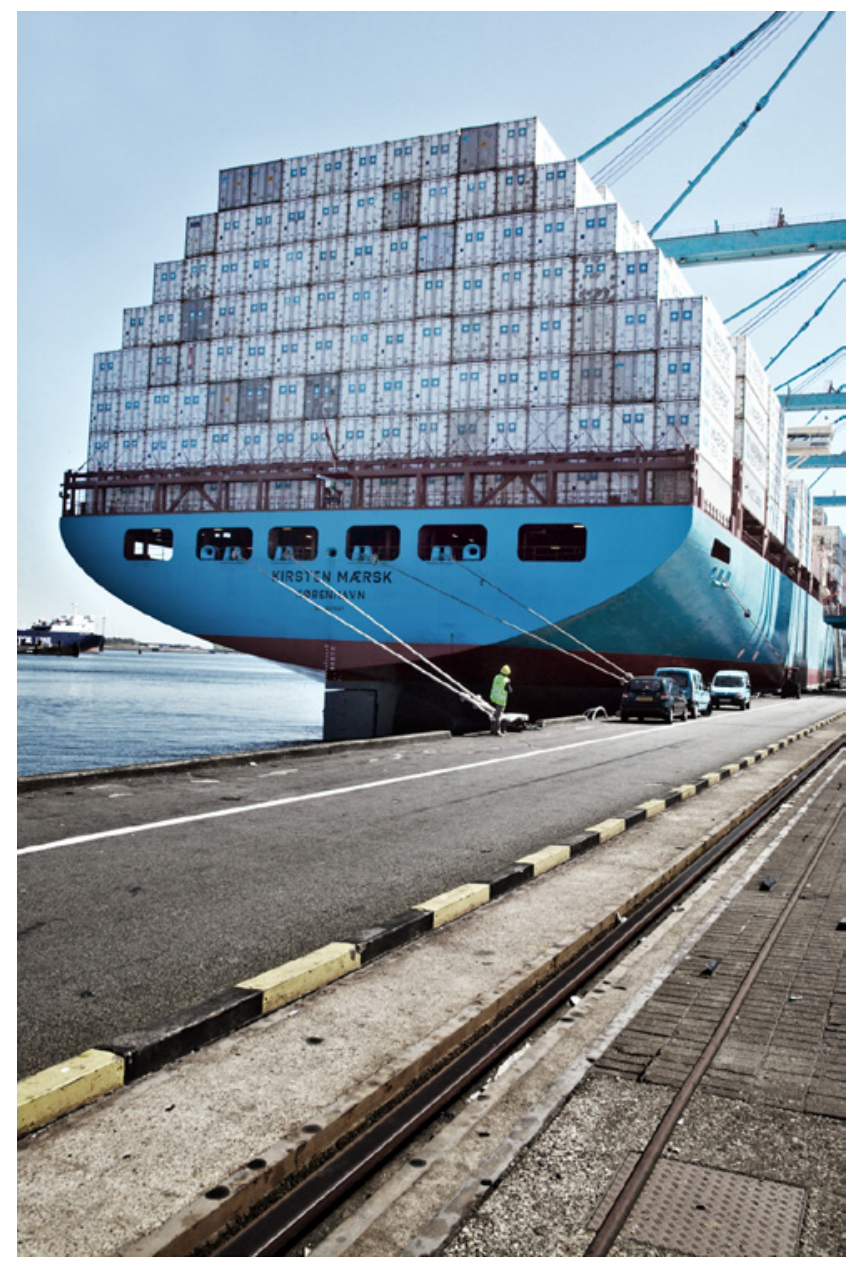

FIGURE 22

Modern container vessels have the ability to carry enormous quantities of reefer containers

PHOTO: MAERSK LINE

The reefer market is hugely important to us, and our mindset has been that every reefer is gold, that this is a great business. But when you look at the investment, where a reefer is four to five times the cost of a dry container, plus the plugs and power on the ships, and the fuel bill for running the reefers, then the return on the reefer business is disappointing and we have to get our returns up. I think that on the reefer side, we may have to invest a little bit of market share in getting prices up, not a lot, as there is not a huge amount of excess reefer capacity out there. We have a good chance of making that business attractive again. ${ }^{18}$ 
Jephson and Morgen state that Maersk had invested over 1.9 billion USD in a reefer fleet of 105 ooo FFE of reefers. Following up on Skou's analysis was a substantial price increase with effect from the first of January 2013 to bring reefer business Back to Black. In September 2012, Maersk announced a rate hike of 1500 USD per container ${ }^{19}$. A month later, the second largest reefer carrier, Mediterranean Shipping Company did the same ${ }^{20}$.

According to an interview with Shereen Zerkani, Global Head of Reefer Management of Maersk Line, in 2015, the low oil price has resulted in a comeback for some older, specialized reefers. However, she still believes that the future trend is toward containerization. Although at present the specialized reefers can thrive in the market, in the future their impact will be reduced.

In the past 10-12 years there's been a clear development toward containerization, as the bigger and more traditional container ships have taken over a big portion of reefer transports from the specialized reefer fleet. This development will continue ${ }^{21}$.

\section{Summary}

The independent reefer operators have always been developing alongside the liner companies. In this part we have discussed how the liner companies saw increased competition from the new, wild reefer operators, that could offer more direct lines with specialized vessels. This competition became increasingly difficult since the liner companies were forced to adapt to the trend of containerization in the 1960s and 1970s. At that time, the infrastructure, both container equipment and land-based facilities was not fully developed for the refrigerated trades. Slowly, the container lines started to take reefer cargo from the independent operators, from meat and fish to more sensitive cargo like fruit. The container lines, particularly Maersk, has seen the reefer cargo not only as the fastest growing segment but also as a suitable back-haul cargo. The market decline for the independent reefer operators since the mid-199os can therefore to a great extent be attributable to the come-back of liner companies.

19 Carriers put money on hybrid ship designs, Shanghai Shipping Exchange, 19 November 2012, <http://en.sse.net.cn/info/detailen.jsp?id=310233>.

20 "MSC applies 1500 dollar reefer rate hike globally Jan. 1". American Shipper 24 October 2012. <http://www.americanshipper.com/main/news/msc-applies-150o-reefer-rate-hikeglobally-jan-1-51647.aspx?taxonomy=Industries\#hide $>$.

21

"Maersk Line invests big-time in its reefer fleet". Shippingwatch 28 January 2016. <http:// shippingwatch.com/carriers/Container/article8393934.ece>. 
In an attempt to reposition themselves in the face of the comeback of the liner companies the operators started to position themselves as operating conventional reefers as opposed to containers, something that we will come back to in the chapters 12 and 13 . 


\section{Fruit Companies and Marketing Boards}

The major fruit companies have an intricate relationship to the independent reefer operators. As global fruit exporters, they operate shipping companies but are at the same time major customers to the independents. Indeed, what makes the reefer operators independent is that they are not exporters transporting their own cargo. What complicates the situation is that the fruit companies have sometimes operated third-party shipping, making them direct competitors to the independents. Given the importance and complexity of transporting their own perishable commodities to distant markets it follows that the major fruit companies have been pioneers and innovators of refrigerated maritime transport.

Marketing boards have been another major source of produce to be transported and therefore a major customer to the independent reefer operators. They have operated reefer tonnage but their importance as customers has declined over the years.

\section{$1 \quad$ Chiquita}

Chiquita's history is a complex one and can be traced back to several, at the time, important fruit companies. The company's relationship to the shipping industry has varied over the years. At times they have relied entirely on their own ships for the transportation of their fruit, while at other times they have outsourced parts and even their entire transport needs. The Great White Fleet - the shipping arm of Chiquita - peaked around 1970 when it merged with Salén's fleet, and again around 1990, when it grew to become a major commercial operator with a fleet of around 100 ships.

Chiquita's history can be said to start in $1871^{1}$, when the American railroad entrepreneur Henry Meiggs, assisted by his young nephew Minor Keith, agreed with the government of Costa Rica to build a railroad from San José to the port of Limón. Meiggs passed away in 1877 and Keith took over. He planted his first bananas in 1872 and before they had matured also bought some bananas in

1 This section is largely based on Adams, F.U. 1914. Conquest of the Tropics: The story of the Creative Enterprises conducted by the United Fruit Company, New York: Doubleday. Page \& Company, ch. 3-4. 
Colon which were profitably sold in New Orleans in that same year. The Costa Rican government defaulted on their payments in 1882, which led to Keith being granted 3200 sq.km of land as well as a 99-year lease on the operation of the railroad. The railroad proved difficult to build and was finally completed in 189o, but rather than making money on passengers, Keith realized that it was more lucrative to transport bananas to Limón and thereafter ship them to New Orleans. He established a position where his companies including the Tropical Trading and Transport Company dominated the Central American and Columbian banana trades. However, a broker's bankruptcy put Keith in a difficult financial position, resulting in the merger of his company with Boston Fruit and the establishment of United Fruit. The catalyst that led to the establishment of Boston Fruit is recorded as Captain Lorenzo Baker's voyage in 1870. He was looking for backhaul cargo in Jamaica and bought 160 bunches of bananas in Jamaica, and after a quick voyage, sold them profitably in Boston. Andrew Preston, a Boston fruit merchant, realized that the business had potential and started to trade in bananas and in 1885 Boston Fruit was established. Ten years later, the company owned 35 banana plantations and a fleet of steamships bringing cargo to Boston, Philadelphia and Baltimore. With the help of lawyer Bradley Palmer, United Fruit was created in 1899.

The new company combined the various companies that were controlled by Minor Keith and the Boston Fruit Company. Andrew Preston became President, Minor Keith was Vice-President and Lorenzo Baker was one of the board members. United Fruit was profitable in its initial years ${ }^{2}$ and entered into a phase of rapid expansion buying competitors and developing the business. Particularly important from the reefer perspective was the acquisition of $50 \%$ of Elders \& Fyffes in 1903 which enabled United Fruit access to the underdeveloped European market, which Elders \& Fyffes were already developing. And it was this transatlantic business, in particular, that spurred the development of refrigerated banana transport.

Ships have always been an important part of any banana company's operations. In the early period from 1870 s to the end of the 1920s, the output of each plantation was determined by the size and frequency of available shipping ${ }^{3}$. The ships of United Fruit are mythical in the reefer industry and there are indications that already in 1899, the company painted their ships white to reflect the tropical sun in an attempt to reduce heat. United Fruit operated over 60

2 United Fruit Annual Reports 1900, 1901, 1902, 1903, 1904.

3 Read, R. 1986. The Banana Industry: Oligopoly and Barriers to Entry, in Casson, M. (ed.). Multinationals and World Trade, London: Allen \& Unwin, pp. 317-342. 
steamers in 1901, ten of them owned and the remainder on time-charter ${ }^{4}$. In 1903, United Fruit converted the steamer Venus to a refrigerated ship. Experimentation with appropriate temperatures on the Venus, led to the development of three coal-fired steamers that were purpose-built for the fruit trade in 1904. More new-buildings followed and the trend was for the ships to become larger and to be fitted out with refrigeration. They also carried passengers. A large part of the fleet, mainly ventilated vessels, continued to be chartered, and significantly from Norwegian companies 5 . Scandinavian companies were to later become major actors in the field of fruit transportation. The Great White Fleet is usually associated with the United States naval fleet that circumnavigated the globe between 1907 to 1909, but it also became the name of United Fruit's shipping arm. By 1910 the company owned seventeen ships and also purchased the remainder of Elders \& Fyffes including its fleet ${ }^{6}$.

Diseases were to become a major problem for all banana producers. United Fruit detected the Panama disease on two of its farms in 1916 but the disease had previously been detected in other parts of Central America ${ }^{7}$. Another disease, Sigatoka, which had been recorded in Java and Fiji at around the same time and later ravaged banana farms in Australia in 1924. The disease reached banana plantations in Central America in the mid-193os and caused major damage to United Fruit's plantations ${ }^{8}$. Sigatoka could be controlled by spraying while Panama disease could be managed to some extent by flood-fallowing. These diseases added to production costs and also led to a search for diseaseresistant varieties.

United Fruit's share of the world trade in bananas in the early $20^{\text {th }}$ century has been estimated as high as $77 \%{ }^{9}$. Monopoly allegations caused United to dispose of some of its holdings between 1908 and 1912 and this made the market more competitive ${ }^{10}$. By 1930, in the face of increased competition from Standard Fruit and Cuyamel, United Fruit had absorbed more than 20 rivalling firms and its market share was around $60 \%{ }^{11}$. United Fruit owned ninety ships in 1931 and also leased twenty-five ${ }^{12}$. In 1939 it had an estimated market

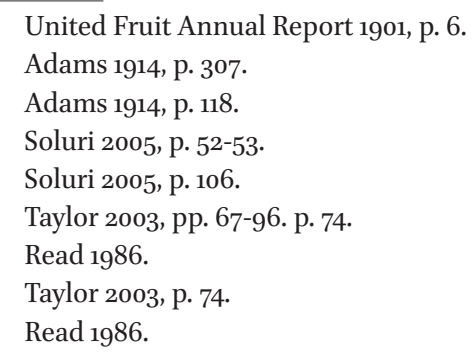


share of $65 \%$ of the banana trade and had 54 ships, plus another 21 in the Elders \& Fyffes fleet ${ }^{13}$. Directly after the Second World War, they added yet another 18 ships to its fleet ${ }^{14}$ and furthered its relationship with Salén in Sweden.

United Fruit had a long history of political involvement in Latin America and had also successfully lobbied the us government to intercede on its behalf on several occasions. It is the clout of the banana companies (and United Fruit was the biggest) in respect to Central American countries that gave rise to the idea of the "banana republic". United Fruit's controversial involvement in the region gave it a competitive advantage on world markets since they managed to minimise production and land costs by supporting regimes that gave the company what it wanted with doubtful concern for the consequences to workers and indigenous peoples. In the 1950s United Fruit successfully lobbied for the toppling of the elected government in Guatemala ${ }^{15}$. However, it can be mischievously said that the us had been opposing monopolies for longer than it had been stamping out communism. In the same year as the us-backed insurrection, in 1954, the Eisenhower administration brought an anti-trust suit against the company and United Fruit were going to be forced to divest some of its interests. What was demanded was that the company ceased its direct sales of bananas to retailers in the us market, that they acquired no more banana companies, and that they submitted a plan to spin off a banana company by 1966. In 1967, United Fruit announced that the new company would consist of the Armuelles Division on the Pacific Coast of Panama ${ }^{16}$ but it was ultimately the Guatemalan banana business that was disposed of to Del Monte ${ }^{17}$. So ironically, United Fruit's lobbying to remove a government resulted also in its own departure from that country.

Bananas were loaded on the ships in bunches, but in the early 196os, following the lead taken by Standard Fruit, United Fruit started to experiment with the transport of bananas in cardboard boxes, to protect them from bruising. United Fruit had been experimenting for decades with modifying the atmos-

13 Tolerton 2008, p. 186.

14 Tolerton 2008, p. 186.

15 Immerman, R.H. 1982. The CIA in Guatemala: The Foreign Policy of Intervention, Austin: University of Texas Press.

16 McKern, B. and Dunning, J.H. 1993. Transnational Corporations and the Exploitation of Natural Resources, Abingdon: Taylor \& Francis. pp. 205-206. Neumann, P. and Somer, J.A. 2000. Reefership: The Art and Science of Supplying Fresh Produce to the world, Dole Fresh Fruit International, p. 6o. 
phere to delay ripening and this was now also applied to the individual box and a patent was awarded at the end of the decade.

Eli Black, who started his career at the now defunct Lehman Brothers, became the chairman of American Seal-Kap Company, which traditionally made seal caps for milk bottles. Black renamed this company AMK and used it as a vehicle for acquisitions. He starting purchasing shares of United Fruit and by 1969 had taken control, fired part of the management and raised the stock price from 16 to 81 USD. After merging the company with John Morell meatpacking company, United Fruit changed its name to United Brands. On the shipping side, it was decided to merge the fleets of Salén and United Brands, leading to a massive fleet of 130 ships. United Fruit continued to be at the forefront of refrigerated transport and as early as 1972 bought its first two refrigerated container vessels for a service between Honduras and Gulfport. These Spanish-built ships were expensive to run after the oil crises and were replaced in 1983 by the more efficient Puritan class.

But United Brands was in severe trouble and the hurricane Fifi added to the gloomy situation, destroying many of the company's banana plantations in Honduras. In 1975, the Securities and Exchange Commission discovered that Black had bribed the Honduran president to reduce banana export taxes leading to Black's suicide. Following these events, the American Financial Group, run by Carl Lindner Jr, bought into United Fruit, and in 1984 Lindner changed the company name to emphasise its key brand: Chiquita Brands.

Driven by the Lindner family and Dale Ploughman, Chiquita vigorously expanded its fleet using the company's historical shipping brand: The Great White Fleet. Moreover, their reefers were used for third-party shipping to a greater extent than before. They built several reefers at Danyard and Kvaerner Kleven and three pure container ships that were built in Japan. In 1993, The Great White Fleet controlled 65 ships, of which they owned $20^{18}$ and the total later reached around 10o. This development was driven by the introduction of the licensing system for the import of bananas to the European Union. Many believed that the licenses would be distributed in proportion to the volume of business that banana companies had in Europe, which led Chiquita to dramatically increase their volumes to position themselves. However, it did not turn out that way and Chiquita was instead faced with increased restrictions that caused its market share within the EU to plummet. This placed Chiquita in a very difficult situation ${ }^{19}$. It also had repercussions for many other parties, particularly for the countries that were heavily reliant on Chiquita. It also led

18 "New Chiquita reefer grounds, then faces unwanted lay-up". TradeWinds 9 July 1993, p. 6.

19 "Chiquita loses EC banana case". TradeWinds 9 July 1993, p. 27. 


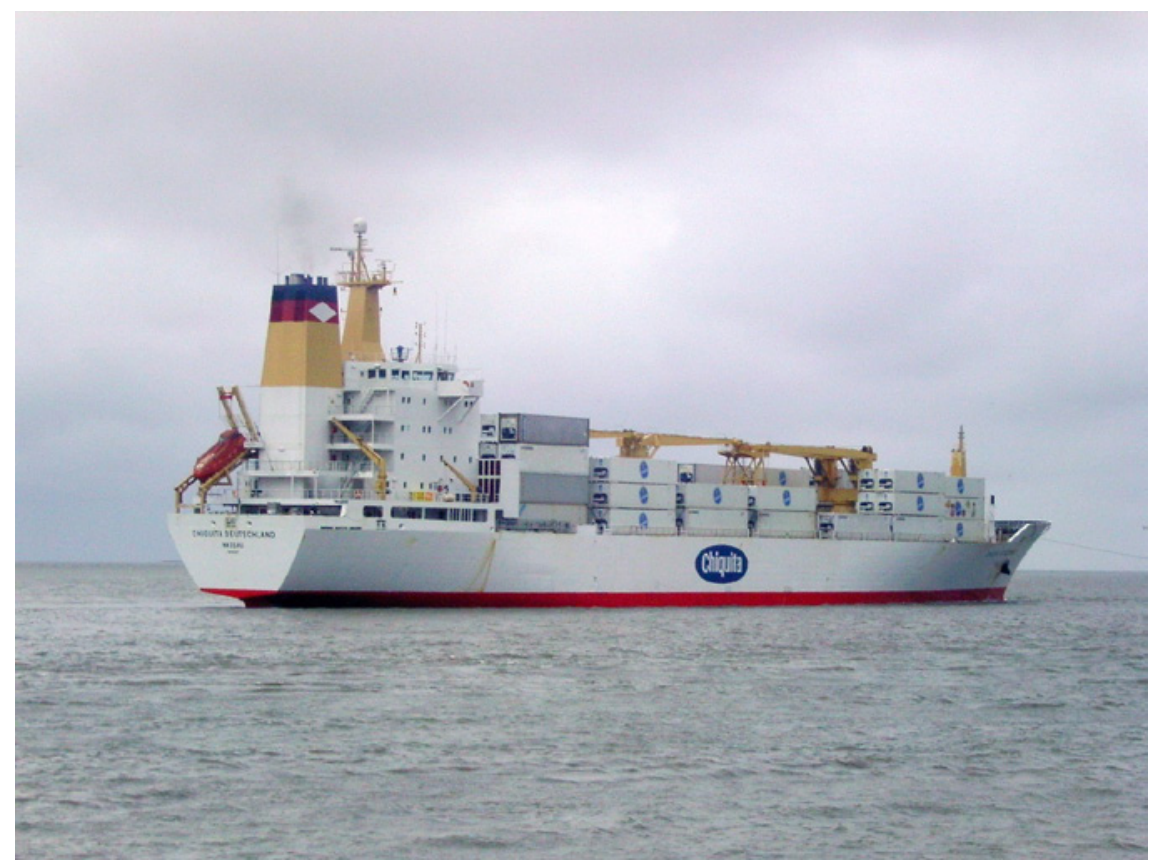

FIGURE 22 The Chiquita Deutschland was the first of a series of six "Country Class" reefers built in 1991 and 1992 for Chiquita at Danyard, a shipyard owned by J. Lauritzen. They were for many years a mainstay of Chiquita's banana trade to Europe Рното: TVABUTZKU1234.

to the cancellation of various contracts, for example, the time charters with Holy House shipping in 1993 .

Chiquita tried to improve its financial situation by selling its meat business in 1995. Further appeals began to offer the prospect of the EU's banana licensing system becoming more advantageous for Chiquita, but the damage had been done. In 2001 Chiquita filed for Chapter 11 bankruptcy, which effectively ended Lindner's ownership of Chiquita in 2002. In 2004, Chiquita bought Fresh Express, whose primary business was packaged salads but this turned out to be a disappointment. Yet again Chiquita divested assets to improve its finances, this time ships. In 2007, Chiquita signed a shipping agreement with its longterm partner NYKCool, with roots in Salén, which involved the sale and leaseback of 12 ships. In 2015, Chiquita was completely acquired by Cutrale-Safra group. 
The company that we now know as Dole has, just like Chiquita, different origins. One strand, particularly important for bananas and shipping, started with the Vaccaro brothers and later became Standard Fruit. Italian émigrés were active in the American fruit trade and pioneers in this regard were Salvatore and Guiseppe Oteri who were based in New Orleans. As an example, in 1878 they purchased a 454-ton steamer and carried 1000 stems of bananas, 15000 plantains, 7000 pineapples and four barrels of limes to New Orleans from Honduras $^{20}$. Many Italians had immigrated either to New York or New Orleans, many were farmers who had lost their land in Italy, and some turned to the fruit trade in the U.S. One of those Italian families was the Vaccaros. After farming failures, due to the Mississippi River flooding and a winter freeze in 1899, the Vaccaros and D'Antoni decided to follow in the footsteps of the Oteris. The Vaccaros bought fruit in Honduras and transported it by sail in 1899, and the year after they acquired a steamship. By comparison, United Fruit controlled 36 vessels at the time, so the Vaccaros were certainly underdogs ${ }^{21}$. The Vaccaro Brothers Fruit \& Steamship Company offered biweekly services in the Caribbean.

The Vaccaros sold half of their business to United Fruit in 1905 to finance the construction of a railroad from the plantations to the coast, but only a few years later, in 1908, the Vaccaros bought back the share. The fleet was renewed in 1911, when the ventilated fruit carriers Ceiba and Yoro were built. Although the levels of exports were high in the 1920s, the Vaccaro business was not healthy. In 1926, they incorporated as Standard Fruit \& Steamship Corporation, and went public. Standard grew before the Depression, becoming a diversified company owning railroads, oil, and real estate apart from the fruit business. During the Depression, Standard continued to expand its fleet, for example converting four old us destroyers to banana boats. The rapid fleet expansion along with the difficult economic situation caused problems and the company was reorganised in 1935. Similarly to many of the companies we cover in this book, Standard's ships were used in the Second World War.

In the 1950s, Standard was the second largest banana importer in the Us, after United. Similarly to United, Standard was struggling with the cost of treating Sigatoka disease and particularly Panama disease that attacked and destroyed banana plants and then remained in the ground. While United Fruit continued to manage this problem by flood-fallowing, leaving the infected land immersed during 3-6 months, Standard was running out of land to do

$20 \quad$ Neumann and Somer 2000, p. 45. 
so. The method was also capital-intensive and continued labour unrest made Standard's situation worse. Standard had, however, been experimenting with disease-resistant varieties for some years. In 1956 Standard decided to switch its production to the Giant Cavendish despite opposition from fruit distributors who preferred the existing Gros Michel. The Cavendish was sensitive to bruising and also required additional measures to ripen properly. Standard had also been trialling boxing bananas as early as the 1930 and this measure was employed to overcome the bruising issue. Boxing the bananas at the plantation reduced the amount of handling that the bananas were exposed to and this innovation was later picked up by United ${ }^{22}$. But the costs associated with the switch to Cavendish and boxing were factors behind the company's decision to sell its entire of fleet of 29 vessels in 1962. Standard's tonnage requirements were met by time-chartering vessels from Saléns and other independent reefer operators. In 1964, $56 \%$ of the company was acquired by Castle \& Cooke and the rest of it in 1968.

Castle \& Cooke had a history going back to 1851 in Hawaii, with the missionaries Castle and Cooke, who turned into successful merchants by running general stores and sugar plantations ${ }^{23}$. They had come to dominate the Hawaiian pineapple business during the Depression and established business in California in 1934. By the early 1960 os it was a diversified company with sugar, real estate, and the Matson shipping line. At the time of the merger, United Fruit had $70 \%$ of the banana market, while Standard had $15 \%$.

The third part of Dole was the business of James Dole. Moving to Hawaii in 1899, he was inspired by Castle \& Cooke, bought some land and started to plant fruit and particularly - the pineapple. Rather than selling on the local market, he was convinced that the fruit had to be exported, but he saw some difficulties in exporting it fresh. He therefore raised the capital to build a canning factory and started to can the fruit. When the Hawaiian pineapple tariff was abandoned in 1901, James started to export canned pineapples to the U.S. His Hawaiian Pineapple Company (Hapco) filled 43000 cans in 1903 and three years later it was close to a million. By 1922, Hapco was a top pineapple producer, and Dole traded a third of the shares in the firm for cash and a long-term lease of 12000 acres of Waialua's land. With the cash, he bought the 9oooo-acre island of Lanai and turned it into a massive pineapple plantation. In 1928, it accounted for a third of the pineapple market share, and two thirds of the land under pineapple cultivation. The Great Depression hit Hapco hard, holding a large inventory of canned fruit when sales plummeted, and owing large amounts of

22 Neumann and Somer 2000, p. 58. Soluri 2005, p. 177-18o.

23 Neumann and Somer 2000. 
money to banks and other creditors in order to enlarge its production capacity. Due to this trouble Hapco was essentially merged into Castle \& Cooke in the mid-1930s. Jim Dole became the figurehead chairman, with little influence, and soon retired. Standard's bananas had previously been marketed under the Cabana brand and the acquisition of Dole meant that the company could leverage this better-known brand for its bananas. Dole was of course a pineapple brand. In 1972 the Dole brand was advertised in the us with the slogan "Dole has gone bananas", a campaign that was described as "one of the most aggressive advertising and promotion campaigns ever seen in the banana business" 24 .

Dole shipped its first bananas to Europe in $1965^{25}$ and formed Eurobana in 1972, a partnership with the German fruit company Astheimer \& Sohn in Hamburg, which it later took over. A few years later they expanded their business in Japan with collaborations with two Japanese trading companies.

Dole decided to return to ship-owning in 1976. The shipping component of the business had become more significant because of the rise in oil prices and Dole therefore considered continued reliance on third-part tonnage to expose them to too high a level of risk. Instead they adopted the policy that a third of their ships should be owned, a third should be short-term chartered and a third on long-term charters ${ }^{26}$. Castle \& Cooke created a fully owned subsidiary to handle the transport needs called Intercontinental Transportation Services (ITS). In late 1976, ITS acquired two Clipper type ships, Golar Frost and Golar Freeze from Irgens Larsen and followed this up by purchasing two ships, Mandarincore and Sabracore, from the defunct Maritime Fruit Carriers. In 1977, ITS purchased four Frubel ships from Belgian Fruit Lines which led to a collaboration with Dammers and van der Heide, who in 1979 delivered six Honolulutype ships to ITs. In 1978, Castle \& Cooke acquired the assets of Willy Bruns of Hamburg which included seven reefers, Bruns operations in Europe and Ecuador, the banana producer Ubesa in Ecuador, a box manufacturing plant and production contracts with independent growers ${ }^{27}$. In 1983 , ITs moved to Boca Raton, and the fleet operations were managed by Benjamin Paz. Paz started a newbuilding project that led to the delivery of four vessels Tropical Mist, Tropical Morn, Tropical Sky, and Tropical Star. ITs also took over the ships' technical management but relied on Irgens Larsen for crewing. A further two Clipper vessels were acquired in 1987 .

24 The New York Times January 17, 1972, p. 48.

25 Neumann and Somer 2000, p. 60.

26 Neumann and Somer 2000, p. 101.

$27 \quad$ Neumann and Somer 2000, p. 199. 


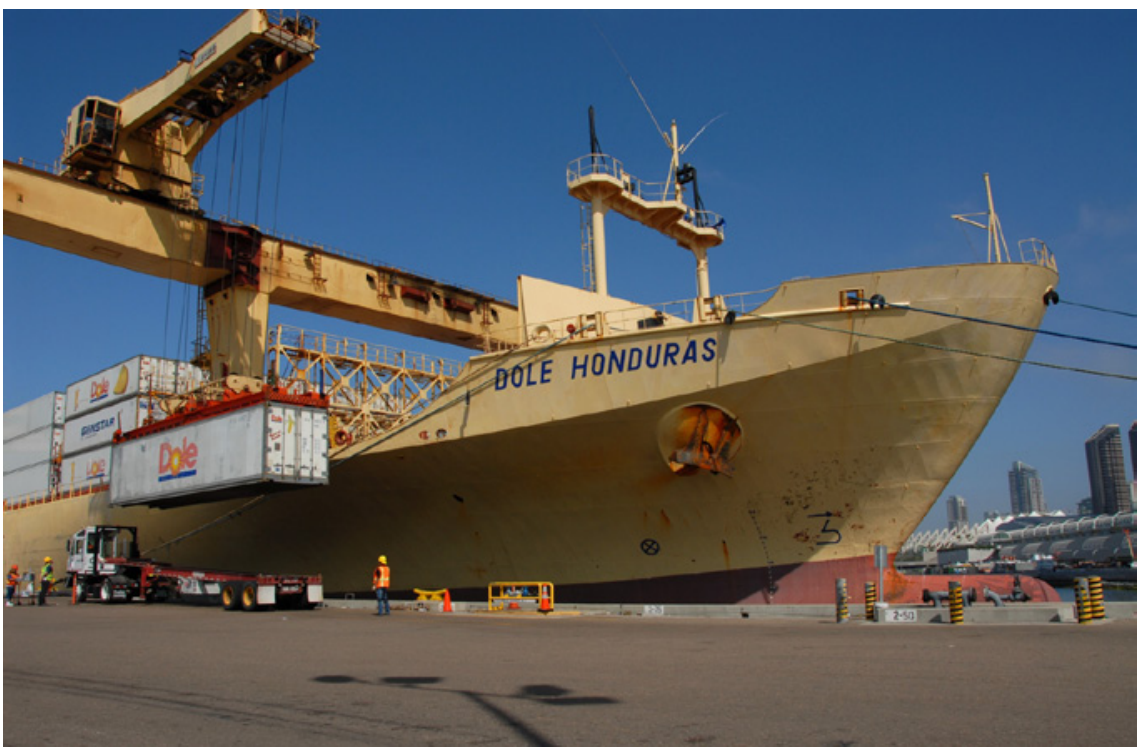

FIGURE 23 Dole Honduras in San Diego, 2008. Dole increasingly containerised its banana transport to the USA from the 1980 s and built modern reefer container ships PHOTO: PORT OF SAN DIEGO (DALE FROST)

The company was relocated to Costa Rica in 1991 and reorganized as Dole Fresh Fruit International, DFFI. In 1992, DFFI went into collaboration with Caesar Reefers, who had built six reefers at the Gdansk shipyard. Later, these ships were bought by Oetker, placed in the Star Reefers pool and timechartered to Dole. Dole were happy with these ships and decided to ordered four similar ones from the same shipyard. Dole also started to time-charter vessels from NYK.

While United Fruit had started a container service from Honduras to Gulfport in 1972, Dole started its Central American container service in 1981. The Jade Bounty and the Sapphire Bounty serviced the trade. Dole add the reefer container vessel Concord in 1982, and three more ships in 1983. In 1987, Cartagena and Santa Maria entered into Dole transport system, servicing the trade between Colombia and Jacksonville ${ }^{28}$. In 1989, DF FI took delivery of Dole California and Dole Ecuador with a capacity of $450 \mathrm{FEU}$, followed by the Dole Honduras and Dole Costa Rica. Their container capacity was later expanded to 500 FEU. Dole's reefer container shipping was further enhanced in 1999 when two larger ships were built, Dole Chile and Dole Colombia, each with a capacity of 1023 FEU. These sophisticated vessels carry around a million banana boxes per

$28 \quad$ Neumann and Somer 2000, p. 104. 


\section{Antares J}

Dole Africa

Dole America

Dole Asia

Dole California

Dole Chile

Dole Colombia

Dole Costa Rica

Dole Ecuador

Dole Europa

Dole Honduras

Eurus Lima

Eurus Lisbon

Eurus London

Eurus Paris

Tropical Mist

Tropical Morn

Tropical Sky

Tropical Star

a See <http://www.doleoceancargo.com/vessels.html $>$.

voyage and have their own gantry cranes. Dole then controlled a fleet of about 30 ships but this number was later reduced, the newer ships had ample capacity. Modernisation continued when three $770 \mathrm{FEU}$ ships were ordered from the South Korean Ulsan yard in $2013^{29}$.

Meanwhile, in August 1991, Castle \& Cooke diversified into real estate, and a separation was made where Castle \& Cooke became the real estate company, while Dole was responsible for fruits ${ }^{30}$. In 1993 Dole made an effort to increase its access to the European banana market by acquiring interests in companies that sourced bananas from the African, Caribbean, Pacific areas that were fa-

29 "Dole orders in Korea". TradeWinds 10 July 2013.

$30 \quad$ Neumann and Somer 2000, p. 71 
voured by the EU regulations. A bid for Fyffes was rejected ${ }^{31}$ but Dole subsequently gained a $40 \%$ share of Compagnie Fruitière and kept this until 2014. This company uses Africa Express Line for its transport from West Africa to Europe. Africa Express Line chartered pallet-friendly reefers and in 2016 were operating eight such vessels from Star Reefers and Fresh Carriers. A recent addition, however, was a new reefer-container vessel from Seatrade, the Seatrade Orange.

Dole has continued on as a ship-owner but it also charters in vessels. Dole's commercial shipping operation is managed by the subsidiary Dole Ocean Cargo and the ships are managed by Dole Reefership Marine Services. Dole Ocean Cargo operated in 2016 lines linking Ecuador to San Diego, Central America to Gulfport, Central America to us East Coast, and Central America to Antwerp. The latter line was serviced by pallet-friendly reefers while the services to the us employed reefer-container vessels. Dole reefers were also employed in the Far East.

Dole became the world's largest supplier of bananas in the early $21^{\text {st }}$ century and the leading shipping operator amongst the fruit companies. Their modern reefer-container vessels are regarded as state-of-the-art.

\subsection{Fyffes \& Geest}

The origins of Fyffes can be traced to Fyffes Hudson and the shipping company Elder Dempster that both started shipping bananas from the Canary Islands to Britain in the late $19^{\text {th }}$ century. Elder Dempster bought Fyffes Hudson in 1901 and inaugurated the refrigerated transatlantic banana trade when the Port Morant of the Imperial Direct West India Mail Service arrived in Bristol in 1901. The British Government subsidised the operation since it was also a mail service. The acquisition of Fyffes Hudson's fruit distribution business, combined with the Port Morant's success led Elder Dempster to establish Elders \& Fyffes as its purchasing company and established the Fyffes Line to specialise in banana shipping. The first ever purpose-built banana reefers were ordered for Fyffes in 1903 but the company had to turn to United Fruit for banana supply in the same year, partly due to a hurricane that destroyed the Jamaican crop. Subsequent supply agreements included United Fruit's acquisition of half of the company and in 1910, the entire operation. Elders and Fyffes continued as a separate division and was focused on supplying bananas from the West Indies to Europe although a banana plantation in the Canaries was also developed. ${ }^{32}$

$31 \quad$ "Dole's bid for Fyffes falls flat". TradeWinds 23 April 1993, p. 5.

32 This section is largely based on Read 1986, and McCutcheon, C. 2010. Elders \& Fyffes: A photographic history, Gloucestershire: Amberley Publishing. 
The company pioneered banana branding by introducing the Fyffes "Blue Label" on its bananas in 1929 and it was the market leader in Europe. Fyffes' fleet was very interlinked with United Fruits. By the start of wwI Fyffes fleet had grown to 18 ships but ten of these were lost in the war. Rapid expansion later resulted in a fleet of 36 vessels in 1932. The Depression and other problems scaled back the fleet to 21 by 1938 . Fyffes built a few ships in 1949 and 1956 but then withdrew from ship-owning in the early 1970s. In 1986, Fyffes was taken over by Fruit Importers of Ireland. In 1996, Fyffes and Wibdeco (Windward Islands Banana Development and Exporting Company) acquired Geest's banana business.

Geest had in itself been an important player in the banana market. This originated with a Dutch flower-growing business that was diversified after the brothers Jon and Leonard van Geest moved to the UK in the 1930s. Banana imports from the Windward Islands started in $195^{2}$ and the company's first banana reefers, Geestland and Geeststar, entered service in 196o. By the end of the decade Geest controlled around half of the UK banana market and the fleet was steadily growing. More ships followed including a vessel in the early $1970 \mathrm{~s}$ that could carry 340 containers $^{33}$. The Geest St Lucia and Geest Dominica from Danyard in 1993 were the last ships delivered to Geest as an independent company. Geest Line continued to charter vessels that were used to operate services that ship bananas from the Caribbean to France and the UK and miscellaneous cargo on the return voyage.

Fyffes, now as an independent company, expanded its presence in the us by partnering with Columbian UniBan in 2005. The company has particularly focused on Fairtrade bananas and was the largest supplier of these to Europe ${ }^{34}$. A proposal to purchase Chiquita in 2014 failed to eventuate ${ }^{35}$. In 2014, the company operated eight specialized reefers.

\section{3} Del Monte

California Fruit Canners Association (CFCA) was formed in 1898, and one of its brands was Del Monte, known for its canned peaches. In 1916, CFCA merged with other companies and incorporated itself as California Packing Corporation and began marketing many of its products under the Del Monte brand. In

\footnotetext{
33 Tolerton 2008, p. 169.

34 Fyffes Annual Report 2015, p. 23.

35 Fyffes Annual Report 2015, p. 14.
} 
the 1910 and 1920s, it operated many canneries, and acquired pineapple farms and a cannery in Hawaii. An international expansion followed and in 1967 rebadged itself as Del Monte, its best-known brand.

In 1967, United Fruit bought a $6 \%$ share in Del Monte as a first step in taking over the company. Del Monte were able to fend this off however. Since United Fruit were barred from acquiring another banana company, due to anti-trust legislation, they entered the banana business. They bought the Tampa based West Indies Fruit Company which had purchase contracts with banana producers in Ecuador and Costa Rica. Del Monte were also looking for new opportunities. The company began operations in the Philippines, expanded its banana purchases, set up a plantation in Costa Rica, and bought six reefers. Del Monte was able to further expand when United Fruit were forced to divest some of its interests, once again due to anti-trust issues. Del Monte negotiated with United Fruit about the purchase of the Armuelles Division, but the deal was turned down by the Panamanian government. Instead Del Monte bought United Brands division in Guatemala - the Bananera Division in 1972. This led Del Monte to become a major competitor to United Brands and Standard Fruit.

The ownership of Del Monte changed hands a number of times in the late twentieth century. In 1979, Del Monte was bought by R.J. Reynolds who sold the company to Polly Peck International in 1989. Del Monte had grown to be the largest supplier of fresh pineapples in the world and also the third largest in bananas ${ }^{36}$. In 1996, Del Monte was acquired by the Jordanian IAT Group, controlled by the Abu Ghazaleh family and the company continued to be the market leader in pineapples, with $40 \%$ of the market, and remained the third largest in bananas ${ }^{37}$.

Network Shipping was incorporated in 1990 as the company's shipping subsidiary managing and operating a fleet of $3^{2}$ vessels, partly owned and partly chartered-in ${ }^{38}$. In 1993 as Global Reefer Carriers was established. Del Monte built new reefers and also acquired older vessels and by the end of the 1990s their fleet consisted of 43 ships $^{39}$. In 1997, they completed its acquisition of Horn Line, which had been a long-time transport partner carrying fruit to $\mathrm{Eu}$ rope $^{40}$.

36 "British Conglomerate to Buy Part of Del Monte from RJR". Los Angeles Times 8 September 1989 .

37 Neumann and Somer 2000, p. 106., Fresh Del Monte Produce 1997 Annual Report p. 7.

38 "Network Shipping starts Us-Costa Rica service". Journal of Commerce Mar 20, 1991. <http://www.joc.com/maritime-news/network-shipping-starts-us-costa-rica-service 19910320.html>.

39 Fresh Del Monte Produce 1999 Annual Report p. 4.

$40 \quad$ Fresh Del Monte Produce 1997 Annual Report p. 3. 
By 2006, the fleet had been reduced and the company owned 20 reefers and chartered in another five units. In 2009 and 2010, Del Monte started a ten-year charter of four vessels from Star Reefers, sticking to non-containerized specialized reefer vessels. As of 2015, they owned 13 vessels and were chartering in a further six. They also spot chartered vessels according to seasonal requirements. Del Monte also owned and leased refrigerated containers, and continued its strategy of being a vertically integrated food company ${ }^{41}$. They maintained their leading position within the pineapple segment and its number three place in bananas ${ }^{42}$.

National marketing boards are official institutions with a state-mandated monopoly to buy or sell a particular commodity. Early examples include the New Zealand Meat Producers Board formed in 1922 and the New Zealand Dairy Board in 1923. This type of board was established to improve returns to farmers and focused on pooling and selling national produce. The extent to which these boards are controlled by producers and their degree of autonomy from the national government has varied somewhat in different countries and at different times. Another kind of marketing board, frequently associated with developing countries and centrally planned economies, is set up as a buying monopoly.

One example of a marketing board on the buying side is the Comite Interprofessionel Bananier (СІв) created in 1932 to organise the French market for bananas. The board consisted of representatives from Government, agents, ripeners-wholesalers, shipping companies as well as producers from the preferred regions. French banana marketing was based on its support of domestic production in Martinique and Guadeloupe as well as that of African countries in the franc-zone, chiefly Côte d'Ivoire and Cameroon. The сів was reorganised several times but the strategy was to support these producing regions and to achieve stable pricing by matching supply with demand. Bananas were sourced from other regions as required to make up for any shortfalls from the preferred producers. Shipping the bananas from the Caribbean was in the 1970 carried out by reefers operated by the state-owned Compagnie Générale

$41 \quad$ Fresh Del Monte Produce 2015 Annual Report p 8.

42 Fresh Del Monte Produce 2015 Annual Report p 2. 
Transatlantique and its successor Compagnie Générale Maritime which containerized banana-transport in the years around 1980. ${ }^{43}$

The Soviet Union's banana imports were handled, after 1966, by Soyuzplodoimport which was a state import and export agency, best known for vodka exports. The UssR's banana imports were limited by its reluctance to spend its hard currency reserves on non-essential imports - reciprocal trading arrangements were preferred. The UsSR prioritised the purchase of bananas from national organizations thereby avoiding us based companies like United Fruit. Reefers from the national shipping line Sovfracht shipped bananas from Columbia and Ecuador, as well as small quantities from various lesser-producing countries such as Vietnam, to mainly Riga, Tallinn and Odessa. ${ }^{44}$

The national marketing board and the specialised reefer were a perfect match. The board was a planned operation with high cargo volumes of a single commodity. The marketing board commanded a monopoly and negotiated from a position of strength. Zespri, the New Zealand Kiwifruit Marketing Board, is a successful and surviving example of a board on the supply side. Although regarded as a tough customer that expected low rates it had the advantage, from the reefer operator's standpoint, of being a "single desk" representing large volumes of a single commodity.

These operations, the large seasonal trades of for example grapes from South Africa is a good example, were well suited to the large specialised reefers operated by Saléns/Cool Carriers, Lauritzen and others (including Holy House, in the 1990s with the aging but still capable Snow vessels). The independent reefer operators were also ideal from the perspective of the marketing boards since they could maintain a greater degree of control over the cargo. Maintaining control over an exported commodity was a reason why the boards existed in the first place. A chartered specialised reefer is under the charterer's control and the cargo can be sold and resold whilst en route. The port destination is easier to change and this stands in contrast to shipping the goods with a liner operation.

Some marketing boards were slow to switch to containerization and continued to be major charterers of non-containerized reefer tonnage. One explanation given by our respondents was that a marketing board may be more resistant to change than a more dynamic privately-owned operation. Another explanation that has been offered is that they may prioritise dependability and

43 Food and Agriculture Organization of the United Nations. 1986. The World Banana Economy, 1970-1984: Structure, Performance, and Prospects, Rome: FAO. p. 44-45.

44 Food and Agriculture Organization of the United Nations. 1986. The World Banana Economy, 1970-1984: Structure, Performance, and Prospects, Rome: FAO. p. 54. 
refrigeration quality and keep a longer-term perspective than a listed company that can be castigated for a poor quarterly result.

Most of the marketing boards were abolished or given a reduced mandate during the 1980 s and 9os. The Citrus Marketing Board of Israel, for example, lost its role as exclusive exporter in $1991^{45}$. This was linked to the general move towards deregulation and privatisation. Larger producers in particular lobbied for their abolition. The boards, it was argued, were an ineffective bureaucratic obstacle, an unnecessary link in the logistic chain; an expense. The abolition of boards was also supported by advocates of free trade. The Soviet Union's collapse and the related changes in Eastern Europe also led to a reduction of large-scale state-sponsored purchasing. However, the Eastern Bloc were seldom customers to the independent reefer operators since those countries preferred to use their own vessels. Anyway, the main result of the abolition of the marketing boards was the emergence of a plethora of small and medium-sized fruit importers and exporters. There are exceptions besides the aforementioned Zespri; the successor to the New Zealand Apple and Pear Marketing Board (marketing as ENZA) has maintained a large share of exports despite losing its monopoly.

The problem for the reefer operators was that these smallish importers and exporters were in no position to fill a large reefer. Interestingly this occurrence intersects with the advent of oversupply in container capacity and the container lines' consequent advances into the reefer business. The opportunity of shipping a lone reefer container with a container line enabled a small producer to operate as an independent exporter. And for many this was a desirable outcome. The small exporter is however subject to the shipping terms dictated by the large container line. Their smaller volumes also place them in a weaker bargaining position in relation to the major fruit importers and this includes supermarket chains some of which have experienced massive growth over the last decades. The pendulum has swung from a producer-dominated situation, with marketing boards, to one where major buyers can pressure weaker producers. The aforementioned example of the French сів illustrates that even importing boards could be set up very much in the interests of the producers. How have producers responded to the new market situation? One response is that the larger producers, in several countries, have begun to collaborate in terms of marketing and transportation, for example in Morocco. We can summarise the sequence of events as beginning with national marketing boards with compulsory producer membership. These were to a large extent abolished

45 The Citrus Marketing Board of Israel lives on in a reduced capacity. It is mainly concerned with marketing the "Jaffa" brand. 
leading to a fragmented market of smaller actors. Subsequently the larger exporters have in several cases teamed up to form voluntary organisations that to some extent mirror the previously existing marketing boards.

The planned and coordinated imports and exports characteristic of the era of the national marketing boards suited specialised reefer operations. An outcome of their politically sanctioned demise was the emergence of a larger number of smaller-volume exporters. This resulted in a reduced demand for large specialised reefers and a corresponding increased demand for refrigerated containers individually shipped by regular container lines.

\section{Summary}

The fruit companies, and particularly the so-called banana majors, have always played a decisive role for the development of maritime reefer shipping. The size of the banana market and the fruit's intrinsic perishability made the shipment of bananas a challenge that drove technological development, from ventilated carriers to increasingly precise refrigeration, and to modified and controlled atmospheres and their eventual application to containers. Salén was able to leverage their relationship with United Fruit to gain crucial technology in the particular circumstances that prevailed immediately after WW2. From the perspective of the independent reefer operators more broadly, to be associated and do business with the likes of United Fruit or Dole, was to be associated with the biggest and the best in the business. Long-term banana contracts provided the security to finance newbuildings but they were also an indication of market leadership, of subjectively being perceived as a first-class independent operator that could, for example, negotiate with ship-owners and banks from a position of strength and integrity. It is no accident that Salén's and later Cool Carrier's market leadership coincided with their more or less preferred-supplier arrangement with the largest shipper, United Fruits/ Chiquita. Lauritzen likewise developed long-term relationships with these companies, Noboa for example. Star Reefers with its impeccable Blue Star heritage was able to do the same. For others, including NYK, it was a struggle to gain admittance to a rather exclusive club.

The marketing boards were an entirely different kind of shipper. Their emergence, particularly for exports of seasonal fruit, led to growth in a segment that the liner companies found difficult to service. This provided an opening for the wild reefers and led to established relationships between independent reefer operators and many of these boards. Large planned exports, and imports for that matter, were ideal for large dedicated reefers. The subsequent decline of 
the marketing boards, and the defragmentation of the market, led to smaller exporters unable to fill reefers who thus turned to the refrigerated containers that the liner companies, struggling with overcapacity, were expanding into at around the same time. 


\section{PART 4}

Analysis and Conclusions 
Thomas Taro Lennerfors and Peter Birch - 978-90-04-39386-8 Downloaded from Brill.com๑4/26/2023 03:03:15PM via free access 


\title{
The Independent Reefer Operators from Material, Discursive, and Subjective Perspectives
} \\ The Interwar Period: the Birth of the First Independent Reefer \\ Operators
}

The companies active before the Second World War, which we have covered in the book are banana companies such as United Fruit, meat conglomerates such as the Vesteys, including Blue Star Line, and third party shipping companies specializing in reefer cargo such as Lauritzen and Salén. The banana companies had reefer fleets, but these were entirely dedicated to carrying the respective company's cargo - they were in-house logistics departments. Blue Star Line operated reefers, but these were either catering to the Vestey group's internal needs for meat (and dairy) transport or as a complement to Blue Star's established general cargo lines.

What could be called the independent reefer industry was, before the Second World War, very limited. Sven Salén shipped United Fruit's bananas from the Continent to the Northern countries as a third-party shipping company. His company also offered inland transport for bananas, and other fruit. In this period there were still significant challenges for the transport of bananas, and much of the system built up by Salén and Matthiessen tried to solve this transport problem. Salén was an entrepreneur with ambition, an entrepreneur who was not content with being just a link in the logistical chain of United Fruit. In the end of the 1930s, we know that it took the step to order its first purpose built reefer ship in order to start carrying bananas across the Atlantic. The company wanted more.

Lauritzen developed differently than Saléns. Rather than taking the leap from transporting general cargo to transporting bananas as did Saléns, Lauritzen gradually moved into the segment. Given its dry cargo tramping business, it had carried fruit at times, but in the 1920s, it made a calculated decision to avoid tramping. To move its focus towards the fruit trades in the Mediterranean was seen as a good, rational choice, headed by the young generation of Lauritzen. Lauritzen's cargo, for example citrus, was less problematic than bananas and was more common in the Northern countries. One could therefore carefully suggest that forces of logos were dominant in the earliest period of Lauritzen's fruit shipping. Lauritzen originally had an ambiguous relationship 
with the established shipping conferences. Sometimes it participated in them and at other times they were outsiders snapping up cargoes as the opportunities arose.

Soon, however, Lauritzen started to see fruit shipping as one of its core businesses. Given its good reputation as a fruit carrier, Lauritzen was asked to carry bananas long-distance in the 1930s. The first cargo was carried with conventional ventilated fruit carriers, and Lauritzen took considerable pride in managing to successfully transport the cargo from West Africa to France. The banana was, in the 1930s (and onwards), the symbol of reefer shipping excellence. In the 1930s, Lauritzen gained contacts worldwide to transport fruit, including bananas, thereby being in stark contrast with Salén's reefer part which was basically a one-trade business. Part of the desires of Lauritzen, and more especially Ditlev Lauritzen, was to always have a modern fleet, which led to considerable fleet renewal, and many newbuildings of reefers. The thymos of Lauritzen was plausibly related to its quite newly established reputation as a high-quality shipping company, able to carry any kind of fruit including the banana, as well as a shipping company with a very modern fleet.

Materially, the two companies were different. At this time, Salén was still operating its Nordic feeder service with ventilated fruit carriers. The rapid expansion of Lauritzen in contrast with Salén was most probably due to Lauritzen's wider scope of fruit carried, more varied trades, as well as the fact that the company was large, compared to Saléns, and had more resources for new ventures. Not the least was the aggressive fleet renewal policy important. Lauritzen had taken delivery of about eight reefers when Salén's built its first one. It is obvious that Lauritzen was the first company which could really qualify as an independent reefer operator. Carrying reefer cargo was its core business, it had considerable independence from its customers, and it was not owned by a shipper. Lauritzen's banana customers were also smaller players with less, if any, shipping of their own. This may have stimulated Lauritzen's development as a genuinely independent operation. Salén on the other hand were a link in market-leading United Fruit's logistical chain. Shifting our perspective to the general reefer industry, but still taking a material perspective, we know that its history goes back to the late 19th century. Therefore, both Salén and Lauritzen were new, small players compared to the liner companies which shipped significant amounts of refrigerated and frozen cargoes both carried in part-reefers and in dedicated reefers complementing their liner operations. And likewise small compared to the shippers, for example United Fruit's own reefer fleets. The phenomenon of independent reefer operators therefore started as a very marginal phenomenon. 
Regarding the discourses on the level of the general reefer industry, we would like to pay attention to that about the banana. Already since the end of the 19th century, as has been described in chapter 2, there was a quality discourse around the banana, more so than regarding other fruit: It was of utmost importance that the banana arrived to the markets in a good condition. The banana was, and still is, the most sensitive major reefer cargo within the categories of fruit, fish, and meat. Many stories about early specialized reefer shipping were about spoiled bananas arriving at the docks. In other words, the discourses about the sensitivity and perishability of the banana, coupled with the need to deliver bananas in pristine condition provided the discursive background to the subjective forces discussed above. Both Salén and Lauritzen derived pride from being able to carry the banana and the quality discourse trickled into the two companies.

The birth of independent reefer operators mostly stems from the material realities of trans-Atlantic and other long-distance fruit trade. For this purpose, reefer ships were needed. The banana had a particular status amongst the fruit discursively and it was not even seen as a fruit but as a separate cargo category. To be able to carry bananas successfully was a source of pride for the independent reefer operators. The meat trades were often catered for by shippers or by general liners and did not spur the creation of independent reefer operators. At this stage in history, there was no collective, subjective sensemaking amongst for example Salén and Lauritzen to be part of an independent reefer industry. This would change after the Second World War.

1950s: the Wild Reefers

Salén and Lauritzen were the main independent reefer operators in the decade following the Second World War. Indeed, it is in the 10-15 years after the war in which one could say that an industry of independent reefer operators really is established. The most remarkable post-war development is the growth of Saléns.

A complex set of factors led to Salén establishing itself as the leading independent reefer operator. As we already saw in the preceding section, Sven Salén was interested in growing his reefer business, by importing bananas across the Atlantic. He therefore had a will to expand and grow, an entrepreneurial drive of eros. But much of Salén's growth was due to the strategies of United Fruit. They recognized that Salén was a potential strategic partner, not only on the regional but on the global level. He was a partner who was willing to build the tonnage that United Fruit so desperately needed after the losses 
caused by the war. The material base was reduced during the war, which led to a space for tonnage renewal and innovation. However, Saléns lacked the knowhow to build the most modern reefers. Therefore, United Fruits let Salén gain access to the drawings of their latest reefers in the late forties. This instantly put Saléns at the cutting edge of reefer technology. Newbuildings soon followed, and many of these were built in Sweden that had escaped the war with its industry intact. This established an industrial competence in Sweden which served as a resource base for Saléns for decades. The combination of knowhow from United Fruit with the material production capacity of Swedish shipyards was crucial for Saléns. In other words, Salén's was to a large extent a product of the relationship with United Fruit.

Salén positioned itself as a loyal transport provider to United Fruit, but also realized that they should not rely solely on one customer, and therefore developed side businesses with other fruit, fish, and meat. The material and immaterial resources built up in the banana trade could be leveraged in order to expand into other lucrative refrigerated trades. The side business was Salén's way to enter into the specialized reefer industry, where it, thanks to its numerous newbuildings quickly became the main actor. Lauritzen also expanded during the post-War period buying 43 ships from 1945 to 1958, many of which entered the banana and fruit trades. Lauritzen continued to renew its tonnage constantly, given the reduced material base as well as the desire in the company to always have modern tonnage.

Now, these two independent reefer operators started to interact more with the general reefer industry. Both companies broke into the trades that had traditionally been carried by liner conferences. Saléns and Lauritzen could offer more dedicated transports at a good price which suited the exporters and importers of perishables. The combined capacity of the two companies now led fruit exporters to consider the specialized reefers as a viable alternative to liner conferences. In the minds of the customers, the independent reefer industry was established. As we discussed in the introduction, the subjective perceptions of actors are of high importance for what happens in an industry. The birth of the specialized reefer industry is based on this shift of perception from being a set of material artefacts (reefers) which were often tied up in established patterns of trade, the operators had managed to create the perception that there was an independent reefer industry, with several actors such as Salén and Lauritzen but also others like Gustaf Erikson based in Finland.

The whole reefer industry was a small challenger to the established liner companies and saw themselves as being wild, in contrast to the traditional, outdated, and even boring, liner companies. As far as into the 1970s, the inde- 
pendent reefer industry, the part which was not tied up into stable flows of products, such as bananas, was called "wild reefers".

Materially, the companies grew because of the rising demand for the transport of refrigerated products. Part of this growth was absorbed by liner companies, but there were niches which independent reefer operators were quick to fill. The banana companies needed to build up their fleets after the Second World War and used third-party players, such as Salén and Lauritzen. The same discourses reigned over the general reefer industry - the discourse of banana quality. The demands of the banana companies for constantly better transports led to quality improvements at Salén and Lauritzen, who now were in charge of technological development. The large number of newbuildings in combination with the discourse of quality led to incremental changes being incorporated into the ships. Also, the ships became faster which was represented both materially and discursively. The specialized reefer industry saw and talked about themselves as being able to deliver goods to the market more quickly than liner companies, due to fast ships and more direct trading patterns. It is plausible that with the increasing speeds, the discourses about "banana destroyers" - fast, dedicated ships were born here. Yet another material and discursive element which emerged was size. The specialized reefer companies promoted their large refrigerated capacity. So even though they were relatively small vessels, the fact that they were fully refrigerated meant that they could take larger refrigerated cargoes than most liner vessels. Furthermore, liner vessels were tied up in regular trading arrangements, so additional capacity available at any one time was more limited. In contrast, the wild reefer, raced to its destination, frequently in ballast, and could fill the entire ship with the customer's cargo. This was particularly well suited to seasonal trades which was something that kicked-off during the wild reefer era. So the wild reefers were positioned to be able to take large one-off cargoes which is a different style of business than the industrial shipping carried out by both the liner companies and the regular shipments of the major banana companies.

All of the above led to the discourse of the wild reefer, which in a sense is the discourse of the new, small, aggressive competitor, in contrast to old-fashioned liner companies. A fight between David and Goliath. The upstarts were driven by eros, by a will to win and they were thrilled at the prospect of taking on the big guys. They were proud to be the underdog that chipped away at the liners' fruit trades. And Goliath hardly noticed that David was even there.

To sum up this decade, it was the birth of the discourse about the independent reefer industry - consisting of several operators. They were all talked about as fast, large, and wild. All of these discourses were framed in opposition to the characteristics of the prevailing, dominant transport mode - the 
conference lines. The banana companies were still important actors, as they spurred technological development, related to the quality discourse, which led independent reefer operators to constantly renew tonnage, which led to a large base of somewhat older ships suitable for the transport of other fruit, fish, and meat. Subjectively, although there was competition between the independent operators, much of the eros concerned the thrill of breaking into new trades, usually at the liner companies' expense.

\section{1960s: Rationalizations and Explosive Growth}

The 196os were marked by different forms of rationalisation with some degree of incompatibility: boxes, pallets, and containers.

Panama Disease led the banana companies to switch to the resistant but otherwise more fragile Cavendish variety which resulted in the bananas being placed in boxes instead of being shipped in bunches. The problems concerning the banana led to lower profitability, causing banana companies to outsource their capital-intensive fleets. In the late 1960s, Sunkist, which increasingly became a major partner of Salén, wanted to export their produce on pallets as a way to rationalize the handling of cargo. Last but not least, containerization swept through the shipping industry. Container technology for refrigerated products were introduced on a number of lines, but given the cost and difficulties of containerization, liner companies left the refrigerated trades. The replacement of liner tonnage with non-refrigerated container ships caused an important supply shortfall that the independent reefer operators were quick to exploit.

These material changes led to the growth of the independent reefer operators. They were the takers of the outsourced fleets of the banana companies and they could also fill the market gaps left by liner companies which left due to containerization. Although demand of seaborne refrigerated transport grew modestly, Salén's grew explosively and had in the end of the 1960s a fleet of over 100 ships. Lauritzen was significantly smaller, but also grew during the period. Hamburg Süd grew as an independent player with a fleet of about 20 reefers.

This once again led to a change in the subjective perception in and of the specialized reefer industry. They were no longer a wild, eros-driven, alternative to the liner companies, but increasingly became the way to transport refrigerated cargo. They were now of such a large size that they could more adequately be seen as (equal) partners to their customers, rather than their servants. This led to strong sensations of pride across the whole industry, which was one 
way how thymos was represented during the period. Within the industry, the players had different positions. Salén's had become the market leader and prided themselves on their rationalised transport systems and advanced scheduling, including computerized scheduling. They did not just see themselves as the market leader, but as the uncontested market leader, since Lauritzen was less than half the size of Salén. Lauritzen, on the other hand, still saw themselves as a hungry competitor, remembered as "shark's teeth" by one of our sources.

Discourses of large capacity and speed were still prevalent, but to this we must add the increasing sophistication and flexibility of the new ships that were developed, and this had consequences for the specialized reefer industry. Since the players in the specialized reefer industry were no longer a wild alternative, but increasingly became established specialists, able to offer sophisticated services to its customers, Logos entered the stage to a larger extent than previously. Logos meant that the specialized reefer industry should be able to fulfil the customers' expectations to be able to provide low-risk, industrial shipping. And we know that each customer was rationalizing its cargo handling in slightly different ways. This resulted in ship designs that could cater for different cargoes with different requirements. Examples of such flexible ships were the Snow series and the Italian Reefer class, which could handle pallets as well as boxes. Still during this period, the container technology was not incorporated into specialized reefers. In the specialized reefer industry, there was a growing perception that it was the pallet that was going to be the preferred way of handling refrigerated cargo.

1970s: the Others

In the late 196os, Salén was the largest company followed by significantly smaller Lauritzen and Blue Star Line and even though there was competition between them, there was a degree of understanding about the rules of the game. Salén would keep its dominance throughout the decade, while Lauritzen joined forces with $\mathrm{P} \& \mathrm{O}$ to create LPR. The fruit trades were widely perceived as lucrative by the independent reefer operators. Blue Star, for example, expanded its presence in the fruit trades by building the modern A-class in the mid-1970s.

Salén became more professionalized during the 1970 and divisional managers, for example the managers of the reefer division, became more powerful. The trend of rationalization that was started in the 196os, continued into the 1970s. During this decade, independent reefer operators became convinced 
that the pallet was the natural way to unitize refrigerated cargo. They followed the trend of containerization, which was growing, but still thought that the pallet would be preferred amongst customers. Both Salén and LPR worked on optimizing pallet handling. A ship type that was optimized for pallet handling was the Winter class. Despite considerable continuity from the 1960s, the competitive situation amongst the independent reefer operators would change because of some new entrants. The 196os had spurred the interest of companies looking for attractive business opportunities within the reefer segment.

A first entrant was the Israeli company MFC. It represented the first largescale speculative reefer investment in the history of the industry. MFC controlled about 40 reefers, which was about half the size of Salén's fleet, and basically built them to force Salén to charter them. Salén was provoked by this entry which is highly visible in its discourses. MFC was called unknowledgeable, financial, and speculative. Salén claimed that MFC had no understanding of the reefer market, or otherwise they would not have built so many reefers. For a short while, MFC's market entry was successful as they managed to charter their fleet to Saléns and thereby secure income. But for our purpose, this shock to the industry make us understand that there was more or less a controlled situation in the industry before the entry of MFC.

Then, there were the Japanese entrants, such as the fishing companies and NYK. The Japanese entrants were seen by the incumbent companies, in our empirical material mostly from the perspective of Salén, as a radical other. The entry of the Japanese cast a light on the racial constitution of the industry. All reefer companies were controlled by caucasian male managers and employees, who all were internationally minded and of course spoke English. With the entry of the Japanese, there were a new breed of competitors, where possibly only one or a few persons in the organization could speak English. That they further were critiqued for being too competitive and offering too low rates only contributed to this othering.

A third entrant at this stage was Seatrade. It had started out with a single reefer in 1962, but grew towards bigger and more ships. In contrast to Salén and Lauritzen, its main business was fish transport. From the perspective of the incumbent specialized reefer operators, Seatrade was a non-issue because they did not have many ships, the ships were small and therefore of a different kind than the ships that really mattered - the big fruit carriers, and also they were focused on fish, which both Salén and LPR only engaged with as a non-core business. From Seatrade's perspective, the competitors were not really Salén and Lauritzen. A representative of Seatrade even remembers Salén giving away a trade to Seatrade, since Salén was not interested in it. They were indeed in a different segment, but Seatrade knew that it was more profitable to move 
towards larger ships, due to economies of scale. For the moment, the point was just to pragmatically employ the ships as well as possible. The company was doing deals as they appeared and to some extent seemed to lack a strategy. It did not thymotically pride itself by carrying a certain cargo type, like the banana, but similarly to Salén and Lauritzen they took pride in optimizing trade patterns, for example their great Atlantic Circle. They also prided themselves thymotically for being very hands-on and frequently referred to their history of stemming from a group of captain-owners. This stands in contrast to the academic culture that reigned at Salén, where people with good education was sought for. The company was therefore, in contrast to LPR and Saléns, much more engaged in S\&P activities, quickly responding to new opportunities in the market.

The 1970s was the decade of the oil crises and significantly increased bunker costs. The transport cost therefore increased, particularly for ships that had high bunker consumption. This is likely to have favoured new players, such as Seatrade, which could build a business without having to manage a fleet of ships with high fuel consumption. Also, smaller reefers turned out to be even less economically viable than earlier due to lack of economies of scale. But while the smallest ships became bigger, the increases of reefer ship sizes in the largest category also ceased. In all, this led to a situation in the end of the 1970s, where the discourses of "faster" and "bigger" to some extent declined. The Winter class was slightly smaller than the Snow class and also slower. The reefer industry was at a turning point, both due to oversupply of tonnage and due to increased fuel costs. Due to the increased transport costs, banana companies took back part of their fleet into own control, which further increased the number of active players within the industry. Competition therefore went up and the rates were often low due to the oversupply of tonnage. These material conditions can also have impacted on the view of the incumbents on the new entrants, in a sense blaming them for the low market. One could almost say that there is a perception of harmonious competition that changed towards a fierce competition between many new actors that were unknown to each other, such as the Japanese companies, Seatrade, and Laskaridis.

The early 1980 s caused problems for the two major independent operators, Salén and Lauritzen, who was now again a lone-standing organization after P\&O's exit from the reefer segment. Mainly due to problems in other parts of the Salén conglomerate, Salén went into bankruptcy in 1984. As we know, this 
was led by a collective effort to rebuild a new organization. This was not just a process of logical reasoning - that there was a space in the market for a revived operator, but very much a process based on eros and thymos. The former employees all wanted to work for this new organization, not only to secure a new job, but to build something new. To make sense of their actions, they used discourses from war and struggle, describing the office as a command center. When the new company was setup, they were all very proud and happy about the outcome, until the employees realized that they were not part-owners but mere employees. Some of the energy in the organization was lost already there and in the subsequent ownership struggles. But when the market went up, and with a new owner, the organization was once again filled with drives to grow. The people working in Cool Carriers had a strong thymotic feeling of being autonomous - as an organization that was resilient to ownership changes. Cool Carriers' thymos was also linked to its stunning come-back to market leadership, its self-perception of superior expertise, and its perceived control over business partners.

Lauritzen suffered similarly in the early 1980 . It was not hit by a bankruptcy but instead by a report that basically said that the reefer division should be dismantled fully or partly. This was seen as outrageous from the reefer division and also upper management. This gives a sense of what an important part the reefer division was to Lauritzen psychologically. While Lauritzen struggled with red numbers, it adopted the most rational, logos-oriented, way of conducting business - namely to develop a ship type that was fuel-efficient, rational, and which completely abandoned all previous aesthetic ideals of reefer ships - the Jumbo class. To gradually divest non-economic tonnage and invest in more Jumbo ships was seen as the way forward. But top management interfered and created a prestige ship to be used by the reefer division - the Family vessels. On the one hand, this was purely rational, logos-oriented, from a group perspective since it solved the problem of Lauritzen's shipyards. One the other hand, to develop the biggest and most modern reefer in the market, stemmed from the particular thymos of the Lauritzen spirit: to always choose the highquality solution. This conflicted with the logos-orientation of the reefer division. Not the least since all other actors, including Lauritzen's reefer division, was opting for the simple, slower, inexpensive, and rational. The Family class, although appreciated by some at Lauritzen's reefer division was seen as a blow to the agency of the reefer division. When they had just found a way of rationalizing their tonnage, a new kind of uneconomic ship type was entering its fleet. Still, the good market in the end of the 1980s kept the spirits up at Lauritzen. 
Apart from these two operators, Seatrade, which Saléns and Lauritzen saw as more or less insignificant in the 1970s began to make its presence felt. They started to envision growth and larger ships, which resulted in newbuildings, recruitment of personnel and the acquisition of companies. They became proud of their new, highly optimised and rational ships. Furthermore, Seatrade's thymos was highlighted when they acquired of Dammers \& van der Heide in 1989. Seatrade perceived Dammers to be a traditional, hierarchical, high-shipping company in Rotterdam, in total contrast to the hands-on thymotic spirit at Seatrade.

NYK and other Japanese operators continued to have a significant presence in the market. It is interesting to see how they started in the periphery of independent reefer operators, to gradually move closer to the core. They have told us that it was far less prestigious to carry mutton from New Zealand to the Middle East than the large and lucrative banana trades or the trades from South America. Another example that illustrates the problems for the new entrants was Nissui's desired collaboration with Lauritzen and Cool Carriers, but these plans were rejected. Unsurprisingly, they teamed up with another outsider, Seatrade, on a trade from the Canaries. So, although they had a significant fleet, the Japanese companies felt that they, together with Seatrade, were playing in the second division, below that of Cool Carriers and Lauritzen.

The independent reefer operators increasingly aimed for rational, fuel-efficient ships. The discourse of rationality was contrasted with the sleek ships of the past, which disappeared along with the romantic era of the wild reefers. Perhaps there were some concerns about long-term outlook already in the 1980 s, but the overriding belief at the time was that the next decade would be the golden 1990s, with rates of 100 cents per cubic feet. With efficient and rational tonnage, this would all be possible, wouldn't it? This newbuilding boom was the last collective boom of eros witnessed in the reefer industry.

The container lines had been on the independent reefer operators' radar for decades, but it was during the 1990s when they would enter the reefer industry en masse. Several material changes within the industry led to container lines being able to compete against independent reefer operators. The combination of economic liberalisation and the flexibility afforded by containerization resulted in the fragmentation of the market to the benefit of the container lines. Moreover, the national marketing boards lost their importance as shippers and were replaced by direct contacts between buyers and exporters. The 
concurrent emergence of powerful buyers, such as the major supermarket chains, put pressure on both producers and transport providers. They also contributed to the fragmentation of the producer side by directly encouraging smaller exporters which they in turn could exercise considerable control over. There were therefore more shippers, but with smaller volumes, usually insufficient to fill a specialized reefer. The flexibility and low price offered by the container lines were better suited to this market situation.

Cool Carriers were overexposed when the market weakened in the early 199os, but re-embarked on a cautious growth strategy later in the decade. Cool's organization maintained its autonomy despite several ownership changes and this thymotic feature was still a source of pride. These owners were relatively passive since the owners recognized that Cool surpassed them in competence and market know-how. Rather than adopting the textbook owner governance model, that owners control the organization, the discourses at Cool Carriers were that "if we don't like the owner, we find a new one". This was particularly salient in one episode, when NYK was interested in buying Cool Carriers in 1993. The deal could have materialized was it not for the Cool employees, who stated that if NYK would buy Cool, the employees would leave and start a new competing independent reefer operator. Furthermore, the collective trauma and the overcoming of it in the 1980 s led to a strong group culture at Cool Carriers. When a few key employees left in the 199os to work with Seatrade, this led to much frustration as well as a collective will to take revenge, strike back. This is another manifestation of thymos. Also, this episode shows that, finally, Seatrade was a genuine competitor. The thymos was derived from collective autonomy and was still coupled with the pride of being a high-tech market leader with large modern ships servicing high quality customers. Cool Carriers therefore placed their older and smaller tonnage in separate organizations. This pride and prestige was not only perceived internally. For example, respondents from Eastwind stated that their relationship with Cool Carriers gave them legitimacy and status within the industry. Due to the threat of the container lines, many ship-owners planned to exit and offered to sell their ships. Cool Carriers wanted to continue its fleet expansion, and was able to do this somewhat during Höegh's ownership. Nevertheless, Cool was frustrated at the amount of opportunities that they were not able to pursue because of the limitations imposed by its owners.

Lauritzen, on the other hand, was locked into the same ownership structure as in the 1980 s. The reefer division could not produce adequate results, despite its modern tonnage, and was put under pressure. This led to feelings of impotence and resignation. Some people decided to leave the organization to try new ventures, while others stayed and witnessed the division's decline. The 
management knew that the status quo would lead to a gradual decline and exit, and suggested a bolder move - to consolidate with another operator.

Seatrade, as well as Laskaridis, expanded while other companies were scaling back or exiting the industry. Seatrade grew and constructed, bought and sold vessels, and combined this with a will to maximize returns in the operations, under the leadership of its active owners. A former Seatrade employee told us how the company talked about becoming big, that they wanted to become a reputable player on the global stage, "the grand ballroom". This actually contrasted with the company's prevailing discourses about pragmatism and hands-on owner management. Seatrade were happy to expand into the fruit trades, but much of the enthusiasm manifested in interviews with them was about the sheer quantity of fish delivered.

In contrast to Cool Carriers and Lauritzen, NYK had an expansive newbuilding strategy in the 199os. The management of the reefer division believed in the future of the segment despite containerization and managed to convince the upper management of NYK to invest. Still, compared to other segments at NYK, the money invested in reefers was small. The strategy paid off. NYK secured a prestigious contract with Dole, which was a cause of great pride. It also temporarily broke into Lauritzen's Chile trade, which they described with a strong sense of pride. NYK also was in discussions to acquire Cool Carriers. Salén, which had been role model of NYK Reefer, could now be acquired, which was seen as a source of pride. NYK Reefer's fleet peaked in 1995 when it controlled 57 vessels. They became a reputable independent reefer operator due to both its newfound size, its ability to challenge Lauritzen and Cool Carriers, and the solidity of its parent company.

As we have seen, during the 199os the container lines' capacity surpassed that of the specialized reefer companies. Rather than being the way of carrying refrigerated cargo, the liner companies had now resurfaced as an alternative way. During this decade the discourse of "conventional reefers" took off. The independent reefer operators positioned their service, in contrast to that of the container lines, as conventional. In other words, it was not some risky innovation, it was just the service that customers had learned to trust.

We even venture to suggest that the independent reefer operators have been subjected to "container fetishism", which has been visible both in the chapters describing Cool Carriers and Seatrade. Many interviewees have expressed a disdain towards the container. Respondents frequently discuss the container's performance in and by itself, when they are actually discussing the real threat - the threat of the competition from the container lines. We would therefore venture to say that the reefer companies have centered their perceptions on the container as a representation of the large shipping lines, thereby 
condensing a larger issue on one material artifact, which would be similar to fetishism. The importance of containers for reefer operators has been discursively peripheral, even though reefer companies have been placing containers on the weather deck since the 1970s. Therefore, the reefer companies have been negating the container, positioning themselves as an alternative to container technology, rather than positioning themselves as an alternative to the container lines. With a bit of a drier approach, one could state that it is not strange that so much has been focused on the container. The very possibility of the container lines being able to compete with the reefer companies depended significantly on the technological development of the reefer container. And in the beginning, the reefer container did not deliver the service quality of a non-containerized reefer ship. It is similar to many other technological shifts, where the new technology is in the beginning inferior to the prevailing alternative ${ }^{1}$. This misperception, or at least the discourse of container fetishism, was so widespread that Mats Jansson of Cool Carriers needed to emphasise in the late 1990s that the race was not between the container and the non-containerized cargo (see chapter 5 ). It was between the independent reefer operators and the container lines. This line of reasoning was also later picked up by Seatrade when the point was to find a competitive edge for the independent reefer operators. And this could hardly be found in just being "the conventional alternative". But the discourse of the conventional reefer was spreading at the same time and even during our empirical research in 2013-2016, respondents had to stop themselves from saying the word "conventional", instead of "specialized".

In the 2000s, the container lines aggressively competed for refrigerated cargo and rapidly added container capacity. However, this negatively impacted on the independent reefer operators and resulted in a wave of consolidations.

Lauritzen acquired Cool Carriers in 2000 and merged the operations, but stated explicitly that it would not invest in tonnage. Still, many felt that this was a new beginning, something which was felt with almost every new owner of Cool Carriers. A respondent stated that "it started to feel exciting again". The upper management had several ideas for newbuilding projects but all projects were declined by Lauritzen's board. This stifled the drives of the company, since the eros and thymos could not be satisfied in the present setup. We know

1 Christensen, C. 1997. The Innovator's Dilemma: when new technologies cause great firms to fail, Boston, Mass. : Harvard Business School. 
that LauritzenCool, through Mats Jansson and others, tried to avoid container fetishism and instead started to talk about themselves as experts in refrigerated transport; the discourse shifted from reefers to logistics. Building on Lauritzen's previous success in Chile, they started a global door-to-door service called LCL, expanding vertically in the value chain, with no clear preference for shipping the refrigerated cargo in containers or not. This development can also be linked to the broader discourse of logistics that became prevalent at the same time. For LauritzenCool it was a potential solution to the contradictory sitution of being financially constrained while battling to maintain market leadership.

NYK Reefer was struggling in the end of the 1990s and decided to relocate to the core of the industry in North-Western Europe. NYK Reefer had become part of the establishment and also built up a pool of human resources that was more international, which to some extent reduced the Japaneseness of the company. When it set up NYKStar, the joint venture with Star, it was deemed important that the nature of the two companies was similar - they were both owned by traditional liner companies. However, Blue Star Line's Star Reefers was acquired by Christian Siem, who was seen by the incumbent reefer operators as a short-term speculative investor. This could be related to Siem's past as a successful investor, but also resonates with the attitudes of the independent reefer operators towards newcomers. Siem was definitively not one of the old boys. Despite that the conditions for a successful partnership had changed, both parties pressed ahead with the joint venture that became NYKStar. Siem was focused on developing his new investment which, it is claimed, caused the NYK side to take measures to ensure that they were not disadvantaged. For example, Lars Rutberg from Salén and Cool Carriers was recruited to help NYK protect their interests. The inability of the two sides to work together resulted in the joint venture being dismantled and NYK looked to LauritzenCool as a potential consolidation partner.

As a first step the relationship concerned tonnage sharing, but NYK Reefers subsequently bought $50 \%$ of LauritzenCool and LCL. The strategy for these owners was to consolidate their operations, minimise their fleets, and focus on stable contracts with major fruit companies. Therefore, the ReeferShip venture with its older ships was dismantled. This is not only connected to a rational strategy that more money can be made with modern ships. It can also be seen as thymos - the organization's drive to be the highest quality operator in the field. NYKLauritzenCool was no longer the largest independent reefer operator - Seatrade was - but strived to be perceived as the best one. NYK bought the remaining $50 \%$ in 2007 and the company was renamed NYKCool. When NYK had entered as new owners in 2004, the management saw a new chance to 
develop the business and do some newbuildings, but these desires could not be fulfilled. Similarly, they felt that they missed many good second-hand deals because of the new owners' lack of expansive ambitions. Cool Carriers which had until Lauritzen entered the scene seen themselves as autonomous was now subject to what they saw as the slow decision making of NYK. This led to the mobilization of stereotypes, both racial and cultural, about the Japanese, and about NYK in particular. At the same time, they knew that NYK had survived for more than a century, possibly because of this structure. NYK didn't allow any newbuildings, but allowed LCL to keep expanding and also approved a major financial deal with Chiquita. However, both of these businesses turned to disaster partly because of the financial crisis in 2008. As a result of these setbacks, the Japanese parent company wanted the Stockholm operation to focus on maritime reefer operations. The locus of strategy was moved away from NYKCool, and there was a significant feeling of decline in the organization. Ships were sold, people made redundant. In 2014, the company was sold to Baltic Shipping.

After the end of the relationship with NYK in 2002, Star Reefers built on their relationship to a Japanese ship-owner, which in turn had ties to a Japanese shipyard. This led to the construction of 12 state-of-the-art hybrid reefer ships - the largest investment in reefer newbuildings so far in the $21^{\text {st }}$ century. Star grew its fleet but after the economic crisis in 2008 consolidated by scrapping its older vessels. Star is proud of its modern fleet and its contracts to the major fruit companies, but its strategy is governed by logos - to be a long-term reefer tonnage provider.

Seatrade continued expanding in the 2ooos buying second-hand ships and ordering newbuildings in Japan. After a short period of turbulence, Geert Pepping emerged as the owner of Seatrade. In spring 2010 Seatrade created a pool of small vessels together with Laskaradis' Alpha Reefer pool and Green Reefers as a means to consolidate in a weak market. After a successful policy to scrap ships, the market rates improved and the two parties felt that they were better off going alone. Green Reefers continued to jointly operate with Seatrade while Laskaradis and Seatrade cut all their ties.

Seatrade has become the only remaining large independent reefer operator. They have embarked on a program of converting its reefer fleet to reefer-container vessels and are unique amongst the independent reefer operators in promoting full containerization. Seatrade have tried to convince customers to use reefer containers and promoted the quality of the reefer container. They have even constructed a meeting room in their head office out of the internal walls of a reefer container - symbolizing its focus on containerization. From the perspective of those companies now owning break-bulk reefers and still 
tied up in the discourse of container fetishism, Seatrade is moving to the dark side, educating customers in forbidden knowledge, since the message of the independent reefer companies has always been that the container is inferior to break-bulk reefers. Seatrade is thus positioning themselves as a company that offers a service different from the container lines. Casting aside container fetishism, they have returned to the original role of the independent reefer operators - providing direct maritime links with state-of-the-art technology. Its fleet renewal may also improve the company's ability to attract investment and the adoption of the dominant design of reefer shipping - container ships - increases the returns that the company could expect if it were, hypothetically, to exit the industry at some point in the future. Many wonder whether Seatrade will be able to compete, only the future can tell. 


\section{Snow in the Tropics: Conclusions}

The aim of this book was to describe and explain the individual and collective development of the independent reefer operators in their material, discursive, and subjective dimensions.

Collectively, the independent reefer operators, such as Lauritzen and Salén, started out in a minor niche dedicated to transporting bananas and other fruit, then grew into becoming a stand-alone, independent industry in the 1950s and 1960s. While the competitive situation within the independent reefer operators was oligopolistic in the 1950 s and 1960s, new actors entered in the 1970s, such as Seatrade and NYK. After a short boom in the end of the 1980s, the liner companies, now fully containerized and interested in expanding in reefer cargo, came back in full force, and the independent reefer operators' controlled capacity peaked and started to decline. Throughout the 1990s and 200os, consolidations have been the norm. Regarding the industry structure of the independent reefer operators, there is a clear pattern. In the early phases, until the late 1950s, there was competition between a number of smaller operators, such as Lauritzen, Salén, and Gustaf Erikson. From the late 196os to the mid-198os, concurrent with a growth of the segment, Salén established a dominant position, controlling twice or three times the tonnage of the second-largest player. From the mid-1980s to the late 199os, when the capacity of the independent reefer operators peaked, several actors competed for industry supremacy, amongst them Cool Carriers, Lauritzen, Seatrade, and Chiquita's independent operation the Great White Fleet. Since the year 2000, when the capacity of the industry has contracted, the competitive situation looks very much like that from the late 1960s to the mid 1980s, with one very dominant operator and a few smaller players. But it is not Salén, but Seatrade, which dominates the now reduced industry.

By applying our theoretical framework, our description has been informed by three dimensions: the material, the discursive and the subjective.

The material dimension strongly resonates with established scholarship in maritime history. From this perspective, we have described development of trades, ships, and companies. We have covered how operators developed larger 
and faster ships until the oil crises in the 1970 and onwards focused on more optimized and fuel-efficient designs. Furthermore, their competitive edge was to have refrigerated capacity dedicated to customers' needs. They had capacity to take exporters' cargo and take it to the destination faster than the liner conferences. In this conclusion, we will discuss why different reefer operators have grown, stagnated, or left the industry. In general, similar factors as those identified for other kinds of shipping companies apply here. For example, the importance of dedicated, active ownership. Seatrade, which has been the prime example of having successful active ownership, only really stumbled on one occasion, and that was when the ownership structure was changed. Imagine then a company like Cool Carriers with its succession of ownership changes it is certain that the ownership changes negatively affected the development of the company. Why is ownership important? Owners always have a potential locus of strategy and they can choose to exercise it to a greater or lesser extent. For example, the fact that Seatrade has grown to become the biggest operator, while Cool Carriers has declined, is difficult to explain by the differences in know-how and business acumen in the two organizations only. Rather, Seatrade's owners, compared to most of those of Cool Carriers, were interested in growing the business. Lauritzen have also had long-term owners, but the owners were during the past decades interested in other segments, given the low profitability and perceived dull prospects of the reefer segment. The conclusion to be drawn is that if owners are committed to staying and growing in the reefer segment, they will do so, of course depending on their financial means, know-how, and their business success. However, the management and organization's ideas, interest, and know-how do not suffice if they do not have the full support of the owners. The cases of Lauritzen in the 1990s and Cool Carriers throughout the 1990s and 200os exemplify this conclusion.

Furthermore, in the reefer industry, similarly to other segments of the shipping industry, quick decision-making is seen as essential, particularly with regards to Sales \& Purchase deals. A close relation between the owners and the upper management of the independent reefer operator is considered to be crucial. Seatrade and Laskarides are, and Lauritzen and Salén in early phases were, benefitting from being strongly owner-managed. They could rapidly, within days or hours, make sales or purchase calls. The contrast to companies where ownership and management is more separated is clear. Cool Carriers, in its various guises, often reportedly missed deals due to slower response from the owners, which in turn was due to lacking interest in investing in the reefer segment. Why is Sales \& Purchase important for a reefer operator? Much of the profitability of the operation of a shipping business is dependent on that ships are purchased at an attractive price compared to the current market rates. The 
price paid for a ship trickles down to yearly depreciations, which is a significant part of the expenses of a shipping operation. Good Sales \& Purchase activities therefore create the conditions of business success. Since the shipping industry is markedly cyclical, the timing of making investments is crucial. A ship-owner once told us that if you buy a ship too expensively, you will pay for your mistake for decades to come. The adage of buying when the market is low and selling when it is high is repeated by all operators and ship-owners. Those companies who manage to do it attribute their success to a variety of reasons: better analytical skills, a gut feeling for the market, or luck. Ship investment is a risky business, a little like gambling, which we are of course not the first to point out. Another aspect of ship investment is the construction of new vessels. Newbuildings require the ability to mobilize resources and, once again, the role of ownership is important. The ultimate success of newbuildings is also linked to the relationships to customers, shipyards, and the know-how within the organization. In turn, constructing new vessels generates additional know-how, particularly for companies that are actively engaged in the newbuilding process. Newbuildings are thus a way to maintain one's place at the cutting-edge of innovation within shipping. Respondents have said that if you don't build ships regularly, you will have a tough time when you want to build one. The decline of reefer newbuildings in recent years results in a decline of competence.

While we have focused on ship investment until now, the other side of the coin for the independent operators is the successful day-to-day operation of the ships. A good operation needs to cater for the various stakeholders such as customers and ship-owners. To the customers, the operators need to deliver the shippers' goods to the right place, at the right time, at the right price, and given the perishability of the cargo in the reefer industry, in the right condition. Continued operational success can spur shippers to commit to the independent reefer operator on the medium or long term, which provides the base for tonnage expansion. In the case of Salén, the main customer United Fruit even supported Salén's technological know-how significantly.

The independent reefer operators must also cater for the ship-owners' needs. They must therefore demonstrate that it will be profitable for the shipowners to place their ships in this operator's pool. Data of outperforming competitors, an image of professionalism, a thorough market know-how, and that the operator is delivering quality to the shippers might convince ship-owners to allocate their ships to a particular operator. Trust in an independent operator to be profitable is therefore of importance for attracting ship-owners. Furthermore, an operator handles the tonnage of several owners. Therefore, a constant issue that has crept up in our data is that of fairness and justice, or 
ethics if you will. The question each ship-owner asks is: am I paid a fair price for my ship in relation to the price that is paid to other ship-owners? This issue is important when it comes to the relation between various ship-owners with ships in an independent operator's pool but becomes even more salient when the independent reefer operator has its own ships in the pool - since the other ship-owners will suspect that the operators are favouring their own ships. The various independent reefer operators have constructed their own systems with trade formulas complemented with negotiations with ship-owners to try to please all parties. It is interesting, from a more subjective perspective, that all independent operators see their own way of handling these ethical issues as superior to those of the others. Ethics, or at least the perception of it, is a success factor for independent reefer operators. A good reputation also means that brokers and other actors will know about the operator, potentially bringing ship deals and new contracts before turning to others, following the wordof-mouth logic.

The independent reefer operators need to mobilize the resources of other companies but aim to maintain control over their operations. Reefer operators want to attract ship-owners that commit ships but don't interfere in day-to-day operations. In other words, the locus of agency is kept by the independent reefer operator. When Seatrade mobilized resources from its local Groningen cluster, or when Lauritzen mobilized funds from Drammen Shipyard, or when Salén made use of Japanese trading houses to finance ships, they all followed this model - to expand the fleet while maintaining control. One of our respondents, who incidentally sees himself as a competent ship-owner, has even said, to provoke, that the independent reefer operators thrive on "stupid" ship-owners. On the other hand, fleet expansion resulting from the merger of two independent operators, have often led to problems due to conflicting loci of strategy, for example the short-lived collaborations Hamburg Reefer Chartering and NYKStar. In any case, the ability to mobilize resources and maintain control is a main competitive factor amongst the operators.

We would also like to problematize the concept of success in the reefer industry. From our empirical narratives it is clear that Salén grew to become the largest operator in the mid-196os, followed by Seatrade which since the 1990s has been the largest operator. These two companies could therefore be alleged to be the most successful companies in their respective time periods. However, size is not all. A successful operator can also be a company that, without any spectacular growth, generates profits to its owners. Data about profitability is unfortunately lacking in our study, and this is because most of the industry's value is connected to ship-owning, and this information is by its nature elu- 
sive. Also, companies who made a timely exit from the industry, may be considered to be successful.

However, when a company controls significant resources, such as Salén did and Seatrade does, it has more leeway to try out things and experiment with their business models, with a controlled risk level. This has been observed both in the cases of Salén and Seatrade. For example, dealing with the macro trend of containerization, in the early 1980s, Salén bought two reefer container vessels that were operating on a service with Dole. Seatrade has embarked upon a fleet replacement program that consists of new reefer container vessels. Moreover, due to the few newbuildings of reefer vessels, fewer shipyards are interested in building reefer vessels. Many shipyards are interested in building longer series of ships than just a few reefers. The most recent examples of long series of reefer vessels covered in this book is that of Shikoku Shipyard's newbuildings for Star and Danyard's newbuildings for Lauritzen and other fruit companies. Currently, the price of non-containerized reefer vessels would likely be higher than for reefer container vessels, even including the price of containers. And the second-hand market is better than for a non-containerized reefer vessel.

Also, the fruit companies, such as Dole and Chiquita, have already moved to fully containerized reefers on some trades since the 1970 . Seen in this way, Seatrade is a latecomer, but still more advanced than the other operators. But on the other hand, Seatrade is the only independent reefer operator who was able to renew its fleet in this way. Cool Carriers' last owner NYK was definitively on its way towards a controlled exit, and Baltic Shipping's intentions with Cool are unclear, so Cool Carriers was unable to take any fleet renewal initiatives. Star is embedded in a system with state-of-the-art non-fully-containerized vessels, since they have a customer demand and this coincides with what the Shikoku Shipyard wants to build. Green Reefers and Seatrade's fish transportation business have renewed their fleet with new freezers for fish transshipments, of course not containerized. In other words, Seatrade is not testing anything new, since the fruit companies have used reefer container vessels since the early 1970s. Rather, they are now following the trend of containerization and are fighting to maintain a niche for independent specialized reefer operations. Seen in this light, Seatrade is the most advanced reefer operator, but in a quite backwards industry.

Taking a long perspective, we could compare this with the low technological maturity of reefer operators, such as Lauritzen, in the 1930s, when they operated ventilated fruit carriers, while shippers such as United Fruit had operated reefers for around 30 years. What pushed the technological leap for Lauritzen and others was the physical demands of the cross-Atlantic trades, which 
required reefer vessels. At the moment, it is the macro trend of containerization which pushes reefer operators to change and the maritime link cannot be conceived without looking at the rest of the cold chain. Inland transport, particularly in the us and Europe, is containerized. Port operations, particularly in the consumption markets are becoming increasingly containerized. Terminal operations are also moving towards containerization, which leads to the disapperance of cold storages, since containers have their own integrated cooling machinery. Furthermore, container ships have become the dominant design at the shipyards and this creates an additional barrier towards the construction of new non-containerized specialized reefers.

As has been described, the independent reefer operators are a part of the cold chain's maritime link but their function can also be catered for by shippers and liner companies. Shippers and liner companies have influenced the development of independent reefer operators in various ways. In the early years it was the shippers - the meat companies and banana companies - that led the development. They had no choice but to establish a maritime link for their products and to do that they had to build specialized ships, ships that did not exist at the time. As new exporters and importers entered, opportunities emerged for independent operators to meet their transport needs. The irregularities of the fruit trades were also an opportunity that liner companies were ill suited to cater for. The establishment of independent reefer operators meant that the shippers were no longer obliged to completely control the maritime link. Outsourcing their shipping requirement became an option and this is what United Fruit did when they educated Salén in building modern ships. Up until the 196os, the liner companies were carrying a fair share of cold and frozen goods. The advent of containerization changed this. The difficulties with refrigerated containerization meant that liner companies lost most of their refrigerated cargo to the independent operators, resulting in a boom which lasted for decades. As the liner companies gradually sorted out the difficulties with refrigerated containerization, they increased their market share at the expense of independent reefer operators.

Independent reefer operators and exporters had a long-standing relationship, and their businesses were well suited to each other. The business of perishables was largely in the hand of exporters, who transported large quantities in dedicated reefers. This formed the core of the industrial logic, at least up until the 1980s. However, exporters are not as powerful as they used to be. There is no player on the banana market that is as dominant as United Fruit was in the past. Similarly, the decline of export boards has fragmented the market resulting in more, but weaker fruit exporters. Smaller exporters do not require a dedicated ship and prefer to ship their goods with liner companies. 
The reason for the weakened power of exporters is that the power of importers, particularly supermarket chains, has increased. Supermarkets have different priorities and this cascades down and changes the industrial logic of the maritime link. They are interested in importing goods in smaller quantities more frequently, just-in-time if you will, which favours the regular delivery of containers.

Moreover, the increasing competition between supermarkets leads to a regime of cost-cutting which impacts on both fruit exporters and shipping companies. Supermarkets have therefore questioned the value of branded fruit, and have looked to create their own supply, possibly using private labels. This spiralling competition creates new actors that try and undercut major brands like Dole, Chiquita, DelMonte, and Zespri, brands that traditionally were shipped to the market in dedicated reefers. The traditional industrial logic of exporters and dedicated reefers still prevails within the banana segment and this is due to the cargo's perishability and the fact that the major banana companies still try to control the maritime link for their own production.

We have shown that the indepedent reefer operators are particularly tied to an industrial logic which is being replaced. This begs the question: what will the future look like for the reefer operators? In some segments, such as transporting fish and seafood from fishing grounds to ports, as long as the fishing fleet is too valuable to remove from its core activity - fishing - reefers, or rather freezers, will most probably continue to exist. In other port-to-port operations, specialized reefers will exist as long as there is a demand by exporters to get their produce to the market quickly and as long as container lines cannot handle the peaks in the season shifts. But as we know, the power of exporters is decreasing. Another important niche for independent reefer operators stems from seasonality. Given the seasonal nature of reefer cargo, there will be a need for reefer tonnage in the high season, since the capacity is just not enough on liner vessels. As it has been for decades, the specialized reefer operators carry branded fruit from the exporters to the market faster than what the liner companies can. The question remains open whether customers will be prepared to pay a premium for the "taxi service" when there is a regime of cost-cutting prevalent in the market place.

\section{The Discursive Dimension}

Turning away from the material, it has been productive to take a discursive view of the industry. In a sense, the segment of independent reefer operators was born by means of discourse. Rather than being just a few companies 
engaging in material practices, in other words, transporting reefer cargo, the companies started to talk about themselves as independent reefer operators and a new segment was established. The discourse of wild reefers positioned the independent reefer operators in opposition to the liner companies, being fast rather than slow, dedicated rather than serving all, and being modern rather than conservative. Also, the industry was influenced by discourses of inclusion and exclusion, for example by the incumbent Salén when newcomers arrived in the 196os and 1970s, and by the incumbent reefer operators when Christian Siem appeared on the reefer scene. The consequence of this discourse was that it became difficult for newcomers to enter into collaborative relations with established parties, which led them to seek to collaborate with other newcomers. Other examples of discourses are more company specific. They concern how the different actors distinguish themselves from the others, as being the established market leader such as Salén and Cool Carriers, the smaller high-quality, aggressive champion such as Lauritzen, or the hands-on, down-to-earth anti-establishment newcomer such as Seatrade. Another important discourse is how the various companies that we have studied are described in terms of stereotypical attributes of their nationality. Nationalist, or racial, discourses are widespread, and attributes such as arrogance, greediness, collectivism, are strongly related to nationalities. Such discursive framings have had impact on the actions of companies and the images of companies that are created by means of such discourses have no doubt influenced the trust given to them by investors, financiers, and others who wield resources. Greedy Dutch and the black-hair meetings of the Japanese.

However, the most salient discourses that have influenced the industry in recent decades have been container fetishism and a discourse of decline. The former framed reefers as not being primarily involved with transport using containers. The fetishism concerned boiling down a difference in business models to a material artefact - the container - similarly to how the shoe becomes a fetish of sexual attraction. The emergence of this discourse can very well be related to the discourse of wild reefers, which contrasted the reefer operators starkly from the liner companies, thereby leading to a hesitation amongst reefer operator to undergo the same technological paradigm shift as their main competitors had done. The discourse of container fetishism was important and could have delayed full containerization of the independent reefer operators for a decade, or more.

The discourse of decline - in other words that independent reefer operators are collectively in decline and will continue declining - is very dominant within the industry. It has been ongoing at least since the mid-1980s, even though the peak of reefer tonnage was in the early 199os. At first sight, it is not 
surprising that such a discourse exists. In terms of capacity, there has been decline since the mid-199os. Also, many respondents have told us that the fact that Seatrade is the only large actor left is a sign of decline. But, the fact that Seatrade is the only major player is hardly a new phenomenon. As explained above, Salén was by far the dominant player during some decades in the past. Also, although many see declining industries as less than interesting, reefer operators have told us that the decline can still lead to profitable business. For example, Thanassis Laskaridis said: "You could call [the reefer trade] a business in a run-off mode, but it is a slow, profitable run-off"1. Taken one step further, one could even argue that the discourse of decline is something which makes the industry less attractive for potential investors. This interestingly hinders the possibilities of expansion for established actors within the industry, as capital is scarce, but it also keeps profitability up by not spurring new entrants to try their luck. Historically, there have been several phases where new entrants, such as the late 196os and early 1970 s and the late 1980s, spurred by interest in the segment, contributed to lowering market rates by creating an oversupply of tonnage. To reduce the attractiveness of such actions, a discourse of decline can actually be helpful.

From a subjective perspective, we have seen that many strategic actions in the industry have been shaped by the force of logos - a rational, calculating attitude. This force is to some extent present in all business decisions, which goes in line with the literature on strategy. For example, many reefer operators have expanded into larger and larger vessels to reap the benefits of economies of scale. However, there was always concern about whether there would be enough cargo to fill the ship. This trade-off between the decreased cost per transported unit and the risk of not filling the ship, was reasoned, discussed, and argued in all companies. The buying of ships, market expansions, consolidations, and exits are all created by thoughts about what the future is for the segment and the prospects of one's participation in it. However, given our theoretical concepts, there are also parts of thymos and eros in business decisions.

Thymos - the sense of pride, courage, and spiritedness - appears concerning the identity of the companies, for example the pride of Salén in the 1970s and 1980 s and Cool Carriers to be the market-leader, the most rational and systematized company. Salén was also very proud of its relationships to United

1 "Going in for the krill". TradeWinds 23 May 2014. 
Fruits and United Brands, which was the number one banana company in the world. A respondent from Salén said that "there was us up here", holding his hand above his head, and then slowly lowering his hand to below the table and then, when reaching a really low level, saying "and the others were here". There is even a sign that the Five saw Cool Carriers as the Rolex of the reefer industry. Such attitudes have affected business decisions, such as turning down potential collaborations, as well as not paying enough attention to the growing competitor in the Netherlands. Interestingly, feelings of industry superiority tend to stick even though the material conditions are changing. Cool Carriers was slowly declining but still they perceived themselves to be the best. It is possible that the subjective is less malleable than the material, although it might seem more ephemeral and fleeting.

Thymos is very present in the discourses and practices of the newcomers, especially in their will to grow larger and better than the previous incumbents. NYK's journey from what they saw as second-tier customers to getting contracts with Dole was as much a story of business development as one of the pride of increasing their social status. Some companies seemingly lack notions of pride. Some actors have explained how, in contrast to the proud Cool Carriers, they were down-to-earth and only focused on the rational pursuit of profits. However, when telling us about this, they did not express this fact in a cool, rational way, but rather seemingly derived pleasure from their down-to-earth identity. The opposite is perhaps Lauritzen, identifying with Danish design and spick-and-span looking ships. One Lauritzen respondent compared his own ships with a competitors' and said: "Those pictures are photoshopped. In fact, the ships look like shit". Also, when we discussed reefer business with a Japanese ship-owner, he stated that he was very proud of his reefers, and would not trade them away for car carriers, which look like shoe boxes, or any other ship type.

Eros - this very complex concept embodying connotations such as excitement, fun, urges, thrill - is a driver in the shipping business, an aspect frequently neglected. Respondents from growing companies, such as Salén in the 1960 and 1970s, talk about the thrill of being in an organization that was growing exponentially: "We were everywhere. We were the biggest. We developed new sophisticated ship-types." The Christmas of 1984; collective effervescence drove the people at Saléns to arise from bankruptcy as Cool Carriers. However, when the ambitions of the employees and upper management of Cool Carriers were stifled over and over again, the will to fight, the will to dream and desire, faded away. Seatrade tries new ideas and is described as intuitive, meaning that the distance from thought to materialization was short. People could live out their ideas, get listened to, and feel that this was a company that was 
well-worth working for. To keep these drives alive in a company is important. For many people in shipping, the ultimate manifestation of eros is the drive to own ships, particularly big, modern vessels. "Everybody wants to be a shipowner", as one of our respondents put it.

Not only in the case of Cool Carriers, but more importantly at Lauritzen in the 1990s, we have seen the consequences of stifling employees' desires and thrill. People who were there were dissatisfied and felt that the working climate was not about work but about politics. Many employees had ideas, but since they couldn't be materialized within Lauritzen, they left to join others. In other words, the thrill of growing one's business, the thrill of acquiring a ship or a competitor, the thrill of becoming great again, and not the least the frustration when one cannot satisfy one's desire for excitement, have all influenced the development of the segment. Given the strong discourse of decline from the 1980 s and onwards, many of our respondents, apart from those at Seatrade, feel a bit at a loss. They cannot live out their eros, but rather stay afloat and subsist in work places, sometimes dubbed by a respondent as "reefer refugee camps".

In this book, we have paid particular attention to the discursive and the subjective dimensions, as well as the material dimensions that are usually covered in similar works. It is common in today's business scholarship to narrow down one's research to follow for example the material turn or the discursive turn. Although we are very sympathetic to such research, we believe that these turns could be even more productive if they would combine several such aspects. By adopting three dimensions, we do not run as large a risk of forgetting important facets of the industry, but on the other hand, the findings do not become as well-defined and neat. Since we try to include all three dimensions, one might also wonder how they interrelate and if some dimension is more important than others.

As stated, much of the actions and strategies of the different actors can be explained by focusing solely on the material dimension. However, we have shown that discourses, for example that of container fetishism, have affected the industry. A description of the industry focusing on the 1980 s and $1990 \mathrm{~s}$ which does not include container fetishism would therefore be insufficient. If one would only have focused on the material dimensions, it would have been much more difficult to identify such discourses. To appreciate the material dimensions, one has to go beyond figures when analysing an industry and pay attention to how the industry is discussed, how it is expressed, and not only 
take discourses as representations of reality. Furthermore, interview data can also be valuable for identifying discourses, as it gives first-hand insight into how the industry is talked about, in a sometimes more uncensored way than what appears in annual reports and industry trade papers. The subjective perspective, has for us emerged methodologically by thinking thorougly about interview data, not the least emotions, silence, laughter, cynicism, in relation to the material and the discursive. With the subjective dimension we get closer to what the actors really want and do not want, as well as what enjoyment and frustrations they express. For example, annual reports might say that there is a need to consolidate and that the parties look forward to the consolidation, but do the involved actors want to do it? Or, that a particular ship type, which from some perspectives, and particularly in newspaper articles and corporate speech is seen as the reefer ship of the future - in other words the Family class - by many was perceived with great frustration and rather seen as an obstacle to creating that very future. By paying attention to what lies between the lines, people's subjective attitudes in relation to discourses, what remains unsaid and so on, we believe that we can throw additional perspectives that are not always visible with a more conventional theoretical framing, and an exclusive use of archival methods.

Let us return to the cornucopia in the supermarket. We've read about the drama, the struggles of the independent operators and the liner companies, the entrepreneurship and innovation, the discourses about the good, the bad and the ugly, and the psychological struggle between the rational, the affective, and the libidinous, which are all embodied in that simple, innocuous banana. To be able to enjoy the tropics in a place far away, even in the snow, then there is a need for snow in the tropics - a well functioning cold chain, the maritime part of which has been serviced by the independent reefer operators, with ship types such as the Snows, the Winters, and the Ices. 
Thomas Taro Lennerfors and Peter Birch - 978-90-04-39386-8 Downloaded from Brill.com๑4/26/2023 03:03:15PM via free access 


\section{Bibliography}

Adams, F.U. 1914. Conquest of the Tropics: The story of the Creative Enterprises conducted by the United Fruit Company, New York: Doubleday. Page \& Company.

Arduino, G., Murillo, D.C and Parola, F. 2013. Refrigerated container versus bulk: evidence from the banana cold chain, Maritime Policy \& Management, 42:1-18.

Arduino, G. and Parola, F. 2010. Cold Chain in the Shipping Industry: Bulk versus Container in the Banana Trade, 12th World Conference on Transport Research, July 11-15, 2010 - Lisbon, Portugal.

Badiou, A. 2005. Being and Event, New York: Continuum.

Badiou, A. 2009a. Logics of Worlds, London: Continuum.

Badiou, A. 20ogb. Theory of the Subject, London: Continuum.

Bakka, D. Jr. 1997. Höegh: shipping through cycles 1927-1997, Oslo : Leif Höegh \& Co Asa.

Baraldi, E., Gressetvold, E., and Harrison, D. 2012. Resource interaction in inter-organizational networks: Foundations, comparison, and a research agenda. Journal of Business Research, 65: 266-276.

Barney, J. 1986. Strategic factor markets: Expectations, luck and business strategy. Management science, 32: 1231-1241.

Barney, J. 1991. Firm resources and sustained competitive advantage. Journal of management, 17: 99-120.

Bjorgolfsson T. 2014. Billions to Bust - and Back, London: Profile Books.

Boje, D. 1991. The storytelling organization: A study of story performance in an officesupply firm. Administrative science quarterly, 3: 106-126.

Borgen, P.O. and Heieren, R. 2011. Made in Drammen : industrihistorie fra en østlandsby med hovedvekt på perioden 1870-1970, Drammen: Drammen Rotary, Available at: <https://www.drammen.kommune.no/Books/made\%2oin\%2odrammen/files/as sets/basic-html/index.html\#page1>.

Boyes, R. 2009. Meltdown Iceland, London: Bloomsbury.

Branch, A. 1998. Maritime Economics: Management and Marketing, New York: Routledge.

Burley, K. 1968. British Shipping and Australia 1920-1939, Massachusetts: Cambridge University Press.

Carlisle, R. 1981. Sovereignty for Sale: The Origins and Evolution of the Panamanian and Liberian Flags of Convenience, Maryland: Annapolis.

Christensen, C. 1997. The Innovator's Dilemma: when new technologies cause great firms to fail, Boston, Mass. : Harvard Business School.

Cohen, R. 2012. The Fish that Ate the Whale: The Life and Times of America's Banana King, New York: Random House.

Collard, I. 2014. Blue Star Line: Fleet \& History, Gloucestershire: Amberley Books. 
Critchell, J. and Raymond, J. 1912. A history of the frozen meat trade, an account of the development and present day methods of preparation, transportation, and marketing of frozen and chilled meats, $2^{\text {nd }} \mathrm{ed}$, London: Constable \& Company.

Czarniawska, B. 1998. A Narrative Approach to Organization Studies, London: Sage.

de Jong, A., Higgins, D.M. and van Driel, H. 2015. Towards a new business history? Business History, 57: 5-29.

De Sombre, E.R. 2006. Flagging Standards: Globalization and Environmental, Safety, and Labor Regulations at Sea, Massachusetts \& London: Cambridge.

Dellacasa, A. 1987. Refrigerated transport by sea, Rev. Int. Froid, 10:349-352.

Donovan, A. and Bonney, J. 2006. The box that changed the world, Ubm Global trade.

Fagerfäll, R. 1999, Företagsledarnas århundrade. D. 3, 1967-200o: från Werthéns förvärvsstrategi till Barneviks globala nätverk, Stockholm: Norstedts.

Forsberg, P. 2001. Berättelser och omdömen i en redares vardag, Göteborg: BAS.

Gorter, D. 2012. Nederlaandse koopvaardijschepen in beeld - Seatrade, Alk B.V.

Gorter, D. 2014. Nederlandse koopvaardijschepen in beeld - Seatrade, part 2, Alk B.V.

Guy, E. 2013. Representations and policy change: evidence from the Canadian-flag shipping industry, Environment and Planning A, 45: 1184-1198.

Håkansson, H. and Snehota, I. 1989. No business is an island: The network concept of business strategy, Scandinavian Journal of Management, 5: 187-200.

Håkansson, H. and Snehota, I. (eds.). 1995. Developing relationships in business networks, London: Routledge.

Håkansson, H. and Waluszewski, A. 2002. Managing technological development-IKEA, the environment and technology, London: Routledge.

Harlaftis, G. 1996. A History of Greek-Owned Shipping. The Making of an International Tramp Fleet, 1830 to the present day, London: Routledge.

Hirahara, N. 2003. Distinguished Asian American Business Leaders, Westport: Greenwood.

Hillman Amy J., Michael C. Withers and Brian J. Collins, 2009. Resource Dependence Theory: A Review, Journal of Management, 35: 1404-1427.

Immerman, R.H. 1982. The cIA in Guatemala: The Foreign Policy of Intervention, Austin: University of Texas Press.

Jansson, C. 2012. Företag med framgång: hur resurser kan skapa varaktiga konkurrensfördelar, Göteborg: BAs.

Jarzabkowski, P. 2004. Strategy as Practice: Recursiveness, Adaptation, and Practicesin-Use, Organization Studies 25:529-560.

Jensen, L. 2014. Culture shock in Maersk Line - From Entrepreneurs and Kings to Modern Efficiency, Copenhagen: Vespucci Maritime Publishing.

Jephson, C. and Morgen, H. 2014. Creating Global Opportunities, Maersk Line in Containerisation 1973-2013, Cambridge: Cambridge University Press.

Jóhannesson, G.T. 2013. The History of Iceland, Greenwood: Santa Barbara. 
Kalling, T. 1999. Gaining competitive advantage through information technology - A resource-based approach to the creation and employment of strategic IT resources. Lund: Institutet för ekonomisk forskning, Lunds universitet.

Klose, A. 2015. The Container Principle, Massachussetts: MIT Press.

Kraaijenbrink, J., Spender, J-C. and Groen, A. 2010. A resource-based view: A review of and assessment of its critiques, Journal of management, 36: 349-372.

Kristensson Uggla, B. 2002. Slaget om verkligheten. Filosofi, Omvärldsanalys, Tolkning, Stockholm: Symposion.

Lange, O. 1995. Logbog for Lauritzen, Copenhagen: Handelshøjskolens forlag.

Lavie, D. 2006. The competitive advantage of interconnected firms: an extension of the resource-based view. Academy of Management Review 31: 638-58.

Lennerfors, T.T. 2009. Stockholmsrederierna - Ägandet och nätverkens betydelse för tanksjöfartens utveckling i Stockholm 1980-200o, Göteborg: Breakwater Publishing in collaboration with BAs.

Lennerfors, T.T. 2013. Att skapa en värld - Stena Bulk, Concordia Maritime och marknadsföringens betydelse i tanksjöfarten 1982-2012, Gothenburg: Breakwater Publishing in collaboration with BAs.

Lennerfors, T.T. 2014. An involuntary ship owner - the background and effects of Swedish state involvement in shipping during the 1970's and 1980's, International Journal of Maritime History, 26: 702-719.

Lennerfors, T.T. 2015. Eros, thymos, logos: A study of the spirit of entrepreneurship and innovation at Stena, Gothenburg: BAS.

Lennerfors, T.T. 2016. Elling Ellingsen - The Shipping Entrepreneur, Stockholm: Medströms.

Levinson, M. 2006. The Box: How the shipping container made the world smaller and the world economy bigger, Princeton: Princeton University Press

Lindström, A. and \& Malmberg, G. 2015. Svensk Sjöfartshistoria i storm och stiltje, Göteborg: Breakwater Publishing.

Lowe, N. and Hwang, K-S. 2012. A NICE agenda for IMP research, Industrial Marketing Management, 41: 706-714.

Malmberg, T. and Hag, E. 2013. Kalla Systrar från Åland på världens alla hav, Mariehamn: Stiftelsen Hilda och Gustaf Eriksons samt Gustaf Adolf Eriksons Understödsfond.

Manners-Bell, J. 2014. Global Logistics Strategies, London: Kogan Page

McKern, B. and Dunning, J.H. 1993. Transnational Corporations and the Exploitation of Natural Resources, Abingdon: Taylor \& Francis.

McCutcheon, C. 2010. Elders \& Fyffes: A photographic history, Gloucestershire:Amberley Publishing.

Müller, L., Hallén, P. and Lennerfors, T.T. 2016. Handel och sjöfart, in Ekström, S., Müller, L., and Nilson, T. 2016. Sjövägen till Sverige: Från 1500-talet till våra dagar, Malmö: Universus Academic Press, pp. 69-120. 
Neumann, P. and Somer, J.A. 2000. Reefership: The Art and Science of Supplying Fresh Produce to the world, Dole Fresh Fruit International.

Niemié, O. and Germain, O. 2014. Strategies in Shipping Industry. A Review of "Strategic Management" Papers in Academic Journals, Working paper, ESG/UQAM.

Niiya, B. (ed.). 2001. Encyclopedia of Japanese American History, Updated Edition. New York: Facts On File, Inc.

Nissui. 2012. A History of Hundred Years of Nippon Suisan Kaisha, Ltd., Available at: <http://www.nissui.co.jp/english/corporate/1ooyearsbook/pdf/10oyearsbook.pdf>. NYK. 1988. 日本郵船株式会社 100 年史 (Nippon Yusen Kabushiki Gaisha 100 Nenshi).

Oddy, D.J. 2007. The Growth of Britain's Refrigerated Meat Trade 1880-1939, The Mariner's Mirror, 93: 269-280.

Otten, J.M. 2005. Dammers \& van der Heide, Ridderkerk: JeMoTek.

Patriksson, F. narrated for Ulla Linton, 2012. Att kunna ta en storm, Gothenburg: Breakwater.

Pearson, M. and Lennon, J. Pastoral Australia: Fortunes, Failures and Hard Yakka: a Historical Overview 1788-1967, Collingwood: Csiro Publishing.

Peerbolte, H. (ed.). 1991. Seatrade 1951-1991, Groningen: Seatrade.

Penrose, E. 1959. The theory of the growth of the firm, New York: John Wiley \& Sons.

Perren, R. 2006. Taste, Trade and Technology: The Development of the International Meat Industry since 1840, Aldershot: Ashgate.

Pfeffer, J. and Salancik, G.R. 1978. The external control of organizations: A resource dependence perspective, New York: Harper \& Row.

Pfeffer, J. 1976. Beyond management and the worker: The institutional function of management, Academy of Management Review, 1: 36-46.

Plato. 2011. Phaedrus, Cambridge, UK: Cambridge University Press.

Poulsen, R.T. 2007. Liner shipping and Technological Innovation: Ostasiat and the Container Revolution, 1963-75, Scandinavian Economic History Review, 55: 83-100.

Priem, R. and Butler, J. 2001. Is the resource-based "view" a useful perspective for strategic management research? iAcademy of management review, 26: 22-40.

Read, R. 1986. The Banana Industry: Oligopoly and Barriers to Entry, in Casson, M. (ed.). Multinationals and World Trade, London: Allen \& Unwin, pp. 317-342.

Rinman, T. 1990. The Johnson Line 1890-1990, Gothenburg: Rinman \& Lindén.

Sinclair, J. et al. 1989. Refrigerated Containers, Technical paper. available at <http:// documents.worldbank.org/curated/en/618601468739777372/text/multi-page.txt>.

Sjöberg, S. 2007. Saléns: till rors i tre generationer, Stockholm: Salénia.

Sjögren, H. 1997. Spelet i Saléninvest, Stockholm: Ekerlid.

Soluri, J. 2005. Banana Cultures, Austin: University of Texas Press.

Stopford, M. 2009. Maritime Economics, New York: Routledge.

Taffrail, W. 1973. Blue Star Line at War, 1939-1945, London: Foulsham. 
Taylor, T. 2003. Evolution of the banana multinationals, in Josling, T.E. \& Taylor, T.G. Banana Wars: The Anatomy of a Trade Dispute, California: Institute for International Studies Stanford University, pp. 67-96.

Thanapolou, H. 2011. Bulk reefer market economics in a product life cycle perspective, Maritime Policy \& Management, 39: 281-296.

Theotokas, I. and Harlaftis, G. 2009. Leadership in World Shipping: Greek Family Firms in International Business, London: Palgrave Macmillan.

Thorsøe, S. 1984, J. Lauritzen 1884-1984, Gravesend: World Ship Society.

Todd, D. 1991. Industrial Dislocation: The Case of Global Shipbuilding, London and New York: Routledge.

Tolerton, N. 2008. Reefer Ships: The Ocean Princesses, Christchurch, NZ: Willsonscott Publishing.

Waters, R.C. 1993. Federal Regulations and the Competitiveness of U.S. Liner Ship Operators, Transportation Journal, 33: 53-58.

Whittington, R. 2006. Completing the Practice Turn in Organization Studies, Organization Studies, 27: 613-634.

Wijnolst, N. and Waals, F. 1999. Shipping Industry Structure, Delft: Delft University Press.

Wijnolst, N. and Wergeland, T. 2009. Shipping Innovation, Amsterdam: IOs. 


\section{Index}

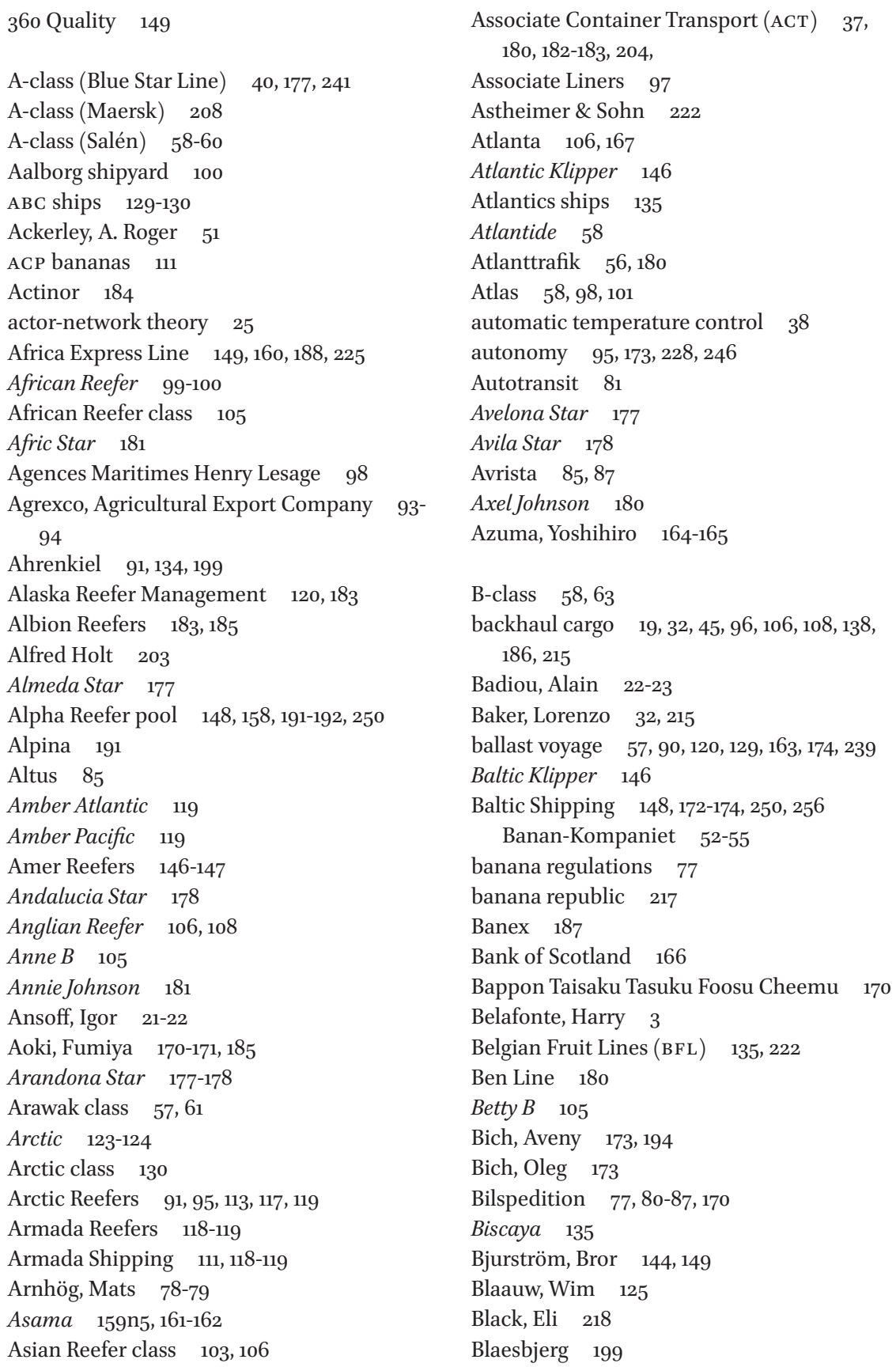


Blue Ocean $5^{6}$

Blue Star Line $\quad 5,32,36,40,106$, 171, chapter $8,199,204,235,241,249$

Bolero $\quad 58,62$

Booth Line $\quad 183$

Brazilian Reefer 100

breakbulk 6-7, 42, 62, 66, 94n34, 149

broker 20, 52, 73, 77-79, 96, 109, 123-124, 126, $143,157,159,168$, 190-191, 215, 255

Broströms 56

Bruns 199, 222

Bugge, Finn 105

Buitenwerf, Yntze $\quad$ 138, 146, 148, 193

bulk reefer 7,47

bunker 14, 40, 65, 70, 94, 105, 130, 137, 163, $187,190,243$

bus 20

Bylock, Lennart $\quad 83-84$

Bylock \& Nordsjöfrakt (B\&N) 84

C-class $\quad 186,188$

Cabana 222

Caesar Reefers $\quad 78-80,186,223$

Caledonia 52

California Fruit Canners Association 226

California Packing Corporation $\quad 226$

California Star 180

Capespan 77

Capital Finance 92

cargo liners 37, 179, 203

carnage $\quad 166$

Casablanca 135

Castle \& Cook 199, 221-222, 224

Cavendish $\quad 38,38 \mathrm{n} 26,221,240$

Ceiba 220

Chartworld 172

Chiquita 5, 32, 106, 111, 134, 136, 139, 164, 172, 214-219, 226, 231, 250, 256, see also United Fruit

Chr. Matthiesen 53

Citrus Marketing Board, Israel $\quad 230,230 n 45$

CMA CGM 150, 205-206

coaster 123, 134, 138, 155

cold chain $\quad 3-4$

cold store $\quad 6,32,54,67,142,144,176,195$

Collins, Sir John $\quad 183$

Colour class 149

Columbia Star 180
Columbus Line 198

Comité Interprofessionel Bananier

(Сів) 228

Comninos 103

Compagnie Fruitière 225

Companie Générale Transatlantique 98, 228

concentration 21

Concord 223

Confederation of Importers and Marketing Organisations in Europe of Fresh Fruit and Vegetables 43

consolidation $53,112,117,121,145,148,170$, $185,249,263$

containerization $7,37,45-47,80,150,155$, 168, 198, 204, chapter 10

container lines $\quad 7,17,20,44-45,47,48,90,91$, $114-115,145,149,187,194$, chapter 10, 230, 245-248

contract of affreightment, definition $\quad$ 16-18 control 15, 27, 144, 148, 229, 244, 246, 255, 257

conventional reefers $7,142,194,210,248$

Cool Carriers $\quad 5,58,110-112,119,121,137$, 143-144, 155, 165, 167, 169-170, chapter 4, 171-174

Copenhagen Reefers 118-119

Cornelis Vrolijk 127

cost leadership $\quad 21$

country class 219

crane $6,24,42,47,58,66,150-151,181,188$, 224

Crown type $\quad 19,168-169$

Crystal class 81

culture 114, 138, 175, 193, 243, 246, 250

Cunard 180, 183, 203

Cutrale-Safra 219

Cuyamel 33, 216

cyclical nature of shipping markets $\quad 86,254$

Daisansyugyosen $\quad 156$

Dammers, Jan 134-139

Dammers \& van der Heide $\quad 123-124,128,133$, 134-139, 155, 222, 245

Danish East Asiatic Company $\quad 180,210$

Danyard 107-109, 111, 218, 226, 256

David 145

Dawn group 91 
De Nadai 123,133

decline $27,173,194,198,248-250,259-260$, 262

Del Monte 184, 217, 226-228

dependence 20

deregulation 13, 114, 230

derrick $6,42,58,15^{1}$

differentiation 21

discourse $9,20,25-26,73,95,115,121,155$, 237, chapter 12, 258-26o

Discovery Bay 161

discursive turn $\quad 20,262$

diversification $\quad 21,59,86,159$

Dole $5,33,38,79,136-137,149,160,168-169$, 199, 220-225, 231, 247, 256, 261

Dole Chile 223

Dole Colombia 223

Dole Fresh Fruit International (DFFI) 223

Dole, Jim 222

door-to-door 91, 114, 173, 249

Doric Star 178

Doziadis, Dinos 190

Drammen shipyard $\quad 52,102-103,104 \mathrm{n} 7,255$

Dunedin 31

EA-series 135

East West Navigation $\quad 143,145,160$

Eastwind $\quad 89,164-166,172,191,246$

ECo Shipping 89-91, 95, 165

Ecuadorian Reefer 100

Egyptian Reefer 100

Eidesvik, Kristian 148, 151

Eimskip 194-195

Elders \& Fyffes $\quad 33,51,215^{-217}, 225$

Ellerman Lines $\quad 180,183$

Elliott, Frank 125

Emperor Penguin class 110

Empire ships $\quad 36,179$

employee union $\quad 159,161$

Enskilda Bank 54

Ericsson, Lars 184

Eriksberg shipyard $57 \mathrm{n} 7,5^{8}$

eros $23,27,237,239-240,244-245,248,260$, 261-262

ethnicity $27,137,242,250,259$

Europe West Indies Line (EWL) 146, 149

Evridiki 190

exchange rate 158,162 excitement 111, 121, 248, 261-262,

exit $93,94,117-119,145,157,171-173,185,192$, $243,246-247,251,256,260$

Exxon Valdez 86

Eystrasalt 172

Fafoutis, Nick 206

Fairfield Japan 164

Fairfield-Maxwell 163-164

fairness 18, 32, 103, 137, 254

Fairport 194

fairtrade $\quad 226$

Family class $\quad$ 107-113, 121, 244, 263

Far East Shipping Company (FESCO) 143, 165

Fedala 135

First World War 34, 51, 96, 177

Fiskö 39

Five, the $\quad 72-74,76-77,84-85,95,261$

focus 21

Francine 208

freezer $6,14,110,151,156,165,256,258$

Fresh Express 219

Fresh Fruit Carriers $\quad$ 160, 225

Fresh System 160

Frigorifique 31

Frigoship Chartering 191, 193

Frubel ships $135^{-13} 6,222$

Fyffes 225-226

Gato, Hector 129

Geest 111, 133, 225-226

Geestland 226

Geeststar 226

General Agreement on Tariffs and Trade $\quad 37$

Gersling, Boris 173

Ghazaleh, Abu 227

Girestad 88

Glen Line 203

Global Reefer Carriers $\quad 227$

Global Reefers 148

Godafoss 194

Golden gos $80,85,95,245$

grating $43,63,101,105$

Great American Lines 164

Great White Fleet (GWF) 77, 139, 214, 216, 218, 252

Green Reefers $\quad 53,146-148,151,193,250,256$ 
GreenSea Chartering $\quad 148,151,193$

Grete $9^{8}$

Gros Michel 38, 221

Gullfoss 194

Gustaf Erikson 39, 109-110, 196, 238, 252

Gusto Shipyard 135

Guttormsen, Thor Jørgen $\quad 92$

Gyllenhammar and partners $\quad 72$

Götaverken shipyard 66

Hamburg Reefer Chartering $\quad$ 147-148, 151, 193-194, 200, 255

Hamburg Süd 182-183, 188, 196-199

hands-on 93, 114, 138-139, 143, 155, 243, 245, 247,259

Hansen, Carsten $\quad 118$

Hapag-Lloyd 204

Haparangi class 36

Harding, Kevin 185

hardware $73,83,87,93-94,112$

Harland \& Wolff shipyard $\quad 181$

Harmstorf 191

Harr, Espen 53

Harvest class $\quad 168$

Hawaiian Pineapple Company 221

Heisler, Ira 163

Helga 98

Hirschler, Alex 163

Hispaniola 56, 59

Hitachi Zosen shipyard 157

Hokuriku Bank 162

Holland America Line 203

Holmfoss 195

Holy House $\quad$ 77-78

Honolulu class $136,139,146,222$

Horn 126, 199, 227

Hyundai shipyard 68

Höegh 84, 85, 86-94, 112-113, 246

Höegh Ugland Auto Liners 86, 90

Ice Cube building $\quad 138$

Ice Rose 120

Ikeda, $\mathrm{Mr} \quad$ 143, 159-16o, 162

Ikoma 161, 162

Imperial Direct West India Line $\quad$ 33, 225

Inca class 135

independent reefer operator $5,17-20$, chapters 3-9
ING Bank 147, 162

Intercontinental Transportation Services

(ITS) 222

International Reefer Services 109

Irgens Larsen 184, 222

Ishikawa, Hiroshi $\quad$ 169-170

Ishise, $\mathrm{Mr} \quad 157$

Italian Reefer series $\quad 38,101,105,241$

J.S. Hamilton 124

Jaczon 127,133

Jaffa 98,230 n 45

Jamaica Producers 133

Jan Willem 136

Janholt, Torben $\quad 112,118$

Jansen, Mark 138-139, 149

Jansson, Bill 184

Jansson, Christer 184

Jansson, Mats $87-88,92,113-115,117,155,173$, 248-249

Japan Reefer Carrier 166-167

Java Pacific Line 86

Jedeur-Palmgren, Peter 144

John Morell meatpacking company 218

Johnson Line $\quad$ 180-181, 204

Joint Fruit Co $\quad$ 146, 186

Joint Trawlers 127

Jumbo class $\quad$ 105-106, 108-110, 118-119, 244

Kalborg, Ted 87

Kallsö 110

Kawasaki Kisen Kaisha, K-Line $\quad$ 167, 207

Keith, Minor $\quad$ 32, 214-215

KESC 68

Kirkebye, A.W. 97

Kirkebye, Lillian 97

Kitanihon shipyard $\quad$ 143, 146

Klaipeda Shipping $\quad 165,173,191,194$

Klaveness $\quad 52-53,184$

Klaveness, Torvald $\quad 5^{2}$

Klenell, Thorsten $\quad$ 128, 144

Kockum shipyard 66

Kommanditgesellschaft (KG) $\quad 145$

Korf Shipping 165

Kosan Tankers 111

Kousi, John $\quad$ 90, 164

Koyo Dockyard 68

Kvaerner Kleven shipyard $\quad$ 110, 218 
Kyknos I 190

Kyokuyo, KY 119, 157-159

Køge shipyard 96

language $\quad 9,23,25,61,142,159$

Larsson, Christian $\quad 77-78$

Larsson, Håkan 85

Larsson, Lars-Gunnar 144, 170

Laskaridis group $133,161,173,190-195$, 199-200

Laskaridis, Constantine 190

Laskaridis, Panos 190

Laskaridis, Thanassis 190,260

Laura Christina class 135

Lauritzen $\quad 5,36,38,53,58,69,71,83,94$, chapter $5,145,173,184,188,208,235,236$, 237-250, 253-262

LauritzenCool 112-120, 149, 171, 175, 185, 249

LauritzenCool Logistics (LCL) 114, 171, 173, $249,25^{\circ}$

Lauritzen, Ditlev 96, 236

Lauritzen, Ivar 97-98, 104

Lauritzen, Knud 97-98, 104

Lauritzen, Ole 107

Lauritzen Peninsular Reefers (LPR) 102-104, 106, 120, 181, 241-243

Lavinia $\quad 133,148,161,192-194$

Lenin shipyard 78,223

Lente, C. 123

Leo Polaris 126

Leonina $\quad 75,85,167,173,198$

Lev, Daniel 165

liberalization 43

Limarko 194, see also Klaipeda

Lindberg Skov, Birger 113

Lindner, Carl Jr 218-219

liner company $5,9,37,39,87,102,128,180$, 199, chapter 10, 231-232, 236-240, 247, 249, 252, 257-259, 263

liner conference $\quad 40,48,62,203-204,207$, $236,238,253$

liner gap 48,240

locus of strategy $\quad 21,93,173,250,253,255$

logos $23,27-28,235,241,244,250,260$

loyalty 144

Lundberg, Martin $\quad 80,82,83,85$

Lund, Mike 111
Mad Cow Disease $\quad 182$

Maersk 5, 20, 92, 100, 166, 205, 207-212

Maersk Container Industries (MCI) 150, 210

Maersk-Sealand 210

Maestro Reefers $\quad 119-120$

MargaretJohnson $\quad 181$

Marine Chartering Co (MCC) 135

Maritima del Norte $\quad 146,192$

Maritime Fruit Carriers (MFC) 64-66, 222, 242

Maritime Reefer Agency 173

marketing board 43, 169, 228-231

Maruha Taiyou Gyogyo, Maruha 156, 159, 162-164

materiality $9,23-25,115,25^{2-25} 8,262$

Matthiessen, Carl $\quad 51-52,56$

Matthiessen, Christian $\quad 5^{1-52}$

McKinsey $\quad 68,71,83,106-107$

Mediteranska Plovidba, Medplov 91

Mediterranean Shipping 205, 212

Meiggs, Henry 214

Mermaid class 168

Mico, Margaret 124

Mico, Miguel 124

Mitsui osk Line 167, 207

Moors, Toby 89,165

MPC Münchmeyer Petersen Steamship $\quad$ 145, 147,186

MSC 20, 205

multi-pallet loader $\quad 42,66$

Musterd, Erik $\quad 133,137,142$

N-type $\quad 128,130-131,133$

Naesvang, Torben 111, 118

Nagaki, Mr 16o, 168

Nakabe family $\quad 163$

Natt och Dag, Bo 81

Nautic 131

Nedlloyd 136, 139, 183

network 20, 22, 24, 157

Network Shipping $\quad 227$

New Zealand Apple and Pear Marketing Board 230

New Zealand Dairy Board 228

New Zealand Meat Producers Board $\quad 228$

New Zealand Shipping Company 36

newcomer $\quad 65,71,89,109,175,249,259$

Nichiro Gyogyo 157-158 
Nieuwe Noord Nederlandse Scheepswerven $123,130,135-136$

Nilsson, Jerker 119

Nilsson, Lars 144

Nipponkai Heavy Industries $\quad 161$

Nissen Kaiun $\quad$ 186, 188

Nissui, Nippon Suisan $\quad 36,143,145,157$, 159-162, 175, 245

Noboa 90, 108, 111, 231

Nomadic Shipping $\quad 147,151$

Nordea bank 166

Norén, Gösta 144

Normandic 131-132

North German Lloyd 203

Northern reefer class 81

NYK, NYK Reefer $\quad 85,158-159,161,166-173,175$, $183,185,197,207,223,246,247,249$

NYKCool $78,171-173,219,249-250$

NYKStar $170-171,185,249,255$

Ocean Reefer Services (broker) 53

Oceanic 129

OCL $\quad 37,204$

Odfjell 151

Ödner, Sture $\quad 60,64-65$

Oetker $80,186,196$

offshore 104, 107, 111, 145

Ohno, Ken-nosuke 160-161

Ohno, Sadaya 161-162

oil crises 40, 43, 48, 65-66, 70, 218, 243, 253

Old Mutual 92

Olsson, Christer $\quad 170$

Olszowski, Andrew 124

Olympic International 164

open hatch ships $42,66,68,73$

Orion (broker) 53

Orion class 168

Orsero-Fruttital/Simba 128, 133

Osterreichischer Lloyd 91

Oteri brothers 220

Outspan 87-88, 105

Oweson, Per-Olof 77,110

ownership $8,17,73-74,76-77,79-80,83,85$, $88,92,114,121,244,246,253-254$

Oyen, Peter 53

P\&O 102-103, 170-171, 183, 203-204, 243

P\&O Nedlloyd 183,210
Pacific 124

Pacific Express Container Line 183

Pacific Sea Highways (Psw), Pacific Seaways 148, 164

Pallcon ships $\quad 92,117$

pallet height 43

palletization $6,39,42-43,62-63$,

Panama Disease $\quad 35,38,216,220,240$

Paraguay 31

parcel-service 129, 133

Parlevliet \& Van der Plas 127

part-reefer $6,31,135,236$

passenger liner $33,37,177,203$

Patriksson, Folke $83-84$

Penguin class 110

Pepping, Geert (Gerry) 127-128, 130, 132-133, 136-137, 146-147, 16o, $25^{\circ}$

Pepping, Hendrik 135-136

Percal 76

Perfresh 76-77, 78,

perishability $3,114,231,237-238,254,258$

Pescanova 124

Phoenix class 146,168

Pinkster Shipping 123

Plato 23, 27

Plaza Accord 161, 168

Ploughman, Dale 137, 139, 218

Polar Shipping 199

Polly Peck International 227

pool 17-18, 75, 81, 83, 123, 125, 133-134, 137, 145, $147,151,165,185,191,255$,

Port Morant 33, 225

Porter, Michael 21-22

porthole containers $37,181,204,209$

prestige $27,106,109,139,143,165,199$, $245^{-247}$

pride $27-28,90,95,108,110,113,155,160,200$, 236-237, 240-241, 243, 246-247, 260-261

Primlaks 133, 190,

Prince type 118-119

privatization 43

Project Ship 107

Protectionism 111

psychology 9, 27-28, 26o-262

Puritan class 218

quality $3,15,22,25,33,58,93,117,125,149$, $186,192,236,237,239-240,244,246$,

249-250, 259 


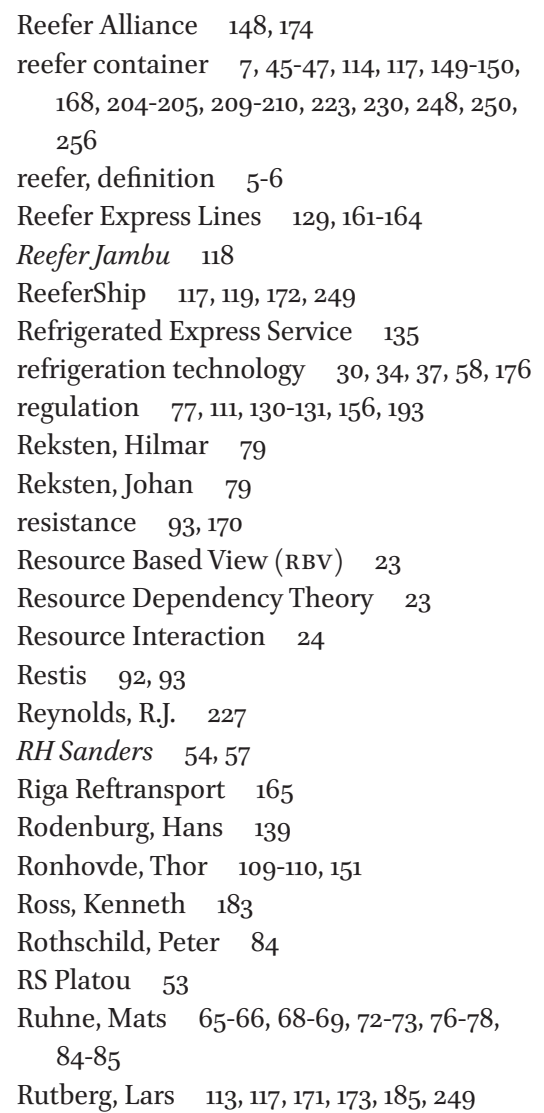

Saetre, Morten 53

Safmarine $87-89,92,93,210$

Salén $5,38-40,43$, chapter 3, 214, 217-218, 221, 229, 235-243, 247, 252, 254-256, 259-261

Salén Reefer Services (SRS) 61-72, 102,

Salén Supporters 72

Salén, Christer $\quad 60,72-73,84$

Salén, Sven $\quad 51^{-56}, 58,60,235,237$

Salén, Sven Hampus $\quad 60,72$

San Benito $\quad$ 58-59

San-series $\quad 5^{8-59}$

Sandhamn $\quad 55-57$

Santa Catharina 162

Saptari 173

Sasebo shipyard $\quad 164$

Satsumaru Kaiun $\quad 167$

Saudi Arabian Company $\quad 105$

Scaldis Reefer Chartering 142
ScanStar 180

scheduling, computerized $\quad 62,241$

Scheepswerven v/h Gebr. Van Diepen 130132

Scheepvaartkantoor Groningen (SKG) $125,135,145$,

Schenker-BTL 85

Schuur, E.H. $\quad 123,126-127,145$

Schuur, Henk $\quad$ 127-128, 130, 132, 142

Sea Containers 67

Sea-Land 207

Seatrade 5, 53, chapter 6, 160, 162, 171, 174-175, 182, 190, 192-193, 199, 225, 242, 243, 245-251, 253, 255-256, 259-262

Seatrade Orange 149, 150, 225

Second World War $36,38,55,79,100,122$, $156,162,177-178,217,220,235,237,239$

Securities and Exchange Commission $\quad 218$

Selling, Glenn 89

Sembawang shipyard $\quad 103,105$

sense-making $\quad 22-23,25$

Seven Hills $\quad$ 172-173

shark's teeth 102-103, 121, 241

Shikoku Yard 157, 186, 188, 256

Shin Kurushima shipyard $\quad 164$

ship-owner $8,14-19,55,75,78-79,88,161,261$

shipbuilding subsidies $\quad 40,64,137$

shipper $5,10-14$, chapter 11

Shrine type 157

side-loader $\quad 47,92,117-118$

Siem Car Carriers $\quad 188$

Siem, Christian $\quad 145,171,184-185,188-189$, 249, 259

Siem Industries $\quad 176,184,188$

Sigatoka (disease) 35, 216, 220

Sigrid Matthiesen 53-54

Silver Sea $\quad 151$

Simmons, Don 164

Skou, Soren $\quad 210,212$

Smits 199

Snow class $\quad 40,43,63-66,77,101,181,243$

Snow Flake 64

Snow Flower 64

Snow Land 64

software $73,83,85,87-88,93-94,112$

Solidarity movement $\quad 78$

Sorus 173

South Africa Deciduous Fruit Board 105 
Sovfracht 229

Soviet Union, collapse of $13,44,165,191$, 230

Soyuzplodoimport 229

specialized reefer, definition 7

speed $\quad 6,26,38-40,239,241$

Split shipyard $\quad 91$

Spring class $\quad 68-69,73,81,136-137$

SRS reefer $\quad$ 72-75

Stal $5^{8}$

Standard Fruit $\quad 32-33,67,136,197,216-217$, 220,227

Star Courage 188

Star Endeavour $\quad 187$

Star First class $\quad 186,188$

Star Reefers 121, 170, chapter 8, 192, 199-200, 223-225, 228, 231, 249-250

Star Spirit 188

Stenbeck, Jan $\quad 72,76-77$

stereotypes $65,250,259$

Stinnes 85

Stockholms Frihamn 54

strategy as practice $\quad 25$

strategy, theory of $8,10-20$

StreamLines 148

subjective dimension $\quad 22-28,90$, chapter 12 , 260-262

Sugahara, Bryan 163

Sugahara, Byron 163-164

Sugahara, Kay 162-163

Sumitomo 119

Sunbelt Dixie $\quad 164,166$

Sunbelt Spirit $\quad 164$

Sunkist $39,60,62,64,66,240$

Sunway 186

supermarket $3,43,182,230,246,258,263$

Sverre Nergaard 53

Swan Reefers $\quad 145,176,183-185,188$

Swedish Lloyd $\quad 97-98$

Swedish state $66,73,76$

Takeko, $\mathrm{Mr} \quad 161$

Tama Ace $\quad 161$

Tamiya, Michio/Mitch $\quad$ 167-171,173

Tammes, J. $\quad 123$

Tammes, Kees 123, 127

Tammes, R.T. 123

Tammes, Tom $\quad$ 123-128, 142 tanker $38,60,65,66,70,79,86,101,105,111$, 121, 166

tax $15,142,183,196$

taxi 20,258

Teтpo 124

Thoen, Aage $\quad 171,185$

Thomassen, Alv 53

Thorstad, Nils $\quad 125-126$

thymos 23, 27, 236, 241, 244-246, 248-249, 260-261

Tijger 134

timecharter, definition $\quad 16$

timecharter rates $\quad 47-48$

Toei Shipping 160-162

Tokumaru Kaiun 91, 167

Tokyo Reefer Chartering $\quad$ 145, 160

Tom van der Heide 135

Tonnevold, Jan Olaf 53

Tor Line 82

Torm 100

Touei Maru 161

Tоиуи Maru 161

Toyota 164

Toyota Way 91

tramp shipping, definition $\quad 203$

Trans Ocean 165

Transal 60

Transatlantic 60,180

transshipment $\quad 4,39,190-191,194,256$

trawler $36,59,126-127,156,194$

Trelleborgs 56

Triton 146

Tropical Trading and Transport

Company 215

trust $57,74,77,148,254,259$

Tsuneishi shipyard 105

Tufton Oceanic $\quad 85,87$

Ugland 86,170

Ulla 98

Ulsan shipyard 224

UN exclusive economic zone $\quad 156,174,190$

Uniban $\quad 75,226$

Unicool $\quad 88-93$

Unifruco $\quad 87-88$

Union International $\quad 182-183$

United Brands 59, 65, 67, 69, 159, 218, 227, 261, see also United Fruit 
United Fruit $\quad 32-33,38$, 51-52, 56-59, 62-65, 172, 214-219, 220-221, 223, 225, 226-227, 229, $231,236-238$

United Reefers $\quad 145,171,183$

Universal Reefers $\quad 87-88,167,170$

Vaccaro brothers $\quad 32,220$

Valley class 181

Van den Brink, Jan $\quad 76$

Van der Heide, Antonius Wilhelmus 134

Van Geest, Jon 226

Van Geest, Leonard $\quad 226$

Van Overklift, Marnix 124-130, 142-143, 146-147

Veder, Anthony $\quad$ 118, 135

ventilated fruit carriers $32,36,53,98,216,220$, $231,236,256$

Venus 33, 216

Vesterhavet 96

Vestey, Edmund Hoyle 183

Vestey, Samuel 176

Vesteys $32,176-177,182-183,185,235$

Von Platen, Henrik 105

Von Reiche, Joachim 191-193, 198-199

Vostokrybkholodflot $\quad 165$

Vroon $132-133,137,145,183$

W. van der Zwan $\quad 127$
Wallenberg, Jacob 54

Wallenius 170

Walmart 13, 43

Wałęsa, Lech $\quad 78$

Weitemeyer, Peter 110

Wellington Star 179

West Africa Line 86

White Star 203

Wild class $\quad 169$

wild reefers 103, 237-240

Wildöer, Walter $\quad 138,144$

Winter class $66,68,76,83-84,105,242^{-}$ 243

WISIDA 110

Yakubenko, Sergei 165

Yamato Reefer 157

Yangfan Group 149

Ygrybtranssbyt $\quad 165$

Yoro 220

Zenit $\quad 76$

Zephyros 190

Zerkani, Shereen 212

Zespri 160, 229-230, 258

Zethelius, Claes-Henrik $\quad$ 62, 66

Zielke, Wolfgang $\quad$ 193, 199

Zodiac $\quad$ 91, 146 